\title{
Praksisnær undervisning - i praksis og teori
}

Yngve Troye Nordkvelle, Lene Nyhus, Anne Røisehagen og Randi Hojem Røthe (red.) 


\section{Praksisnær undervisning - i praksis og teori}



Yngve Troye Nordkvelle, Lene Nyhus,

Anne Røisehagen og Randi Hojem Røthe (red.)

\section{Praksisnær}

undervisning -

i praksis og teori 
(C) 2020 Yngve Troye Nordkvelle, Lene Nyhus, Anne Røisehagen, Randi Hojem Røthe, Inger Marie Bakke, Egil Eide, Håkon Glommen Eriksen, Trine Fossland, Grete Salicath Halvorsen, Gisle Heimly, Thomas de Lange, Monika Nerland, Eli Skjeseth, Odd Rune Stalheim, Njål Vidar Traavik, Ingrid Tvete, Anne-Lise With og Anne Line Wittek.

Dette verket omfattes av bestemmelsene i Lov om opphavsretten til åndsverk m.v. av 1961. Verket utgis Open Access under betingelsene i Creative Commons-lisensen CC-BY 4.0 (http://creativecommons.org/licenses/by/4.0/). Denne tillater tredjepart å kopiere, distribuere og spre verket i hvilket som helst medium eller format, og å remixe, endre, og bygge videre på materialet til et hvilket som helst formål, inkludert kommersielle, under betingelse av at korrekt kreditering og en lenke til lisensen er oppgitt, og at man indikerer om endringer er blitt gjort. Tredjepart kan gjøre dette på enhver rimelig måte, men uten at det kan forstås slik at lisensgiver bifaller tredjepart eller tredjeparts bruk av verket.

Boka er utgitt med støtte fra Høgskolen i Innlandet og Høgskulen på Vestlandet.

ISBN trykt bok: 978-82-02-67232-4

ISBN PDF: 978-82-02-63258-8

ISBN EPUB: 978-82-02-67551-6

ISBN HTML: 978-82-02-67552-3

ISBN XML: 978-82-02-67553-0

DOI: https://doi.org/10.23865/noasp.94

Cappelen Damm Akademisk/NOASP

noasp@cappelendamm.no

Omslagsdesign: Cappelen Damm AS 


\section{Innhold}

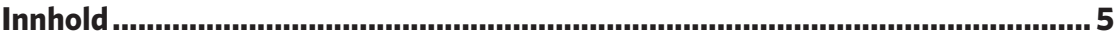

Kapittel 1 Praksisnær undervisning - nytt begrep og ny realitet? ................... 7 Yngve Nordkvelle

Kapittel 2 Hva kan praksisnær undervisning være? 33

Grete Salicath Halvorsen

Kapittel 3 Psykologisk kontrakt med studenter i høyere utdanning 53 Gisle Heimly, Egil Eide og Njål Vidar Traavik

Kapittel 4 Veiledningssamtale for første års studenter: Et innspill til praksisnærhet og studiekvalitet. 67 Anne-Lise With

Kapittel 5 Seminar som undervisningsform i høgere utdanning 81 Anne Røisehagen

Kapittel 6 Praksisnær undervisning med simulering og rollespill 99 Yngve Nordkvelle, Odd Rune Stalheim, Trine Fossland, Thomas de Lange, Line Wittek og Monika Bærøe Nerland

Kapittel 7 A skrive om hendelser fra egen praksis 121 Eli Skjeseth

Kapittel 8 Å lære om seg selv gjennom å observere andre. 141 Inger Marie Bakke, Håkon Glommen Eriksen og Lene Nyhus

Kapittel 9 Feltarbeid - forskande tilnærming til praksis .161 Njål Vidar Traavik, Egil Eide og Gisle Heimly

Kapittel 10 En dags praksis: Hvordan bidra til at studentene finner sammenhengen mellom teori og den virkelige verden? 179

Randi Hojem Røthe 
Kapittel 11 Praksisnær undervisning - en forutsetning for innovasjon og entreprenørskap! Ingrid Tvete

Om forfatterne 


\title{
KAPITTEL 1
}

\section{Praksisnær undervisning - nytt begrep og ny realitet?}

\author{
Yngve Nordkvelle \\ Høgskolen i Innlandet
}

\begin{abstract}
The task of mediating meanings of what may be constituted as 'practice' and 'theory' - its differences of kind and essence - and their commonalities or unions in the everyday of students - and the professions they are being prepared for, is demanding. The introductory chapter seeks to introduce a multitude of angels to view the phenomenon by. There is a political angle about how we make students better prepared for their future vocational contribution to the society, so that their human capital is realised as soon as possible in the knowledge economy. The humanistic angle suggested in the chapter deals with the personal and social development of the students. There is also a philosophical angle available to interprete how thinking and reasoning is a matter of shifting modes with acting and doing - and reflecting on the relations between them. The chapter uses the framework adapted from Ernest Boyer to project where we as academics are in the landscape of higher education: in the disciplines or in education of professionals.
\end{abstract}

Keywords: philosophy of knowledge, sociology of knowledge, scholars, academic drift

\section{Introduksjon}

Praksisnærhet er et nytt fyndord i høyere utdanning. En rekke offentlige utredninger sier vi bør drive praksisnær forsknings- og utviklingsvirksomhet. De samme dokumenter sier vi bør drive forskningsbasert undervisning.

I denne boka forsøker vi å beskrive undervisningsformer som forener de to, slik at forskningsbasert undervisning forankres i en praksisnær forsknings- og utviklingstradisjon.

Sitering av denne artikkelen: Nordkvelle, Y. (2020). Praksisnær undervisning - nytt begrep og ny realitet? I Y. T. Nordkvelle, L. Nyhus, A. Røisehagen og R. H. Røthe (Red.), Praksisnær undervisning - i praksis og teori (Kap. 1, s. 7-31). Oslo: Cappelen Damm Akademisk. https://doi.org/10.23865/noasp.94.ch1.

Lisens: CC BY 4.0. 
Boka bygger på et perspektiv som er kritisk til et syn på forskning som noe eksklusivt som bare folk ved universiteter og høgskoler driver på med. Nyere perspektiver på hvordan ny viten oppstår, har en bred utsikt mot en lang rekke institusjoner som driver innovasjon og entreprenørskap i sine bransjer og foretak. Forskningspolitisk har Norges forskningsråd gjennom mange år søkt å trekke inn brukere og praktikere i å utforme forskningsspørsmål, og å få praktikere og forskere til å arbeide sammen. Dette er like aktuelt i ulike fag enten det gjelder økonomi og matematikk eller disiplin- og profesjonsfag.

Yrkesutdanningsfag eller profesjonsutdanninger har opplagte muligheter til å være nær på den praktiske yrkesvirkeligheten i utdanningen. I sykepleierutdanningen skal halvparten av studietida foregå i praksismodus. I film- og tv-studier og kunstutdanninger foregår opplæring som en systematisk oppøving i å utføre faget, og suksessen måles i hvor lett studentene går over i yrker uten videre utdanning og tilpasning. I dansk høyere utdanning spiller forberedelse for yrkeslivet en stor rolle for finansiering av institusjonene, og liknende forslag er kommet for norsk utdanning. I disiplinfag er det vanskeligere å finne opplagte tangeringspunkter med en gitt yrkespraksis.

Uansett har de aller fleste studier en viktig oppgave med å utforme sine arbeidsmåter og undervisningsformer slik at de oppleves som relevante og troverdige som forberedelse for et arbeidsliv. Sykepleierstudenter som ferdes mye i sykehjem og sykehus og bærer sine uniformer og studerer sitt fag i tett samarbeid med profesjonelle yrkesutøvere, kan synes å ha en lett overgang til yrkeslivet. Det samme kan man si om lærerstudenter og medisinere. Det virker likevel ikke slik at disse praksisnære studieformene har løst problemet med at studenter faller fra i løpet av studiet og etter nokså kort tid i arbeid.

Praksissjokk er betegnelsen på en av de opplevelsene studenter kan få i overgangen til yrkeslivet, og i lærerutdanningen er det etablert støtteordninger for nyansatte lærere som er mest nærliggende ofre for sjokket. Praksissjokket er imidlertid en realitet i svært mange grupper av utdanninger, også der studentene får en mer generell utdanning som kan resultere i en rekke former for yrker enten det gjelder konsulenter for for eksempel Jernbaneverk, NSB, Vegvesenet eller treningssentre. 
I Mjøsutvalgets innstilling tilbake ved årtusenskiftet (Mjøs et al., 200o) lå det en klar forventning om at studier skulle gjøres mer yrkesrelevante. En del av forventningen om dette lå i den vekten underveisvurdering og tilbakemeldingspraksis skulle ha. Tanken var at studentene skulle få tettere kontakt med lærerne og at veiledningsdialoger og formativ vurdering skulle koble studentene nærmere på det sett av forventninger de skulle komme til å møte i arbeidslivet. Tidligere var studiene organisert slik at studentene fikk svært få tilbakemeldinger, og som regel kun i form av karakterangivelser. En annen komponent i Mjøsutvalgets innstilling var den økte vekten på problemorienterte studier og studentaktiv undervisning. Gjennom å trekke inn eksempler og konkrete «case» var intensjonen å gjøre studentene mer engasjert med det virkelige liv enn hva som var tilfellet tidligere. Jus, medisin og odontologi ble foregangsmiljøer i å bygge slike studier som problembaserte studier, der studentenes oppdagelser av problemer, som dominerer yrkets hverdag, settes i fokus.

\section{Praksisnær - nærmere praksis enn teori?}

Vi som skriver i denne boka har tatt utgangspunkt $i$ at praksis er det livet vi lever i den virkeligheten vi observerer og tolker som best vi kan. Reformene i høyere utdanning de siste tiår kan sies å ha en ambisjon om å minske avstanden mellom de høyreiste utsiktstårn ved universitetene og den hverdag som folk flest lever i. Reformene i vårt land er i takt med reformer $\mathrm{i}$ andre land. Mjøsutvalgets utredning fra 2000 var i mange måter en refleks av den engelske «Dearing-report» (Higher Education in the learning society, 1997) med mange likhetspunkter.

Spørsmålet om nærhet og distanse har imidlertid en lang forhistorie i de fleste lands høyere utdanning. Typisk er at Universitetet i Oslo i mange år drev såkalte embetsstudier også for fag mange oppfattet som disiplinfag. Eksempler er fag som samfunnsøkonomi, psykologi, sosiologi og pedagogikk. I disse studiene var det obligatorisk med praksis i virksomheter med psykologi, sosiologi eller pedagogikk som klinisk aktivitet. Teologer har helt siden 1848 tatt et tillegg ved Universitetet i Oslo som ble kalt praktisk-teologisk seminar som forberedelse på prestegjerningen. Filologer og realister som ønsket tilleggsutdanning for å bli lærere, måtte 
ta pedagogisk seminar. Det er en viktig erfaring i seg selv at praktiske komponenter i studier ofte ble sett på som noe som besudlet de teoretiske studiene. Hvis de skulle studeres, måtte det foregå i laboratorier på lærestedet. Et eksempel fra lærerutdanningen kan vise hvor stor avstanden har vært: Pedagogen Erling Kristvik ønsket å finne ut mer om hvordan praksisundervisningen for lærerstudenter foregikk, og søkte Stortinget i 1923 om tillatelse til å ha faste observasjonstimer i øvingsskolen. Det ble avslått. Praksisnærhet har altså ingen udelt positiv valør i vår utdanningshistorie. I dag er dette snudd helt på hodet (Solstad, 2010).

Rekrutteringen til undervisningsstillinger i akademia kom i stor grad fra yrkeslivet. Lærerutdanningen rekrutterte mange prester, og realfagslærere og språklærere i gymnaset rykket inn i universitetene. Tannleger og leger var selvsagte støttespillere til medisinerutdanningen og odontologiske studier. Foreningen av vitenskapelige tjenestemenn ved $\mathrm{UiO}$ ønsket universitetslektorene velkommen som medlemmer fra 1947 av. Da stillingen universitetslektor fikk sin opprykkstittel - førstelektor - på 1950-tallet, var dette et resultat av at mange dyktige lektorer gjorde arbeid som ble vel ansett og som fordret anerkjennelse og karrierestige. Mange av dem var begynt å forske og arbeidet med FoU-oppgaver i det daglige slik at skillet mellom dem som kom inn med en forskerbakgrunn bygd på en magistergrad eller hovedfag alene, og dem som hadde undervisningsbakgrunn i tillegg, var utydelig. Midt på 1950-tallet ble ordningen med at man kunne søke om opprykk ved å vise til kvalifisering, innført ved Universitetet i Oslo. Motstanderne av dette mente at mange vil «forsømme undervisning og annet instituttarbeid ...» (Nilsen, 2005, s. 79) om de skulle kvalifisere seg. Skillet mellom den konvensjonelle forskeren i en såkalt kombinert stilling og de som primært formidlet forskning gjennom undervisning og veiledning, ble tydelig markert med separate karriereveier: amanuensis og førsteamanuensis i motsetning til universitetslektoren - og førstelektoren.

I 1955 ble ordningen med at doktorgraden ga opprykk til førstestillinger innført. Før dette var det kun individuell kompetanse mellom meritterte søkere som gjaldt, og det var instituttbestyreren som vurderte søkerne. For de som ikke strevet etter en doktorgrad, men som mer enn før måtte ta seg av undervisning og annet instituttarbeid, ble det innført 
en førstelektorstilling. Komiteen som ledet arbeidet, var en professor i historie, Sverre Steen, som var viden kjent for å være en ualminnelig akademiker. Hans engasjement for arbeiderbevegelsens historie, for sosial rettferd og aktelse for de manuelle yrker ble også uttrykt gjennom hans formidlingsarbeid, som forfatter og underviser (Nielsen, 2005, s. 70). I sin samtid ble han sett på som en akademiker som var meget folkelig og som åpnet for en kritisk debatt om hva akademisering innebar.

\section{Utdanningers «akademisering»}

Akademisering av studier i høyere utdanning er med andre ord et kontroversielt tema gjennom historien. I viktige historiske perioder var universitetene som institusjon svært preget av «Erasmus Montanus»-liknende personligheter, som Ludvig Holberg beskrev med skarp penn. Universitetet i Göttingen i Tyskland, som ble etablert i 1734, brøt med tradisjonene om å ansette venners venner, svigersønner og svogre og heller ansatte lærere med ry som talere og lærere. De skapte en helt ny akademisk kultur der studenter og lærere med folkelig appell fikk stor innflytelse. Det var her Wilhelm von Humboldt (1767-1835) ble inspirert til å utforme sine prinsipper om forskningens fordomsfrihet og sammenhengen mellom undervisning og forskning. Fornyelsen vi forbinder med akademisering innen den humboldtske universitetsfilosofien, har to sider. Den ene handler om å frigjøre seg fra tyngende tradisjoner (som kameraderi og nepotisme) og knugende verdier og interesser fra samfunnets side. Den andre handler om å hente inspirasjon fra studenter og omverdenen og samfunnslivet for å inkludere folk flest sine synspunkter i det akademiske.

Denne tosidigheten i akademisering ser vi at Universitets- og høgskolerådet kommenterer i beskrivelsen av førstelektorstillingen. På den ene siden sier den i sine veiledende retningslinjer at doktorgraden er normen for førstestilling i den akademiske leia, mens førstelektorens kvalifisering ikke skal innebære akademisering ${ }^{1}$. Sett fra et kritisk synspunkt blir akademiseringen oftest sett på som en nødvendig følge av akademias søken etter ære, status og lønn, ettersom publisering, tellekantsystem og

1 http://www.uhr.no/documents/Endelig_versj_veiledn_forstelektoropprykk.pdf 
professortitler er de viktigste symbolene på dette (Thue, 2017). Dersom et akademisk miljø utvikler sekteriske posisjoner, eller overteoretiserer på måter som praktikere ikke lenger ser relevant, har den akademiske driften tatt overhånd, hevder Osland (2017). Akademiseringens kjennetegn, eller den akademiske drift, som den også kalles, synes å være akseptert som forenlig med de lange profesjonsutdanningene som jus, medisin, odontologi, men blir sterkere kritisert innen de kortere - eller semiprofesjonelle - fagområdene som helse- og sosialstudier og lærerutdanning (Osland, 2017). I disse utdanningene er det et stort behov for lærere som realiserer den andre formen for akademisering - eller den godartede akademisering, om en vil. Det er nok denne andre «driften» vi ønsker å bidra til i denne boka.

Sjøl om norsk høyere utdanning siden 1970-tallet har blitt trukket stadig nærmere universitetenes funksjon og virkemåte, har den ikke helt og holdent havnet i den skadelige akademisk drift, ifølge Messel og Smeby (2017). Som Stjernøutvalget pekte på, er høgskoler med universitetsambisjoner blitt ivrige på å sette forskningsbasert undervisning høyt på dagsordenen, og de er blitt mer universitetslike med vekt på professortitler og publiseringsvolum. På den annen side er universitetene blitt mer opptatt av å gjøre sine studier mer praksisrelevante. Ifølge Messel og Smeby (2017) har vi fått en praksisrettet akademisering. Det er dette fenomenet som trenger beskrivelser og ideer for videre utvikling.

Pendlingen mellom akademisering og praksisnærhet kan illustreres av en reform i amerikansk høyere utdanning. Rundt 1910 ble amerikansk medisinerutdanning lagt under lupen av en kommisjon satt ned av den amerikanske medisinerforeningen (Hiatt \& Stockton, 2003). Carnegieinstituttet for fremming av god utdanning fikk oppdraget, ledet av skolemannen Abraham Flexner. På den tiden eksisterte det 155 institusjoner i USA som utdannet leger. Etter Flexners rapport ble antallet redusert til 66 fram til 1935, og institusjonene ble underlagt et universitet, og vitenskapeliggjort med krav til lærere som forsket i tillegg til å være utøvere av legekunsten. Opptakskravene ble dramatisk hevet og studietiden utvidet til seks år, som et minimum. Legeyrkets status ble også hevet og en meget sterk profesjonsinteresse fulgte med på kjøpet. Alle «alternative» behandlingsmåter ble skilt ut, og kiropraktikk, osteopati og homeopati sortert ut 
som unyttige. Vitenskapeliggjøring og evidensbasering ble kriterier for utvikling av den nye medisinerutdanning. Flexners rapport framholdt Johns Hopkins-universitetet i Baltimore som sitt forbilde. Modellen var bygd på tyske forbilder med to års preklinisk og teoretisk utdanning $\mathrm{i}$ de vitenskapelige enkeltdisipliner før studentene fikk prøve seg i kliniske møter med pasienter. Den biomedisinske modellen fra Johns Hopkins ble etablert som gullstandarden og tapte sin praksisnærhet. I dag kritiseres nord-amerikansk medisinerutdanning for å utdanne «neutered technicians with patients in the service of science rather than science in the service of patients» (Duffy, 2011, s. 275).

Et annet eksempel henter vi fra engelsk lærerutdanning, der de teoretiske delene av studiene ble sterkt kritisert, og i økende grad fjernet på 1990-tallet, og erstattet med praksis i skoler, med praktiserende lærere som veiledere. Statsministeren Margaret Thatcher var som kjent en sterk motstander av humanistiske og samfunnsvitenskapelige fag, og etterspillet etter hennes fall på dette området ble dramatisk. Forfallet av teorifag britisk lærerutdanning ble et utslag av den motsatte tendens enn den man fant i amerikansk medisiner-utdanning i forrige eksempel. Én utdanning oppfattes som teoriløs og en annen for teoretisk. Kuren for den ene er mer praksis og for den andre mindre. Tone Kvernbekk har beskrevet dette som en pendelbevegelse mellom teorityranni og praksistyranni (1995). I våre dager ser vi at prosjektet trekker praksistyranniet inn i norsk hverdag. TeachFirst er et lærerutdanningsprosjekt som bygger på at det er i praksis man utvikler de beste leder- og læreregenskapene. ${ }^{2}$

\section{Teorinær eller praksisnær - skal de to aldri møtes?}

Profesjonsstudier har en lang tradisjon med at studiene oppstår på praksisstedet, sykepleierne er ett eksempel (Elzinga, 1990), elektroingeniørfaget et annet (Terman, 1998). I historien til norsk sykepleierutdanning var det misnøyen med de ufaglærte kvinnene som hjalp leger med behandling, som motiverte utdanningen. Først gikk de gjennom et kortvarig

2 http://www.teachfirstnorway.no/ 
kurs og som så ble gradvis utvidet. Vitenskapliggjøringen utviklet seg gjennom 1900-tallet inntil faget ble innlemmet som høyere utdanning med reformen i 1976. Sykepleierstudiet på tre år forutsetter fortsatt at halvparten av tida brukes på praksissteder, men utfordres i dag av simuleringsøvelser som variasjon av praksis. Elektroingeniørfaget startet med dyktige smeder i workshoper i industrien, og som opp til 1960 ble helt akademisert, delt opp i disiplinfag, og kandidatene ble sosialisert inn i akademias suksesskriterier (Terman, 1998). Praksis skiftet fokus fra det yrket man trente for å komme inn i til sterile laboratorieøvelser. Utøveren av yrket eller håndverket - eller industrien - ble tonet ned, mens de som forsker i faget ble det nye referansepunkt. Akademisering av et fag blir da et hendelsesforløp der fagets forskere blir fagets skapere, og ikke den virksomhet den springer ut fra.

I politikk og retorikk rundt høyere utdanning er det blitt viktig å framheve forskningsbasert utdanning. Det festes stor tillit til at forskerne tar med seg sine forskningsprosjekter og gjør sitt arbeid populært og tilgjengelig i klasserommene. Tanken er at dette vil gi studentene innblikk i forskningens mysterier og danne studentene til å tenke som foreleserne på vitenskapelig vis. Skal man følge vitenskapssosiologen Philip Stokes, ville Thomas Edison trukket med seg sine studenter til workshopen og prøvd ut om materialer egnet seg, om bøyingen på glødetråden var riktig og voltstyrken adekvat. Nils Bohr ville dratt studenten inn framfor en tavle og skrevet mens dialogen forløp, mens Louis Pasteur ville både vært i meieriets laboratorium og foran tavlen med sine studenter (Stokes, 1997). Bohr ville latt tenkningens praksis fått forrang, Edison ville latt utprøvingens praksis ha prioritet. Pasteur ville søkt å forene de to. Stokes skiller mellom de ulike praksisenes verdi for erkjennelse (Bohr) og praktisk nytte (Edison), og i Pasteurs tilnærming til forskning er de to dimensjonene like viktige - og, ifølge Stokes, mest høyverdig.

I nyere vitenskapssosiologi blir gjerne forestillingen om at Bohrs arbeidsmåte og prinsipper for vitenskapelig arbeid er normaltilstanden, klassifisert som eksempel på en Modus 1-tenkning innen feltet. Dette er, mener mange, en idealisert posisjon, mens virkeligheten viser en forskningshverdag som er mye mer preget av samarbeid med eksterne partnere. Det er mange organisasjoner og institusjoner som driver egen 
forskning utenfor universitet og høgskoler. De driver praktisk utøving av yrker og profesjoner som hører til det ypperste på sitt område, og driver fram innovasjon som på lengre sikt flyter inn i forskningsverdenen. Da snakker vi om en Modus 2-forestilling, der det må anerkjennes at kunnskapsproduksjonen også foregår utenfor institusjonens grenser. Både Pasteur og Edison er for så vidt Modus 2-forskere, og med Pasteurs innretning vant han i Stokes' bok posisjonen som den som søker erkjennelse og praktisk nytte i ett og samme ærend. Akademisering følger med andre ord både en erkjennelsesvei og praktisk tillempingsvei - både en unyttig og en nyttig vei. I vår nære fortid ble dette knyttet til et skille mellom grunnforskning og anvendt forskning.

Er det slik vi tenker oss den ideelle pedagogiske virksomheten i høyere utdanning også? Kan vi da si at praksis og teori møtes i fred og ikke som polariserende motstandere?

\section{Kunnskapsfilosofien og kunnskapspolitikken}

Moderne kunnskapsfilosofer finner dyp inspirasjon i antikkens innsikter, især Aristoteles. Gustavsson (2000) skjelner også mellom de kunnskapsformene Aristoteles bygde sine system på: episteme, techne og fronesis. Det er fristende å hevde at Edison var sterkt engasjert i å få ting til en ekte advokat for Techne. Likedan var Bohr opptatt av viten for vitens skyld - altså en rendyrket epistemiker. I dette mønsteret kan da Louis Pasteur sies å passe inn i det som forbinder det nyttige (techne) og det sanne (episteme) med det som gavner brukere - altså det fronetiske - eller kloke. I Stokes' modell fantes også en fjerde kategori: den der forskning har lite å si for vår erkjennelse og for vår nytte. I høyere utdanning må vi innse at vi unntaksvis kan lage forskning som peker seg ut over det relativt beskjedne i begge dimensjoner. Det er stor forskjell på hvordan vi arbeider og hvilke betingelser vi har for å skape kunnskap. Vi trenger dermed å trekke inn hva vi gjør som lærere i høyere utdanning - og som kan skape håp om innflytelse og virkning på feltet.

Innholdet i det akademiske arbeidet er ikke lett å klassifisere, og det er store forskjeller mellom stillingsgrupper. Professorer har som regel langt større råderett over sin arbeidstid enn universitets- og høgskolelektorer. 
Politikeres og myndigheters innflytelse på innholdet i arbeidet varierer også sterkt. Bentley og Kyvik (2012) viser at i USA, som har mange finansieringsformer for høyere utdanning, vil forholdet til myndighetene eller staten - være annerledes enn f.eks. i Norge, eller i Tyskland. I land som har adoptert en humboldtsk modell for høyere utdanning, er troen på at fri forskning bør finne sted uten sterk statlig styring av hva det bør forskes og undervises på, svært sterk. Samtidig lever en med spenningen om at myndighetene ønsker seg mer viten på bestemte forhold, og at forskningspolitikken vris etter politikere og myndigheters ønske, og ikke etter forskernes (Kjelstadli, 2010; Hessen, 2018). Den samme skvisen setter politikerne også på undervisningstilbud man ønsker å støtte.

Distriktshøgskolene ble etablert for snart 50 år siden, med sikte på å utdanne for markedet, og etableringen ble fulgt av heftige diskusjoner om høyere utdanning skulle være en børs eller en katedral. Diskusjonen blusser opp igjen til stadighet og med nye konfliktlinjer. Sist ser vi disse spørsmålene heftig debattert gjennom fusjoneringen av læresteder som følge av Stjernøutvalgets utredning (NOU 2008:3 Sett under ett). Myndighetene mener at større og fusjonerte læresteder vil skape bedre studier og bedre forskning som betjener studenter og samfunn bedre. De antas å være mer effektive og slagkraftige. Dette er hovedinnholdet i dagens kunnskapspolitikk, og linjene derfra til kunnskapsfilosofien skissert ovenfor er blitt veldig tynne og lange. Det er behov for å se litt nøyere på hvordan de tre dimensjonene techne, episteme og fronesis finner sin plass.

\section{Klokskapen i høyere utdanning}

Den enkleste framstillingen av hva som skal være universiteter og høgskolers oppgave i samfunn, er at de skal drive med forskning, undervisning og formidling - og der den tredje dimensjonen er blitt sterkere markert i de to siste tiårene. En litt mer kritisk gransking av de tre områdene leder til spørsmål om undervisningens kvalitet og relevans, om forskningens nytte og samfunnets behov for informasjon og innovasjon. Sektorens aktører har historisk sett vært relativt lite observante på hvordan samfunnsinteressene ivaretas. Utbyggingen av høyere utdanning på 1960-tallet bygde på analyser av hvilken arbeidskraft landet trengte, og det skapte nye 
distriktshøgskoler, og økning av studieplasser ved universitetene, særlig i Trondheim og Tromsø. Først på 1980-tallet vokste det fram i Norge et sett av utadrettede tiltak som forskningsparker, forskningsformidlingstiltak og en voksende oppdragsforskningsvirksomhet. I begynnelsen av 1970-tallet ble det satt i verk universitetspedagogisk opplæring, og forskeropplæring ble systematisert, først i teknisk-naturvitenskapelige fag, og på 1980-tallet også for humanistiske og samfunnsvitenskapelige fag.

Til tross for den voksende bekymring for at kvaliteten på de tre områdene ikke var god nok - og måtte forbedres gjennom opplæring - ble det stadig oftere reist spørsmål om etikk og sosialt ansvar i høyere utdanning (Tranøy, 1986). Spørsmål som rørte ved hvordan verdier og normer ble forvaltet, ble håndtert gjennom vekslende oppmerksomhet om utdanningers potensial for danning. Studentenes motstand mot billige og nytteorienterte studier på 1960- og 1970-tallet og krav om grundige, allsidige og langvarige utdannelser var uttrykk for at studentene ønsket seg danning samtidig med utdanning. Gjennom tilslutningen til Bologna-avtalen (1999), og Kvalitetsreformens tiltak som modulisering og rasjonalisering av utdanningsforløpene (2003) til en kortere og mer skoleliknende struktur, så man en tendens til mer kontroll over studenters atferd og tenkning.

I neste ledd ble Kvalifikasjonsrammeverket (NKR) med standardisert opplisting av forventede læringsutbytter sett på som skritt i retning av en mekanisert oppfatning av utdanningens formål (Gynnild, 2017). Reaksjonen kom i form av at flere universiteter gikk sammen om å opprette et dannelsesutvalg, ledet av Inga Bostad ved Universitetet i Oslo. Innstillingen som kom i 2009, pekte på behovet for at studentene fikk anledning til å integrere og modne sin lærdom gjennom debatt og etisk prøving. Behovet for kritikk av innhold og undervisningsformer ble også ytret gjennom universitets- og høgskolepedagogers skarpe analyse av Kvalifikasjonsrammeverkets omsetting til studieprogram og emneplan-nivået (Skodvin, Handal, Lycke \& Solbrekke, 2012). Tendensen til å tone etiske spørsmål ned, kan spores ved at NKR erstattet «holdninger» som kategori for læringsutbytter med «generell kompetanse».

Dette etiske vakuumet fordrer etter vårt syn at utdanning, forskning og formidling ikke er en tilstrekkelig bred beskrivelse av høyere utdanning, især når en mener å skrive noe om hvordan polene teori og praksis 
kan plasseres i sammenhengen. Den etiske dimensjonen må framheves og tydeliggjøres.

\section{Klokskap og «scholarship» i forskning, undervisning og formidling}

En modell forskergruppen vår bruker for å begripe allsidigheten i det akademiske arbeidet og spennet mellom praksis og teori, er utviklet i USA av Ernest Boyer og en forskergruppe etablert ved the Carnegie Institute for the Advancement of Teaching and Learning (1990). Siden 1990 er modellen deres videreutviklet og brukt på mange områder. Modellen tar fatt på forestillingen - og ideologiene - om at det å drive forskning er den mest prestisjetunge virksomheten ved universiteter og høgskole. De foreslo en mer balansert framstilling mellom de aktivitetsområder akademikere i høyere utdanning faktisk har. De analyserte hva akademikere ved amerikanske høyere læresteder faktisk gjorde og tenkte om sin gjerning i sin arbeidstid. Ut fra dette foreslo Boyer fire områder de kalte «scholarships» i betydningen «å være lærd». Forskning (scholarship of discovery) var ett av dem, og undervisning (scholarship of teaching and learning) et annet. Det tredje, som ble kalt «scholarship of integration» kan best oversettes til «danningsarbeid» og reflekterer akademias forsøk på å skape relevans og mening for studentene gjennom studiene. Til sist framstilte de et område kalt «scholarship of application», som handlet om samarbeid og samvirke med det sivile samfunnet. Disse fire måtene å være lærd på er ikke gjensidig ekskluderende. Snarere gir de et rikere inntak til å forstå hvor sammenvevd vår virksomhet $\mathrm{i}$ akademia er.

For å sammenligne med vår norske treleddede forståelse av høyere utdanning ser vi at forskning og undervisning tilsvarer lærdomsområdene «teaching and learning» og «discovery». Lærdomsområdet «application» er gjennom de siste år videreutviklet av engasjerte fortolkere av tenkningen til å handle om «engagement and collaborative action» (Pleasants, 2017). Vi kan enkelt si at all aktivitet som dreier seg om samarbeid med eksterne virksomheter der ansatte i høyere utdanning enten samarbeider med, lærer av, forsker med eller formidler til dem, er vi i en relasjon der vi er engasjerte i samhandling. Datainnsamling, 


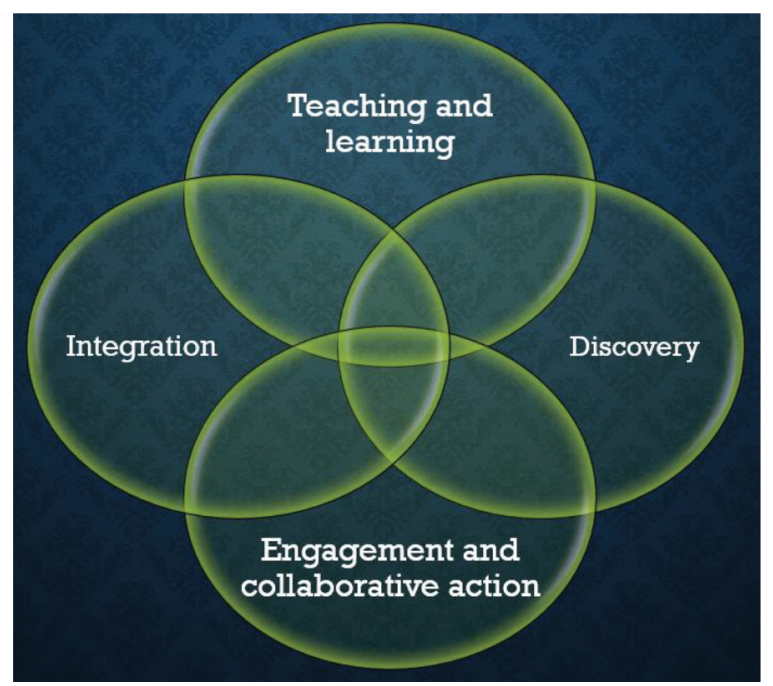

Figur 1. Boyers fire «Scholarships».

praksisopplæring, dialoger, aksjonsforskning, oppdragsforskning, brukerstyrte eller brukerinitierte prosjekter er eksempler på sterke relasjoner, mens forskningsformidling, publisering av bøker og artikler, deltakelse i radio eller tv, intervjuer og innlegg i aviser er en annen type mer uforpliktende relasjoner. I Boyers modell blir det å være en lærd akademiker innenfor «integration» en som forestår dannelsesoppdraget. Å være en akademiker som tar studentenes opplevelse av helhet og mening i en sosial og etisk ansvarlig sammenheng, er en viktig ekstra funksjon - som tillegg til de tre andre. Å være lærd innenfor alle fire områdene blir - det antakelig uoppnåelige - målet for alle som arbeider med undervisning i høyere utdanning.

\section{Å være en lærd lærer i høyere utdanning}

Det å være lærde lærere, som i vår terminologi er å håndtere undervisning og læring på tilsvarende profesjonelle måte som man er forsker på, får knapt oppmerksomhet fra styresmaktene. Før Stortingsmeldingen med tittelen «Kultur for kvalitet i høyere utdanning» ble lagt fram (Kunnskapsdepartementet, 2017), har styresmaktene vist laber interesse for hva dette er. Man har riktignok etablert sentre for «fremragende 
undervisning», men med marginalt med ressurser i forhold til hva tilsvarende sentra for fremragende forskning får.

I begrepet «forskningsbasert undervisning» finner vi mye av kompleksiteten i de to rollene «forsker» og «lærer» i høyere utdanning. Fra de første universitetene ble dannet har det å være en kompetent lærer i høyere utdanning blitt forstått som å være en god foreleser. Det er først fra midten av 1600-tallet at en «forskerrolle» blir tydelig ved siden av «foreleseren». Tidligere var professorene rendyrkede forelesere som unntaksvis skrev egne verk. De foreleste «over» klassiske tekster - som altså var foreleserens forskningsobjekt.

I dag skiller f.eks. UHR mellom fire typer forskningsbasert undervisning: a) læreren underviser forskningsbasert innhold, b) eller om forskningsprosess og vitenskapelig tenkemåte, c) undervisning der studenten aktivt deltar i diskusjon av et forskningsbasert innhold og d) undervisning der studenten inngår i «undersøkende» læreprosesser (2010). Geografene Healey og Jenkins (2008) skiller mellom studentene som tilskuere og deltakere, og om innholdet i undervisningen handler «om forskning» eller er en involvering «i forskning». Den problematiseringen krever en radikal nytenkning over forholdet mellom «fagets gjenstand» og formidlingen av det. Å utvikle et «scholarship of teaching and learning» handler da om helheten av «å vite om saksforholdet» og «å undervise om saksforholdet». I tillegg handler det om å undervise bedre og bygge denne utviklingen på viten og erkjennelse over tid. Det å være en lærd lærer handler da minst om to etapper - å nå et akseptabelt nivå å utvikle undervisningen fra, for så å utvikle undervisningen til høyere nivåer derfra gjennom karrieren. I dag er «The Scholarship of Teaching and Learning» et tema for konferanser, tidsskrift og internasjonale vitenskapelige organisasjoner (Allern, 2011) - og med et gryende norsk begrepsapparat, som foreslått av Sandvoll, Winka og Allern (2018): akademisk loererskap. Nasjonalt er det utviklet universitets- og høgskolepedagogiske minimumskrav til ansattes pedagogiske kompetanse. Stortingsmelding nr. 16 (2016-2017): Kultur for kvalitet i høyere utdanning (Kunnskapsdepartementet, 2017) foreslår at det blir obligatorisk å ha en slik utdanning, og at professorkompetanse også forutsetter dokumentert pedagogisk utviklingsarbeid. Med andre ord blir det et krav om at 
vitenskapelig publisering innenfor forskning også blir komplettert med vitenskapelig publisering innenfor undervisning i det området man har sin disiplin- eller profesjonsekspertise.

Arild Raaheim definerer forskningsbasert undervisning slik: «Forskningsbasert undervisning er undervisning som tar hensyn til og bygger på det forskning har vist fører til god læring.» (Raaheim, 2010, s. 56). Raaheim forutsetter her at det dreier seg om læring av faget eller saksforholdet undervisning handler om og at målet blir å lære faget raskt og effektivt. Dette gjør at et «Scholarship of teaching and learning» kan bli instrumentell og innadvendt og for lite samfunnsrettet eller danningsorientert. Vi ser raskt at med å tenke inn relevansen for samfunnet og dannelsesaspektet blir oppdraget bredere og i beste forstand mer akademisk. «God læring» bør ikke bli et gitt forhold beskrevet av kvalifikasjonsrammeverket og innenfor snevre betraktninger om hvordan lære et stoff på mest effektiv måte.

En praksisnær undervisning vil være en komplementær eller kritisk versjon av den forskningsbaserte, fordi praksisnærhet tenker inn danningsoppdraget og trekker inn studentene som representanter for samfunnet og den framtida studentene utdannes til. Disse dimensjonene er i beste fall implisitte og uutsagte i konvensjonelle tolkninger av forskningsbasert undervisning. Vi trenger å se sammenhengen mellom dannelsesoppdraget og det engasjerte og samfunnsorienterte ansvar koblet sterkere til de øvrige to. I denne boken tar vi opp hvordan studieformer som nærmer seg praksis, på fornuftige måter kan oppfylle danningsoppdraget bedre, samtidig som samfunnsengasjementet syes inn i det daglige og faglige virke i høyere utdanning.

Først og fremst må studentene anerkjennes som utøvere av sin egen praksis - der deres forkunnskaper, personlighetstrekk, fortid og samtidighet, kjønn, etnisitet, klasse og opplevelse av hverdagen og framtida må få en mer sentral plass. I moderne danningsteori er studentenes eksistensielle forutsetninger for å kunne åpne seg for fagene i en disiplin eller profesjonsutdanning grunnleggende for å se sammenhenger i fagstoff og mellom sine faglige og personlig ambisjoner. Pedagogen Lidveig Bøe sier at for studenten handler det om å balansere utdanningsambisjoner med sitt livsprosjekt og bygge sin identitet som menneske (2009). Arbeid, 
fritid, kjærlighet og seksualitet, rus og underholdning er elementer som konkurrerer med nøysomhet og pliktetikk. Statens idealbilde av «studieatleten» slik det ble beskrevet i Kvalitetsreformen, er mindre representativ enn man tror. Mange ansatte i høyere utdanning stiller i liten grad spørsmål som: «hvorfor møter ikke studentene til undervisning?» eller «hvorfor fullfører de ikke sine studier?» Tall for gjennomstrømming i norsk høyere utdanning indikerer at lærestedene generelt sett bommer på hva studentene evner å fullføre. Det største problemet for mange studenter er å se relevansen av studiene for sin framtid, og hvordan emnene og forberedelsene de deltar i på studieprogrammene, støtter hverandre i den faglige progresjonen.

En amerikansk universitetsrektor hadde en lang erfaring fra sykehusledelse, der han stadig ble spurt av kritiske krefter: «Hvor mange pasienter har dere skadet i dag?» Han foreslo et tankeeksperiment for universitetsrektorer der de spør det samme spørsmålet for sin institusjon: «Hvor mange studenter har vi skadet i dag?», og fortsatte: «tjener vi våre studenter og samfunnet på den beste måten?» (Welch, 2011). Dersom man som en lærd lærer i høyere utdanning ikke trekker inn studentenes opplevelser og erfaringer, kan man like gjerne si som den amerikanske professoren Marc Cohan: «Jeg var et dårlig eple i kurven» (2009). Cohans vei til lærdom gikk gjennom å lære studenter å kjenne og finne veiene til deres opplevde og praktiserte liv. Den engelske professor emeritus Ronald Barnett sier det enda sterkere:

Studentens «væren i verden» må være det sentrale. Å føle usikkerhet og reagere på usikkerhet, vinne selvsikkerhet gjennom å kaste seg ut i de motsigelsene en møter og engasjere seg med den motstanden en får, samtidig med at en utvikler tålmodighet og mot: Det er det som er viktig. For å komme dit må pedagogikken endres fundamentalt. (Barnett 2000, s.170-171 (forfatterens oversettelse))

\section{Kvalitetsdiskurser i norsk høyere utdanning}

Sosialantropologen Tian Sørhaug benyttet i et foredrag anledningen til å vri litt på tittelen til Stortingsmelding 16 (2016-2017) «Kultur for kvalitet i høyere utdanning». Han spurte «hva er kultur?» og «hva er kvalitet?». Svarene er at kultur er «det vi trenger å forstå for å forstå», og kvalitet er «det 
vi alle vil ha». Slik sett blir denne faktoroppløsningen til at det stortingsmeldingen handler om er å finne ut «hva vi trenger å forstå for å forstå det alle vil ha i høyere utdanning». Om vi griper tilbake til Stortingsmelding nr. 27 fra 2000-2001, sies det der at «Den beste læring oppnås der studenten er intenst tilstede med hele sin skaperkraft» (s. 4.) (Kirke-, utdanningog forskningsdepartementet, 2001). I den litteraturstudien NIFU laget på oppdrag fra Kunnskapsdepartementet for å undersøke kvaliteten i norsk høyere utdanning, fant en at kvalitet ikke kan beskrives særlig presist, og at man kontinuerlig trenger å presisere hva man mener er av høy kvalitet, og hvordan man bedømmer den (Damsa mfl., 2015). Lee Shulman (2002) definerte undervisning av høy kvalitet på dette viset: Når undervisningen motiverer og engasjerer studentene, og studentene gjør framgang $\mathrm{i}$ studiene, når de får øvet seg på ferdighetene som trengs, og får delta $\mathrm{i}$ ettertanke og kritisk refleksjon, slik at de får øving i å vurdere sin egen læring mot fagområdets standarder - da holder den høy kvalitet. Dersom praksisnærhet skal være en del av denne beskrivelsen, kan det være viktig å se hvordan kvalitet kan lokkes fram i ulike sammenhenger. Vi vet at studier som oppfattes som behagelige og enkle, godt kan få god score i en trivselsundersøkelse, mens et studium med harde krav og stort frafall oppnår det motsatte. Kombinasjonen av å skape studier der studentene trives og utvikles, samtidig med at de utfordres og motiveres til å rette sin innsats mot flere oppdagelser og mer kompetanse, synes å ligge i det gylne snittet for vår innsats. I de kommende kapitlene vil vi presentere ulike tanker om på hvordan praksisbegrepet i utdanninga kan forstås som bidrag til «å forstå det vi trenger å forstå» - altså kulturen - for det vi alle vil ha - altså kvalitet.

\section{Presentasjon av bokas bidrag til den praksisnære undervisningens praksis - og teori}

Grete S. Halvorsen: Hva kan praksisnær undervisning være?

Halvorsens bidrag til denne boka er en analyse av hvordan praksisnoer undervisning er forstått i dagens faglitteratur. Ikke overraskende finner 
hun at det er mange - og lite enhetlige - beskrivelser av hva det er. Hennes bidrag handler om hva det kan være. Faglitteraturen beskriver dette hovedsaklig som forsøk på å samle teori og praksis og skape en mer helhetlig forståelse. Integrasjon er et hyppig brukt ord, og ofte er det yrkespraksis som er ment som praksis. Heller ikke ovennevnte stortingsmelding gir annet enn relativt overfladiske blikk på at aktive studenter lærer mest og best når de opplever nærhet til menneskers virkelighet, og når dets handlinger er naturlig integrert $\mathrm{i}$ undervisningen. Halvorsen foreslår at vi kaster rundt på våre tilvendte forestillinger og griper fatt $\mathrm{i}$ erfaringen, og ser den i lys av implisitt og eksplisitt kunnskap, taus eller artikulert viten, innvendighet og utvendighet og deltaker-tilskuer-perspektivet - kjente begrepspar i kunnskapsfilosofien. Hun ser på hva studenten «gjør og gjennomgår» i sin læringsprosess som verktøy for å kjenne viten på innsiden og søke utenom den for å plassere den i helheten. Vekslingen mellom innenfra og utenfra er viktig for å kjenne praksisen som fenomen - fra tenkningen om den, til tenkning og handling med den.

Gisle Heimly, Egil Eide og Njål Vidar Traavik: Psykologisk kontrakt med studenter i høyere utdanning

Studenter møter til sin utdanning med ulike forventninger og er oftest nokså spørrende til hva det er som venter dem. I noen grad skyldes det at de ikke helt har reflektert over hva de forventer av studiet, og studiene kommuniserer ikke alltid hva studentene skal gjøre, hva de skal lære, hvordan de skal samarbeide. Dette forsøket ble satt i gang for å utvikle partnerskap mellom studiet og dets studenter, gjennom en psykologisk kontrakt. Etter festligheter og oppstart fant forfatterne gjennom å bruke ulike forhandlingsmetoder at studentene nokså kontant ønsker å ha en relasjon til dem som underviser, og at lærerne presenterer oversikter og struktur som gir studentene en forutsigbarhet. De forventer at studiene demonstrerer relevans for deres framtidige yrke. I prosessene fram til den psykologiske kontrakten fant forfatterne ut at studenter og lærere kan bli enige om gjensidige forventninger og dermed blir mer personlig delaktige og samarbeidende i arbeidet med å lage et læringsmiljø. 
Anne-Lise With: Veiledningssamtale for første års studenter: Et innspill til praksisnærhet og studiekvalitet.

Med Kvalitetsreformen var det en intensjon at institusjonene skulle tilby mer tilbakemelding og faglig veiledning. I tillegg ble det en større innsats på å veilede studentene til å se fram mot framtidig yrkesvalg. Hensikten var å gjøre studentene mer orientert mot arbeidsmarkedet og reflektere over hvordan de kunne se seg selv som mer rasjonelle aktører i valg og utforming av framtidig yrkeskarriere. Prosjektet ForVei ved NTNU skapte en god plattform for å etablere veiledningsordninger med breiere formål. «ForVei - veiledningen» innebærer verdimessig at studenten er verdt oppmerksomhet, er verdt å bli lyttet til, at studentens opplevelser, tanker og erfaringer tas på alvor og gis tid. Som relativt fersk student blir du spurt, lyttet til; veilederen interesserer seg for deg - og respekterer deg. Kapitlet viser hvordan studentene tok imot tilbudet, og hva det betydde for deres personlige utvikling og karrieremessige rettethet.

Anne Røisehagen: Seminaret som undervisningsform i høyere utdanning

Seminaret er en undervisningsform med lang forhistorie i europeisk høyere utdanning, og er et interessant fenomen i betydningen av "praksisnær» undervisning. Begrepet seminar brukes ganske upresist og vekker ulike assosiasjoner. Noen mener det er smågruppe-undervisning der læreren beholder sin posisjon fra forelesningen. I dette kapitlet tilbys det en mer presis definisjon og utforming av seminaret. Seminaret skal ideelt sett utdype, øve, prøve ut og eksperimentere, slik at studenter ikke bare bruker forkunnskaper, men også sine kroppslige og emosjonelle egenskaper til å involvere seg med lærestoffet. Studentens praksis i masseutdanningens tid blir ofte avgrenset til forelesningsrommet, kantinepraten og gruppearbeid. I seminaret får en sjanse til å sy erfaringer, oppfatninger og de teoretiske innsikter sammen som et arbeid mot å skape sammenhenger for studenten. Eksemplene er hentet fra et systematisk arbeid med seminarer i et disiplinfag, og dokumenterer at studenter som bearbeider stoffet gjennom deltakelse i seminarer, oppnår å lære faget grundigere enn de som avstår. 
Yngve Nordkvelle, Odd Rune Stalheim, Line Wittek, Thomas de Lange, Trine Fossland og Monika Nerland: Praksisnær undervisning som simulering og rollespill i høyere utdanning

I undervisningen av advokater tok man på 1300-tallet til å arrangere «liksom»-rettssaker i England, og denne tradisjonen holdes i hevd fortsatt. Rollespill har blitt brukt i høyere utdanning i både disiplinog profesjonsfag, og i helse- og sosialfag har simuleringer med dukker blitt et sentralt element i mange utdanninger. I dette kapitlet ser forfatterne på hva som er viktige likheter mellom disse formene for undervisning, og hvilken betydning det kan ha å lage situasjoner der den samfunnsmessige, profesjonelle praksis utfoldes innenfor institusjonens vegger.

Eli Skjeseth: Å skrive om hendelser i egen praksis?

Veiledning er et voksende felt i organisasjons- og utdanningslivet. I etterutdanning av folk som er i veilederstillinger og som skal utvikle sin veiledningspraksis, forteller Skjeseth om privilegert posisjon fordi veiledernes yrkespraksis er representert i deltakerne. Praktikerne er allerede der, og som lærer henter hun inspirasjon til sin praksis. I kurset bidrar studentene med å skrive tekster om sitt virke som veiledere, fra rene praksisfortellinger til økende kompleksitet der de selvgranskende tekstene i økende grad framstiller hvordan den kunnskap de har, er vevd sammen med andre forhold. Erfaringer fra barndom og tidligere arbeid og utdanning, forhold til kolleger og arbeidsplass og emosjoner som vekkes i møtet med klienter og institusjoner, med andre ord der hvor kunnskap og erfaring utfolder seg - eller situeres - som læringsteorien kaller det, lokkes fram. Skjeseth beskriver den metodiske måten hun arbeider på for å få fram den økende kompleksiteten, som studentenes egen teoretisering. Hun utvikler begreper om praktiske utøvere som tenker «opp» og tenker «ned» i registrene av erfaringer og handlinger, og hvordan deltakerne merker seg endringer i egen tenkning - og handling - som veileder i takt med sitt studium. 
Inger Marie Bakke, Håkon Glommen Eriksen og Lene Nyhus: Å lære om seg selv gjennom å observere andre

Når læringsmålene i studiet handler om å øke selverkjennelse og forutsetninger for å veilede andre, blir «selvet» både studieobjekt og studiesubjekt. Ganske visst er det skrevet innsiktsfulle bøker om dette, men det krever en nennsom og grundig pedagogisk bearbeiding for avklare de betingelsene for kommunikasjon som ligger omkring den profesjonelle kommunikasjonen i veiledning. Studentene er gjerne erfarne yrkesutøvere, men er også unge og ferske i sin profesjonelle utvikling, og alle står i situasjoner der de kan bruke sin hverdagslige praksis som utgangspunkt for emnet. Studentenes bearbeiding av de forholdene i egen bakgrunn, væremåte og forforståelse som påvirker kommunikasjon på gode, onde, bevisste og ubevisste måter, krever at refleksjonsevnen utvikles systematisk. «Noe» må settes i bevegelse, og kapitlet gjør rede for hvordan studentene arbeider med observasjon, notattaking, veiledning, refleksjonsarbeid og loggføring for å utvikle det settet av «data» studentene trenger for å finne seg selv i farvannet. Det å eksponere praksis er en forutsetning for å skape situasjoner der virkeligheten er så nær at identiteten kommer i spill, men på en ansvarlig måte der studiet skaper trygge rammer for refleksjon, åpenhet og ettertanke.

Njål Vidar Traavik, Egil Eide og Gisle Heimly: Feltarbeid - forskande tilnærming til praksis

Et viktig moment i filosofien rundt feltarbeid og observasjon er å gjøre det kjente fremmed og det ukjente kjent. En må ut av skoene en tråkker i til daglig, og bøye blikket til å lære noe nytt i det en mener seg å kjenne. Denne artikkelen forteller om et forsøk på å la studenter i praktisk- pedagogisk utdanning for yrkesfag studere den virkeligheten skoleslaget deres elever kommer fra, nemlig ungdomsskolen, representerer. Studentene har erfaring som elever fra lang tid tilbake, og er vel kjent med den norske undervisningskulturen. I forsøket søkte forfatterne å legge til rette for at studentene utforsket en delkultur som var velkjent i det ytre, men likevel ganske ukjent. Denne måten å 
praksisrette undervisninga ble oppfatta som meningsfull og lærerik, og forfatterne legger fram forslag på at dette kan brukes på bredere front i lærerutdanninga.

Randi Røthe: En dags praksis. Hvordan bidra til at studentene finner sammenhengen mellom teori og den virkelige verden?

Det første året på bachelorstudiet i pedagogikk på Høgskolen i Innlandet teller opp mot 200 studenter. I andre semester skal alle være på en skole og stå for undervisning og drift dagen til ende Røthes kapittel handler om hvilke endringer denne enkelthendelsen skapte i studentenes opplevelser av studiet. En hurtig og spesifikk praksis er nok til å rykke studenter ut av sin egen studentlivspraksis og gi dem en smak av hvordan yrkespraksis fortoner seg. Røthe framhever Jon Frode Blichfeldts definisjon av praksis som måten man dyktiggjør seg på. Studentene skriver at dagen i praksis ga dem en sterk impuls om hva slags arena pedagoger skal utdanne seg til. Brått fikk dem mange knagger å henge mye av sin egen skoleteori på.

Ingrid Tvete: Praksisnær undervisning - en forutsetning for innovasjon og entreprenørskap

Nyskaping og ansvar for samfunnsmessig framgang er behandlet på framskutt plass i en rekke offentlige dokumenter. Entreprenørskapstanken er trukket inn i mange sammenhenger, og forventningene til at høyere utdanning skal skape individer som overskrider konvensjonene og skaper verdier for framtida, er stor. Tvete trekker disse forestillingene inn mot begrepet praksisnærhet og hvordan studenter ikke bare skal «få seg en jobb», men også omskape sine personlige egenskaper og ferdigheter til å møte et omskiftelig framtidig arbeidsliv.

\section{Litteratur}

Allern, M. (2011). Scholarship of Teaching and Learning (SoTL) i Norge:

Pedagogiske mapper som bidrag til pedagogisk diskurs. Uniped, 34(03), 20-29. 
Barnett, R. (2000). Realizing the university in an age of supercomplexity. Buckingham: Society for Research into Higher Education \& Open University Press.

Bentley, P. J. \& Kyvik, S. (2012). Academic work from a comparative perspective: A survey of faculty working time across 13 countries. Higher Education: The International Journal of Higher Education and Educational Planning, 63(4), 529-547. https://doi.org/10.1007/s10734-011-9457-4

Boyer, E. L. (1990). Scholarship reconsidered: Priorities of the professoriate: A special report. Princeton, NJ: Carnegie Foundation.

Bøe, L. (2009). Studentar: I statens fald eller i eit livsmangfald? Uniped, 32(3), 55-67. Cohan, M. (2009). Bad apple: The social production and subsequent reeducation of a bad teacher. Change, 41(6), 32-36. https://doi-org.ezproxy.inn.no/10.1080/ooo 91380903270151

Damsa, C., de Lange, T., Elken. M, Esterhazy, R., Fossland, T., Frølich, N., Hovdhaugen, E., Maassen, P., Nerland, M. B., Nordkvelle, Y. T., Stensaker, B., Tømte, C., Vabø, A., Wiers-Jenssen, J. \& Aamodt, P. O. (2015). Quality in Norwegian higher education: A review of research on aspects affecting student learning. NIFU report 2015:24. Oslo: Nordic Institute for Studies in Innovation, Research and Education.

Duffy, T. P. (2011). The Flexner report - 100 years later. Yale Journal of Biology and Medicine, 84(3), 269-276.

Elzinga, A. (1990). The knowledge aspect of professionalization: The case of science-based nursing education in Sweden. I R. T. M. Burrage (Red.), The formation of professions. London: SAGE.

Gustavsson, B. (2000). Kunskapsfilosofi: tre kunskapsformer i historisk belysning. Stockholm: Wahlström \& Widstrand.

Gynnild, V. (2017). Læringsmål eller læringsutbyttebeskrivelse? En empirisk, konstruktiv studie av begrepsbruken. Norsk pedagogisk tidsskrift, 101(3), 225-238.

Healey, M. \& Jenkins, A. (2009). Developing undergraduate research and inquiry. Higher Education Academy. Hentet fra: http://www.heacademy.ac.uk/assets/ documents/resources/publications/DevelopingUndergraduate_Final.pdf

Hessen, D. O. (2018). Sannhet til salgs: et forsvar for den frie forskningen. Oslo: Res publica.

Hiatt, M. D. \& Stockton, C. G. (2003). The Impact of the Flexner Report on the fate of medical schools in North America after 1909. Journal of American Physicians and Surgeons, 8(2), 37-40.

Kirke-, utdannings- og forskningsdepartementet. (2001). Gjør din plikt - krev din rett: Kvalitetsreform av høyere utdanning: Tilråding fra Kirke-, utdannings- og forskningsdepartementet av 9. mars 2001, godkjent i statsråd samme dag (Vol. Nr 27 (2000-2001), St.meld. ... (trykt utg.)). Oslo: Departementet.

Kjeldstadli, K. (2010). Akademisk kapitalisme. Siggerud: Res Publica. 
Kunnskapsdepartementet (2017). Kultur for kvalitet, Meld. St. 16 (2016-2017).

Kvernbekk, T. (1995). Om erfaringstyranni eller teorityranni: et vitenskapsteoretisk perspektiv på forholdet teori - praksis. Nordisk Pedagogik, 15(2), 88-96.

Messel, J. \& Smeby, J.-C. (2017). Profesjonsutvikling i utdanning og arbeidsliv: Mastergrad i avansert klinisksykepleie - «mastersyke» eller mestringskompetanse? I S. Mausethagen \& J.-C. Smeby (Red.), Kvalifisering til profesjonell yrkesutøvelse. Oslo: Universitetsforlaget.

Mjøs, O., \& Norge Kirke-, utdannings- og forskningsdepartementet. (2000). Frihet med ansvar: Om høgre utdanning og forskning i Norge: Utredning fra et utvalg oppnevnt ved kongelig resolusjon 30. april 1998: Avgitt til Kirke-, utdannings- og forskningsdepartementet 8. mai 2000 (Vol. NOU 2000:14, Norges offentlige utredninger (tidsskrift: trykt utg.)). Oslo: Statens forvaltningstjeneste, Informasjonsforvaltning.

Nilsen, Y. (2005). En sterk stilling? Norsk Forskerforbunds historie 1955-2005. Bergen: Vigmostad og Bjørke.

NOU 2008: 3. (2008). Sett under ett - Ny struktur i høyere utdanning. Hentet fra https://www.regjeringen.no/no/dokumenter/NOU-2008-3/id497182/

Osland, O. (2017). Om «akademisering» av dei korte profesjonsutdanningane. Nytt Norsk Tidsskrift, 34(04), 428-436. https://doi.org/10.18261/issn.1504-3053-201704-09

Pleasants, H. (2017). Introduction to the scholarship of engaged collaboration. I G. Jamissen, P. Hardy, Y. Nordkvelle \& H. Pleasants (Red.), Digital storytelling in higher education: International Perspectives (s. 317-320). Cham: Palgrave MacMillan.

Raaheim, A. (2010). Loring og undervisning. Bergen: Fagbokforlaget.

Sandvoll, R., Winka, K. \& Allern, M. (2018). Merittering som vitenskapelig tilnærming til undervisning. Uniped, 4o(3), 246-258. https://doi.org/10.18261/ issn.1893-8981-2018-03-06

Shulman, L. (2002). Making differences. A table of learning. Change, 34(6), 36-44.

Skodvin, A., Handal, G., Lycke, K. H., \& Solbrekke, T. D. (2012). Føyelige eller ubøyelige? Universitetspedagogers rolle i implementering av nasjonalt kvalifikasjonsrammeverk. Uniped, 35(2), 18-31.

Solstad, A. G. (2010). Praksisnær teori og teorinær praksis - den nødvendige relasjonen. Norsk pedagogisk tidsskrift, 94(3), 203-218.

St.meld. nr. 27. (2000-2001). Gjør din plikt - Krev din rett.

Stokes, D. E. (1997). Pasteur's quadrant: Basic science and technological innovation. Washington, DC: Brookings Institution Press.

Terman, F. (1998). A brief history of electrical engineering education. Proceedings of the IEEE, 86(8), 1792-1800. 
Thue, F. W. (2017). Høgskoler på randen av universitetsstatus - akademisk løft eller dyp-politisering? Nytt Norsk Tidsskrift, 34(3), 286-30o. https://doi.org/10.18261/ issn.1504-3053-2017-03-06

Tranøy, K. E. (1986). Vitenskapen - samfunnsmakt og livsform. Oslo:

Universitetsforlaget.

UHR. (2010). Utdanning + FoU = Sant. Rapport fra arbeidsgruppe nedsatt av UHR.

Welch, E. (2011). Perspectives: Pursuing quality in higher education. Change, 43(1), 28-30. https://doi-org.ezproxy.inn.no/10.1080/ooo91383.2011.538644 



\title{
KAPITTEL 2
}

\section{Hva kan praksisnær undervisning være?}

\section{Grete Salicath Halvorsen}

Høgskolen i Innlandet

\begin{abstract}
The concept of practice-oriented learning is not used very consistently in contemporary literature. There are numerous and non-uniform descriptions of what it is. This contribution revolves around what it can be. The literature describes this mainly as an attempt to marry theory and practice and create a more comprehensive understanding. Integration is a frequently used word and often it is the vocational practice that is meant by practice. Nor does Norwegian parliamentary report no. 16 from 2016/17 give anything but a relatively superficial glance of the fact that active students learn the most and best when they experience proximity to people's reality and when its scenarios are naturally integrated into the teaching. I suggest that we question our applied concepts and grasp the experience, and see it in the light of implicit and explicit knowledge, tacit or articulated knowledge, internalism and externalism, and participant and spectator - well-known concepts in epistemology. I look at what the student «does and undergoes» in her/his learning process as a tool for realizing the knowledge on the inside and searching outside it with the goal of placing it within the whole. The exchange between inside and outside is important for understanding the practice as a phenomenon - from thinking about it, to thinking and acting with it.
\end{abstract}

Keywords: epistemology, practice-orientation, philosophy of education, forms of understanding

\section{Introduksjon}

Jeg har en stund vært opptatt av frasen «praksisnær undervisning», og jeg har lurt på hva som menes. Hva mener vi når vi snakker om praksisnær i tilknytning til undervisning? Hva mener vi med praksis? Er praksis en handling, en aktivitet, en virksomhet, eller dreier det seg mer generelt og

Sitering av denne artikkelen: Halvorsen, G. S. (2020). Hva kan praksisnær undervisning være? I Y. T. Nordkvelle, L. Nyhus, A. Røisehagen og R. H. Røthe (Red.), Praksisnor undervisning - i praksis og teori (Kap. 2, s. 33-52). Oslo: Cappelen Damm Akademisk. https://doi.org/10.23865/noasp.94.ch2.

Lisens: CC BY 4.0 . 
overgripende om det «å være i verden»? Og hva med ordet «nær»? Dels får det mening gjennom det første leddet, men likevel gjenstår det mange spørsmål: Hva tenker vi - mer konkret - når vi snakker om å være nær praksis? Hvor tett på skal vi være, og hvorfor er dette viktig? Og hvordan kommer vi nær praksis?

Når vi snakker om praksisnær undervisning, er det gjerne undervisningen som produkt, eller gjerne resultat, vi har i tankene. Vi vil at undervisningen skal ha noen spesielle kjennetegn eller kvaliteter: Det vi kaller for praksis, skal være fremtredende.

Men undervisning er i seg selv også en praksis, eller flere praksiser. Det er noe vi gjør. Det er virksomheter og handlinger. Det vi gjør, kan forstås på tre nivåer (Sæverot, 2015, s. 125): Vi planlegger, underviser og vurderer undervisningen. Til disse praksisene er det - mer eller mindre, og på ulike måter - koblet noen tanker, ideer og kanskje teorier. Vi har tanker om hva vi skal gjøre, hvordan og hvorfor. Vi tenker altså både i deskriptive og normative baner. Det kan imidlertid synes som om disse tankene er relativt uavklarte hos mange av oss.

Jeg ønsker i dette kapitlet å diskutere spørsmålene jeg her har reist, for på den måten å bidra til å gi mening til uttrykket "praksisnær undervisning». Jeg arbeider med dette for selv å komme fram til en klarere oppfatning. Jeg har stilt flere spørsmål. Men et spørsmål er også et svar (Gadamer, 2007). Svarene, eller like gjerne fornemmelsene, de foreløpige tankene eller meningene kunne vært formulert som spørsmål, men det virker klargjørende - for meg og forhåpentligvis for leseren - å uttrykke de i en mer bestemt form, slik:

1. Praksis beskriver menneskets eksistensielle virkelighet og dets handlinger i denne virkeligheten. Praksis har med andre ord en værens- og en handlingsdimensjon.

2. Enhver forståelse eller læring bygger på ulike måter på disse to dimensjonene. Derfor bør all undervisning ha praksisnære elementer, hvilket betyr at det eksistensielle - eller livet og virkeligheten - inngår.

Hensikten med dette kapitlet er å begrunne, gi mening til og styrke de to påstandene. 


\section{Hvordan forstår vi uttrykket «praksisnær undervisning»?}

La meg først forsøke å tegne et bilde av uttrykket «praksisnær undervisning» slik det framstår i bruk i Norge i dag. Jeg har gjort søk med frasen «praksisnær undervisning», og en rekke andre nærliggende fraser på Regjeringen.no, Idunn.no og Google.no. Hensikten var å forstå hva myndigheter, fagpersoner og «folk flest» legger i uttrykket «praksisnær undervisning». Jeg gjorde en enkel registrering av antall treff etter søkeordene på de nevnte nettstedene - ikke for å påberope meg en kvantitativ representativ størrelse, men for få en forståelse av den alminnelige, offentlige og faglige meningen med frasen «praksisnær undervisning». Deretter forsøkte jeg å få et overordnet inntrykk av treffene, avgrenset digitalt etter relevans. Jeg gikk inn i hvert enkelt dokument i dette utvalget med de samme søkeordene som jeg brukte i nettstedene, og leste raskt og overfladisk der jeg fikk treff, før jeg lastet ned et tjuetalls artikler, som jeg leste grundig.

Søket viser at praksisbegrepet og frasen praksisnær undervisning er uavklart, og det er i denne sammenhengen gjort få forsøk på å definere begrepene praksis og praksisnær. Videre fant jeg at praksis stort sett tenkes som en motsetning til teori. Praksis forstås også av de fleste som yrkespraksis, og i undervisningssammenheng begrenses dette ytterligere til å gjelde profesjonsutdanningenes yrkespraksiser. Praksisnær undervisning synes altså i hovedsak å forstås som undervisning, der kontakten med utdanningens spesifikke yrkesfelt etableres eller styrkes ved at feltet på ulike måter tas inn i undervisningen, studentene tas ut i feltet eller de tenker seg inn i, og øver i, en konstruert virkelighet.

I noen få artikler (Gjøsæter \& Kyvik, 2015; Halmrast, Taarud \& Østerås, 2013; Heimly \& Bertheussen, 2016; Jordet \& Roland, 2012; Schjølberg, 2013) gir teksten et mer eller mindre klart bilde av hva forfatterne mener med begrepet praksis og uttrykket praksisnær eller praksisbasert undervisning. Ett tema som de imidlertid har felles, og som de er tydelige på, er kravet eller ønsket om å se kunnskap som en helhet: Teori og praksis må i større grad integreres.

Halmrast, Taarud og Østerås (2013) spør om hvordan vi kan få teori og praksis til å henge sammen i førskolelærerutdanningen. De drøfter 
dette ut fra tanken om at vi skaper mening i tilværelsen gjennom å fortelle om våre erfaringer, og de legger til grunn «et læringssyn som tar utgangspunkt $\mathrm{i}$ at studentenes kunnskap utvikles og etableres i sosial samhandling og i nær tilknytning til praksis» (s. 7). De peker også på noen kjennetegn ved teori-praksis-forholdet, som har avgjørende betydning for tilegnelse og utvikling av kunnskap (dialog, dialektikk, nærhet og avstand).

Utgangspunktet for Jordet og Roland (2012) er også forholdet mellom teori og praksis i en profesjonsutdanning, og her er praksis direkte knyttet til profesjonsutdanningens praksisopplæring og yrkesfelt: Hvordan få den teoretiske undervisningen på studiestedet og den praktiske undervisningen i yrkesfeltet til å henge bedre sammen? Jordet og Roland skriver at profesjonsutdanningene skal kvalifisere studenter til praktikere, som de forstår, med referanse til Tranøy, som «profesjonelle utøvere av vitenskapsbasert, verdiforankret og klientorientert virksomhet med velferd som mål» (s. 41). Forfatterne beskriver to prosjekter der feltene samarbeidet tettere og bidro gjensidig til kunnskapsutvikling og utveksling. Refleksjonene over den kunnskapen som yrkesfelt og studiested utvekslet og utviklet, framheves som «den meste læringsfremmende aktiviteten» (s. 40).

Schjølberg (2013) vil ha mer fokus på erfaringskunnskapens betydning, og forholdet mellom utdanning og yrke - innenfor økonomisk-administrativ utdanning. Han diskuterer erfaringsbegrepet, og forstår begrepet først og fremst i forhold til yrkespraksis. Han mener videre at forskningsbasert kunnskap (og undervisning) har høyere status og er lettere tilgjengelig, enn erfaringsbasert kunnskap. Schølberg hevder at skillet mellom disiplinfag og praktiske profesjonsfag, mellom teori/forskning og praksis/erfaring er uheldig og kunstig. Integrering, mellom teori og praksis og mellom forskning og erfaring, er hensiktsmessig, og praksisnær forskning i undervisningen gir dessuten muligheter for (student)aktive læringsformer.

Gjøsæter og Kyvik (2015) skriver, med bakgrunn i organisasjons- og ledelsesfag, om praksis forstått som yrkespraksis, og målet med undervisningen er at studentene utvikler en evne til å bruke sine teoretiske kunnskap i en relevant praktisk kontekst. De beskriver teoretisk og 
praktisk kunnskap med ord som: utenfra, del og «jeg-det»-kunnskap versus innenfra, helhet og «jeg-du»-kunnskap. De peker på betydningen av å utvikle refleksjons- og skjønnsevnen gjennom dybdelæring, hvilket innebærer at studenten utvikler sin selv- og virkelighetsforståelse og sin evne til å integrere det abstrakte og det konkrete.

Heimly og Bertheussen (2016) har også økonomisk-administrativ utdanning som bakteppe, og de deler mange av de samme synspunktene som Schølberg og Gjøsæther og Kyvik.

Jeg søkte også på nærliggende fraser som for eksempel erfarings-/praksisbasert kunnskap, men heller ikke disse nærliggende frasene avklares eller problematiseres i særlig grad. Det er imidlertid mange som er opptatt av erfaringsbasert kunnskap. De fleste tenker at dette er kunnskap som springer ut av praktiske yrkes- og livserfaringer, og denne kunnskapen stilles ofte opp som en motsetning til forskningsbasert eller vitenskapelig kunnskap. Sammenhengen eller forskjellen mellom erfaring og praksis problematiseres ikke. Ofte brukes ordene om hverandre, og den innforståtte betydningen er som oftest yrkeserfaringer eller yrkespraksis.

På Regjeringen.no får jeg til sammen tre treff på frasene praksisnær/ erfaringsbasert undervisning. Spørsmålet synes altså ikke å ha noen aktualitet hos myndighetene. La oss likevel gå litt dypere inn i dette og se på Meld. St.16 «Kultur for kvalitet i høyere utdanning» (2016-17) (Kunnskapsdepartementet, 2017), som er relevant i denne sammenhengen. Meldingen understreker at det må satses mer på forskning på undervisning og læringsprosesser, og at studieprogrammene må være forskningsbaserte. Undervisning og læringsaktiviteter må med andre ord bygge på kunnskap om hva som gir god læring. I Forskningsrådets innspill til meldingen pekes det på «at det finnes lite forskning på hva som gir kvalitet i høyere utdanning, spesielt knyttet til undervisning og læring» (Kunnskapsdepartementet, 2017, s. 102). Studieprogrammene må også bli relevante for arbeidslivet, og de bør utvikles i tett samarbeid med arbeidslivet og studentene selv. Dette er et av hovedmålene med meldingen, kan vi lese i forordet. I forordet sies det også at «kunnskap ikke er en vare som skal formidles og konsumeres» (Kunnskapsdepartementet, 2017, s. 3). Meldingen viser imidlertid at det er plenumsforelesninger og tradisjonelle eksamensformer som dominerer, og den slår fast at studentaktive 
læringsformer brukes for lite. Videre pekes det på - med henvisning til Studiebarometeret for 2015 - at studentene i liten grad er fornøyde med tradisjonell undervisning, veiledning og vurdering. Det kan her legges til at denne tendensen fortsetter i 2016 og 2017. I kapittel 3, som diskuterer hva som gir god læring, trekkes blant annet følgende fram: Studentene tilpasser seg de krav og forventninger som stilles, og de lærer når de får undervisning, tilbakemeldinger og vurderinger som aktiviserer og engasjerer. Meldingen legger til grunn at god formidling og god læring forutsetter et samspill mellom forskning, utdanning og praksis. Dette samspillet er mangefasettert. Både undervisningen - i bred forstand - og faget som formidles, skal bygge på forskning. Studentene bør gis mulighet til å ta del i et faglig fellesskap, og til å utvikle faglig nysgjerrighet, kritisk sans og selvstendighet. Studentene bør også ha kontakt med arbeidslivet og/eller annen virkelighet utenfor utdanningsinstitusjonen.

Jeg forstår det som her sies dit hen, at god læring eller rettere sagt: god undervisning, men uansett god kvalitet, oppnår vi når menneskets virkelighet og dets handlinger er naturlig integrert i undervisning og læring.

\section{Undervisningspraksis og læringspraksis}

Formålet med undervisningen er at noen skal lære noe. Men hva må til, hvordan må det gjøres, og hvorfor må det gjøres slik, er spørsmål mange undervisere stiller. Tanker om hvordan vi lærer, influerer undervisernes svar. Vi har sett at mange er opptatt av forholdet mellom teori og praksis i denne sammenhengen. Dette var også mitt ståsted da jeg gjorde et fokusgruppeintervju med en gruppe voksne studenter. Hensikten med intervjuet var å få en forståelse av hvordan studentene opplevde og erfarte sin egen læring, og gjennom dette kanskje kunne identifisere noen særtrekk eller kvaliteter ved læring.

Intervjuet er foretatt våren 2016 med en gruppe studenter som nettopp har avsluttet en toårig deltid videreutdanning. Klassen ble forespurt, og litt over en tredjedel (ti personer), meldte sin interesse. Materialet er basert på ett fokusgruppeintervju der fem av de ti deltok. Utvelgelsen av disse fem var praktisk: Det var disse fem den aktuelle datoen passet for. 
Deltakerne i intervjuet er fem voksne kvinner, alle profesjonelle helseeller sosialarbeidere. Intervjuet kan karakteriseres som åpent, i den forstand at det bare ble presentert ett tema eller ett spørsmål. Jeg ønsket at gruppen skulle snakke sammen om sine erfaringer med å lære. Deltakerne fikk snakke om det som falt dem inn der og da, men samtalen kretset i hovedsak rundt erfaringer fra de siste to årene. Intervjuet er tatt opp og transskribert. Intervjuet er slettet, og det inneholdt ikke opplysninger som "på noe vis kan identifisere enkeltpersoner, verken direkte eller indirekte», og det var derfor ikke meldepliktig. Jeg har foretatt en enkel kategorisering, tematisering og analyse ut fra en fenomenologisk-hermeneutisk innstilling og væremåte. Innstillingen kan beskrives som avventende og åpen (Halvorsen, 2011). Dette kan forstås slik: Vi forsøker å legge til side det vi allerede forstår og mener, altså vår forforståelse (Gadamer, 2007; Heidegger, 2007). Vi måtte sette forforståelsen i parentes, sa Husserl, slik at all vår oppmerksomhet rettes mot saken slik den viser seg for den enkelte (Zahavi, 2003). Mens vi anstrenger oss for å sette forforståelsen i parentes, må vi også akseptere at vi alltid er fortolkende. Kan vi stille krav til måten vi er på? Jeg mener ja. Kravet i en forskningsog forståelsesprosess er at vi må være mottakelige, refleksive og kritisk fortolkende (Halvorsen, 2011). Analyseprosessen er en dialektisk prosess der en går fra et umiddelbart helhetsinntrykk til enkelte meningsenheter som igjen speiles opp mot helheten. Framgangsmåten er inspirert av Lindseth og Norberg (2004, s. 149, 150), og er inngående beskrevet i Halvorsen (2011, s. 30-37).

\section{Praksis og teori i samspill}

Deltakerne beskriver sine læringsopplevelser i stor grad via fortellinger om, og refleksjoner over, forholdet mellom praksis og teori eller med noen andre ord: mellom det konkrete og det abstrakte. De forstår dette forholdet som dialektisk. De snakker om hvordan det konkrete og det abstrakte påvirker - og må påvirke - hverandre, for at ny kunnskap skal oppstå. Astrid sier for eksempel at «det er så mye lettere å forstå teorien hvis den henger sammen med noe jeg har erfart». Mens Bodil forteller om studentene som hun «har i praksis»: De er ferske, unge og de mangler 
denne spesifikke yrkeserfaringen. De har bare teoretisk kunnskap. Og det er interessant å observere hvordan de plutselig får en helt ny innsikt når de ser forbindelsen mellom det de erfarer, og det de har lest og hørt. Og dette bidrar også til ny kunnskap hos Bodil, som blir «påminnet teorien», og som nå ser den i en større og rikere sammenheng.

Flere av deltakerne snakker om hvordan nye teorier og begreper gir dem et nytt sted å se sine opplevelser, erfaringer og handlinger fra. «Gammel kunnskap fikk nye begreper som ga alt det jeg hadde av praksis en ny mening», sier Mette. «Ja, dette ble riktig for meg, og alt ramlet veldig på plass fordi de (begrepene) var så praksisnære», fortsetter hun. Hun beskriver hvordan begrepene utvider perspektivet: «Verden så litt annerledes ut; vi kom oss litt ut av den lille boksen og firkanten vi hadde vært i». Prosessen fram mot kunnskap kan ha utgangspunkt i det konkrete eller i det abstrakte, men, sier Trine, den må ha feste «i den virkeligheten jeg står i». «Et nøkkelord er kanskje at vi lærer når det er personlig meningsfylt», spør Catrine. Og Astrid fortsetter å spørre: «Handler det kanskje litt om å oppdage seg sjøl?» «Ja, jeg tror det», sier Trine, «og vi må være nysgjerrige, tørre å åpne opp, ha en mening, se og ville se». «Ja, ikke sant, stille seg noen spørsmål, og ikke bare dure av gårde», fortsetter Astrid.

Studentene opplever at de lærer når praksis og teori kommer i samspill. Teorien får mening og substans i møtet med konkrete erfaringer fra den enkeltes virkelighet, og den enkeltes virkelighet får nye dimensjoner når den forstås i lys av andres tanker, altså teorier.

\section{Praksisbegrepet}

Studentene her snakker om «praksis» som svarende til «yrkespraksis», men samtidig snakker de også om komplekse og integrerte erfaringer. Erfaringer som er dannet på bakgrunn av private, personlige og profesjonelle opplevelser. Ordet praksis, sa jeg innledningsvis, kan forstås slik: Praksis beskriver menneskets eksistensielle virkelighet og dets handlinger i denne virkeligheten. I en slik forståelse foreligger det både en værensdimensjon og en handlingsdimensjon. Disse to dimensjonene er etter mitt skjønn tydelig til stede i studentenes fortellinger om læringsopplevelser. 
Forholdet mellom nærhet og avstand til seg selv og egne erfaringer står sentralt i fortellingene. Bodil kaller det som skjer for en transformasjon: «Det er liksom så nært at jeg ikke får øye på det. Jeg må få det litt på avstand. Noen ganger blir jeg overrasket over at jeg ikke har sett det før.» Dette er et aktuelt tema. Gruppen snakker om «følelser», og det kan være emosjoner, fornemmelser eller tanker, og det diskuteres om hvorvidt disse «følelsene» gjør en blind eller om de fører fram til kunnskap. «Du må vel bli oppmerksom på de og så ta litt avstand fra de, for å se på de på nytt», sier Trine spørrende, og fortsetter: «for hvis du er i det, da vil du jo ikke kunne se det?»

Studentene sier at de lærer når de har kontakt med seg selv, mentalt og kroppslig, og nærmest samtidig får en avstand til seg selv slik refleksjonen kan få spillerom.

\section{Refleksjon}

Prosessen som er beskrevet ovenfor, kan i sin helhet kalles refleksjon. Jeg har valgt å forstå refleksjon på denne måten: Vi vender blikket mot oss selv og forsøker å få tak i inntrykket av uttrykket (for eksempel det vi ser, leser, hører), og samtidig vender vi blikket mot sammenhengen som vi og uttrykket inngår i, og forsøker å forstå den. For eksempel spør vi oss selv: Hva leser jeg, hvordan forstår jeg det jeg leser, og hvorfor forstår jeg det slik?

Min forståelse er inspirert av blant annet Skjervheim (1996), som diskuterer begrepet, og han spør - litt polemisk - om vi ikke først må undersøke hvor vi selv står, før vi undersøker andre? Men ikke ved å vende blikket innover, for der finner vi bare oss selv. Vi må rette blikket mot oss selv i en verden, altså i en sammenheng, sier Skjervheim. Dette kaller han refleksjon. Gjennom refleksjonen finner vi oss selv i en foranderlig og bevegelig situasjon (Halvorsen, 2009). Marcel (1958; 2001) kaller dette jeg her har beskrevet, for primær og sekundær refleksjon. Inntrykk eller opplevelser faller som oftest umiddelbart på plass i, og med, kjente kategorier og begreper. En opplevelse som ikke faller direkte på plass, vekker oppmerksomhet. I denne gjeninnføringssløyfen frigjør vi oss fra den umiddelbare erfaringen, og vi forsøker å gjenerobre innsikten i 
det konkrete (Knox, 2003). Hos Polanyi finner vi denne fornemmelsen av «noe som ikke stemmer», beskrevet som «den tause dimensjonen». Denne, sier Polanyi (2000, s. 93), «fungerer som en ledetråd til objektet for vår oppmerksomhet». Polanyi innfører også et skille mellom kunnskap som noe vi har, og noe vi er (tacit knowledge og tacit knowing). Han gjør dette for å vise forskjellen, men også for å framheve distinksjonen mellom kunnskap som passivitet og aktivitet, henholdsvis kunnskap vi har og er (Molander, 1996; Polanyi, 200o, s. 14). Også hos Heidegger og Gadamer er dette sentrale temaer. Heideggers påstand er at mennesket vanligvis vender seg bort fra seg selv og forfaller til tingene og de umiddelbare tankene. For å forstå oss selv og den verden vi lever i, må vi våge «å være» (Heidegger, 2007), eller sagt med Skjervheim (2002): Vi må våge å stå i et direkte forhold til oss selv. Det gjelder å få tak i hvordan vi «befinner oss» sier Heidegger (2007). Gjennom denne følelsen kan vi oppdage og forstå oss selv, de andre og verden vi lever i (Fløistad, 1993).

Gadamer er også opptatt av hvordan vi befinner oss, men kanskje enda mer opptatt av hvor vi befinner oss. Vi «ser» det vi forventer «å se», sier Gadamer, og for «å se noe» nytt, må vi stille oss undrende til det vi står overfor, og vi må flytte oss for å få nye perspektiver.

Skjervheim, Marcel, Polanyi, Heidegger og Gadamer diskuterer alle på hver sin måte - hvordan vi kommer fram til forståelse og kunnskap, og de synes alle å mene at menneskets eksistens og handlinger er grunnleggende i denne prosessen.

\section{Når liv og lære henger sammen}

Studentene trekker fram at det å «få ting til å henge sammen», som Astrid sier, altså at det å skape og å oppdage mening er en viktig læringsfaktor. Kunnskapstilegnelse er ikke en passiv hendelse, men en aktiv og kreativ virksomhet. Studentene beskriver en praksis - en tenkningens praksis - der de aktivt og på ulike måter arbeider med å forstå og tilegne seg kunnskap. Tilegnelsen skjer gjennom en åpen innstilling og en aktiv fortolkning. Flere av studentene beskriver gode læringsprosesser som en reise. Her kan de få følge av Marcel, som beskrev tenkningen som en vandring. En vandring sammen med den tenkende tanke (Kolstad, 
Langslet \& Aarnes, 1991). Med andre ord: en tanke som aldri er helt ferdig tenkt.

Studentene forteller og snakker sammen om situasjoner og opplevelser der de syntes at de lærte mye. Et fellestrekk er opplevelsene av sammenheng mellom egen virkelighet og lærestoffet, altså en sammenheng mellom liv og lære. Studentene opplever at det konkrete gir mening til, og får mening av, det abstrakte. De erfarer, som før nevnt, at egen virkelighet og praksis gjør teoriene meningsfulle, men de ser også at teoriene bidrar til en større forståelse av en kompleks virkelighet. Når vår virkelighetsforståelse henger sammen og blir meningsfull, oppleves dette som en bekreftelse og en anerkjennelse av vår virkelighetsforståelse. På denne måten styrkes vår selvforståelse og vår selvtillit, som igjen påvirker læringslysten. Et læringsmiljø som legger vekt på å skape meningsfulle, og dermed bekreftende, sammenhenger, synes også å fremme en kultur for slike handlinger. Studentene trekker fram opplevelser av bekreftelse og anerkjennelse som den viktigste læringsfaktoren.

\section{Sirkelen undervisning, læring og kunnskap}

Både litteraturundersøkelsen og studentintervjuene hjelper oss til å kretse det praksisnære inn på en mer presis måte. Det jeg mener især intervjuene bringer fram, er hvordan undervisningspraksisen er en særegen praksisform vi kan se i et produktivt lys. Betegnelsen praksisnær om denne undervisningspraksisen innebærer både normative og beskrivende elementer. Vi har noen mer og mindre avklarte tanker rundt spørsmålene hva praksisnær undervisning kan være, hvorfor vi ønsker slik undervisning, og hvordan vi kan gjennomføre den. Svarene vi gir oss selv og andre bygger blant annet på kunnskap og tanker om hva studentene skal lære, hva kunnskap er, hvordan læring skjer, og hvordan undervisningen må være for at læring kan skje (Raaheim, 2011). Forhåpentligvis har vi også noen erfaringer med, og tanker om, hvordan delene hva, hvorfor og hvordan henger sammen, og om, og eventuelt hvordan, de virker på hverandre. Erfaringer med, og tanker om, denne sammenhengen innebærer at vi også har erfaringer og tanker om forholdet mellom teori og praksis. 
Vi kan for eksempel tenke at dette handler om rekkefølge og nivåer. For eksempel slik at vi må vite at, eller hva, noe er og vi må lære ferdighetene og teknikkene, før vi kan forstå hvorfor og skjønne hvordan. Med denne tenkningen må vi først få faktakunnskapen overført og inn, og denne kunnskapen danner grunnlaget for å øve opp ferdigheter og teknikker. Vår forståelse av hvordan det hele henger sammen og virker sammen, hører her hjemme på et høyere, og mer avansert nivå. Vi kan bruke Blooms taksonomi fra 1956 (Raaheim, 2011, s. 67) til å illustrere denne tenkningen. I taksonomien, slik den tradisjonelt framstilles, tenkes det at vi lærer og utvikler oss intellektuelt i en bestemt rekkefølge. Det vil si fra en enkel til en avansert tenkning og forståelse, «der ferdighetene på ett nivå, forutsetter ferdighetene på et lavere nivå» (Raaheim, 2011, s. 66). Taksonomien brukes ofte for å kategorisere læringsmål, slik at de ulike nivåene knyttes til spesifikke læringsmål. Se for eksempel det nasjonale kvalifikasjonsrammeverket (Kunnskapsdepartementet, 2011). Nivåene (og læringsmålene) - der 1 er laveste nivå og 6 er det høyeste - er som følger (Gjøsæter, 2013; Raaheim, 2011):

1. faktakunnskap (å huske og å kunne gjengi innlært stoff),

2. forståelse (å forstå stoffet som er kommunisert, uten nødvendigvis å relatere det til noe annet,

3. anvendelse (å bruke teori for å løse et problem,

4. analyse (å kunne dele opp og se sammenhenger),

5. syntese (å trekke egne konklusjoner og slik skape ny kunnskap) og

6. vurdering (å kunne bedømme noe ut fra forskjellige kriterier).

Alternativt kan vi her tenke oss at læring dreier seg om erfaring, noe gjenkjennelig. Det kjente må vi utfordre ved å være nysgjerrige og undersøkende med hensyn til å finne ut hva som skiller seg fra det. Med denne tenkningen må vi snu på Blooms taksonomi, men kanskje også kaste litt rundt omkring på Blooms ulike kognitive fenomener: Vi vurderer fenomenet eller situasjonen vi står overfor - hvordan kan vi forstå dette, hva vet vi, hvordan kan vi dele det opp, og hvordan kan vi sette det sammen 
igjen og slik utvikle ny kunnskap? Dermed sprenger begrepet om praksisnærhet de snevre rammene som yrkespraksis byr på, og åpner et landskap som er eksistensielt betinget.

\section{Men hva er en erfaring?}

Dette er et uhyre komplekst og sammensatt spørsmål som mange tenkere har befattet seg med (Dewey, 2001; Gadamer, 2007; Heidegger, 1988; 2007; Polanyi, 2000). Jeg har selv forsøkt å forstå dette fenomenet. Jeg har spurt etter «erfaringens plass i tenkningen» (Halvorsen, 2011, s. 61), og jeg har forsøkt å forstå forholdet mellom opplevelse, erfaring og forståelse. Jeg beskriver sammenhengen som dialektisk og prosessuell, der det som stimulerer og driver prosessen, er hendelser og handlinger (Halvorsen, 2011). Jeg har også foreslått å skjelne mellom erfaring vi er og erfaring vi har (ibid.). Tanken fokuserer både på erfaringen som noe sanselig, kroppslig, emosjonelt og som noe avgrenset og kognitivt. Med ordet skjelne ønsker jeg å få fram at det ikke dreier seg om fenomener som er totalt atskilte. Det er snakk om å skjelne mellom deler i en helhet. Vi kan her snakke om deler som er implisitte og eksplisitte, eller tause og artikulerte (Polanyi, 200o), eller innvendige og utvendige (Østerberg, 1972), og som til sammen bringer inn ny forståelse og kunnskap. Vi kan også gå til for eksempel Løgstrup (1995a, 1995b) og Marcel (1958) for å få en større forståelse for forholdet mellom sansning og forståelse. Dette er kjernen, slik jeg ser det, i spørsmålet om erfaringens (eller praksisens eller livets) plass i tenkningen, og dermed i undervisningen og læringen. Vi opplever (Gadamer, 2007), sanser (Løgstrup, 1995a) og fornemmer når vi - med vår kropp - er (Heidegger, 2007), og vi forstår når vi kommer på avstand fra det sansede (Løgstrup, 1995a; Ricoeur, 1999). Kort sagt: Vi kjenner fordi vi er, og fordi vi kjenner etter, og vi gjenkjenner noe i det vi kjenner (Halvorsen, 2011). Eller kortere: Det dreier seg om forbindelsen og vekselvirkningen mellom «det å gjøre noe og det å gjennomgå noe» (Dewey, 2008, s. 203). Det å forstå og skape en helhet av forbindelsen mellom uttrykket, altså hendelsen og handlingen, og inntrykket, det er ikke bare tenkning, sier Dewey, men det er den mest krevende form for tenkning. 
La oss nå gå til Aristoteles og Østerberg for å videreutvikle vår forståelse av de sammenhengene jeg har skissert ovenfor.

\section{Tre virksomheter og deres kunnskapsformer}

Vi har tre former for menneskelige virksomheter, sier Aristoteles (1999): den teoretiske (theoria), den produktive (poiesis) og den praktiske (praxis). Virksomhetene bestemmes av ulike kunnskapsformer (ibid.): Til den teoretiske virksomheten hører viten (episteme), som gjerne omtales som sikker og sann kunnskap. Til den produktive og praktiske hører henholdsvis kunnen (techne) og klokskap (fronesis). Dette er viten om det som ikke er sikkert, og som derfor krever overveielse. I produktiv virksomhet overveier vi hvilket middel som er hensiktsmessig for å nå målet, mens vi i den praktiske overveier med hensyn til hva som er rett handling.

Aristoteles deler altså inn både det ene og det andre, men samtidig viser han konsekvent til hvordan alt henger sammen. Han deler for eksempel livet og det levende (psyche/sjelen) inn i ulike evner, men han beskriver likevel dette forholdet «som det krumme og det uthulede ved sirkelens omkrets» (Aristoteles, 1999, s. 16-17), altså som en helhet. Han mente også at alle kunnskapsformene (viten, kunnen og klokskap) måtte forenes med praktisk innsikt og fornuft (nous) (Aristoteles, 1999; Nilsson, 2009). Han beskriver med andre ord de tre kunnskapsdimensjonene ved livet, ikke bare som en helhet, men som dimensjoner som er nødvendige for - og som virker på - hverandre. Og legg også merke til at han omtaler alle kunnskapsformene som menneskelige virksomheter, altså som ulike praksiser. En annen måte å si dette på er at all forståelse, og dermed all kunnskap, er forankret i menneskelige virksomheter.

\section{Tre forståelses- og forankringsmåter}

Forståelse, sier Østerberg (1972), er innsikt i et saksforhold, og dreier seg om hvordan noe forholder seg til noe annet. Østerberg skiller mellom tre ulike (saks)forhold: utvendighet, identitet og innvendighet. I et utvendig forhold er delene uavhengige og uberørte av hverandre. De 
endrer seg ikke uansett hva som skjer med dem. I et utvendig forhold er også hver del eller hvert ledd identisk med seg selv. Perlene i et perlekjede er et eksempel fra Østerberg på utvendighet: Hver perle er en selvstendig enhet som ikke påvirkes eller endres av de andre perlene, mens tråden som binder dem sammen (på en bestemt måte; etter en regel, så å si), er et eksempel på identitet. Et annet eksempel er en klokke som skal repareres. Vi tar den fra hverandre, deler den opp, men vi må samtidig merke oss hvordan de enkelte delene forholder seg til hverandre for å kunne sette den sammen. Vi må finne regelen for forholdet mellom delene, og anvende den. Vi snakker her om det regelmessige: det samme skjer hver gang.

Jeg minner om at dette er forståelsesmåter. Virkeligheten er ikke så rendyrket. Det er nettopp poenget. Et eksempel på en utvendig tenkemåte i didaktikken kan være en streamet og nettbasert forelesning som studentene har tilgang til hjemmefra, og kun det. Studenten kan se den eller ikke se den. Graden av utvendighet henger sammen med hvorvidt studenten bare registrerer innholdet eller eventuelt tar det inn over seg og jobber med det. Evalueringsskjemaet med kategoriske svaralternativer som studentene fyller ut ved semesterslutt, er et eksempel på en identisk eller en regelmessig forståelsesmåte. Skjemaet er likt for alle. Det foreligger faste kategorier, og slik fylles det med andre ord ut etter en bestemt regel.

I et innvendig (saks)forhold er delene avhengig av hverandre. De utgjør en enhet, og de er ikke identiske med seg selv. Hver del må forstås ved den andre delen og ved helheten, og helheten må forstås ved hver del. Østerberg beskriver innvendighet som (1972, i Halvorsen, 2011, s. 9):

(...) en tenkemåte der sansningen kommer før begripelsen, samtidig som sansningen og begripelsen oppleves som ett. Når noe først er begrepet, er det som om begripelsen har vært der fra første stund, nærmest før sansningen. Begripelsen er der hele tiden, mener Østerberg, men den kan være latent (implisitt) eller manifest (eksplisitt). Overgangen mellom det latente og det manifeste er et tilfelle av forandring. Det dreier seg altså ikke om to uavhengige tilstander som på et ytre sett følger etter hverandre, men om en enhet og et indre, dialektisk forhold mellom det som forandres og det forandringen består i. Vi erfarer en forandring: Noe nytt framtrer. 
Forandringen eller overskridelsen hjelpes fram gjennom handling. Et eksempel på et slikt innvendig forhold er når vi arbeider med å uttrykke oss, når vi forsøker å klargjøre noe, når vi leter etter ord: «Mine ord viser meg hva jeg tenker på», sier Østerberg (1972, s. 70), «for mine tanker er ikke klarere enn min tale». Det er et innvendig forhold mellom den latente og den manifeste tanken. Det som hjelper tanken fram til klarhet, kan være å «ta ordet», tegne det, gjøre det, gå på biblioteket, slå opp, skrive, skrive på nytt, rette, stoppe opp, kjenne etter - kort sagt: være. Forutsetningene for denne forståelsesmåten er med andre ord: livet og virkeligheten.

Slik jeg forstår Østerberg, mener han at forståelsesformene er gjensidig utelukkende, og at de gjelder for spesielle områder, slik man også kan lese Aristoteles. Jeg mener imidlertid at alle tre kunnskapsformene gjør seg gjeldende når vi søker forståelse og kunnskap. Forskjellene kan vi knytte til hva som vektlegges, og hva som må vektlegges. Når vi forsøker å forstå et fenomen, abstrakt eller konkret, vil det være nødvendig både å dele opp, se etter likheter, mønstre og sammenhenger og forsøke å få øye på forandringen, altså det nye. Og det er det siste som representerer den egentlige forandringen: det nye (Gadamer, 2007; Østerberg, 1972). Denne forandringen får vi bare øye på når vi har kontakt med, og sanser, den tidligere kunnskapen eller erfaringen. I en oppdelt og regelmessig verden er dette ikke mulig. Forandringen er et indre forhold, sier Østerberg (1972, s. 63): «For vi har ikke her simpelthen to tilstander som etterfølger hverandre på en utvendig måte. Først én, så en ganske annen. Det er en enhet mellom det som forandres og det forandringen består i. Det er noe som har forandret seg.» Eller med mine ord: Forandringen er, eller rettere sagt: Vi er i en bevegelse og det skjer en forandring mellom opplevelse, erfaring, forståelse og kunnskap. Og det er særlig i virksomheter som krever overveielse - når vi må bestemme oss for hva som er godt og riktig å gjøre - at vi må utvikle en slik innvendig forståelsesmåte.

Østerbergs forståelsesmåter representerer ulike syn på kunnskap, og dermed også ulike syn på formidling, utvikling og tilegnelse av kunnskap. Inspirert av Østerberg har jeg valgt å omtale utvendig og identitet som et utenfraperspektiv, innvendig som et innenfraperspektiv, og til dette har jeg lagt et dialogisk perspektiv (Halvorsen, 2011). Med det dialogiske perspektivet er hensikten å peke på betydningen av å få en bevegelse 
i gang. En bevegelse som setter oss i kontakt med tidligere opplevelser, erfaringer, forståelser eller kunnskap. En bevegelse som også setter disse elementene i spill og på spill, slik at vi kanskje kan få øye det som skiller seg ut som noe nytt. Alle tre perspektivene er nødvendige. Men for å gjenta meg selv: Det er når vi er i eller lærer om virksomheter som krever overveielser - og særlig overveielser som angår det menneskelige - at de intersubjektive og interaktive elementene har avgjørende betydning.

\section{Hva kan praksisnær undervisning være - en foreløpig konklusjon}

Gjennomgangen av litteratur som omhandlet «praksisnær undervisning», viste at de fleste forfatterne med ordet «praksis» mener yrkespraksis. Undersøkelsen viste også at behovet for, og ønsket om, å utvikle det man omtaler som praksisnær undervisning ble begrunnet i forholdet mellom teori og (yrkes)praksis: Forholdet må bli tettere, og sammenhengen må bli tydeligere. Innledningsvis presenterte jeg en forståelse av frasen praksisnær undervisning som er langt bredere:

1. Praksis beskriver menneskets eksistensielle virkelighet og dets handlinger i denne virkeligheten. Praksis har med andre ord en værens- og en handlingsdimensjon.

2. Enhver forståelse eller læring bygger på ulike måter på disse to dimensjonene. Derfor bør all undervisning ha praksisnære elementer, hvilket betyr at det eksistensielle - eller livet og virkeligheten - inngår.

Jeg har snakket med noen studenter om læring, og det er min oppfatning at deres opplevelser styrker de to påstandene ovenfor. De opplevde å lære når teorien hadde feste i virkeligheten; i det konkrete - eller omvendt. De hadde erfart at læring var betinget av at teori og praksis eller det abstrakte og det konkrete samspilte tett. De hadde sett at teoretiske begreper og perspektiver ga ny mening til livet og virkeligheten, og omvendt, at livet og virkeligheten opplyste og oppklarte teori.

Jeg har også diskutert med andre som har tenkt på disse tingene. Heidegger har vist meg hvordan vi gjennom vår væren-i-verden kommer 
i kontakt med tidligere - og gjør nye - erfaringer. Gadamer er en viktig samtalepartner når det gjelder å forstå rekkevidden av at vi forstår og lærer gjennom erfaring. Og Aristoteles har hjulpet meg til å forstå praksis som alle de handlinger som er knyttet til menneskets ulike virksomheter, med andre ord både til det å tenke, produsere og samhandle. Fordi vi forstår og lærer gjennom erfaring, så må livet og virkeligheten inn i klasserommet, inn i auditoriene. Men vi må skape avstand til erfaringene dersom vi skal få øye på det allmenngyldige og det nye. Det er her læringen oppstår, i dette samspillet mellom nærhet og avstand, som i Østerbergs terminologi er et innvendig forhold, og som Ricoeur så flott beskriver som «forholdet mellom krefter og mening, mellom livet som bringer oss betydninger, og forstanden som kan kjede dem sammen i en koherent rekkefølge» (Ricoeur, 1999, s. 61).

\section{Litteratur}

Aristoteles. (1999). Den nikomakiske etikk. Oslo: Bokklubben dagens bøker.

Dewey, J. (2001). Erfaring og tenkning. I E. L. Dale (Red.), Om utdanning: klassiske tekster (s. 53-79). Oslo: Gyldendal akademisk.

Dewey, J. (2008). Å gjøre en erfaring: fra Art as experience (1934) (s. 196-213). Oslo: Universitetsforlaget.

Fløistad, G. (1993). Heidegger: en innføring i hans filosofi. Oslo: Pax.

Gadamer, H.-G. (2007). Sandhed og metode: grundtraek af en filosofisk hermeneutik. København: Academica.

Gjøsæter, Å. (2013). Praktisk erfaringskunnskap som aktivum for læreprosesser og læringsutbytte i organisasjons- og ledelsesstudier. Uniped [elektronisk ressurs]: tidsskrift for universitets- og høgskolepedagogikk, 36(2), 38-49.

Gjøsæter, Å. \& Kyvik, Ø. (2015). Er høyere organisasjons- og ledelsesstudier egnet for utvikling av reflekterte praksisaktører? Uniped [elektronisk ressurs]: Tidsskrift for universitets- og høgskolepedagogikk, 38(1), 39-52.

Halmrast, G. S., Taarud, R. \& Østerås, B. (2013). Bruk av praksisfortellinger for å skape sammenheng mellom praksis og teori i førskolelærerutdanningen. Norsk pedagogisk tidsskrift, (01), 17-27.

Halvorsen, G. S. (2009). Forståelsens konstitusjonelle betingelser. Refleksion $i$ praksis. Skriftserie Institut for filosofi og idéhistorie, Aarhus Universitet, Nr. 6, $1-28$.

Halvorsen, G. S. (2011). Relasjonen mellom hjelper og hjelpesøkende. Bodø: Universitetet i Nordland. 
Heidegger, M. (1988). Hvad betyder tænkning? Slagmark, 4-14.

Heidegger, M. (2007). Voren og tid. Oslo: Bokklubben.

Heimly, F. S. \& Bertheussen, B. A. (2016). Et forsøk på å integrere praksis i høyere økonomisk utdanning. Beta, 30(1), 29-41.

Jordet, H. \& Roland, L. R. (2012). Hvordan skape meningsfylte sammenhenger mellom «læring inne» og «læring ute» i sosialfaglig profesjonskvalifisering? Uniped, (02), 3242.

Knox, J. B. L. (2003). Gabriel Marcel: håbets filosof, fortvivlelsens dramatiker. Odense: Syddansk Universitetsforlag.

Kolstad, H., Langslet, L. R. \& Aarnes, A. (1991). Mysteriets tenker: Gabriel Marcel: en essaysamling. Oslo: Aventura; Bergen: i samarbeid med Bergens riksmålsforening.

Kunnskapsdepartementet. (2011). Nasjonalt kvalifikasjonsrammeverk for livslang læring (NKR).

Kunnskapsdepartementet. (2017). Meld. St. nr. 16 (2016-2017) Kultur for kvalitet i høyere utdanning.

Lindseth, A. \& Norberg, A. (2004). A Phenomenological Hermeneutical Method for Researching Lived Experience. Scand J Caring Science, 18(2), 145-153.

Løgstrup, K. E. (1995a). Ophav og omgivelse: betragtninger over historie og natur. Copenhagen: Gyldendal.

Løgstrup, K. E. (1995b). Vidde og prognans: sprogfilosofiske betragtninger. Copenhagen: Gyldendal.

Marcel, G. (1958). Eksistens og erkjennelse: betraktninger over det ontologiske mysterium. Oslo: Cappelen.

Marcel, G. (2001). The mystery of being: Vol. 1, Reflection \& mystery. South Bend, Indiana: St. Augustine's Press.

Molander, B. (1996). Kunskap i handling. Göteborg: Daidalos.

Nilsson, C. (2009). Fronesis och den mänskliga tilvaron. I J. Bornemark \& F. Svenaeus (Red.), Vad är praktisk kunskap? (s. 39-54). Huddinge: Södertörns högskola.

Polanyi, M. (200o). Den tause dimensjonen: en innføring i taus kunnskap. Oslo: Spartacus.

Raaheim, A. (2011). Loring og undervisning. Bergen: Fagbokforlaget.

Ricoeur, P. (1999). Eksistens og hermeneutikk. Oslo: Aschehoug i samarbeid med Fondet for Thorleif Dahls kulturbibliotek og Det norske akademi for sprog og litteratur.

Schjølberg, O. R. (2013). Erfaringsbasert undervisning i økonomisk-administrativ utdanning. Magma, 16(5), 31-39.

Skjervheim, H. (1996). Teknikk, politikk og utopi. Oslo: Aschehoug.

Skjervheim, H. (2002). Mennesket. Oslo: Universitetsforlaget. 
Stern, D. N. (2007). Her og nå. Oslo: Abstrakt forlag.

Sæverot, H. (2015). Didaktisk fornyelse? I P. O. Brunstad, S. M. Reindal \& H. Sæverot

(Red.), Eksistens og pedagogikk: en samtale om pedagogikkens oppgave (s. 125-137).

Oslo: Universitetsforlaget.

Zahavi, D. (2003). Fenomenologi. Frederiksberg: Roskilde Universitetsforlag. Østerberg, D. (1972). Forståelsesformer: et filosofisk bidrag. Oslo: Pax. 


\title{
KAPITTEL 3
}

\section{Psykologisk kontrakt med studenter i høyere utdanning}

\section{Gisle Heimly, Egil Eide og Njål Vidar Traavik}

Høgskulen på Vestlandet

\begin{abstract}
In this article, we present how a shared psychological contract was negotiated with students at the Practical Pedagogical Education for Vocational Teachers (PPU-Y) at the beginning of the program, autumn 2016. A modified version of the nominal group technique (NGT) was used in groups and in whole class negotiations. General themes representing the individual students as well as common expectations of the role of the teacher and their own role as students were identified.

The findings show that the students have a high degree of relational expectations to the teacher, expect structure and predictability in the study, and expect relevance between education and objectives of education and that individual expectations to the teacher and the negotiated psychological contract in class are relatively similar.
\end{abstract}

Keywords: psychological contract, teacher-student relations, role expectations, nominal group technique (NGT)

\section{Introduksjon}

Når studenter møter til et studium, er det viktig å avklare hvilke forventninger lærerne har til studentene. Vi vil argumentere for at studentene på sin side bør bli klar over de forventningene de har til studiet, lærerne, medstudenter og seg selv. En slik gjensidig avklaring mener vi å kunne oppnå med å etablere en psykologisk kontrakt mellom de to partene. Undersøkelser viser at første års studenters forventninger til høyere utdanninger kan være svært forskjellige. Enkelte forventer en tradisjonell forelesning med enveiskommunikasjon i større forelesningsgrupper (Sander, Stevenson, King \& Coates, 2000). Andre forventer heller ter i høyere utdanning. I Y. T. Nordkvelle, L. Nyhus, A. Røisehagen og R. H. Røthe (Red.), Praksisnor undervisning - i praksis og teori (Kap. 3, s. 53-66). Oslo: Cappelen Damm Akademisk. https://doi.org/10.23865/ noasp.94.ch3. Lisens: CC BY 4.o. 
det dialogpregede klasserom der toveiskommunikasjonen preger forelesningssituasjonen (Deakin, McCombs \& Haddon, 2007). Tradisjonelt kan det hevdes at student-lærer-rollen er preget av enveiskommunikasjon der studenten er passiv mottaker av kunnskap, selv om lytting og mental bearbeiding av forelesning kan være en omfattende aktivitet i seg sjøl. Regan hevder at «stemmen til både lærer og student bør være involvert i forhandlingene i den psykologiske kontrakten om studentene skal bli hørt» (Regan, 2012, s. 16). Hun viser videre til at studentene trenger å diskutere forventningene til hverandre grundig. Dette gjør det mulig for begge parter å gi hverandre en mulighet til å virke inn på, definere og forme innholdet. Det hjelper dem også til å komme frem til og vedta en gjensidig akseptabel avtale. Fordelen med å be studentene om å artikulere sine egne rolleforventninger og forventninger til lærer og til egen utdanning er at det kan redusere usikkerhet, øke bevisstheten om urimelige eller misforståtte forventninger, og sette scenen for å etablere felles kjøreregler for lærer-student-forholdet. Den psykologiske kontrakten kan da sees på som et verktøy for å heve studiekvaliteten der det skapes en intersubjektiv forståelse for selve undervisningens form og innhold.

Undersøkelser viser òg at enkelte studenter beveger seg mot en konsumentholdning som gjenspeiler en instrumentalistisk holdning til det å studere (Regan, 2012). Med andre ord: Bytteverdien av studiet er mer interessant enn bruksverdien. Forventning til studentrollen er da en passiv studentrolle der lærer forventes å servere kunnskap til studenten der denne inntar en «kost-nytte»-holdning overfor utbytte av forelesningen. James (2002) sin forskning viser at studentenes førsteinntrykk og erfaringer som student kan være viktig i forhold til de forventningene som skapes hos studenten i videre studier. Han trekker fram størrelsen på studentgruppen som viktig for å skape gode personlige relasjoner til studentene. I store klasser er sjansen for å miste engasjement og nærhet til studenten større (James, 2002; Bunce, Baird \& Jones, 2016).

\section{Forventninger hos lærer}

I en psykologisk kontrakt er det et tosidig forhold, der studentene utgjør den ene parten og lærer den andre parten, og der begge spiller en rolle i 
forhold til hverandre. Ramsden (2008) viser til at lærerne ofte har klare forventninger i forhold til oppnåelse av læringsutbytte hos studenten. Disse er uttrykt gjennom de formelle læringsutbyttebeskrivelsene i emnebeskrivelser og uformelle læringsmål gitt i en undervisningssituasjon.

Mål og vurdering henger tett sammen, og det kan være læringsmessig fornuftig å se disse i relasjon til hverandre. Det kan derfor være hensiktsmessig å også diskutere vurderingsformene sammen med målene slik at forventningene til læringsarbeidet og læringsresultat sees i sammenheng. Dette kan gi klarerere retning for studentens arbeid og være med på å styrke studentens mestringsforventning (Ramsden, 2008). Det er en antakelse at undervisningskvaliteten kan bedres ved å redusere gapet mellom lærer sine forventninger og studentens forventninger. I dette ligger det ikke bare forventninger i forhold til mål og vurderinger, men også f.eks. forventninger til oppmøte, om å møte forberedt til undervisningen eller delta i klassediskusjoner (Ramsden, 2008).

\section{Roller}

Rolleforståelsen blir viktig å få fram der denne kan defineres som forventet adferd til noen som har en bestemt stilling innenfor en bestemt sosial setting og der rollen er knyttet til en bestemt posisjon i en gitt sammenheng. I teorier om sosiale roller er det viktig å forstå samspillet mellom forventninger og atferd. En rolle er knyttet til en bestemt posisjon i en gitt sammenheng, og en forventet atferd fra rollens utøver er gitt når man vet hva egen og andres rolle kan gå ut på (Robbins, Judge, Odendaal \& Roodt, 2009). Når innehaverne av rollene er usikre på forventningene, blir rolleforståelsen tilsvarende usikker. Uklare og lite uttrykte rolleforventninger skaper usikkerhet i forhold til forventet atferd (Pekdemir, Koçolu \& Gürkan, 2013). Noe lignende kan en se hos Ask Burlefot, hovedpersonen i Agnar Mykles sin bok fra 1956, «Sangen om den røde rubin». Ask blir overrasket og til dels indignert over dosentene og professorenes «drøvtygging» av pensum når han som fersk student begynner å studere økonomi. Hans forventninger til høyere utdanning er langt fra det han møter både hos lærerne og medstudentene, der alle synes å ha en materialistisk karriereinnstilling til utdannelsen. Ask føler dermed på en 
forvirring og usikkerhet rundt sin egen rolle i studiesituasjonen (Mykle, 1956, s. 62).

Hensikten med psykologiske kontrakter er å artikulere rolleforventningene og skape konsensus om innholdet mellom partene. En av forutsetningene for bruk av psykologiske kontrakter er at denne utvikles gjennom dialog og kontinuerlige reforhandlinger og evalueringsmøter. I motsetning til andre forståelser av begrepet kontrakt er den psykologiske kontrakten dynamisk og forandrer seg gjennom dialogen mellom lærer og student (Herriot, Manning \& Kidd, 1997). En kan derfor se på den psykologiske kontrakten som en intersubjektiv forståelse mellom lærer og student som avklarer de ulike rolleforventningene mellom de to (Clinton, 2009).

\section{Psykologisk kontrakt}

Psykologisk kontrakt er et konsept utviklet hovedsakelig innenfor organisasjonspsykologien, der den handler om forholdet mellom arbeidsgiver og arbeidstaker (DelCampo, 2007). Denne artikkelen tar opp den psykologiske kontraktens potensielle rolle i høyere utdanning. Vi vil undersøke hvordan den psykologiske kontrakten kan bli et verktøy for å avklare det sosiale forholdet mellom student og lærere. Dette forholdet blir blant annet konstruert av den oppfattede og gjensidige forståelsen mellom lærer og student. Det er i dette forholdet det ofte ligger implisitte og eksplisitte forventninger. Det blir da et poeng å få fram de forventningene som eksisterer mellom student og lærer. Dette kan en for eksempel gjøre ved å fokusere på rolleforventninger og verdisyn som ligger til grunn for de forventningene som eksisterer.

Studentens forventning til egen mestring av studiene vil kunne forme studentrollen i det bytteforholdet som eksisterer i et læringssamarbeid. Bruk av psykologisk kontrakter ble først introdusert av Argyris (1960) som gjensidige forventningsavklaringer mellom leder og ansatt der de implisitte forventningene ble funnet å påvirke den ansattes arbeidsinnsats. Rousseau (1990) skiller mellom to typer psykologiske kontrakter med hensyn til kontraktens innhold, transaksjonell (fra latin transigere «drive gjennom» og agere «sette i bevegelse») og relasjonell kontrakt. Den transaksjonelle kontrakten inneholder et bytteforhold som ofte er koblet opp mot økonomi, 
for eksempel arbeidsinnsats og belønning. Den relasjonelle kontrakten er mindre knyttet opp mot et konkret bytteforhold. Den er dynamisk og henspiller på relasjonelle forhold basert på et følelsesmessig engasjement. Dette kan f.eks. være lojalitet, forpliktelse, tillit og utviklings- og opplæringsmuligheter (Rousseau, 1990; Aselage \& Eisenberger, 2003; Yan \& Zhu, 2013). En psykologisk kontraktsforbindelse mellom mennesker (Morrison \& Robinson, 1997; Herriot, 1992) der dialogen vil stå sentralt, kan dermed skape en emosjonell relasjon. Etzioni (1961) hevder at en dialog ikke kan foregå i et møte hvor maktforholdet ikke er avklart eller diskutert. Rolleavklaring av maktposisjonen i et arbeidsfellesskap skaper sikkerhet og forutsigbarhet dersom deltagerne i arbeidsfellesskapet eksplisitt kan uttale seg, sikre innbyrdes nytte og forståelse for rollene og dermed forståelse for kontrakten. Den psykologiske kontrakten skaper dermed en felles forståelse som binder partene til en bestemt måte å handle på. Det er disse aspektene av den psykologiske kontrakten mellom lærer og student som kan være med på å fremme studentens motivasjon og prestasjon (Ullah \& Wilson, 2007). Den psykologiske kontrakten kan derfor være et praktisk verktøy til å avklare forventningene mellom student og lærer (Clinton, 2009). Flere undersøkelser viser at vektleggingen av det relasjonelle forholdet mellom student og lærer gjør studenten mer tilfreds med studiet, oppmuntrer til $ø$ kt studentaktivitet, øker motivasjon for studiet og bidrar til et positivt læringsmiljø (Clinton, 2009; Pietersen, 2014). Når det gjelder psykologisk kontrakt som verktøy for å fremme disse relasjonene i høyere utdanning, er det ifølge Pietersen meget begrenset forskning, også internasjonalt (Pietersen, 2014). Vi har ikke funnet forskning i Norge som viser resultater fra forsøk med å etablere en fremforhandlet psykologisk kontrakt som underskrives av både studentgruppe og lærer. Ved å forhandle fram en felles psykologisk kontrakt gir en studentene mulighet for samarbeid med lærer og sine medstudenter der studenten får anledning til å uttrykke sine forventninger til lærer. Med denne bakgrunnen ville vi gjøre forsøk med bruk av en psykologisk kontrakt mellom student og lærer i høyere utdanning, både individuelt og i klassesammenheng. Pietersen (2014) refererer i sin artikkel «Negotiating a Shared Psychological Contract with Students» til flere kilder som beskriver forhold knyttet til psykologiske kontrakter med studenter. For det første viser hun til Perlman og McCanns (1999) forsøk 
der de ba sine studenter beskrive de mest nyttige ting lærerne kunne gjøre ved oppstart av et studieår. Den hyppigst nevnte nyttige atferd var at lærer gav detaljert informasjon om kursinnhold og krav, og avklarte forventninger. De konkluderte med at det avgjørende tidspunktet i lærer-studentforholdet er oppstart av første semester i utdanningen. Dernest viser hun til Bryson, McDowell, McGugan og Sanders (2011) sin forskning om førsteårsstudenter. Den viser at de affektive aspektene ved deres møte med høyere utdanning er veldig undervurdert. De opplever ofte at elementer som er viktige i en psykologisk kontrakt, som engasjement, tilfredshet og lojalitet, ikke følges eller brytes. Videre peker hun på forskning som viser at avklarte roller som oppleves som rimelige og rettferdige, fremmer nettopp tillit og lojalitet (Fox, 1974; Wilkens \& Nermerich, 2011). Det motsatte oppstår når studentene opplever urettferdighet. Da møtes urettferdigheten med svekket tillit og brudd på etablerte kontrakter. Det er derfor det er viktig å forhandle fram en kontrakt studenter og lærere kan respektere og innfri (Jafri, 2012).

I denne studien ble det fokusert på å:

- Identifisere studentenes forventninger til studiet og forventningene til lærer sin rolle

- Kategorisere en klasse sine fremforhandlede felles forventninger til studiet og lærerens rolle.

\section{Metode}

Den grunnleggende ideen bak denne studien er at studentenes stemme skal bli hørt når gjensidige rolleforventninger knyttet til lærer-studentforholdet blir forhandlet frem i dialog og underskrevet som en skriftlig avtale mellom studentene (klasse og kull) og lærer(e).

En modifisert versjon av den nominelle gruppeteknikken (NGT), utviklet av Delbecq og Van de Ven (1971), ble brukt for å skaffe individuelle og grupperte data og for å få enighet i gruppen gjennom forhandlinger om innholdet i en felles psykologisk kontrakt.

NGT er en mixed-method-tilnærming for å samle både kvalitative og kvantitative data og for å nå gruppe-konsensus (Potter, Gordon 
\& Hamer, 2004). En enkel casestudie ble brukt til å samle kvalitative data fra 24 yrkesfaglærerstudenter. Studentene er fagutdannet innenfor yrkesfaglige studieretninger. De fleste studentene har oppnådd bachelorgrad eller tilsvarende. Klassen bestod av 15 kvinner og 9 menn, n = 24, alle over 25 år.

Forhandlingsprosessen ble gjennomført i seks faser:

1. Kartlegge individuelle forventninger til lærer og til studiet.

2. Kartlegge forventningsavklaringer i gruppe (5-6 studenter) som forhandler om og rangerer forventningene 1-9 (1 høyest, 9 lavest).

3. Kartlegge forventningsavklaringer i storgruppe (10-12 studenter) som forhandler om og rangerer forventningene 1-9 (1 høyest, 9 lavest).

4. Plenumfremlegg, hvor storgruppene legger frem sine rangerte forventninger, og forhandler med mål om å komme frem til en felles rangert (1-9) forventningsavklaring for alle studentene i klassen.

5. Lærer legger frem sine forventninger til studentene, og forhandler med studentene om en rangert forventningsavklaring.

6. Gjensidig forventningsavtale/kontrakt blir underskrevet av studenttillitsvalgte og lærer.

Data fra forhandlingsprosessens faser ble samlet inn fortløpende under prosessen. Forskningsmetodisk støttes og anbefales denne datainnsamlingsmetoden av Fisher og Miller (2008), Thorne (2000) og Pietersen (2014).

De innsamlede dataene ble analysert kvalitativt. Ifølge Creswell (1994) er det ingen enkel metode for analyse av kvalitative data. I stedet dikterer formålet med en studie hvilken metode man velger. I denne studien brukte vi en induktiv tilnærming til å kondensere individuelle svar i generelle temaer. Thomas (2006) viser til at to av hovedformålene ved å bruke en induktiv tilnærming er å redusere varierte rå tekstdata gjennom gjentatt undersøkelse og sammenligning i et sett av kategorier, og å etablere klare koblinger mellom forskningens mål og oppsummeringsresultater 
fra rådata. De naturlige meningsenhetene vi fant, ble gruppert i generelle temaer som synes å være felles for alle studenters beskrivelser. Utdrag av studenters verbale kommentarer brukes i denne artikkelen til å belyse forskningsspørsmålene.

\section{Resultat og diskusjon}

Studentenes individuelle forventninger til lærer (tabell nr. 1) er kategorisert i 3 temaer: form, innhold (transaksjonelle forventninger) og relasjonelle forventninger. Tabell 2 er kategorisert som form og transaksjonelle forventninger (innhold).

I form kategoriseres studentenes forventninger knyttet til læreren, utdanningsstruktur og innhold.

Under transaksjonelle forventninger er studentenes forventninger kategorisert ut fra uttrykte utsagn til ferdigheter til læreren og innhold og struktur på studiet.

Relasjonelle forventninger er kategorisert ut fra utsagn om samspill, respekt og relasjoner og hvorvidt de oppleves som positive, energigivende og konstruktive.

Tabell 1. Studentenes individuelle forventninger til lærer.

\begin{tabular}{|c|c|c|}
\hline Form & $\begin{array}{l}\text { Innhold (transaksjonelle } \\
\text { forventninger) }\end{array}$ & Relasjonelle forventninger \\
\hline $\begin{array}{l}\text { 1. God formidler } \\
\text { 2. Inspirerende } \\
\text { 3. Engasjerende } \\
\text { 4. Variert undervisning }\end{array}$ & $\begin{array}{l}\text { 1. Faglig oppdatert } \\
\text { 2. Relevant } \\
\text { 3. Gi eksempler fra praksis }\end{array}$ & $\begin{array}{l}\text { 1. Vise respekt } \\
\text { 2. Være forberedt } \\
\text { 3. Være imøtekommende } \\
\text { 4. Møter presis } \\
\text { 5. Overholde pauser og timer } \\
\text { 6. Gi klare og tydelige beskjeder } \\
\text { 7. Har humor } \\
\text { 8. Kan styre diskusjonene } \\
\text { 9. Svarer raskt på e-post }\end{array}$ \\
\hline
\end{tabular}

Tabell 2. Studentenes individuelle forventninger til studiet.

\begin{tabular}{|c|c|}
\hline Form & Innhold (transaksjonelle forventninger) \\
\hline $\begin{array}{l}\text { - } \quad \text { Holder seg til oppsatte planer } \\
\text { - } \quad \text { Forutsigbart studium med god struktur } \\
\text { - } \quad \text { Gode lokaler og utstyr } \\
\text { - } \quad \text { God dialog med lærerne } \\
\text { - } \quad \text { God og relevant litteratur }\end{array}$ & $\begin{array}{ll}\text { - } & \text { Lære å undervise } \\
\text { - } & \text { Bli en god lærer } \\
\text { - } & \text { Kunne bruke teorien i praksis som lærer } \\
\text { - } & \text { Elevkunnskap } \\
\text { - } & \text { Lærer å tilpasse / differensiere undervisning }\end{array}$ \\
\hline
\end{tabular}


Tabell 3. Klassen sine fremforhandlede prioriterte forventninger til læreren.

1. Lærer er punktlig og godt forberedt.

2. Lærer er kunnskapsrik og faglig kompetent.

3. Lærer er motiverende og engasjerende.

4. Læreren gir veiledning når det trengs.

5. Tydelig kommunikasjon på alle plan.

6. Lærer buker de metoder som han underviser om.

7. Utfordrer og lar studentene få prøve seg.

8. Gir ærlige tilbakemeldinger.

9. Tillater noe diskusjon, men setter en grense.

Tabell 4. Klassen sine fremforhandlede prioriterte forventninger til studiet.

1. Læringsmetoder som er forskningsbasert og relevant

2. Opparbeide pedagogisk forståelse i tråd med plan for studiet

3. Tilegne oss god og formell kompetanse til læreryrket

4. De ytre rammene er egnet for formålet.

5. Yrkesetikk og elevers rettigheter.

6. Struktur og rammer er tilpasset at studentene er i full jobb.

7. Forventningsavklaring med praksisplass er utdelt i god tid.

8. Bevisstgjøre og trygge studenter i et valg om å bli lærer.

9. Gjøre oss i stand til å se den enkelte elev.

Tabell 5. Lærer og klassen sine fremforhandlede prioriterte forventninger mellom lærer og studentgruppe.

1. Gjensidig respekt / god dialog og tillit

2. At studentene samarbeider for tilrettelegging av kvalitet og effektivitet i læringsarbeidet

3. At studentene tar ansvar for egen læring

4. At studenter og lærer møter faglig forberedt til forelesninger, studentpresentasjoner og praksis

5. Studenter og lærer møter presist til samlingene

6. Lærer og studenter samarbeider om faglig opplegg

7. Lærer og studenter utarbeider i fellesskap fornuftige regler for bruk av PC, mobiltelefon, studentaktivitet.

8. Lærer og student holder seg oppdatert på itslearning og e-post

9. Aktiv deltagelse i diskusjoner i storgruppe, klasse og gruppeaktiviteter

Den forhandlede psykologiske kontrakten inneholder en blanding av krav til innhold og struktur, transaksjonelle og relasjonelle forventninger. Disse funnene støtter Koskina (2013) og Pietersen (2014) sine funn om forventningene som inngår i en utvekslingsavtale mellom studenter, deres veiledere og deres læringsinstitusjon. Studentens individuelle forventninger til lærer innenfor den relasjonelle kontraktstypen er i flertall. De har en forventning om at læreren er imøtekommende, viser respekt og svarer raskt på e-posthenvendelser. Men også didaktiske egenskaper hos lærer er klart formulert i studentenes forventninger. Studentene har 
forventninger om at lærer formidler fagstoffet på en inspirerende måte, er engasjerende og at det er variasjon i hvordan fagstoffet blir formidlet. Studentene har også transaksjonelle forventninger til at teori eksemplifiseres med praksis. En av studentene formulerer sin forventning slik: «Forventningen min er at undervisningen er relevant med tanke på praksis». En annen student har forventning om at lærer «gir gode eksempler fra praksis og er engasjert». Relevans til fremtidig yrkesutøvelse som yrkesfaglærer er sterkt poengtert i studentenes transaksjonelle forventninger. Våre funn støttes av Kember, Ho og Hong sin undersøkelse (2008), som fant at for studenter fra ni ulike studieprogrammer ved tre forskjellige universiteter i Hong Kong så var de viktigste virkemidlene for å motivere til læring å etablere relevans. Dersom læringen skulle gi mening, måtte det etableres en koherens mellom studenten og «real-world». Videre hevder Kember, Ho og Hong (2008) at en nøkkelfaktor er å gi studentene en læringskontekst der studentene konstruerer sin egen relevans og forståelse av innholdet, noe som i yrkesfaglig lærerutdanning kan knyttes til den enkeltes fagområde og didaktisk og yrkespedagogisk mestringsforventning.

Resultatet av vår kartlegging viser at studentene gjennom forhandlingsprosessen fra individuell - til gruppe - til klasse følger opp sine transaksjonelle forventninger til studiet. Noen av studentene kommenterte det slik: «lære å undervise», «bli en god lærer», «kunne bruke teorien i praksis som lærer».

Studentenes svar tilsier at de vil lære lærerprofesjonen gjennom meningsfull og relevant undervisning hvor lærer har fagkompetanse og god struktur (form) på det didaktiske opplegget. «Holder seg til oppsatte planer», «forutsigbart studium med god struktur» går igjen i studentresponsene.

Studentenes individuelle forventninger viser at de ikke har tydelige forventninger om å påvirke studieopplegget. Dette samsvarer med studentrollen som en «konsument» med en kost-nytte-innstilling til studiet som også er beskrevet av James (2002) og Sander, Stevenson, King og Coates (2000).

Det fremkommer at studentene, både individuelt og i klasse, har forventning om at læreren styrer diskusjonene i undervisningen. Dette indikerer at studentene forventer at en som lærer åpner opp for diskusjoner 
og kan lede disse. Dette kan sees som et uttrykk for maktforholdet mellom lærer og student. En student formulerer sin forventning om at lærer «forholder seg saklig og unngår unødvendige diskusjoner». Lærerens forventninger til studenter gjenspeiles mye i den fremforhandlede psykologiske kontrakten med klassen sine forventninger. Dette kan tyde på at det er en felles forståelse mellom lærer- og studentrollen og at klassen samlet sett har tradisjonelle forventninger til det relasjonelle forholdet mellom lærer og student. Den fremforhandlede psykologiske kontrakten for hele gruppen/klassen (nr. 4 i forhandlingsprosessen) viser en blanding av transaksjonelle og relasjonelle forventninger. Dette støttes av tidligere forsøk med bruk av psykologiske kontrakter (Koskina, 2013; Pietersen, 2014). Undersøkelsen viser også at den framforhandlede kontrakten i klassen ikke skiller seg vesentlig ut fra studentenes individuelle forventninger. Dette støttes av tidligere fors $ø \mathrm{k}$ (Pietersen, 2014) og reiser spørsmålet om det er nødvendig å bruke tid på individuelle kontrakter og deretter til klasseforventninger, men i stedet gå rett på å forhandle fram en klassekontrakt som er skriftlig, underskrevet og tilgjengelig for alle.

\section{Oppsummering}

Vår studie viser at studentene har både transaksjonelle og relasjonelle forventninger til læreren, i tillegg til at lærerne viser relevansen av det de lærer, for et framtidig yrke som lærer. Dette kan sees i sammenheng med at studentene har klare forventninger om at tiden de bruker i interaksjon med lærer, skal være mest mulig effektiv i forhold til læring, samtidig som de ønsker en relasjon til lærer, bl.a. for å kunne påvirke det transaksjonelle forholdet mellom seg selv og lærer. Ved å bruke psykologiske kontrakter i undervisningen som redskap for å klargjøre en felles forståelse av forholdet mellom student og lærer, vil dette kunne øke læringen (Clinton, 2009; Pietersen, 2014).

I den videre forsking vil et mulig fokus være å se nærmere på om effekten ved bruk av psykologiske kontrakter påvirker studentenes læringsutbytte. Det vil også være interessant å se på effekten ved bruk av gjensidig forventningsavklaring brukt i mindre studentgrupper i prosjektarbeid og liknende. Våre funn støtter ideen om å forhandle fram en 
felles psykologisk kontrakt i stedet for en enkelt kontrakt med hver enkelt student. De spesifikke rettigheter og plikter i den delte psykologiske kontrakten gjenspeiles i uttrykte forventninger til hverandre. Lærere kan derfor spare tid ved å forhandle fram en felles enighet. Prosessen med å be studentene om å uttrykke for seg selv, sine medstudenter og deres lærer hva deres forventninger er i begynnelsen av et nytt studieår, gir en god mulighet for lærere til å reflektere over hvordan man kan tilpasse sin atferd for å optimalisere sitt forhold til sine studenter. Det gir også en første mulighet til å demonstrere for studenter at lærere er villige til å lytte til deres stemme. For studenter gir det en sjanse til å reflektere over hva de ønsker fra lærer-student-forholdet, og å ta eierskap og medansvar for sin atferd i forholdet. Den psykologiske kontrakten bør tas opp etter endt semester, og reforhandles. Derved kan en regulere og styrke de gjensidige rolleforventningene i lærer-student-forholdet samt korrigere forventningene. Det er ofte neglisjert innen høyere utdanning av at lærere og studenter kan danne sosiale relasjoner som kan påvirke studiekvaliteten. Dette skjer på tross av at enkelte studenter inntar en «kost-nytte»-holdning overfor undervisningen. Agnar Mykles (1956) beskrivelse av Ask Burlefot sin oppfattelse av professoren som en som kan sitt fag, holder seg bak kateteret og som «har motet til å bli mislikt av sine studenter», kan kanskje være mer reell enn en tror. Den psykologiske kontrakten kan da være et viktig verktøy for å håndtere dette forholdet.

\section{Referanser}

Argyris, C. (1960). Understanding organizational behavior. Oxford, England: Dorsey. Aselage, J. \& Eisenberger, R. (2003). Perceived organizational support and psychological contracts: A theoretical integration. Journal of Organizational Behaviour, 25(5), 491-509.

Bryson, C., McDowell, L., McGugan, S. \& Sanders, G. (2011). A relationship heading for divorce? Assessment, trust and student engagement. Hentet 20/01/2014 fra http://www.brookes.ac.uk/aske/documents/bryson_mcdowell.pdf

Bunce, L., Baird, A. \& Jones, S. A. (2016). The student-as-consumer approach in higher education and its effectson academic performance. Studies in Higher Education, 42(11), 1958-1978. Hentet 12/02/2017 fra https://doi.org/10.1080/030750 79.2015.1127908 
Clinton, M. (2009). Managing student's and teacher's expectations of higher education: A psychological contract approach. School of Social Science and Public Policy, King's College London.

Creswell, J. W. (1994). Research design: Qualitative and quantitative approaches. Thousand Oaks: Sage.

Deakin, C. R., McCombs, B. \& Haddon, A. (2007). The ecology of learning: Factors contributing to learner centred classroom cultures. Research Papers in Education, 22(3), 267-301. Hentet 02/04/2014 fra https://doi.org/10.1080/02671520701497555

Delbecq, A. L. \& Van de Ven, A. H. (1971). A group process model for problem identification and program planning. The Journal of Applied Behavioral Science, 7(4), 466-492. Hentet 11/o9/2014 fra https://doi.org/10.1177/002188637100700404

DelCampo, R. G. (2007). Understanding the psychological contract: A direction for the future. Management Research News, 30(6): 432-440.

Etzioni, A. (1961). A comparative analysis of complex organizations. New York: The Free Press.

Fisher, R. \& Miller, D. (2008). Responding to student expectations: A partnership approach to course evaluation. Assessment and Evaluation in Higher Education, $33(2), 191-202$.

Fox, A. (1974). Beyond contract: Work, power and trust relations. London: Faber and Faber.

Herriot, P. (1992). The career management challenge: Balancing individual and organisational needs. London: Sage.

Herriot, P., Manning, W. \& Kidd, J. (1997). The content of the psychological contract. British Journal of Management, 8(2), 151-162.

Jafri, M. H. (2012). Influence of psychological contract breach on organizational citizenship behavior and trust. Psychological Studies, 57(1), 29-36.

James, R. (2002). Responding to students expectations. OECD Publishing, France.

Koskina, A. (2013). What does the student psychological contract mean? Evidence from a UK business school. Studies in Higher Education, 38(7), 1020-1036.

Kember, D., Ho, A. \& Hong, C. (2008). The importance of establishing relevance in motivating student learning. Active Learning in Higher Education, 9(3), 249-263. Hentet 02/03/2015 fra https://doi.org/10.1177/1469787408095849

Morrison, E. W. \& Robinson, S. L. (1997). When employees feel betrayed: A model of how psychological contract violation develops. The Academy of Management Review, 22(1), 226-256. Hentet 20/04/2016 fra https://doi.org/10.2307/259230

Mykle, A. (1956). Sangen om den røde rubin. Oslo. Gyldendal Norsk Forlag.

Pekdemir, I., Koçolu, M. \& Gürkan, G. C. (2013). The effects of harmony of family, distributive justice, and role ambiguity on family member impediment: The mediating role of relationship conflict and an example of developing country Turkey. Asian Social Science, 9(9), 131-145. 
Pietersen, C. (2014). Negotiating a shared psychological contract with students. Mediterranean Journal of Social Sciences, 5(7), 25-33. Hentet 08/03/2015 fra https://doi.org/10.5901/mjss.2014.v5n7p25

Perlman, B. \& McCann, L. I. (1999). Student perspectives on the first day of class. Teaching of Psychology, 26(4), 277-279.

Potter, M., Gordon, S. \& Hamer, P. (2004). Nominal group technique: A useful consensus methodology in physioteraphy research. NZ Journal of Physioteraphy, 32(2), 70-75.

Ramsden, P. (2008). The future of higher education. Teaching and the student experience. Report. University of Glasgow.

Regan, J.-A. (2012). The role obligations of students and lecturers in higher education. Journal of Philosophy of Education, 46(1), 14-24. Hentet 03/06/2017 fra https://doi.org/10.1111/j.1467-9752.2011.00834.X

Robbins, S. P., Judge, T. A., Odendaal, A. \& Roodt, G. (2009). Organisational behaviour. Global and South African Perspectives. 2nd ed. Cape Town: Pearson Education Inc.

Rousseau, D. M. (1990). New hire perceptions of their own and their employer's obligations: A study of psychological contracts. Journal of Organizational Behavior, 11(5), 389-400. Hentet 14/11/2016 fra https://doi.org/10.1002/ job.4030110506

Rousseau, D. M. (1995). Psychological contracts in organizations. Understanding written and unwritten agreements. Newbury Park, CA: Cage.

Sander, P. Stevenson, K., King, M. \& Coates, D. (2000). University students' expectation of teaching. Studies in Higher Education, 25(3), 309-323.

Thomas, D. R. (2006). A general inductive approach for qualitative data analysis. American Journal of Evaluation, 27(2), 237-245. Hentet 14/11/2016 fra https://doi. org/10.1177/1098214005283748

Thorne, S. (2000). Data analysis in qualitative research. Evidence Based Nursing, 3(3), $68-70$.

Ullah, H. \& Wilson, M. A. (2007). Students' academic success and its association to student involvement with learning and relationships with faculty and peers. College Student Journal, 41(4), 1192-2012.

Yan, S. \& Zhu, Y. (2013). Impact of psychological contract violation on interpersonal trust during mergers and acquisitions. Social Behavior and Personality, 41(3), 487-496.

Wilkens, U. \& Nermerich, D. (2011). 'Love it, change it, or leave it' - understanding highly-skilled flexible workers' job satisfaction from a psychological contract perspective. The International Review of Management Studies, 22, 65-83. 


\title{
Veiledningssamtale for første års studenter: Et innspill til praksisnærhet og studiekvalitet
}

\author{
Anne-Lise With \\ Høgskolen i Innlandet
}

\begin{abstract}
This chapter deals with counselling for first-year students as a way to strengthen motivation and mastery. Based on the model ForVei - preparatory counselling, it is argued for the relevance of the counselling conversation as a part of follow-up and study programme quality in higher education and the time of mass education. ForVei is based on the basic values MSHRL - Met, Seen, Heard, Respected, Equal, which is central to the way the conversation is conducted. It is the student's motivation, mastery and well-being that are the main focus of ForVei, which is now practiced at several universities in Norway, such as the University of Oslo and Nord University. The chapter contains examples from our own research project on ForVei - counselling at INN University, where career guidance is a theme, as well. In the perspective of the student's motivation and experience, counselling and learning theory are used, among others, with Vance Peavy's constructivist SocioDynamic Counselling and Mark S. Savicka's concept of self-efficacy. The latter, for example, helps to shed light on differences in self-perception and belief in one's own resources and abilities. The chapter deals with these and other topics in light of study programme quality and ForVei - counselling for first-year students.
\end{abstract}

Keywords: study programme quality, follow-up, counselling conversation, MSHRL, transition, ForVei

\section{Introduksjon}

Kan man tenke seg veiledning som noe annet enn faglig veiledning og studieveiledning? Det kan være en veiledningssamtale om studielivet

Sitering av denne artikkelen: With, A.-L. (2020). Veiledningssamtale for første års studenter: Et innspill til praksisnærhet og studiekvalitet. I Y. T. Nordkvelle, L. Nyhus, A. Røisehagen og R. H. Røthe (Red.), Praksisnor undervisning - i praksis og teori (Kap. 4, s. 67-79). Oslo: Cappelen Damm Akademisk. https://doi. org/10.23865/noasp.94.ch4.

Lisens: CC BY 4.o. 
og studier, om valg som er gjort og skal gjøres, om utfordringer, planer, ønsker og jobbmuligheter. I dette kapitlet tematiseres studiekvalitet ut fra et veiledningsperspektiv basert på ForVei - forberedende veiledning. ForVei er et lavterskeltilbud som praktiseres ved flere institusjoner i UHsektoren, og kan betraktes som en type oppfølging av studenter. Sentralt i kapitlet er antagelsen om at veiledningssamtalen har potensial til å styrke studentens mestring av og motivasjon for studiene, og dermed studiekvaliteten.

\section{Overgang og mestring}

ForVei ble initiert ved NTNU i 2008 og eksisterte over mange år som et tilbud ved ulike sivilingeniørstudier. Etter hvert spredte det seg til andre høyskoler og universitet, som Universitetet i Oslo, Nord Universitet og Høgskolen i Vestfold. ForVei var og er i hovedsak rettet inn mot førsteårsstudenter, noe som har grunnlag i at frafallet blant førsteårsstudentene ved enkelte studier var alarmerende da pilotprosjektet startet opp. Like fullt ønsket ikke veilederne i ForVei at satsingen verken skulle være eller betegnes som «frafallsprosjekt». Det lå langt mer til grunn for ForVei enn institusjonens ønske om å holde på studentene. Intensjonen var helt fra starten av å fokusere på studentenes bevissthet rundt motivasjon og egne ressurser i en ny (for de fleste) livssituasjon. Overgangen fra videregående skole til høyere utdanning er en endringsfase, og mestring av studenttilværelsen og studiene kan være krevende og for noen svært vanskelig. Etter hvert var det fire ansatte i ForVei-teamet ved studentservice, før tilbudet opphørte i 2017, knappe ti år etter pilotprosjektets start. I startfasen var det et tilbud ikke bare til utvalgte fakultet ved NTNU sivilingeniørstudier, men også til pedagogikkstudenter. Det var dette miljøet som innstilte ForVei til en NOKUT-pris for studiekvalitet i 2010, en pris veiledningstilbudet også fikk. Paradoksalt nok opphørte tilbudet til pedagogikkstudentene etter et par år, av finansielle årsaker. Denne type veiledning er ressurskrevende og vil for mange fakulteter bli ansett som å være et ekstratilbud man ikke har råd til eller kan prioritere. Hva er og hvordan foregår ForVei? Det vil jeg etter hvert komme nærmere inn på, men aller først noen ord om aspekter ved studentmangfoldet på 200o-tallet. 
I Meld. St. 16 (Kunnskapsdepartementet, 2017) påpekes det at engasjement er en av de viktigste faktorene for at studentene skal lykkes. I masseutdanningens tid i dag er det å ta en bachelorgrad nærmest er å betrakte som obligatorisk, noe man «må ha». Det er ikke slik at motivasjon er selvsagt blant alle som starter på et studium, den kan også være av svært ulik karakter. Studentene er i masseutdanningens tid en mer heterogen gruppe enn noen gang, både med ulike forutsetninger for å mestre studiene og ulike beveggrunner for å begynne på et studium. «Studieatleten er statens student» og hører mer hjemme i den tiden da utdanning var mer privilegium enn plikt, sier Lidveig Bøe i Uniped. Tidligere hadde staten og studenten den samme rasjonaliteten, slik er det ikke i dag: «Ungdom i dag utøver mangsysleriet og rollemangfaldet, og dei dregst mot dei lange, flytande tidshorisontar» (Bøe, 2009, s. 65). Utdanningsbildet- og samfunnet er endret, og det er i dette landskapet av rollemangfold og endring vi skal manøvrere. Mange fagmiljøer har stilt seg spørsmål om hvordan engasjement og motivasjon i størst mulig grad kan skapes og opprettholdes. Ved hjelp av hva, og med hvilke metoder og virkemidler? Mer studentaktiv læring er innført i mange studieprogram, likeens flere seminarer, kreativ bruk av ny teknologi og mer praksis der hvor det er mulig. Samtidig vet vi at studiemiljø og læringsmiljø har betydning for trivsel og motivasjon. Feltet er med andre ord stort, og ikke minst er fagene og utdanningene forskjellige, også med henblikk på motivasjon. Det er likefullt et faktum at NOKUT sin landsdekkende undersøkelse, Studiebarometeret, over flere år har vist at det nasjonalt sett er svak score når det gjelder oppfølging og veiledning av studentene. 20-30 \% av dem som har deltatt i undersøkelsen, mener at de får for dårlig oppfølging. Når resultatene i undersøkelsene er blitt forelagt, henvises det gjerne til at nettopp tettere individuell oppfølging var en eksplisitt målsetting i kvalitetsreformen. Resultatet av undersøkelsene førte blant annet til at ledere av NSU, som Anders Langset 2015, begynte å jobbe målrettet for å innføre mentorordninger, ledet av lærere og erfarne studenter, som gruppetilbud til alle nye studenter gjennom det første studieåret. Dette er innført ved Universitetet i Bergen, og det er vedtatt at alle studenter ved Universitetet i Oslo skal ta del i en faglig mentorordning innen 2019 (Kunnskapsdepartementet, 
2017). Over flere år er det blitt tatt til orde for lavterskelordninger hvor studentene kunne få muligheter til å diskutere alt fra akademiske forventninger og studieteknikk til fremtidige yrkesmuligheter. De faglige mentorordningene vil sannsynligvis også bidra til å styrke studiekvaliteten med henblikk på faglig relatert oppfølging og veiledning ved de aktuelle institusjonene.

\section{Oppfølgingens mangfold}

Oppfølging kan også betraktes i et metaperspektiv, som en oppfølging som bidrar til at studentene lettere håndterer overganger og endringer i sin livssituasjon. Rent konkret kan det dreie seg om sosiale forhold, prokrastinering, stress, tvil rundt studievalg, jobbmuligheter og karriere. ForVei-tilbudet om én-til-én-samtale med studenter finner sted det første året nettopp med tanke på endringene det innebærer å starte og studere og erfaringene som er gjort. Veiledningen er basert på fem spørsmål, hvor mestring og motivasjon er overgripende temaer. Grunnverdiene i ForVei er MSHRL: Møtt, Sett, Hørt, Respektert, Likt. ForVei innebærer verdimessig sett at du som student er verdt oppmerksomhet, du er verdt å bli lyttet til, bruke tid på. Studentens historier, tanker og erfaringer tas på alvor og gis tid. Veileder lytter, spør og følger opp, av og til også med konfronterende spørsmål. Fem semistrukturerte spørsmål er utgangspunktet for samtalen, som spørsmålet: «Hvordan trives du som student?». I starten av veiledningstimen krysser studenten av på et skaleringsskjema fra 1-10, med spørsmålene om mestring og trivsel. Dette er ment å være utgangspunkt for samtalen, og veileder vender kanskje tilbake til det i løpet av samtalen. Ulike metoder og samtaleteknikker benyttes i samtalen, som motiverende intervju hvor målet er å fremkalle motivasjon og ansvarlighet i egen endring og utvikling, i tilfeller der dette er aktuelt. For alle studentene gjelder det at all oppmerksomhet er rettet mot han eller henne i en hel time. En tanke med ForVei er dessuten at veilederne skal ha tett kontakt med fagmiljø og studielederne både med henblikk på å informere om og markedsføre tilbudet. Det kan enkelte ganger være aktuelt å bruke studentenes erfaringer som kvalitetsstøtte til enkelte studier, 
som i tilfeller hvor det er faglige ting og problem som gjentas av flere på samme studie. Dette er i korte trekk ForVei og grunnidéene i denne type veiledning.

Om en mestrer overgangen og studielivet, kan bero på om en håndterer innleveringer av arbeidskrav, gruppearbeid, lesing, eksamenssituasjon og tidsplanlegging. I artikkelen «Servert på sølvfat» skiller Rønning, Johansen og Finbak mellom «ytre» og «indre» studiekvalitet (2010). Sistnevnte er vanskelig å operasjonalisere sier de, men sentralt her er studentenes eget arbeid med studiene, som tidsstyring og tidsbruk, som betingelser for å lykkes med studiene. I en ForVei-samtale vil dette kunne være et tema, hvor målet vil være å bidra til bedre håndtering og rutiner. Samtalen kan ta helt konkrete retninger, alt ut fra hva som kommer frem i veiledningssamtalen og hva studenten har behov for: «Sammen med en veileder med taushetsplikt snakker dere om det som er viktig for at du skal få mulighet til å oppleve økt motivasjon, mestringsfølelse, gjennomføringsevne og bedre trivsel» (Nord universitet, 2019). Der foregår ForVei i februar-mars, slik det gjorde ved NTNU, i tråd med ForVei-modellens tanke om at da har studentene gjort noen erfaringer med studenttilværelsen, rutiner, mestring og erfaringer med oppgaver, lesing og eksamen. For noen går alt på skinner, andre møter større utfordringer med både studier og det nye studentlivet. Et lavterskeltilbud som ForVei vil kunne fungere i en slik fase og sammenheng. I kapitlet «Veiledningens etiske forutsetninger» sier Dag Aasland: «Veiledning vil være viktig i sammenhenger der det av ulike grunner er behov for endring, utvikling, vekst eller modning» (2008, s. 219). Siden de fleste førsteårsstudentene er rundt 20 år, så er denne tiden også en modningsfase. Aasland mener for øvrig at en veiledningssamtale har likhetstrekk med det å undervise, siden søkelyset er på veisøkerens (her: studentens) læring og utvikling. I sosial læringsteori trekkes også gjerne utdanningsaspektet ved veiledning fram, blant annet med vektlegging på tidligere læringserfaringers betydning (Krumboltz, 2009). Dette har vist seg også å være aktuelt som element i en ForVei-kontekst, hvor veiledningssamtalen gjerne dreier inn på tidligere, ikke bare nåtidige, læringserfaringer. Bevisstheten om egne erfaringer kan bli en del av den «meningshelhet» som er et av temaene nedenunder. 


\section{Mening og mestring}

Et begrep som mestring kan forstås helt enkelt som det å «fikse» eller «klare», på skalaen fra det helt enkle til det mer kompliserte, og det kan favne både det praktiske og teoretiske. Men det kan også knyttes til mening og innstilling. Hans Inge Sævareid (2008) henviser til Aaron Antonovskys mestringsforståelse av menneskets evne til endring og utvikling, og finner det aktuelt i veiledningssammenheng. Et aspekt ved Antonovskys teori er at han knytter mestring til «opplevelse av sammenheng» og egenskaper som «begripelighet» og «meningshelhet». Mestringsevne forstås her langt på vei som en innstilling (Sævareid, 2008, s. 45-46). Trekker vi dette inn i en studiekontekst, kan veiledningssamtalen betraktes som et bidrag til at studenten blir (mer) bevisst sin innstilling til studiet, til det å studere og til valg av studium. Det er også i et slikt perspektiv vi kan se ForVei-samtalen som meningsskapende. En dimensjon ved meningshelhet kan være spørsmål rundt studievalg eller karrierevalg fremover. Man kan tenke seg at dette er spesielt relevant for studenter på disiplinfag som pedagogikk, mediefag, litteraturvitenskap, sosiologi og internasjonale studier, det vil primært si humaniora og samfunnsfag. Tone Gaarder og Ingjerd Gravås (2011), med bakgrunn og erfaring fra Karrieresenteret ved Universitetet i Oslo, påpeker at studierelaterte spørsmål fort kan bevege seg inn i karriereveiledning, her forstått som temaer relatert til arbeidsliv og jobb. Slik kan man si at ForVei-veiledningen, ut fra de behov og spørsmål som måtte dukke opp, kan fremme karrierekompetanse eller karrierelæring. Det er neppe kun min erfaring at studentenes motivasjon kan ha sammenheng med det de tror, tenker, vet og ikke vet om arbeidsliv og muligheter. I et eget forskningsprosjekt ved Høgskolen i Innlandet (HINN) om ForVei (With, 2019) viste det seg at karriererelaterte spørsmål var noe mange studenter ønsket å samtale om. Det spente fra konkrete spørsmål som jeg besvarte etter beste evne eller henviste videre, til de som ønsket å lufte tanker om karriereønsker eller tvil om studie med henblikk på ønsket karriere. Prosjektet involverte til sammen 19 studenter ved to bachelor-disiplinstudier.

Det er viktig å spørre om en veiledning som ForVei kan sees på som en type praksisnær undervisning eller sees i sammenheng med slik undervisning? Da må vi kunne tenke oss at skillet mellom undervisning og 
veiledning til en viss grad opphører, og velge å se ForVei som en undervisningsform, slik oppgaveveiledning er en annen faglig undervisningsform enn forelesningen. ForVei er i stedet en erfaringsbasert og -rettet veiledning på studentenes premisser.

Et aspekt ved høyere utdanning er at utfordringene er større for noen studenter enn andre. Graden av så vel teoretisk fortrolighet som tro på egen mestring er som vi vet ulikt fordelt. Studentmassen er heterogen, også når det gjelder sosiale forskjeller og «kulturell kapital» slik Pierre Bourdieu har introdusert begrepet (Bourdieu, 1995). Det forbindes primært med kompetanse på kultur- og kunstområdet, men utdanningskapital er også en kulturell kapital, den attesterte formen for kulturell kapital, ifølge Bourdieu. Og det er her aktualiteten av et bourdieusk perspektiv kommer inn. I likhet med andre mennesker er også studenter produkt av livsvilkår som i stor grad formes av familiebakgrunn, skole og miljø, og dermed tenker og handler ut fra dels ulik logikk. Med Bourdieu er dette vår «habitus», det vil si tillærte tanke- og adferdsmønstre, ulik logikk og tankegang, som er de produkt av livsvilkår som i stor grad formes av familiebakgrunn, skole og miljø. Habitus er relativt, noe som kommer til syne sammenlignet med noe annet og noen andre. Målet for samtlige studenter kan sies å være utdanningskapital og selve «attesten». Motivasjonen for og veien til den vil imidlertid gjerne ha en tendens til å avspeile seg i ulike typer habitus. Dette fører oss over på neste, men et ofte tilhørende, tema: selvoppfattelsen.

Ifølge Savickas' teori om karrierekonstruksjon så har individet flere forskjellige selvoppfattelser, man kan for eksempel se seg selv som «kompetent» $\mathrm{i}$ en av livsrollene man tar del i, mens man kan ha andre selvoppfattelser i en annen rolle. Oppfattelsene danner «personens system af selvopfattelser». Det å «tro på egne evner» er, sammen med «selvværd», for Savickas eksempler på en metadimensjon i selvoppfattelsen. Denne troen på egne evner bidrar til å forme «individets rolle- og opgavespecifikke selvopfattelse» (Savickas i Højdal \& Poulsen, 2009, s. 226). Og selv om dette er teori om valgprosesser og karriere, er tanken om selvoppfattelse ikke irrelevant å anvende i et utdanningsperspektiv, ei heller i et bourdieusk og sosiologisk perspektiv. Savickas betegner det sosiale nettverket som individet inngår i, som «det kulturelle manuskript» (s. 227). 
Det sosiale nettverket som individet inngår i, synes å ligge tett opp til habitus. Dessuten kan nok dette også ha relevans for både utdanningsvalg og mestring av studiesituasjonen. Både Savickas og John Krumboltz refererer til Banduras begrep Self-Efficacy, som defineres slik: «(...) individets tro på egne evner til at organisere og igangsætte handlinger, der er nødvendige for at opnå noget bestemt» (Højdal \& Poulsen, 2009, s. 103). Hva mennesket tror om seg selv og om miljøet rundt seg, former forventningene til utbytte eller resultat. Self-Efficacy påvirker både hvor mye vi anstrenger oss for å nå våre mål, og hvor lenge vi holder ut når vi møter motstand. Det eksisterer rett og slett forskjeller, både i en mer løsrevet individuell forstand og i et sosiologisk perspektiv. I lys av slike perspektiv kan ForVei betraktes som en veiledningssamtale med muligheter til å bidra til bedre selvoppfattelse, større klarhet og stimulere til endring i holdning og handling hos dem det er aktuelt for. Dette synes beslektet med Ronald Barnetts vektlegging av studentens opplevde og praktiserte liv - og at studentens væren i verden må være det sentrale sammen med det å vinne selvsikkerhet og gjennom motstand utvikle tålmodighet og mot (Barnett, 2000).

\section{Mer bevisst og bedre innsikt}

ForVei er et ressurskrevende tilbud, og spørsmål flere vil stille seg, er hvordan og hvorvidt vi kan vite om veiledningssamtaler som ForVei har innvirkning på motivasjon, mestring, trivsel og frafall. De årlige tilbakemeldingene i rapportene 2009-2016 fra NTNU tyder på at slike veiledningssamtaler kan ha en slik innvirkning, men dette er vanskelig å måle statistisk sett. Det vanlige var at ForVei ved NTNU fikk tilbakemeldinger fra om lag halvparten av studentene som hadde vært til veiledning, via skjemaer som ble sendt ut tre uker etter at veiledningen hadde funnet sted, og med frivillig respons. Også halvparten av mine informanter i forskningsprosjektet om ForVei ga anonymisert tilbakemelding, og det var her samme spørsmål som ved NTNU (With, 2019). Målet med tilbakemeldingen var tilgang på informasjon om hvordan studentene opplevde veiledningssamtalen. Hva hadde de fått ut av denne timen, eller hva trodde de at de hadde fått ut av den? Hvordan ble dette i så fall uttrykt, 
med hvilke ord? Studentenes tilbakemeldinger var relativt korte, og nedenunder er noen av dem sitert og parafrasert etter spørsmålene, dernest kommentert. Sitatene er valgt ut som representative eksempler på hvilke type tilbakemeldinger som kom.

På spørsmålet «Har veiledningen endret ditt syn på studiet?» var ett av svarene følgende: «Jeg har fått et bedre syn på studiet fordi etter samtalen med veilederen følte jeg at etter studiet har jeg flere åpne dører hvor jeg kan velge forskjellige yrker». På samme spørsmål svarte en annen: «(...) det eneste måtte være at jeg er mer bevisst på å sikte studiet dit jeg ønsker selv». Svaret indikerer at veiledningssamtalen har fungert godt med henblikk på karriereveiledning, og viser også at studenten opplever veiledningen som motiverende. En annen student skriver: «Veiledningen har gjort mye for tankene og planleggingen rundt videre studier». Dette henspeiler på at veiledningssamtalen har bidratt til å åpne opp for noen muligheter og tanker som studenten ikke har sett før. En student skriver at hun var blitt mer bevisst sin tidsbruk. I dette tilfellet, som hos flere andre, hadde veiledningen dreiet inn på prokrastinering og mangel på gode rutiner. Dette har ført til større bevissthet om tidsbruk og rutiner, slik jeg forstår det, og forhåpentligvis også handling. Den samme studenten er fornøyd med at veiledningen også var personlig, ikke bare faglig. Dette er også blitt høyt verdsatt hos NTNU-studentene opp gjennom årene, det framgår i tilbakemeldinger publisert i deres rapporter. Det personlige kan romme mye forskjellig, fra helseplager og bosituasjon til tvil og tilfredshet. På spørsmålet «Har veiledningen gjort noe med din studiesituasjon?» er ett svar: «Ja, jeg ser nå bacheloren som et mulig studie å fortsette med». Det kan virke som om studenten har opplevd at veiledningen har fungert som døråpner til flere retninger som studiet kan lede til. På spørsmålet «Hvor fornøyd er du med veiledningen du fikk?» svarte nesten alle at de var «veldig fornøyd» eller «ganske fornøyd». Flere av studentene supplerte med at de var blitt «mer bevisst». Noen konkretiserte hva de var fornøyd med, som det å kunne sette seg ned og snakke om «studier og skolen».

I mange ForVei-rapporter fra NTNU har langt over halvparten av de som ga tilbakemelding på spørsmålet «Hva var viktigst i ForVei-veiledningen?», svart at det viktigste var å tenke høyt om sin egen situasjon, 
dernest det å bli lyttet til samt å få innspill og råd fra veileder. Dette indikerer verdsetting av denne type veiledning. I ForVei er det som nevnt studenten som er i fokus med grunnlag i kjerneverdiene MSHRL. Det har igjen å gjøre med en åpen og aksepterende sansning fra veileders side, $\mathrm{i}$ retning av det Jette Fog påpeker (Fog, 1995). Det er vanskelig å sette sansningen foran begrepene, sier hun, for det krever en «aflæring af den utidige begrepsdannelse, den utidige klassificering» (Fog, 1995, s. 85). Man skal heller ikke tro at man vet før man faktisk gjør det, sier hun. Det er vår forutforståelse som bør vike. Dernest må vi sikre oss at vi faktisk har forstått det vi har hørt; suspendere vår egen forståelse. Det kan være ved å spørre: «Har jeg forstått deg rett at det er slik at (...)» (Fog, 1995, s. 85). På denne måten kan det skapes rom for at noe bekreftes, noe endres, noe blir bedre, noe blir nytt, på en måte som synes å være i tråd med MSHRL- verdiene. Verdiene kan høres enkle ut, for noen kanskje banale, men skal praktiseres i møte med studentene. Det er i veiledningssamtalene det gjelder, det er her verdiene, metoden og veileders personlige egnethet kommer til uttrykk. ForVei er ment å romme livet som student i mange fasetter, alt ut fra behov. Dette nedfeller seg i Nord universitetet sin informasjon hvor det står: «ForVei passer for alle studenter, enten du lever studentlivets glade dager, eller tilbringer hele døgnet på lesesalen. Uansett akademiske prestasjoner, sosialt nettverk og engasjement tilbyr vi våre individuelle veiledningssamtaler til deg» (Nord universitet, 2019). I mitt eget forskningsprosjekt var da også det brede spekteret av type studenter og mangfoldet av temaer vi var innom, slående. Mens noen kun ønsket å samtale om jobbmuligheter og fagkombinasjoner, var andre mest opptatt av å fortelle hvordan de mestret studiehverdagen sin med en diagnose eller syndrom, mens andre igjen hadde behov for å lufte sine tanker og tvil om valg av studie og få respons på dette. I enkelte tilfeller ble det aktuelt med endringssnakk for å bedre dårlige mønstre og mangel på gode rutiner. I ett tilfelle ble det aktuelt å informere og råde studenten til å ta kontakt med helsetjenesten. Med andre studenter var det usikkerhet rundt valg av videre utdanning som ble hovedfokus.

De empiriske dataene fra ForVei-prosjektet totalt sett, med det som framkom i samtalene, men også i tilbakemeldingene, har jeg tolket som at ForVei nettopp er mulighet for å bli mer bevisst og motivert. De 19 
samtalene viste også et stort spenn innen motivasjon, mestring og tvil, de viste også hvor ulike behovene er med henblikk på temaer som ble tatt opp (With, 2019). Ikke minst har veiledningsprosjektet gitt meg som fagperson et bedre innblikk i studenters erfaringer og ulike behov for støtte som eksisterer innenfor rammen studieliv og «rollen» som student.

\section{En helt annen arena}

ForVei er ment å være en egen arena på studiestedet. Veileder skal ikke være studentens faglærer på det aktuelle studiet. Dette skal holdes adskilt, rollene skal ikke blandes, noe ForVei-veilederne Ilan Dehli Villanger og Håvard Engen har understreket (intervjuer 2012). Det er like fullt viktig at den som veileder kjenner til regler, rammer og krav på et institusjonelt nivå. Uansett er det studentens behov for å ta opp ting som skal stå sentralt, det være seg tidsfrister, skriving, leseteknikker, faget og gruppearbeid. Samtidig skal studentene også utfordres der det kan være aktuelt. På den måten fungerer skaleringsskjemaet fint både som utgangspunkt for selve veiledningen og noe å komme tilbake til i en oppsummering.

Et annet aspekt ved ForVei-metodikken er vektleggingen av å skape en god setting. Det innebærer å sitte i omlag samme høyde, hvordan man er plassert i rommet og gjerne servering av en kopp kaffe eller te. I en undersøkelse av veiledningstilbudet ved NTNU (Rønning \& Landrø, 2015) er 17 studenter blitt intervjuet om studieveiledning. Flere hadde opplevd ForVei som positivt forskjellig fra den øvrige studieveiledningen. De sier det er noe annet enn besøk hos studieveileder, som de har erfart gjerne sitter ved en PC og lett gir dem følelsen av å bli forstyrret. De mente også at ForVei-veilederne hadde en annen eller ekstra kompetanse, og viste mer «hjertevarme» enn de andre studieveilederne. De som har foretatt undersøkelsen velger å forstå dette som uttrykk for en mer personorientert enn saksorientert tilnærming (Rønning \& Landrø, 2015, s. 105). Det personorienterte er da også i tråd med grunnverdiene i ForVei, og ForVei kan på sin side sees i sammenheng med Peavys veiledningsteori og betegnelsen SocioDynamisk samtale. Peavy sier at den sosiodynamiske samtalen er skapt til å: «(...) bruge beskrivelser av meninger og erfaringer som den primære kilde til motivation» (Peavy, 2005, s. 13). Han tar til orde for et 
perspektiv hvor mennesket kan oppfattes som en «historieforteller» det narrative selv - og som «meningsskaper» i samkonstruksjon (Peavy, 2005, s. 18). Å se erfaringen som kilde til motivasjon er interessant av flere grunner. En av dem er deltagelsen eller medvirkningen når man forteller om og får anledning til å reflektere over egne erfaringer med studiet og studietilværelsen. En veiledningssamtale med grunnlag i ForVei-verdiene og -metoden kan sånn sett utgjøre grobunn for økt selvrefleksjon og motivasjon hos studenten tidlig i studiet.

Peavy (2005) mener for øvrig at en god veiledningssamtale er mer en fortelling om relevante historier enn det er et intervju. Et viktig prinsipp i SocioDynamisk samtale er ikke minst: «(...) at vejlederen skal værdsette den vejledningssøgendes beskrivelse af erfaringer og hvad mening denne erfaring giver den vejledningssøgende» (Peavy, 2005, s. 100). Min erfaring fra ForVei-veiledningen med studentene i prosjektet samsvarer med dette aspektet. Vi kunne sammen se sammenhenger og bringe samtalen videre inn på et som regel fruktbart og kanskje klargjørende spor.

For å oppsummere så blir det praksisnære å forstå som det erfaringsbaserte og dialogiske i en veiledningssamtale. Det er studentens væren i (student)verdenen som er i fokus. Praksisnær undervisning blir i lys av dette en mulighet til å utvide og se den «andre arenaen» som tilhørende undervisning i bred forstand.

\section{Litteratur}

Barnett, R. (2000). Realizing the university in an age of supercomplexity. Buckingham: Society for Research into Higher Education \& Open University Press.

Bourdieu, P. ([1979] 1995). Distinksjonen. Oslo: Pax Forlag A/S.

Bøe, L. (2009). Studentar: I statens fald eller i eit livsmangfald? Uniped, 32(3), 55-67.

Fog, J. (1995). Samtalen som redskab II. I J.Fog, Med samtalen som udgangspunkt.

Det kvalitative forskningsinterview, (s. 78-94). København: Akademisk Forlag.

Gaarder, T. \& Gravaas, I. (Red.).(2011). Karriereveiledning. Oslo: Universitetsforlaget.

Haug, H. E. (2017). Karrierekompetanser, karriereloering og karriereundervisning.

Bergen: Fagbokforlaget.

Højdal, L. \& Poulsen, L. (2009). Karrierevalg. Teorier om valg og valgprocesser.

Danmark: Studie og Erhverv a.s. 
Krumboltz, J. D. (2009). The happenstance learning theory. Journal of Career Assessment, 17(2), 135-154. https://doi.org/10.1177/1069072708328861

Kunnskapsdepartementet. (2017). Kultur for kvalitet i høyere utdanning. (Meld St. 16 (2016-2017). Hentet fra https://www.regjeringen.no/no/dokumenter/ meld.-st.-16-20162017/id2536007/

Nord universitet. (2019). www.nord.no/forvei. 19.03.2019.

Peavy, V. R. (2005). At skabe mening - den sociodynamiske samtale. Danmark: Studie og Erhverv a.s.

Rønning M., Johansen, K. \& Finbak, L. (2010). Servert på sølvfat? Studiekvalitet i høyere utdanning - slik studenter ser det. Uniped, 33(2), 50-59.

Rønning, W. M. \& Landrø, K. (2015). Studieveiledningstilbudet til NTNUstudenter: status og utfordringer. Trondheim: Institutt for voksnes læring og rådgivningsvitenskap, NTNU.

Sævareid, H. I. (2008). Om 'menneskearbeid' og 'ekspertarbeid'. I B. S. Eide, H. H. Grelland, A. Kristiansen, H. I. Sævareid \& D. Aasland (2008). Til den andres beste - en bok om veiledningens etikk. Oslo: Gyldendal Norsk Forlag AS.

With, A. L. (2019). Studentforberedende veiledning: et spørsmål om motivasjon, mestring og studiekvalitet. Skriftserien -1: Elverum/Lillehammer: HINN.

Aasland G. D. (2008). Veiledningens etiske forutsetninger. I B. S. Eide, H. H. Grelland, A. Kristiansen, H. I. Sævareid \& D. Aasland (2008). Til den andres beste - en bok om veiledningens etikk (s. 11-23). Oslo: Gyldendal Norsk Forlag AS.

\section{Intervjuer}

Ilan Dehli Villanger 12.01. $2012 \mathrm{UiO}$

Håvard Engen 19.11. 2012 NTNU 



\title{
KAPITTEL 5
}

\section{Seminar som undervisningsform ihøgere utdanning}

\author{
Anne Røisehagen \\ Høgskolen i Innlandet
}

\begin{abstract}
Seminar is a form of teaching that is widely used in universities and university colleges in Norway. The article asks three questions about the seminar as a form of teaching: what is a seminar, how can seminars be used, and why should seminars be used as a teaching method in higher education. The article's empirical data is taken from a case study conducted by the author, and revolves seminars as a learning arena in higher education. The chapter refers to a concrete programme and the conduction of a seminar in order to shed light on the importance of student-active learning forms. In addition, references are made to statements from both vocational teachers and students who have participated in the research study. Through analysis of empirical findings and concrete examples, theory is mainly derived from collaborative learning, situated learning and the importance of reflection for learning. One of the main findings is that seminars must be well planned, there must be high commitment on the vocational teachers' part, and there must be a clear connection between themes in lectures and seminars. The students experience that they gain an understanding of the connection between theory and practice by having a lecture on one day, and a seminar built on the same theme two days later. The students also express through evaluation that they experience the seminars as educational, engaging, challenging and motivating.
\end{abstract}

Keywords: seminar, student-active teaching method, understanding of the connection between theory and practice

\section{Introduksjon}

Seminar er et begrep og en undervisningsform som kommer igjen i mange studie- og emneplaner i UH-sektoren i Norge. En beskrivelse av begrepet seminar kan være:

Sitering av denne artikkelen: Røisehagen, A. (2020). Seminar som undervisningsform i høgere utdanning. I Y. T. Nordkvelle, L. Nyhus, A. Røisehagen og R. H. Røthe (Red.), Praksisncer undervisning - i praksis og teori (Kap. 5, s. 81-97). Oslo: Cappelen Damm Akademisk. https://doi.org/10.23865/noasp.94.ch5.

Lisens: CC BY 4.o. 
Seminar er en form for akademisk undervisning, enten ved en akademisk institusjon eller tilbudt av en kommersiell eller yrkesorganisasjon. Seminaret har funksjon av å bringe sammen små grupper for regelmessige møter, med fokus hver gang på noen bestemte emner, hvor alle tilstede er bedt om å delta aktivt.

Det er i hovedsak et sted hvor tildelte temaer diskuteres, spørsmål kan rettes og debatter kan gjennomføres. (Bø \& Helle, 2008, s. 275)

Spørsmål jeg vil forsøke å svare på i dette kapitlet er: Hva er seminar? Hvordan kan seminar brukes som undervisningsform? Og hvorfor bør seminar benyttes som undervisningsform i høgere utdanning? Jeg vil argumentere for at seminar er en undervisningsmetode med mulighet for stor variasjon og studentaktivitet. Seminar er en undervisningsform hvor studentene kan utvikle sine kunnskaper, ferdigheter og generelle kunnskaper i faget. Det er allikevel viktig å bemerke at studentaktive undervisningsformer ikke nødvendigvis er synonymt med (det samme som) praksisnær undervisning. Koblingen mellom det studentaktive og det praksisnære blir derfor et viktig fokus. Jeg vil forsøke å vise i kapitlet at seminar som undervisningsform er en arena hvor studentene har en bedre mulighet til å koble teori og praksis. For å gi svar på spørsmålene ovenfor vil jeg i kapitlet vise eksempler fra eget forskningsprosjekt «Seminar som læringsarena i høgere utdanning». Empirien ble samlet inn våren 2017. Dette er beskrevet i avsnittet «Kort beskrivelse av fagområde og forskningsprosjekt» nedenfor.

Jeg er ansatt som høgskolelektor ved Høgskolen i Innlandet, Institutt for pedagogikk, med studiested Lillehammer. Min utdanningsbakgrunn er sykepleier og pedagog, og jeg underviser på bachelor-programmet (BA) i pedagogikk. Jeg er emneansvarlig for vårsemesteret 2. studieår i emnet rådgivning og veiledning i pedagogiske virksomheter 1 og 2, både på fulltids- og deltidsstudiene. Jeg er i tillegg faglærer både på 1. og 3 . året i BA- programmet. Jeg har stor interesse for studentaktiviserende undervisningsformer, og mener det er av faglig pedagogisk og didaktisk interesse at forskning og formidling gjøres slik at studentene aktiviseres på ulike måter. Hvis vi skal få til en endring fra å undervise kun i store forelesningssaler til mer studentaktive undervisningsformer, er det viktig at denne forskningen blir tilgjengelig for alle universitets- og høgskoleansatte. 
I stortingsmelding Kultur for kvalitet i høgere utdanning står det:

Universitet og høgskoler må kontinuerlig moderniseres og tilpasses krav og forventninger fra samfunnet som stadig utvikler seg. Gjennom å utdanne kandidater med høy kompetanse spiller universitet og høgskoler en avgjørende rolle i samfunnet. I et arbeidsmarked som i stadig større grad preges av et høyere kompetansenivå og mindre rutinearbeid, er det behov for fagfolk som kan utøve etisk refleksjon, kreativ problemløsning og kritisk tenkning, og som kan håndtere kompleks og tvetydig informasjon samt samarbeide på tvers av geografiske, faglige og kulturelle grenser. (Kunnskapsdepartementet, 2017, s. 12-14)

I stortingsmeldingen blir dette omtalt som generiske ferdigheter (figur 1.1). Det blir pekt på at disse ferdighetene er i godt samsvar med universitetenes klassiske dannelsesidealer. Utdanning må legge vekt på læring som utvikler slike ferdigheter. Målet med utdanning er å gjøre studentene bedre rustet til å møte et samfunns- og arbeidsliv som krever kontinuerlig omstilling.

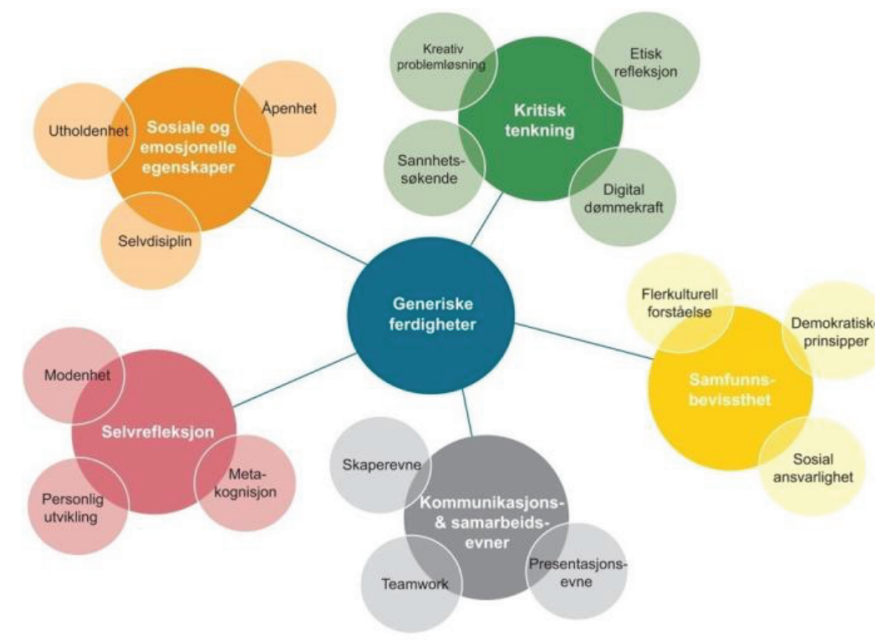

Figur 1.1 Generiske ferdigheter (Kunnskapsdepartementet, 2017. s. 14).

I kapitlet vil jeg utdype hvorfor samarbeid vil styrke utvikling av de generiske ferdighetene, i tillegg til den fagspesifikke kompetansen. Det vil si at i tillegg til å få en kompetanse i et bestemt fag eller profesjon får studenten også ferdigheter de vil få nytte av som deltakere i samfunnet. 


\section{Kort beskrivelse av fagområde og forskningsprosjekt}

Veiledning og rådgivning er områder som har ekspandert som fagfelt de siste årene. Innenfor utdanningssektoren og helse- og sosialfaglig arbeid ser vi at både veiledning og rådgivning får mye oppmerksomhet. Det er store variasjoner i hvordan begrepene rådgivning og veiledning defineres, og hvordan begrepene forstås, avhenger av hvilket fagfelt og hvilken sammenheng vi ser det fra. Rådgivning og veiledning kan med en fellesnevner beskrives som kunsten i å bistå mennesker i utvikling og i valgsituasjoner. I vår sammenheng fokuserer vi på det rådgivnings- og veiledningsfeltet som retter seg mot pedagogiske virksomheter som for eksempel skole, SFO, barnehage, fritidsklubber og voksenopplæring. Det er primært innenfor dette fagfeltet vi henter teoretiske, metodiske og praksisbaserte perspektiv på rådgivning og veiledning. Rådgivning og veiledning i pedagogiske virksomheter 1 tar opp utfordringer og muligheter knyttet til veiledning på individ-, gruppe- og organisasjonsnivå (PED 1006/1 inn.no emnebeskrivelse).

Veiledningspedagogikk er et vidt felt hvor vi betrakter veiledning som en pedagogisk aktivitet der vi arbeider med kommunikasjon, forandringsarbeid, kompetanseutvikling, personlig utvikling og konflikthåndtering. I emnet skal vi gi en innføring i noen av de viktigste tradisjonene og de mest sentrale teoriene innenfor veiledningspedagogikk og pedagogisk rådgivning. Det legges vekt på å skape undervisningssituasjoner der studentene kan dele opplevelser og erfaringer samt reflektere sammen rundt ulike veiledningsprosesser. Kommunikasjon, samspill og tverrfaglig samarbeid er sentrale begrep (PED 1006/1 inn.no emnebeskrivelse).

Mitt forskningsprosjekt bygger på case som metode. Casestudie kan beskrives som intensive kvalitative studier av en eller noen få undersøkelsesenheter. Undersøkelsen ses på som et komplekst hele, der mange underenheter og deres forhold til hverandre beskrives i detalj (Andersen, 2013 s. 14). Andersen (2013) skriver at det sentrale er at en hendelse ses i lys av en analytisk kontekst som knytter sammen observasjoner, tolkninger og analyse. I gjennomføringen av casestudiet «Seminar som læringsarena i høgere utdanning» er det samlet inn mange underenheter for å kunne se 
på kompleksiteten av seminaret som læringsarena. Empiri til forskningsstudiet er samlet inn gjennom to ulike spørreskjema, ett spørreskjema hvor studentene svarer anonymt, og et annet spørreskjema hvor studentene tilkjennegir seg med navn. Studentenes emneevaluering er også tatt med i empirien. Det er i tillegg samlet inn to refleksjonsnotater fra hver student etter gjennomførte seminarer. Ut fra refleksjonsnotatene ble det foretatt et tilfeldig utvalg av 15 studenters refleksjonsnotater som ble analysert med utgangspunkt i Blooms taksonomi. I emnet blir fremmøte og fravær på hver student registrert både på forelesning og på seminar. I tillegg har jeg hatt tilgang til studentenes eksamensresultater. Mangfoldet av innsamlet empiri er med på å sikre validitet og kvalitet i forhold til case som forskningsmetode. Det er innhentet nødvendige samtykker fra studentene i henhold til forskningsetiske retningslinjer. Lærere som har deltatt i emnet, har skrevet ned sine tanker i form av refleksjonsnotat med noen veiledende fokusområder. Faglærerne har ikke deltatt som medforskere. Deres innspill blir sett på som en underenhet av og blir viktig for å se på forskningsprosjektet som et komplekst hele. Det er et stort omfang av innsamlet empiri, som er kategorisert og bidrar til analyse i forskningsprosjektet om seminar som læringsarena i høgere utdanning. Den endelige forskningsrapporten forventes å være ferdig på nyåret 2020 . I dette bokkapitlet tar jeg med noen eksempler fra ulike empiriske funn og mine egne erfaringer som faglærer.

Beskrivelse av case: Emnet rådgivning og veiledning i pedagogiske virksomheter 1 (RoV1) er et emne i 4. semesteret i BA-pedagogikk. Emnet kan også inngå som valgemne for andre studenter ved høgskolen, som for eksempel organisasjon og ledelse, i tillegg til at noen studenter tar emnet som videreutdanning eller etterutdanning. Våren 2017 var det totalt 88 studenter som møtte ved studiestart og 86 studenter som fullførte eksamen. På emnet er det 75 \% oppmøteplikt, og vi fører fraværslister. Studentene har til sammen åtte forelesningsdager à fire timer og sju seminarer à tre timer. Emnet har en varighet på ti uker. Det er fire arbeidskrav i emnet. Det er en fagoppgave som gjennomføres i grupper på 4-5 studenter, en individuell fagoppgave og to refleksjonsnotater fra deltagelse på to ulike seminarer. Studentene velger selv hvilke to seminarer de skriver refleksjonsnotat fra. Eksamen er en 6 timers 
skoleeksamen. På seminarene er studentene delt opp i faste klasser på til sammen 30 studenter. Innad i seminarklassene blir studentene igjen delt opp i mindre grupper avhengig av tema og aktivitet på seminaret. Det er tre faglærere knyttet til emnet, og hver faglærer følger de samme studentene på seminarene gjennom hele perioden og gir tilbakemelding på arbeidskrav til de samme studentene. Tema på forelesningen undervisningsdagen blir fulgt opp på førstkommende seminar. På seminaret er det lagt opp til studentaktivitet. Det kan være aktiviteter som for eksempel er casebasert, praktiske øvelser, gruppearbeid, framlegg eller refleksjonsøvelser.

\section{Hva er seminar?}

Seminar som undervisningsform har røtter langt tilbake i tid, og utviklet seg som en del av pietismens pedagogikk på 1700 tallet (Nordkvelle, 2003). At læring foregår i mindre grupper der studenter leser, argumenterer og skriver for hverandre med kyndig veiledning, er en minst 250 år gammel praksis i det tyske seminaret. Ved universitetet ble seminarene fora for drøfting og litteraturanalyser der studentene var aktive med innlegg som førte til diskusjoner og der lærerne kunne opptre som veiledere og ordstyrere (Nordkvelle, 2011). Dialogen som undervisende konversasjon er av gammel dato og kan dateres tilbake til Protagoras (485-410 f.Kr.). Andre fremhever Sokrates som kilde og inspirator. Seminarbetegnelsen er av nyere dato. Seminar betyr egentlig «planteskole», og i undervisningssammenheng er begrepet knyttet til lærerseminarene. Dette ble opprettet av August Herman Francke (1664-1727) ved universitetet i Halle tidlig på 1700 tallet. Dette var undervisning hvor Francke daglig holdt to timer lange diskusjoner med sine studenter for å kvalifisere dem til sin lærerutdanning (Pettersen, 2005).

De første moderne universitetene, hvor seminarformen vokste frem som konkurrent til den tradisjonelle forelesningsformen, var Universitetet i Halle og senere Universitetet i Göttingen (1737). Læringsoppgaver for studentene var tekstkritisk lesing, diskusjon og muntlig forsvar. Senere fikk skriving en mer sentral plass. Det ble argumentert for at det å lese, lytte, notere og diskutere muntlig ikke var tilstrekkelig for 
intellektuell utvikling. Det krever i tillegg at studentene får trening i å formulere og uttrykke seg skriftlig (Pettersen, 2005). Seminartradisjonen ved tyske universiteter ble videreført til USA. I 1876 etablerte H. B. Baxter seminar som undervisningsform ved Johns Hopkins-universitetet i Baltimore. På slutten av 1700-tallet og tidlig 1800-tallet ved Universitetet i Glasgow finnes en lignende løsrivelse fra den tradisjonelle akademiske praksis. George Jardine kom med en radikal endring i synet på undervisning. Han fremhevet at lærere måtte se på seg selv som hjelpere i studentenes læreprosesser. Det å legge til rette for samarbeid mellom studentene og få studentene til å artikulere sine synspunkter og faglige posisjoner mente Jardine var lærernes fremste oppgave (Pettersen, 2005). Jardine påpekte videre at for at studentene skulle utvikle sin tenkning, måtte studentene viderekommunisere dette muntlig så vel som skriftlig. I Jardines undervisningsopplegg måtte studentene derfor levere inn skriftlige arbeider jevnlig og få rask og hyppig tilbakemelding på sine arbeider fra læreren.

Det er lange tradisjoner i norsk høgere utdanning for seminarundervisning og kollokviegrupper. Lærere ble utdannet ved «Seminar» - først opprettet som Trondenes Seminarium i 1824, og skoleslaget ble omdøpt til «Lærerskole» i 1902. «Det praktisk teologiske seminar» ble opprettet i 1848. «Pedagogisk seminar» ble etablert i 1907 som et påbygningsstudium for universitetsutdannede kandidater som ønsket å arbeide i skolen. Seminarene har hatt betydning som et sted der man lærer gjennom praktiske øvinger og en mer helhetlig og yrkesforberedende arbeidsform. Innenfor UH-sektoren i nyere tid er seminarene beskrevet som en undervisningsform der studentene får trening i å presentere egne tolkninger av litteraturen og diskutere disse med medstudenter og undervisere. I sluttrapporten av «Evaluering av Kvalitetsreformen» pekes det på at det er varierende hvor godt seminarundervisning og kollokviegrupper fungerer (Michelsen \& Aamodt, 2007). I faglitteraturen kan det være vanskelig å skille klart mellom det klassiske seminaret og seminarene som gruppeundervisning. Hvilke kriterier som kjennetegner et godt seminar, blir derfor vanskelig å identifisere i faglitteraturen.

Seminar er et begrep som kommer igjen i de fleste studie- og emneplaner i høyere utdanning i Norge. Når det gjelder undervisningsmetoder i 
studie- og emneplaner, ser en at det legges opp til varierte læringsaktiviteter for studenter. Eksemplet under er hentet fra emneplanen som er med i casestudiet «Seminar som læringsarena i høgere utdanning».

Undervisnings- og læringsmetoder: Emnet vil legge opp til en veksling mellom forelesninger, seminarer, praktiske øvelser, oppgaveløsning og varierte arbeidskrav (PED 1006/1 inn.no emnebeskrivelse).

Seminar er oppført som undervisningsmetode uten at det står beskrevet hva det konkret legges i aktiviteten. I emneplaner kommer ofte begreper som seminar og gruppearbeid. Roar Pettersen (2005) benytter gruppeundervisning hvor en kan kjenne igjen prinsipper og arbeidsmetoder som jeg tenker er ganske likt seminar i min forståelse. Han beskriver gruppeundervisning som en arene for dialog- og diskusjonspreget undervisning i smågrupper. Det vil derfor være opp til emneansvalig og faglærer å bestemme innhold og form på undervisningsopplegget. Kanskje dette innebærer at en bør bli mer konsis på hva en mener med å kalle undervisningsformen seminar, hvorfor seminar bør brukes som undervisningsform i høgere utdanning, og hvordan det kan gjøres.

\section{Hvordan kan seminar brukes som undervisningsform?}

Jeg vil presentere et eksempel på hvordan et seminar ble gjennomført i emnet rådgivning og veiledning i pedagogiske virksomheter $1\left(\mathrm{RoV}_{1}\right)$, hvor empirien er hentet fra. I undervisningsplanen for RoV1 får studentene en oversikt over tema som skal gjennomgås den aktuelle uka. Det er en firetimers forelesning for alle studentene, og i tillegg er det samme uke seminar på tre timer. En av lærerne uttalte: «forelesningen som er avholdt på forhånd, gir en god ramme til påfølgende seminar». Faglærerne som deltar på seminaret, bruker tid sammen for å planlegge opplegget. Dette for at faglærerne skal stille med mest mulig lik tilnærming til seminaraktivitetene og tema. «Grundig planlegging og variasjon er en viktig faktor for et vellykket seminar», uttalte en faglærer.

Under er det tatt med et eksempel på hvordan undervisningsplanen så ut i uke 3 for studentene, og hvordan seminaret skulle gjennomføres. 


\begin{tabular}{|l|l|l|}
\hline Uke 3 & Kommunikasjon i veiledning & Veiledende lesing i pensum \\
\hline Tirsdag: 17.01 & - Kommunikasjon & Ulleberg; Del 1 av boka \\
10.15-14.00 & - Konflikthåndtering & Børresen; Kapittel 4 \\
Aud G & - Tverrfaglig samarbeid & Johannesen mfl.; Kapittel 6 \\
& & Skau; Kapittel 4 og 5 \\
Torsdag: 19.01 & Seminar: Kommunikasjon i veiledning & Tveiten; side 83-86 \\
09.15-12.00 & & \\
P-101, P-102 & & \\
\hline
\end{tabular}

Figur 1.2 Utdrag fra undervisningsplan for emnet.

Fokuset denne uken var «kommunikasjon i veiledning». Det ble gitt tips til veiledende lesing i pensum, og studentene fikk presentert tydelige forventninger om at de skulle møte forberedt til seminaret. Oppgavene for seminaret ble lagt ut i forkant, og vi forventet at studentene hadde satt seg inn i pensumstoffet før seminaret begynte. På den måten har studentene en forforståelse for tema kommunikasjon. De kan få nødvendige forutsetninger for å koble teori og praksis. På seminaret ble studentene delt inn i nye grupper ettersom hvilke øvelser som skulle gjennomføres. I etterkant av seminaret skal studentene skrive et refleksjonsnotat på 3-4 sider om opplevelser, tanker eller oppdagelser om emnet kommunikasjon.

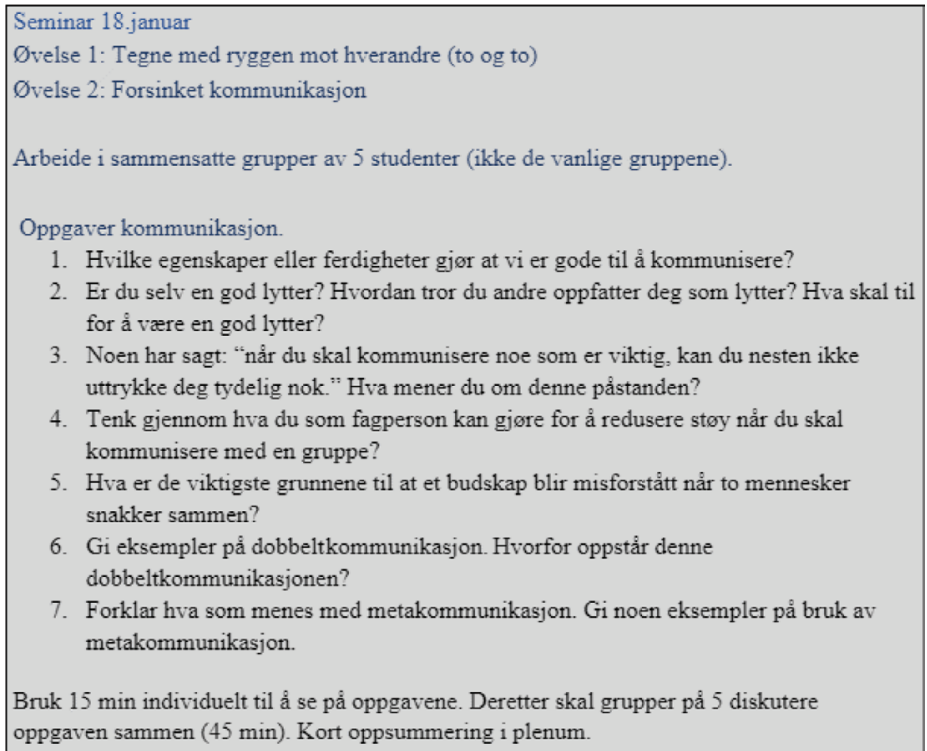

5. Hva er de viktigste grunnene til at et budskap blir misforstått når to mennesker snakker sammen?

6. Gi eksempler på dobbeltkommunikasjon. Hvorfor oppstår denne dobbeltkommunikasjonen?

7. Forklar hva som menes med metakommunikasjon. Gi noen eksempler på bruk av metakommunikasjon.

Bruk $15 \mathrm{~min}$ individuelt til å se på oppgavene. Deretter skal grupper på 5 diskutere oppgaven sammen (45 min). Kort oppsummering i plenum.

Figur 1.3 Eksempel fra deler av et seminar. 
Dette var beregnet til å ta 1 time og 30 minutter. Det vil si halve seminaret den torsdagen. En ser ut fra opplegget at vi startet med to øvelser i kommunikasjon. Den første øvelsen er at studentene skal jobbe sammen to og to. Den ene studenten har en enkel tegning foran seg på et ark, den andre studenten har et blankt ark. De skal stå med ryggen til hverandre. Studenten med tegningen skal forklare den andre studenten hva han/ hun skal tegne. Ettersom de ikke ser hverandre, vil beskrivelsen med ord være viktig. Det studentene oppdager, er at det er ganske vanskelig å forklare en enkel tegning på en måte som gjør at den andre studenten forstår hvordan tegningen skal se ut. Etter øvelsen reflekterer vi og snakker om hvordan kroppsspråk og talespråk kan være avhengig av hverandre og om hvor stor betydning kroppsspråk har i kommunikasjonen vår.

Den andre øvelsen går på forsinket kommunikasjon. Studentene går rundt i klasserommet og sier navn på det de tar på. For eksempel «et bord». Dette oppfatter alle som veldig lett. Deretter skal de forsinke kommunikasjonen. De tar på et bord, deretter på en genser og sier bord. Det vil si at de forsinker kommunikasjonen et ledd. Dette er heller ikke så vanskelig. Til slutt skal de forsinke kommunikasjonen enda et ledd og i tillegg beskrive gjenstanden de tar på med farge. De tar først på et bord, deretter en genser og så en lampe. Når de tar på lampen, skal de si et brunt bord, altså forsinke kommunikasjonen med tre ledd. Da begynner det å bli noe mer komplisert. Det studentene oppdager, er at det kan være vanskelig å ha flere tanker i hodet på en gang. Dette er viktig å få frem, da veiledning som fag handler om å være til stede i øyeblikket samtidig som du skal kunne tenke ett eller to steg videre i veiledningssamtalen.

Den siste oppgaven handler om å jobbe i grupper med gitte arbeidsoppgaver. Studentene skal først bruke tid på oppgavene individuelt før de skal diskutere i grupper på 4-5 studenter. På denne måten får de både repetert teori om kommunikasjon for seg selv og diskutert temaer om kommunikasjon sammen med andre studenter. Studentene gir uttrykk for at de får en bedre forståelse for teorien som ble gjennomgått i forelesning når de gjennom ulike aktiviteter kan bearbeide og utforske den etterpå. En student skriver: «ved å skrive et refleksjonsnotat fikk jeg oppsummert seminaret og samtidig repetert de viktige punktene som er godt å ta med seg videre i studiet. Når jeg skrev, merket jeg også at jeg reflekterte mer over 
hva vi gjorde og hvorfor noen spørsmål var bedre enn andre. Det å skrive et refleksjonsnotat har rett og slett vært lærerikt for meg».

På seminarene deler vi ofte studentene inn i grupper på 4-5 studenter. Studentene settes inn i en samarbeidssituasjon der de må forholde seg til hverandre. I tillegg til å erfare og lære om samarbeid får de muligheten til å utvide sine sosiale kontakter. Forskning forteller at samarbeid fører til bedre prestasjoner og større produktivitet. I tillegg kan en i samarbeid med andre oppleve flere støttende, omsorgsfulle og forpliktende relasjoner. Dette kan være positivt for å bedre psykisk helse, sosial kompetanse og mer realistisk selvoppfatning (Johnsen, Johnsen, Haugaløkken \& Aakevik, 2006). I seminarene varierer vi gruppesammensetningen ut fra hvilke tema vi jobber med. Små grupper gjør at alle må delta, og det er vanskelig for studenter å koble seg fra gruppen. Vi bruker mye tid i starten av emnet til å bli kjent og på å bli en trygg studentgruppe. I spørreundersøkelsen svarer mange studenter at de opplever at de har respekt for hverandre, de er engasjert, og de tør å by på seg selv. Deltagelse i små grupper kan synliggjøre styrker og svakheter hos den enkelte student. Min erfaring er at studentene stort sett er flinke til å dra med seg alle i gruppa.

Dette er et eksempel på hvordan seminar kan benyttes slik at studentene selv kan arbeide med fagstoffet og øke sin forståelse av kommunikasjon og dens betydning i rådgivning og veiledning. Gjennom ulike aktiviteter får studentene kjenne på og reflektere over teorigrunnlaget som ble forelest to dager i forkant av seminaret. De jobber individuelt og i grupper, deltar i fagdiskusjoner og refleksjon både i grupper og i form av arbeidskrav som refleksjonsnotatet etter seminaret. På den måten kan det bli enklere for studentene å koble sammen teori og praksis. Ser en tilbake til de generiske ferdighetene beskrevet i Melding til Stortinget 16 (2016/2017) (Kunnskapsdepartementet, 2017, s. 14), vil en se at gjennom øvelser vil studentene berøre flere av ferdighetene som stortingsmeldingen vektlegger i å gjøre studenten bedre rustet til å møte et samfunns- og arbeidsliv som krever kontinuerlig omstilling. Gjennom øvelser på seminaret får de utviklet seg i forhold til kommunikasjon og samarbeidsferdigheter ved at de arbeider i grupper. De får trening i selvrefleksjon gjennom felles refleksjon etter øvelsene og ved å skrive refleksjonsnotat i etterkant av 
seminaret. Studentene får mulighet til å utvikle sine sosiale og emosjonelle egenskaper gjennom samarbeid i grupper og refleksjon i etterkant. Kritisk tenkning kan studentene øve på ved å diskutere med medstudenter og faglærer. Ettersom studentgruppen er flerkulturelt sammensatt vil de også få mulighet til å utvikle en bredere samfunnsforståelse.

\section{Hvorfor bruke seminar som undervisningsform?}

Roar Pettersen (2005) henviser til Brandsford, Brawno og Cocking (2000) og deres bok How People Learn, hvor de har sett på nøkkelaspekter ved undervisning og læring. Studentsentrering, kunnskapssentrering og tilbakemelding på og kunnskap om egen læring er tre viktige aspekter ved undervisning og læring i høgere utdanning. Brandsford, Brawn og Cocking (Pettersen, 2005) skriver at alle studenter møter til undervisning med en etablert forståelse av hvordan verden fungerer. De hevder at hvis lærere ikke lykkes med å aktivisere studentenes forforståelse, er det ikke sikkert de vil klare å anvende den nye informasjonen utenfor undervisningsarenaen. Det er når den nye informasjonen forbindes med allerede etablerte kunnskapskonstruksjoner at ny forståelse kan utvikles og at misforståelser kan korrigeres. For oss som faglærere innebærer dette at vår undervisning må ta utgangspunkt i den forståelsen studentene allerede har (Wittek \& Brandmo, 2016).

$\AA$ aktivere og engasjere studentene blir i denne tenkningen som vist over, viktig. Ser en dette opp mot eksemplet fra seminaret, vil det si at alle studenter har erfaring med og mening om hva kommunikasjon er. Gjennom kommunikasjonsøvelser og refleksjon i etterkant kan de bygge videre på sin forforståelse om kommunikasjon. Det å koble teori og praktisk erfaring kan gjøre at de utvikler en dybdelæring i temaet kommunikasjon. Brandsford, Brawn og Cocking (2000) skriver at det er nødvendig for studentene å etablere en solid basiskunnskap som går i dybden i det fagområdet de skal utdannes innenfor. De snakker om dybdelæring, som kjennetegnes ved at man får tak i fagets underliggende strukturer og prinsipper (Pettersen, 2005). Derfor er det viktig at studenter forstår de tradisjoner, den historie og de mer konkrete kontekster som knytter seg til faget eller profesjonen. Skal studentene oppnå en kompetanse i å 
benytte seg av sin dybdekunnskap, må undervisningen organiseres slik at studentene får hjelp til å organisere kunnskapen på en helhetlig måte og forstå hvilken relevans den har for praksisfeltet. Ettersom studentene i emnet RoV 1 også skriver refleksjonsnotat, kan de få en tilbakemelding fra faglærer på sine tanker om øvelsene og den praktiske erfaringen de har opplevd. Tilbakemelding på og kunnskap om egen læring er et av aspektene Brandsford, Brawn og Cocking (2000) trekker fram i forhold til undervisning og læring. Et sentralt argument er at tilbakemeldingen må brukes for å støtte studentene i deres læring (Pettersen, 2005).

Forelesninger er fortsatt den undervisningsformen som er mest brukt i høgere utdanning i Norge (Bakken, 2018). Selv om forelesninger kan fungere godt, er de alene ikke spesielt godt egnet for dybdelæring. Dette taler for at forelesningen i større grad bør erstattes eller kombineres med undervisningsformer der studenten selv spiller en mer aktiv rolle (Kunnskapsdepartementet, 2017). Ut fra empirien, spørreskjema og emneevalueringen har jeg sett at en høy andel av studentene oppfatter seminaret som relevant i forhold til mestring og læring. 53 studenter sier de opplevde seminarene som en relevant arena hvor de opplever en økt mestring og læring i faget (figur under).

Spørsmålet: Hvor relevant har seminar vært for din opplevelse av mestring og læring $\mathrm{i}$ emnet?

Meget relevant -35 studenter

Noe relevant -18 studenter

Lite relevant -1 student

Antall svar: 54 studenter av 86 studenter

Det å se relevansen handler om å oppdage hvordan det studenten tenker og gjør, knyttes til det han/hun skal lære. Det er som å finne en ramme, oppdage puslespillets brikker og begynne å legge dem i system. Lave og Wenger beskriver det som situert læring. De skriver at all læring er situert, det vil si at den finner sted i en bestemt sammenheng av sosial og samfunnsmessig karakter som gjennom samspillet med den eller de som lærer, inngår som en integrert del av læringen (Lave \& Wenger, 1991). Det handler om et praksisperspektiv på læring som innebærer at kunnskap og læring anses som situert i menneskelige aktiviteter. Kunnskap er en 
integrert del av ulike praksiser med deres tradisjoner, redskaper og stedbundne forutsetninger. Erfaringene våre er intellektuelle og kroppslige samtidig. Tenkning er noe som skjer i samspill med artefakter og med andre mennesker i situerte praksiser. Vi er først og fremst sosiale vesener som samhandler med andre i ulike kommunikative prosjekter. Den intellektuelle nærheten til de sosiokulturelle og pragmatiske perspektivene på læring er åpenbar. Læring beskrives som en prosess, der nybegynneren tilegner seg kunnskaper og ferdigheter, men også holdninger, synspunkter og identitet gjennom legitim perifer deltagelse. Det som kjennetegner læring innenfor denne formen for praksisfellesskap, er at man ser og forstår hvordan deler og helhet henger sammen (Säljö, 2016). Dette kan lett relateres til studentaktive seminar. Studentene er i et fellesskap hvor de arbeider med fagstoff som er gjennomgått i forelesninger, eller som de har lest i pensum. De får diskutert, prøvd ut og reflektert over teori opp mot praksis. På den måten vil de få en dypere forståelse av kunnskapen. I en delundersøkelse i forskningsprosjektet ble studentene bedt om å beskrive seminar med tre ord. Det som var framtredende var ord som lærerikt, motiverende, utfordrende, engasjerende, gøy og forståelse for sammenhengen mellom teori og praksis.

Ved å lytte på en forelesning eller ved selvstudium kan studentene lære seg teorier, definisjoner og nye begreper. Men de trenger hjelp til å finne seg selv i situasjoner, se hvilken sammenheng teorier og definisjoner kan anvendes i og så bruke dem i praksis. På seminar kan de i små grupper få muligheten til å diskutere, løse konkrete oppgaver og bruke begrepene i praksis med mulighet til veiledning underveis. At de i etterkant skriver refleksjonsnotater, gjør at de i tillegg får bearbeidet fagstoffet flere ganger. Donald Schön (1987) skriver blant annet om skiftet mellom refleksjon i handling og refleksjon over handling. Kunnskap i handling kan beskrives som strategier, forståelse av fenomener og innfallsvinkler til å skissere en oppgave eller et problem. Kunnskap i handling er taus, spontan og tilføres uten bestemte overveielser. Refleksjon i handling har en kritisk funksjon. Refleksjon gir mulighet for å eksperimentere på stedet. Vi prøver ut nye handlinger med henblikk på å utforske de observerte fenomener, etterprøve vår forståelse av dem eller bekrefte det vi kan tenke for å gjøre det bedre (Schön, 1987). Ser en på refleksjonsnotatene fra studenter 
som er aktivt til stede på seminar, klarer de å reflektere og problematisere forståelsen av begreper på en mer utfyllende måte. En student skriver: «I dette seminaret lærte jeg mye, vi benytter oss av flere sentrale begreper jeg har lært gjennom emnet og sett hvordan vi benytter oss av kommunikasjon hele tiden og hvor viktig det er å beherske kommunikasjon både verbalt og nonverbalt». De har tilegnet seg en dypere forståelse for begrepet og klarer å se at teori og praksis er noe som henger sammen. På den måten kan de reflektere $i$ handlingen, men også over handlingen.

\section{Oppsummering}

Som faglærere i høgere utdanning har vi et ansvar for å tro på det vi gjør, og å være gode rollemodeller for studenter. Vi har et ansvar for å bidra til at studenter får utviklet sitt læringspotensial og at vi legger til rette for varierte og studentaktiviserende undervisningsformer. Noe av suksessfaktorene med seminarene er at de knytter sammen teori fra forelesningen med studentaktiviserende tilnærminger. På den måten hjelper faglærere i høgere utdanning studentene med å gripe fagets eller profesjonens spesialiserte kunnskap og konvensjoner i tillegg til personlig utvikling. De viktigste kommentarene fra faglærere er at «grundig planlegging og variasjon er en viktig faktor for et vellykket seminar» og at «engasjerte lærere gir engasjerte studenter». Studentene beskriver seminar som lærerikt, motiverende, utfordrende, engasjerende, gøy og at de får forståelse for sammenhengen mellom teori og praksis. Etter min erfaring er det slik at jo mer fremmøte og aktiv deltagelse på seminar jo bedre opplevelse får studentene av mestring og læring, som igjen gir bedre resultat på eksamen.

Ved å ta i bruk ulike læringsaktiviteter på seminaret kan vi lettere klare å koble teori og praksis. Unge studenter med forholdsvis lite livserfaring sliter med å trekke linjer fra pensum og til hva dette betyr for dem selv og andre i praksis. En faglærer uttalte: «Slik jeg ser seminarene, gir de en unik mulighet til å ta kunnskapen som er formidlet i forelesninger, og som er pensum, opp i en mer praktisk sammenheng og på en mer studentaktiviserende måte». Min erfaring er at studentene på seminaret, som vist i eksemplet, gjennomfører en konkret handling i kommunikasjon, 
de snakker om erfaringen og reflekterer over handlingen og får en dypere forståelse av handlingen.

Mine erfaringer og foreløpig analyse fra forskningsstudiet «Seminar som læringsarena i høgere utdanning» kan si oss at studentene får en bedre mulighet til å oppnå de generiske ferdighetene som er beskrevet i Melding til Stortinget 16 (2016/2017) (Kunnskapsdepartementet, 2017, s. 14). Studenten får trening i kritisk tenkning i diskusjoner på seminar, og å skrive refleksjonsnotat. Gjennom ulike gruppeoppgaver får studentene utviklet sine sosiale og emosjonelle egenskaper. Refleksjonsnotatene gir økt kompetanse i selvrefleksjon. Gjennom ulike aktiviteter får de trening i kommunikasjon og samarbeidsvaner. Studentene får en økt samfunnsbevissthet både med å arbeide med praksisnære case og det å jobbe i sammensatte studentgrupper med ulik kulturell bakgrunn.

\section{Litteratur}

Andersen, S. S. (2013). Case-studier og generalisering: forskningsstrategi og design. Bergen: Fagbokforlaget.

Bakken, P., Pedersen, L. F. \& Øygarden, K. F. (2018) Studiebarometeret 2017 hovedtendenser. Studiebarometeret: Rapport 1-2018 NOKUT.

Bransford, J. D., Brown, A. L. \& Cocking, R. R. (Red.) (200o). How people learn. Brain, mind, experience, and school. Washington, DC: National Academy Press.

Bø, I. \& Helle, L. (2008). Pedagogisk ordbok. 2. utgave. Oslo: Universitetsforlaget. Johnsen, D. W., Johnsen, R. T., Haugaløkken, O. Kr. \& Aakevik, A. O. (2006). Samarbeid i skolen. Pedagogisk utviklingsarbeid, samspill mellom mennesker. Namsos: Pedagogisk psykologisk forlag.

Kunnskapsdepartementet. (2017). Kultur for kvalitet i høyere utdanning (2016/2017). (Meld.St 16. (2016-2017)) Hentet februar 2017 fra https://www.regjeringen.no Lave, J. \& Wenger, E. (1991). Legitim perifer deltagelse. I K. Illeris (Red.) (2000), Tekster om loering. Roskilde: Roskilde Universitetsforlag.

Michelsen, S. \& Aamodt, P. O. (2007). Evaluering av Kvalitetsreformen Sluttrapporten. Oslo: Norges forskningsråd.

Nordkvelle, Y. (2011). Den visuelle vending i høyere utdanning: fra «det levende ord» til læreren som «performer». I Ø. Haaland, S. Dobson \& G. Haugsbakk (Red.), Pedagogikk for en nyere tid (s. 121-137). Vallset: Opplandske bokforlag.

Nordkvelle, Y. (2003). Om didaktikken i pedagogikkens skygge fra europeisk renessanse til i dag. Forskningsrapport nr. 102/2003. Lillehammer: Høgskolen i Lillehammer. 
PED 1006/1 inn.no emnebeskrivelse (u. d.). Rådgivning og veiledning i pedagogiske virksomheter 1 . Hentet fra https://www.inn.no

Pettersen, R. (2005). Kvalitetsloring i høyere utdanning. Innføring i problem- og praksisbasert didaktikk. Oslo: Universitetsforlaget.

Säljö, R. (2016). Lœring - en introduksjon til perspektiver og metaforer. Oslo:

Cappelen Damm Akademisk.

Schön, D. A. (1987). Education the reflective practitioner. San Francisco: Wiley Imprint.

Wittek, A. L. \& Brandmo, C. (2016). Om undervisning og læring. I H. Strømsø, K. H. Lycke, \& P. Lauvås (Red), Når loering er det viktigste. Undervisning i høyere utdanning. 2. utgave. Oslo: Cappelen Damm Akademisk. 



\title{
KAPITTEL 6
}

\section{Praksisnær undervisning med simulering og rollespill}

\author{
Yngve Nordkvelle og Odd Rune Stalheim \\ Høgskolen i Innlandet
}

\section{Trine Fossland}

UiT, Norges arktiske universitet

\section{Thomas de Lange, Line Wittek og Monika Bærøe Nerland \\ Universitetet i Oslo}

\begin{abstract}
Simulation in education involves creating situations that are similar to events, rituals and routines performed in the workplace - or in therapy, consultation, conflicts or similar situations. One recreates as many conditions as are necessary for the students to 'live' within what one imitates. Teachers instruct students and run the procedures as if they were 'reality'. Some simulations, such as in nursing education, require expensive equipment and sophisticated use of ICT. Others can be set up as role-playing games with what one has at their disposal in terms of facilities. The article compares three cases of simulation that were closely examined in connection with a research project. The purpose was to find out if the students experienced this as good quality. The students' ability to immerse themselves in the situation is of great importance for the benefit of the simulation. Most students find that the situations closely resemble real life and keep them engaged and alert. Teaching that explicitly tries to resemble reality is perceived as very educational.
\end{abstract}

Keywords: simulation, roleplay, student activity, learner centred, engaged teaching

Sitering av denne artikkelen: Nordkvelle, Y., Stalheim, O. R., Fossland, T., de Lange, T., Wittek, L. \& Nerland, M. B. (2020). Praksisnær undervisning med simulering og rollespill. I Y. T. Nordkvelle, L. Nyhus, A. Røisehagen og R. H. Røthe (Red.), Praksisnor undervisning - i praksis og teori (Kap. 6, s. 99-119). Oslo: Cappelen Damm Akademisk. https://doi.org/10.23865/noasp.94.ch6.

Lisens: CC BY 4.0. 


\section{Introduksjon ${ }^{1}$}

Et viktig siktemål for studier som søker å fylle gapet mellom teoretiske og praktiske sider av faget, er å gjenskape betingelser for læring slik at studenter kan ta med seg lærdommen og lett overføre den til arbeidspraksis de skal møte. Vi kjenner mange av disse fagenes historie som dypt forankret i laugenes tradisjoner. Et kjent eksempel er hvordan ingeniør- og arkitektstudenter i Italia gikk i lære hos anerkjente mestere og gradvis ble innlemmet i planleggingsarbeidet. Da mesterne organiserte studentene til konkurranse mellom grupper av studenter for å planlegge neste byggetrinn, tok man i bruk «progetti» - eller framoverskuende beskrivelser av hvordan belastninger, byggematerialer, design og funksjon kunne brukes for den videre byggeprosess. Dette ble kimen til prosjektmetoden, der studentene fikk ta del i en forestilt eller simulert praksis (Knoll, 1997). De blivende arkitektstudentene fikk stor tillit til å utføre prosjekter som ble verdsatt og gjennomført av de eldre og profesjonelle kollegene. Med prosjektmetoden, og etter hvert en lang rekke andre metoder, forsøkte en å skape arbeidslivets praksisform som normsettende og modellere undervisning og læring «som om» en er i arbeidspraksisen, der intensiteten og alvoret er langt sterkere. Så nær praksis var denne undervisningen at forskjellen knapt ble merket.

I dette kapitlet skal vi se på hvordan man gjennom tre ulike studier forsøker å skape denne illusjonen av virkelig praksis. I sykepleierutdanningen har stadig flere studier tatt i bruk simuleringslaboratorier, der studenter øver seg på livaktige dukker, der den norske dukken «Anne» hadde en banebrytende rolle. I jusutdanningen organiserer man rettssaker på bakgrunn av rettssaker som faktisk har foregått. Det tredje eksempelet er hentet fra hvordan man bruker rollespill for å skape realisme i undervisningstemaer som «rekruttering» innenfor økonomi og ledelsesfag. Alle tre studiene var en del av studien «Kvalitet i norsk høyere utdanning», og datainnsamlingen ble gjennomført i 2016 og 2017 ved norske læresteder.

1 En tidligere og kortere engelskspråklig versjon er publisert i Trimmer, K., Newman, T. \& Padró, F. (Red.) (2019). Ensuring Quality in Professional Education Volume I: Human Client Fields Pedagogy and Knowledge Structures 1. utg. London: Palgrave Macmillan. 


\section{Simulering som metode}

Eksempelet ovenfor med ingeniør- og arkitektstudier er hentet fra 1600-tallet, men allerede fra 1300-tallet benyttet man fingerte rettssaker som muligheter for studenter som skulle prøve seg som advokater, dommere og anklagere. Problemet med hvordan teori og praksis skulle forenes, har vært brysomt helt siden antikken, hevder Daly og Higgins (2011). I en klassisk framstilling av feltet sier Tansey og Unwin (1969) at gjennom bruk av simuleringer og ulike former for spill er man på vei til å bygge broer mellom teori og praksis, fordi det skillet som man har mellom de to i høyere utdanning, er både unaturlig og uheldig.

I dag har både simulering og spill som fenomen blitt forsket på i mange sammenhenger. Spørsmålet om teori og praksis faktisk oppleves som nærmere koblet eller ei, er fortsatt gjenstand for stor interesse, særlig innenfor studier som krever ferdighetstrening. I disse eksemplene var forskningsspørsmålet om forsøkene førte til en opplevelse av bedre kvalitet i studiene, og om design av simuleringsaktivitene var viktige for studentenes opplevelse av kvalitet i studiene.

Simulering i helsefagene er kanskje det fagfeltet som har mest oppmerksomhet i den studiefagdidaktiske forskningen. En klassisk definisjon av Rall og Dieckmann (2005) sier oss at simulering er

... å utføre noe «som om», eller å likne på «virkeligheten» (men ikke på noen perfekt måte, fordi da ville det nettopp være virkelighet), med andre ord for å trene på eller lære noe uten risikoen eller omkostningene med å gjøre det i virkeligheten. (2005, s. 274, forfatternes oversetting)

Fenomenet kan variere sterkt fra høyteknologiske simuleringer i marinteknologi til korte rollespill. I våre eksempler er simulering med svært sensitive dukker i et komplekst oppsett i et øvingslaboratorium eksempel på høyteknologisk simulering, mens rollespill i en jobbintervjusituasjon er eksempel på et lite teknologisk sofistikert oppsett, men med andre utfordrende elementer. Skal simuleringer oppleves som givende og realistiske, må lærerens ledelse av simuleringer være gode, studentene må være vel forberedt og engasjerte, de bør foregå i velprøvde undervisningsoppsett, og dramaturgien i simuleringen må være velegnet (Jeffries, 2005). Denne beskrivelsen understreker at lærernes omfattende innsats for å 
legge til rette godt materiale for simuleringen og for å veilede prosessen bør møtes av studenter som evner å utnytte situasjonen i simuleringen.

Lee Shulman (2002) definerte undervisning av høy kvalitet slik: Dersom undervisningen motiverer og engasjerer studenter, slik at de lærer seg stadig mer av sitt emne, får øvet seg i de ferdigheter som kreves, samtidig som de inviteres til refleksjon og kritisk vurdering i en prosess som former studentenes identifisering med fagområdet - da holder den høy kvalitet. I dagens debatt om hva som skaper kvalitet i høyere utdanning, blir tiltak som skaper større autentisitet og praksis-lik undervisning ofte trukket fram. I tråd med hva Shulman formulerte, framførte også Mjøsutvalget og etterfølgende stortingsmelding at «Den beste læring oppnås der studenten er intenst til stede med hele sin skaperkraft. (...) En større intensitet i utdanningen kan både frigjøre ressurser, øke gjennomstrømningen og gjøre utdanningen mer lærerik og givende for studenten» (Norge Kirke-, utdanning- og forskningsdepartementet, 2001).

I forbindelse med helsereformen i 2013 satte Universitets- og høgskolerådet i verk et større utredningsarbeid om hva som kunne øke kvaliteten i helse- og sosialfagutdanningene. I deres rapporter ble det framhevet at spill, rollespill og simuleringer har et stort potensial for å minske avstanden mellom undervisning i teoretiske emner og de praktiske treningssituasjonene de trenger innen hele helseområdet (se f.eks. UHR, 2016, s. 9). I det store utredningsarbeidet "Advokaten i samfunnet» (NOU 2015:3) kan vi lese liknende forhåpninger til at juridikum vil øke sin innsats på samme området. Debatten innen økonomi og ledelsesfag har vært tilsvarende kritisk til at emner undervises uten synderlig kontakt med arbeidslivet, og at det fordres flere tiltak som knytter praksis og akademia nærmere - til «prakademisk» undervisning, som Jørgensen, Skyttermoen og Syversen (2011) har navngitt dette utviklingsområdet.

Problemet i opplæring som bruker simulering, er å skape situasjoner og læringskontekster som studenter vil anerkjenne som så autentiske at de går inn i disse situasjonene med oppriktighet og vilje til å prøve seg selv og medstudenter i mer krevende og intense læringssituasjoner. Skal dette lykkes må simuleringene være a) forankret i reelle situasjoner og erfaringer, b) fordre at kritisk tenkning fremmes og at spørsmål stilles, c) at den involverer flere i et lærende fellesskap, og at d) dette fellesskapet opplever 
en styrket faglig og personlig identitet etter simuleringen (empowerment) (Rule, 2006). Dersom man har et håp om at studentene skal være «intenst til stede med hele sin skaperkraft», som det ble uttrykt i stortingsmeldingen, må kvaliteten på den dramaturgien simuleringen bygger på, være tilsvarende medrivende og troverdig, og de aktørene som engasjerer seg, må være av samme kaliber (Reid-Searl, Eaton, Vieth \& Happell, 2011). Keskitalo og Ruokamo (2016) skriver at selv om dette er sterke krav, oppleves simuleringer innen helsefag som meningsfull læring, og de vurderer simuleringsaktiviteter høyt når det gjelder erfart læringsutbytte - både på det faglige, personlige og sosiale nivå.

Å engasjere studenter er en krevende øvelse (Skodvin, 2016). Norske studenter kan være en særskilt utfordring, skal man tro David Croxford (2001), som med erfaring som gjestelærer i en rekke land karakteriserte norske studenter som særdeles durkdrevne i å unngå å engasjere seg i undervisningen. Selv om denne beskrivelsen ble brukt om forelesningen som sjanger, kan det være kulturelle forhold som i noen grad hemmer studenter i å engasjere seg følelsesmessig og kognitivt. I simuleringssituasjoner skal studentene også forstå noen rammer og sammenhenger rundt situasjonen som krever oppmerksomhet. En av disse er en avansert teknologi som en simuleringsdukke, eller en boremaskin på havets bunn. I tillegg skal man kommunisere adekvat, tenke i alternativer og utøve skjønn - og til sist evne å reflektere kritisk over det som simuleringen eller rollespillet brakte fram (Tosterud, 2015b). Studentenes evne til å tre ut av den motstandsdyktige rollen som tilhører og inn i en rolle som krever intens tilstedeværelse, vil være en kritisk faktor om simuleringer og rollespill skal heve kvaliteten på utdanningen.

Når studenten er invitert inn i slike krevende situasjoner, er det interessant å se hvilke kognitive, sosiale og emosjonelle skjema som aktiveres for å løse kompleksiteten i dem. Hvilke teoretiske og praktiske momenter som trekkes inn i situasjonen og spørsmålet om hvordan skjønn og utøverkunnskap balanseres mot vitenskapelighet er viktig, ikke minst siden «evidence»-fenomenet i økende grad setter sitt preg på disiplin- og profesjonsstudier. Innen læresteder og innen emner og fag er det en kontinuerlig rivalisering mellom den punktfestede, teoretiske framstilte teori og utøverens praktiske skjønn, og gapet mellom teoriens og praksisens ulike 
tyrannier (Kvernbekk, 1995), er ikke lett å fylle (Colley, 2003; Thomas \& Wilson, 2011). Når simuleringer og andre tiltak trekkes inn, vil det tilsynelatende alltid være slik at den til enhver tid dominerende teoretiske forståelse har større troverdighet i akademia, enn den praktiske utøverkunnskap. De hendelsene og prosessene som får studentene til å kjenne igjen mønster fra tidligere erfaringer og deres lesing av teoretisk fagstoff, og skape nye samband mellom dem når de står i situasjonene som krever deres aktive deltakelse, skal så bearbeides videre. Når simuleringen er utført, skapes det rom for å gå tilbake i erindringen, tenke over valg som ble gjort, og diskutere alternativ(er) og hvordan verdiene av de erfaringene som faktisk ble gjort kan overføres til andre situasjoner. Det er summen av disse som ifølge Schaffer (2012, s. 403) avgjør om kvaliteten er god eller ei.

Feltets teoretikere framhever at simuleringer som bringer fram studentenes tidligere erfaringer, og gir studentene anledning til å skape personlige utgaver av feltets standard viten, bidrar til at studentene får en handlingsbase eller opererbar kunnskap de kan ta i bruk i de kommende praktiske situasjonene. Markauskaite og Goodyear (2016) beskriver dette som at studentene må skape en «epistemic fluency», som gir studentene et register av strategier for å møte ulike utfordringer i ulike situasjoner. I simuleringer aktiveres alle lærte teorier, ideer og handlingsdisposisjoner og kommer «i flyt» før studentene velger blant dem, tar dem i bruk og finner en måte å handle på som gir mening for dem. Når man er i «flyt» er man i stand til å skifte standpunkt, teste alternativer, se sammenhenger - og endre posisjoner - med letthet og med produktivt utfall. Det er i slike læringssituasjoner opplevelsen blir intens og engasjerende, oppslukende og interaktiv på måter som får studentene til å lære mer og mer autentisk (Gresalfi \& Barab, 2011). Prosedyrer, konsepter, konsekvenser av handlinger som ble utført, og kritisk ettertanke over valg som ble tatt, blir til håndfaste handlingsalternativ basert på økende grad av sikkerhet - eller økende grad av «flyt».

\section{Tre eksempler}

I forskningsprosjektet "Quality of Norwegian Higher Education: Pathways, Practices and Performances» undersøkte forfatterne tre ulike utdanninger der man benyttet rollespill og simulering, for å oppnå en 
bedre sammenheng mellom teori og praksis. I forskningen ble det brukt observasjon gjennom deltakelse, intervjuer, videoopptak og analyser av dokumenter som brukes i studiene. Emneplaner, studieplaner og instruksjoner ble også brukt som bakgrunn for å forstå studienes intensjoner og tilrettelegging. Eksemplene framstilles som fortellinger om hva som ble sett og opplevd (Nerland \& Prøitz, 2018).

\section{Simulering i sykepleiestudiet}

Den norske dukken Anne, som ble utviklet av Åsmund Lærdal, ga på mange måter støtet til den moderne opplæringen med bruk av dukker. Førstehjelpsopplæringen fikk et stort løft da dukken, som var livaktig og responderte på naturlig vis på de manipulasjonene man utførte, snart ble brukt over det ganske land, og etter hvert også internasjonalt. Siden starten omkring 1960 har denne dukken, og en rekke andre systemer, blitt utstyrt med datateknologi og sensorer for temperatur, væske, taktile kontakter og audiovisuell kommunikasjon. På mange måter har disse simuleringsdukkene blitt et svar på mange utfordringer innenfor problembasert læring, og de blir derfor sett på som en viktig fornyer innen opplæring av medisinsk personell (Bradley, 2006).

Det emnet som ble studert het «Veiledet praksis i klinisk sykepleie». Studentene var deltidsstudenter som tok den treårige bachelorutdanning på fire år. I emneplanen er det satt opp læringsmål som skal dyktiggjøre studentene til å handle i forhold til akuttmedisin, med kronisk og kritisk syke pasienter, og de skal lære seg å arbeide i det sykepleiefaglige fysiske rom. Her kreves også at studentene reflekterer over de sykepleiefaglige øvelser som gjøres, og hvordan de observerer, samler informasjon og vurderer sin egen personlige og profesjonelle utvikling. Som ett av de generelle kompetansemålene trekkes også etisk og akademisk diskusjon inn, og evnen til å samarbeide og vurdere etiske konsekvenser. Den simuleringen vi studerte, fant sted i studiets andre år, i det andre semesteret, og var en integrert del av et praksisemne som omfattet 15 studiepoeng. Like før dette hadde studentene tilbrakt to uker på en sykehuspost der de ble veiledet av en praksisveileder.

Ei uke før simuleringen hadde studentene tilgang til informasjon om den casen de skulle møte. Informasjon om skaden eller lidelsen kunne 
de lese om på et faktaark, og de kunne finne mer informasjon gjennom vanlig tilgjengelige kilder. Studiets lærere valgte casen ut fra sin samling av caser som er utviklet av dem og prøvd ved tidligere anledninger. Før simuleringen gikk lærerne gjennom casen i et rom for samtaler og orientering, og så inn i simuleringsrommet, som likner på en ordinær post på sykehuset med en pasient liggende i ei seng. Den ene læreren som var til stede under simuleringen, ble kalt en fasilitator, mens den andre læreren styrte dukkens reaksjoner fra en posisjon i et tilstøtende rom med enveis glass, og ble kalt operatøren gjennom øvelsen. Operatøren spiller rollen som pasient fra sin posisjon i det andre rommet, men fasilitatoren er til stede med hodetelefon med mikrofon. Dukken i sengen ble så aktivert fra operatørens side og fikk de avanserte egenskapene som gjør den livaktig: stemme, blodtrykk, puls osv.

I simuleringen ble to studenter valgt til å gjøre øvelsen i rommet. Den ene skulle lede og den andre assistere. De øvrige seks studentene gikk tilbake til «refleksjonsrommet» og observerte simuleringen på stor skjerm. Den ledende sykepleieren snakket med høy og tydelig stemme og spurte pasienten spørsmål som: «Har du det bra nå herr Hansen?». Pasienten svarte fortløpende om hvordan han oppfattet sin tilstand og hvordan han opplevde å få støttet opp en arm, rettet på puta og så videre. Sykepleierstudentene snakket eksplisitt om hva pasienten kunne vente seg, og sjekket at det ble oppfattet, og om det førte til lindring eller ikke. Seg i mellom var de eksplisitte i samtalen om prosedyrer og rekkefølge: Blodtrykket ble målt før overkroppen ble hevet, kroppsvekt og -temperatur vurdert før riktig mengde smertestillende ble gitt. De viste sterkt engasjement og innlevelse i situasjonen, og var nøye med å gjøre ting riktig. Selv om lærerne på forhånd hadde fortalt at man også kan lære mye av å gjøre ting galt, var studentene bekymret for hva medstudentene ville finne av kritiske punkter. Mange studenter kjente historiene om de gangene en simulering hadde gått riktig galt og pasienten «mistet livet».

Fasilitatoren var ikke bare usynlig til stede. Da sykepleierne et øyeblikk var i stuss over hvor smertestillende medisin var å finne, trådte hun fram og hvisket hvor den sannsynligvis var. Da sykepleieren fant det riktig å konsultere legen per telefon, agerte fasilitatoren lege og svarte «som lege» på de spørsmål som ble reist gjennom hodesettet. Sykepleiernes 
eksplisitte tale og handlinger ble observert og vurdert av medstudentene, og selv om de ikke kan høres, førte de en lavmælt samtale om at «Jeg ville ha ...» eller «... de har allerede målt tempen».

Etter om lag 15 minutter tones simuleringen ut og sykepleierlærerne samles med alle studentene i «refleksjonsrommet». Lærerne startet med å rose studentenes evne til å leve seg inn i situasjonen og spille sin rolle. Medstudentene støttet dette med å si at de var gode skuespillere! Lærerne debrifet studentene gjennom den innarbeidede ABCDE-listen for sykepleiefaglig handling, der studentenes løsninger ble vurdert punkt for punkt, og medstudentene ble trukket inn for vurderinger av de løsningene som ble valgt. Lærerne balanserte mellom å sjekke at standard rutine var forstått og etterlevd, og å framheve punkter der vurderinger og ettertanke kunne peke på bedre valg eller skifte av perspektiv. Lærerne brukte egne erfaringer og eksempler for å belyse hvordan detaljer, dramatiske situasjoner, eller til og med tilfeldigheter, hadde endret bildet og handlingene. Studentene deltok med stor iver og stilte spørsmål når deres erfaringer og teoretiske innsikter ble brynet.

Lærerne betonte at det er utfordrende å finne balansen mellom å utfordre og å støtte studentene. Studentene syntes på sin side at de kunne være svært bekymret for å gjøre ting i gal rekkefølge, huske feil, velge feil prosedyre og bedømme situasjonen forkjært. Vissheten om at de andre studentene så dem, øket deres spenning. De fant lite trøst i at nettopp dette ga medstudentene anledning til å skjerpe sine observasjoner og øving i å fremme faglig kritikk. Selv om simuleringen hadde et tydelig «script», var det tydelig at improvisasjon og pedagogisk fantasi spilte inn og skapte en dramatisk nerve.

\section{Andre case: rollespill i personalutvikling og ledelse}

Dette undervisningsfeltet har også vært utsatt for mye kritikk for sin tendens til akademisering, og mange mener behovet for en reorientering mot det profesjonelle og praktiske er stort (Jørgensen mfl., 2013). Fagets historikere peker på at simuleringer og spill ble utbredt på 1950-tallet ved de store amerikanske «business schools» (Keys \& Wolfe, 1990), og at den digitale utvikling gjorde dataspill og virtuelle rollespill til en del av studietilbudene. Det rollespillet vi fulgte forskningsmessig, var imidlertid 
analogt, og var en del av et 7,5 poengs emne $\mathrm{i}$ "grunnleggende personalbehandling» i studentenes andre studieår i en bachelor i personalutvikling og ledelse. Tema som organisering, rekruttering, motivasjon og belønning i virksomheten var viktige områder i undervisningen. Rollespillet skulle gi studentene en nær opplevelse av hvordan rekruttering foregår, og studentene skulle erfare hvordan en personalavdeling kan støtte nyansatte gjennom den første fasen av å komme inn i virksomheten. Fagmiljøet hadde utviklet en overordnet didaktisk ide om å gjøre studiet «prakademisk» - et selvutviklet konsept for å synliggjøre behovet for å gjøre praktiske øvelser i tett samband med læring av teori.

I øvelsen skrev alle deltakerne en søknad på jobb hos «virksomheten», og gruppen valgte to søkere til å ha en jobbsøkerrolle, mens de øvrige gruppedeltakerne intervjuet og tok notater. Hele seansen varte i 4,5 timer, der den første halvtimen gikk med til forklaring av oppdraget, og den neste til organiseringen av intervjuet, laging av spørsmål og så videre. Det første intervjuet tok også en halv time, og deretter reflekterte teamet over hva som ble sagt og gjort, og lærdom for neste runde ble tatt ad notam. Denne sekvensen ble gjentatt for et nytt intervju, og det hele avrundet med en felles diskusjon i plenum. Gruppene i klassen skrev så en oppsummering av erfaringene som ble gjort, og relevante kilder fra pensum skulle trekkes inn for å belyse hendelsene, valgene og erfaringene.

Hele arbeidsøkta var altså bygd opp i 30 minutters bolker.

1. 30 minutter til introduksjon i plenum

2. 30 minutter til å organisere intervjuene og skrive ned spørsmål

3. 30 minutter til første intervju

4. 30 minutter med felles ettertanke og diskusjon med en gruppe med observasjonsoppgaver

5. (3 og 4 ble så repetert for det andre intervjuet)

6. 30 minutter til diskusjon om hele prosessen

Gruppene skrev så et refleksjonsnotat for hvordan gruppen opplevde rollespillet i forhold til studiematerialet og andre kilder.

De aller fleste studentene virket meget engasjert i aktiviteten. Noen av dem fikk doble roller som «jobbsøker» og «intervjuer». De som valgte å være så aktive, medga at de var ganske nervøse for sine rolleutførelser i 
møte med medstudenter før øvelsen startet. Noen studenter hadde forberedt seg svært godt ved å skrive ut intervjuguiden, og ved at de hadde lest jobbsøknadene godt før intervjuet. Noen grupper utførte øvelsen nøyaktig slik de var instruert til å gjøre. Andre valgte en mindre dirigert vei. Særlig kom denne forskjellen til syne når de skulle gi tilbakemelding til hverandre på hvordan de hadde løst oppgaven som intervjuer. De som fulgte instruksjonene nøye, tok også denne delen seriøst, mens i andre grupper tok prosessen mer løse former. Noen studenter maktet ikke å te seg seriøst i situasjonen, noe som kan indikere at studenter trenger øving i slike situasjoner. I ett tilfelle, der «søkeren» (som var framstilt som en erfaren HR-administrator i sin søknad, gift og med to barn) ikke maktet å holde seg alvorlig, ble utbyttet svært mye dårligere for resten av gruppa. Denne forskjellen i evnen til å følge instruksjoner og legge alvor inn i øvelsen skapte også et klart skille i studentgruppa. De seriøse studentene maktet å utvikle klare kriterier for hvem man burde «ansette», og gjennomførte grundige samtaler med argumentasjon for hvordan søkerne burde rangeres. Selv om også mindre seriøse grupper gjennomførte øvelsene, var kriteriene og argumentasjonen klart mindre grundige.

Til tross for denne variasjonen var den dominerende oppfatningen blant studentene at øvelsen hadde vært både nyttig og spennende, med et godt opplevd utbytte. De argumenterte bredt og godt for at et slikt rollespill hadde verdi. Først og fremst la de vekt på at den praktiske riggingen av situasjonen ga stor innsikt i hva en slik prosess krever av forarbeid, deltakelse og etterarbeid. Selv om de var på begge sider av bordet, ble situasjonen opplevd som realistisk og nyttig. De fant ut at de hadde tatt mange ting for gitt. De forsto bedre hvor viktig det var å forberede seg til intervju, og hvor viktig og vanskelig intervjuet var for begge parter. Det andre forholdet de pekte på, var verdien av å leve seg inn i intensiteten i intervjusituasjonen, som, for det tredje, ga dem en viktig impuls til å forstå hvordan dynamikken mellom det å være intervjuer og det å bli intervjuet utfolder seg. De erfarte hvordan fordommer og ureflekterte antakelser kan spille inn. Til sist sa mange at de syntes mange poenger $\mathrm{i}$ studielitteraturen ble anskueliggjort i øvelsen.

Den vanskeligste delen for studentene var å sortere kriterier og begrunne rangering. I denne fasen erfarte mange hvor vanskelig det er å være kritisk 
til hverandre. Likevel satte de pris på å få en ærlig tilbakemelding på hvordan de hadde løst oppgaven i andres øyne. En student beskrev det slik: «Jeg ble klar over ting jeg gjorde - og som jeg ikke ante at jeg gjorde».

Klassens lærer var ikke involvert i selve rollespillet, men hadde en meget tydelig hånd gjennom å legge til rette instruksjoner og oppskrifter for gjennomføringen. Hun fortalte at studentene ble overrasket over hvor krevende det var å lage en seriøs jobbsøknad. Å tenke seg en jobb og så beskrive sine fortrinn med hensyn til å få jobben var en sterk øyeåpner for studentene. Hun sa i intervjuet at: «Både intervjuerrollen og søkerrollen byr på viktig læring. Selv om det er krevende, sier alle at refleksjonen i etterkant var interessant og viktig, særlig med hensyn til hvor viktig det var å forberede seg godt.» Engasjementet og samarbeidet er viktig for at alle studentene skal oppleve det, og at de evner å gjennomføre begge rundene med intervjuer. Hun forklarte at «dersom forberedelsene er utilstrekkelige, kan fallet bli stort, og opplevelsen av å mislykkes bli lei. Derfor er det så viktig å gjennomføre andre runde. Det er som en ny sjanse der studenter flest skjerper seg, og det stimulerer refleksjonene på en bedre måte».

\section{Case 3: Simulert rettssal i juridisk utdanning}

Tradisjonen med å bruke juridisk utøvelse på tenkte eller lagde scenarier er gammel i de juridiske fags utdanningshistorie. I det 14. århundret ble såkalte «moots» eller «mock trials» brukt i opplæringen av jurister i England, og den har fortsatt i ulike former og varianter. Rettssaker har spilt en stor rolle i populærkulturen, og Juristforeningen sto for filming av fiktive rettssaker på NRK sendt i beste sendetid helt fra norsk fjernsyns barndom og med store seerskarer. Når studenter kler rollene som aktor, dommer, forsvarer eller andre konstellasjoner, avhengig av hvor saken er i behandling, søker en å gjenskape den spenning og alvor som preger «ekte» rettssaler. I USA er «mooting»-tradisjonene videreført i den dominerende casemetodikken i deres juridiske utdanninger (Daly \& Higgins, 2011).

I den valgte casen er kurset kalt «Kriminalrett i nye gevanter». I beskrivelsen av læringsutbyttet er det forventet at studentene skal utvikle «kunnskapen, ferdighetene og generelle kompetanser som er nødvendige 
for å arbeide som jurister i offentlige eller private virksomheter». Med dette som mål er kurset organisert slik at studentene får øve seg i prosedyrer som preger arbeidet i rettssalen. Hensikten er at studentene skal utvikle en forståelse av hvordan nærme seg, strukturere og presentere et juridisk saksforhold i realistiske omgivelser.

I seminarene ble studentene tildelt roller som forsvarere og påtalemakt, som taler fra hver sin posisjon i rettsalen. Deltakerne fikk tildelt anonymiserte beskrivelser av et juridisk saksforhold der dommen allerede var felt, og dette bidro til en følt autentisitet og realisme. Studentene fikk også presentert en rekke juridiske dokument som fulgte saken - som utskrifter av vitneavhør, papirer fra helsemyndigheter, politirapporter osv. Studentene fikk to-tre dager på seg for å lese dokumentene og forberede seg på hva de ville si og legge vekt på i rettshøringen. I god tid før den forestående intense øvelsen i retten var de instruert i hvordan slike saker foregikk. De hadde besøkt ekte rettssaler og fått øving i å «skrive saker», samt fått forelest over de viktigste rettslige prinsippene som ville komme til anvendelse.

I simuleringen var studentene gitt roller som forsvarere og aktorer, og i et rom som var organisert som et ekte rettslokale. I situasjonen var det deres lærere som inntok plassene som dommere. En ekstern juslærer hadde rollen som observatør og kommentator etter at spillet var gjennomført. Både forsvarer og aktor hadde hver sin juridiske assistent ved sitt bord. De øvrige studentene var på den ene siden alminnelige tilhørere, men hadde også oppgaven med å skrive et forslag til dom etter rettsforhandlingene. På det viset ble alle studentene involvert.

Studentenes forberedelser til selve rettssaken var organisert som obligatorisk gruppearbeid. I den fasen arbeidet studenter og lærere tett sammen, som om de arbeidet i et juridisk fagfellesskap. Hensikten var igjen å skape en situasjon som var mest mulig lik det arbeidsmiljø som preger slike, som et dommerembete eller en travel advokatvirksomhet i dagene før en viktig sak skal føres for retten. Da saken startet, var fysiske omgivelser, prosedyrer, tidsrammer og arbeidsdynamikk utformet svært likt det som utfolder seg i vanlig rettspraksis for å optimalisere praksisnærheten. Tilbakemeldingene fra dommeren og observatøren, som begge var erfarne jurister, i etterkant var rikholdige og ga en balanse i 
observasjonene fra ulike steder i salen. Studentene som var tilhørere, ga sin respons på hvordan forsvarer og aktor hadde framstilt saken. Ekstern lærer la fram sin vurdering av aktor og forsvarer ut fra sin lange erfaring fra rettssalen. Dommeren, eller deres faglærer i jus, ga til slutt sin vurdering av hvordan de juridiske prinsipper og kutymer var holdt i hevd og utøvd på riktig måte. Det var med andre ord et mangfold av tilbakemeldinger å høste fra for studentene.

I intervjuene med studentene som ble gjort i etterkant, viste de til at dommerne hadde ulik evne til å gi tilbakemeldinger som var direkte, spesifikk og individuell, og at den eksterne observatøren også kunne gått tettere på studentenes måte å løse forsvarer og aktor-rollen på. Studentene følte seg ganske stresset i situasjonen, og hadde forventet en ærligere og mer kritisk tilbakemelding enn de fikk. Til tross for det uttrykte de stor tilfredshet med å ha fått den type erfaring som meget relevant og troverdig. Det ble uttrykt at de «følte seg som en ekte advokat» og at de fikk gode gløtt inn i «en virkelig opplevelse av det framtidige arbeidet» de utdannet seg for. De kritiske røstene til tross så var det stor samstemmighet om at øvelsen hadde vært utfordrende og ble høyt verdsatt. Observatøren uttrykte stor tilfredshet med at studentene hadde forberedt seg godt og hadde tedd seg kreativt og løsningsorientert i rettssalen.

\section{En engasjerende pedagogikk?}

I casene som her er svært kortfattet framstilt, ser vi at simuleringer og rollespill er tatt i bruk for å redusere problemene vi ofte kjenner til som avstand mellom teoretisk kunnskap som studiene presenterer, og den praktiske sammenhengen der kunnskapen skal anvendes. I casene er dette presentert som en alternativ pedagogisk metode som er flettet inn i en rekke av emner som ellers kan være undervist ganske konvensjonelt. De har viktige fellestrekk: Studentene får en viss tid til å forberede seg - fra to dager til ei uke - før øvelsen gjøres, og til slutt foregår det en debrifing. De pedagogiske kontekstene er ulike, men fagets lærere er opptatt av å skape læringssituasjoner som forsøker å binde sammen og koble mellom det å vite «at og om» og det å vite «hvordan». 
I casen fra sykepleien foregår det i en høyteknologisk setting med sofistikert utstyr og nøye designede omgivelser. Omgivelsene sørger for høy grad av sikkerhet slik at pasienter ikke skal skades. Juscasen og rollespillet i personalutvikling og ledelsesfag utføres med konvensjonell tilrettelegging, men med tilgang til ekstern ekspertise i juscasen og ekstra ressurser i form av grupperom i jobbintervjuet. Personalutvikling og jus-casene er preget av mye skriftlig arbeid i forberedelser og etterarbeid, mens sykepleiens simulering er preget av muntlighet og fysisk nærvær i løsningen av tekniske utførelser av omsorg og pleie. Alle casene bærer preg av at noen studenter får mer deltakende og intense roller, mens andre får observatøroppgaver.

Øvelsen i organisasjons- og ledelsesfag er et tilbud til hele klassen, der alle involveres, men alle eksemplene viser at studentene kan velge posisjoner som utfordrer på ulike måter: noen mer, noen mindre. Et viktig fellestrekk var at samtlige studenter uttrykte entusiasme over simuleringene, og at nettopp denne øvelsen var høydepunktet i dette emnet. De uttrykker at de er overrasket over nivået på innlevelse, emosjonelt og kognitivt, og gir stor åtgaum til at øvingssituasjonen ble opplevd som autentisk og realistisk. Når de ytrer seg kritisk, er det fordi de ikke fatter at det ikke er flere slike situasjoner i løpet av studiet.

Disse eksemplene demonstrerer at studentenes evne og vilje til å engasjere seg i simuleringen er viktig, både som deltakere i simuleringens kjerne og som observatører. Studentene må kunne involvere seg «som om» det virkelig er slik situasjonen spilles ut. De som ikke kommer over terskelen for seriøst engasjement, får lite ut av øvelsene i form av saklig kunnskap eller prosedyreferdigheter. Noen studenter går inn i rollene med stor entusiasme og ter seg «naturlige», mens andre bruker lengre tid eller holder mer avstand i situasjonene som inviterer til å være helt til stede i dramaet. Det «å gjøre feil» ses ikke på som problematisk, i prinsippet, fordi dette kan skape større emosjonell tilslutning, provosere fram flere meninger og derved stimulere refleksjonene ytterligere. På den annen side føler studentene seg sårbare i situasjonene. De liker ikke å eksponere eventuelle mangler i kompetanse eller usikkerhet. De skal jo også passe på sin posisjon og status i studentgruppa og vet at lærerne kan notere dette som negative elementer for seinere vurderinger. 


\section{Øker simuleringer kvaliteten i studiene?}

Når Jeffries (2005) estimerer forhold som avgjør om en simulering er av høy kvalitet eller ei, er det fire forhold som er viktige. Ett er lærerens intervensjoner i simuleringen og et annet er nivået på studentenes forberedelser. Det tredje er simuleringens design og til sist hvordan simuleringen er plassert i studiets ordinære undervisningspraksis. Det siste peker på at det vil bedre studentenes evne til å leve seg inn med engasjement dersom dette forekommer ofte og på varierte måter i flere emner. Simuleringsdesignet kan utformes ulikt fra kontekst til kontekst, og måten læreren legger opp til studenters og egen agering i simuleringen på, kan opplagt variere. De tre eksemplene viser variasjon over disse forholdene, og uansett vurderer studentene opplevelsen av simulering som sterkt engasjerende, motiverende og faglig utfordrende. Selv om dette er målt etter observasjoner, intervjuer og feltarbeid, synes det som om Shulmans (2002) kriterier om at studier som motiverer studentene, holder dem fanget i høy grad av involvering, stimulerer til grundige refleksjoner og diskusjoner som øker handlekraft og trygghet i deres yrkesmessige forberedelser, nettopp kan smykke seg med et kvalitetsstempel. I eksemplene ser vi at simuleringene skaper slike følelser, ikke alltid eller hele tiden for alle, men likevel en sterk opplevelse av realisme og autentisitet. Situasjonene skaper en flyt for studentene som kombinerer utfordring og ivaretakelse, og debrifing som åpner refleksjoner mellom opplevelsene og den faglige eller boklige lærdom de trekker på i de epistemiske spill som kom til live gjennom dem. De peker alle i retning av at evnen til å la seg føre inn i simuleringsuniverset er en viktig forutsetning for at studentene skal kunne oppnå ønsket læringsutbytte (Tosterud, 2015b).

I eksemplene med personal- og ledelsesfagene er hele klassen involvert, men det var langt fra hele kullet som møtte. Jusstudentene ble engasjert i seks grupper à fire studenter som bar den dramatiske byrden fra studentenes side, mens resten av klassen hadde mer perifere roller. I sykepleiersimuleringen var det to studenter som fikk prøvd sine ferdigheter, mens resten av gruppen fulgte nøye med. Det er en stor utfordring å involvere en stor gruppe i simulering. Rullering i studentgruppen er en løsning man må benytte dersom det er knapt med plass. I eksempelet fra sykepleiestudiet er rammene i sterkere grad satt med kompleks teknologi og utforming av 
de rommene som brukes. Jo mindre teknologi og bygningsmessige krav, jo lettere er det å engasjere større studentgrupper, selv om undervisning som ikke er framstilt som obligatorisk synes å bli mindre oppsøkt av studenter. I sykepleierstudiet er læring av spesifikke ferdigheter opplagt en mer kritisk faktor og sett på som mer alvorlig enn de ferdighetene jusstudentene skal tilegne seg i et lettere tilrettelagt rettslokale eller ledelsesstudentens jobbintervju. Behovet for å lære en bestemt drill i gjennomføring og debrifing på en faglig god og sikker måte er like viktig som den etterfølgende refleksjon og den uavhengige og velbegrunnede avgjørelsen. Vi ser at intensitet og perspektiv endrer seg for studentene alt etter hvilken rolle de blir utpekt til eller velger å ta (Gresalfi \& Barab, 2011).

Da vi spurte sykepleierstudentene i etterkant om de opplevde simuleringen som en praktisk eller teoretisk læringssituasjon, var svaret umiddelbart at «dette er teoriundervisning» - eller en «utsøkt teoretisk læringsopplevelse». Til tross for at ordbruken ellers pekte i retning av at opplevelsen var svært konkret og praktisk, med sterkt engasjement og identifisering med «som om»-situasjonen, var det likevel et skille mellom dette og «den virkelige praksisen». Dette gjaldt også for de andre eksemplene, selv om studentene her opplagt ikke ble like sterkt omgitt av de fysiske omgivelsene de ellers vil komme til å kjenne som «praksissted». De var ikke i nærheten av å tenke at «dette er på ordentlig». Paradokset er at for å leve seg inn i en tilstand der man gjør og tenker «som om», må studentene pendle mellom ulike sinnstilstander. På den ene siden skal de være kyniske og nære i situasjonen, og på den andre siden skal de tenke vidt og fantasifullt om hva som kan skje «dersom jeg prøver dette». Dette mellomliggende og foreløpige sett av måter å forholde seg på er typisk for hvordan profesjonelle lærer i sitt yrke og utvikler ekspertise (Eraut, 2008), eller det som Markauskaite og Goodyear (2016) kaller å tilegne seg en epistemisk flyt, som når man kan veksle sømløst mellom ulike språk. Selv om simuleringenes manus eller skript kan være svært eksplisitt, er studentens årvåkenhet og kreativitet brakt i spill under noen intense øyeblikk med improvisasjon. Da er de avhengig av evnen til å tørre og holde ut i det situasjonen krever. På det viset blir det å balansere emosjonelle inntrykk og hente ut kognitive ressurser når spente situasjoner krever en løsning, en nøkkelferdighet (Roberts \& Greene, 2011). 
Kanskje er dette en optimal situasjon for å utvikle evnen til å koble de mange skjemaer og virksomhetsplott som trengs for å utvikle profesjonell kunnskap? Først skal studentene evne å gjøre raske analyser av situasjonen, så skanne dem mot alle kjente alternativer for handling, deretter velge det mest sannsynlig beste og til sist handle ut fra dette. Denne følgerekken bør bli så automatisert at den lar seg gjøre, og likevel gjøres så eksplisitt at en makter å gjenkalle og reflektere over prosessen. Det er ikke alle studenter som formår å koble gammel og ny kunnskap like lett, eller som forbereder seg adekvat for å møte situasjonene på en hensiktsmessig måte. I profesjonsstudier med krav til å være «skikket» er det viktig at den rette kombinasjonen av verdier, kunnskaper og holdninger utvikles i profesjonens etiske støpeskje. Simuleringer som er mindre krevende på dette punkt, kan tillate større grad av variasjon og distanse i rolletaking, men evne til å la seg trekke inn i dramaets flyt og forestillingsverden vil være en styrke for studenten. Vi mener dette viser at godt utført simulering øker kvaliteten i studiene.

\section{Simulering som brubygger mellom praksis og teori}

I innledningen spurte vi hvordan simuleringer og rollespill brukes i undervisningen i studier som jus, sykepleie og ledelses- og organisasjonsfag. Vi spurte også om på hvilke måter denne praksisen kunne tjene et formålom å bygge bruer mellom teoriundervisning og praksis i faget. De tre fagene løser utfordringen på ulike måter. Sykepleiestudiene bruker simuleringer for å øve ferdigheter i sammenhengende pleiepraksis og for å øve refleksjonskapasiteten når studentene er midt i en ordinær praksis i en institusjon. Organisasjons- og ledelsesfag bruker rollespill for å oppøve praktiske ferdigheter som å gjennomføre intervju med jobbsøkere og ansettelsesprosedyrer. Jusstudentene får øve seg i en rettsal med å prøve ut argumentasjon og andre prosedyrer som hører hjemme i en «ekte» sak ført for retten. Alle eksemplene demonstrerer at de oppfyller et krav som er omforent i forskningen om hvordan man skal heve kvaliteten i undervisning, nemlig at studentene må involveres mer i lærestoffet gjennom å interagere mer med lærere, medstudenter og lærestoff (Damsa et al., 2015). 
Den høyteknologiske konteksten man finner i et simuleringsstudio for sykepleieres utdanning, utfordrer studentene og får dem til å fokusere intenst og delta med både kropp og sinn. De blir observert og vurdert fortløpende av sine lærere, og deres prestasjoner er hele tiden med i en helhetlig vurdering. Balansen mellom spenning og årvåkenhet på den ene siden og ledigheten som tillater feil og frikoblet refleksjon på den andre siden er et følsomt og vanskelig skille å holde. Organisasjon- og ledelsesfagenes studenter var i det store og hele entusiastiske med hensyn til sitt rollespill, der skriptene var konsise og utfordrende nok til at de kunne leve seg inn i dem, og enkle nok til å følge som prosedyre. Jusstudentene går inn i sin rettssal med innlevelse i det dramaet som spilles ut, og med høye forventninger og kritiske tanker om forløpet. De opplevde unisont situasjonen som realistisk og en god prøve på den virkeligheten de ser for seg som praktiserende jurister. I alle tre eksemplene uttrykker studentene at de fikk øving i å treffe valg i pressede situasjoner. De kjente på at auditoriets komfortsone ble forlatt og at den dramatiske og uforutsigbare simuleringssituasjonen bød på helt andre og meningsfulle utfordringer. Det virker som at det å trene studentene til å møte risiko, i situasjonsbestemte utfordringer som krever avgjørelser og handlinger, og reflektere sammen med andre studenter og lærere som er eksperter i feltets teori, er gode bidrag til å korte ned avstanden - og bygge bro over gapet - mellom fagets teori og praksis.

\section{Referanser}

Bradley, P. (2006). The history of simulation on medical education and possible future directions. Medical Education, 40(3), 254-262. https://doi.org/10.1111/j.13652929.2006.02394.x

Colley, S. (2003). Nursing theory: Its importance to practice. Nursing Standard, $17(46), 33-37$.

Croxford, L. (2001). Global university education: Some cultural considerations. Higher Education in Europe, 26(1), 53-60.

Daly, Y. M. \& Higgins, N. (2011). The place and efficacy of simulations in legal education: A preliminary examination. AISHE-J, 3(2), 1-20.

Damsa, C., de Lange, T., Elken, M., Esterhazy, R., Fossland, T., Frølich, N., Hovdhaugen, E., Maassen, P., Nerland, M. B., Nordkvelle, Y. T., Stensaker, B., Tømte, C., Vabø, A., Wiers-Jenssen, J. \& Aamodt, P. O. (2015). Quality in 
Norwegian higher education: A review of research on aspects affecting student learning, NIFU report 2015:24. Oslo: Nordic Institute for Studies in Innovation, Research and Education.

Eraut, M. (2008). Learning from other people in the workplace. I K. Hall, P. Murphy \& J. Soler (Red.), Pedagogy and practice: Culture and identities (s. 40-57). Los Angeles: Sage og The Open University.

Gresalfi, M. \& Barab, S. (2011). Learning for a reason: Supporting forms of engagement by designing tasks and orchestrating environments. Theory into Practice, 50(4), 300-310.

Hopwood, N. (2017). Practice architectures of simulation pedagogy: From fidelity to transformation. I K. Mahon, S. Francisco, \& S. Kemmis (Red.), Exploring education and professional practice (s. 63-81). Singapore: Springer.

Jeffries, P. R. (2005). A framework for designing, implementing, and evaluating: Simulations used as teaching strategies in nursing. Nursing Education Perspectives, 26(2), 96-103.

Jørgensen, S., Skyttermoen, T. \& Syversen, T. L. (2011), I pose og sekk? Mot en prakademisk utdanning i organisasjons- og ledelsesfag - et studieutviklingsprosjekt som ble «kronet med gull». I G. Bjørke, O. Eikeland \& H. Jarning (Red.), Ny Praksis - ny kunnskap (s. 211-226). Oslo: ABM media.

Keskitalo, T. \& Ruokamo, H. (2016). Students' expectations and experiences of meaningful simulation-based medical education. Seminar.net. International Journal of Media, Technology and Lifelong Learning, 12(2), 110-123. Hentet fra http://seminar.net/104-frontpage/269-students-expectations-and-experiences-ofmeaningful-simulation-based-medical-education

Keys, B. \& Wolfe, J. (1990). The role of management game and simulation in education and research. Journal of Management, 16(2), 307-336.

Knoll, M. (1997). The project method: Its vocational education origin and international development. Journal of Industrial Teacher Education, 34(3), 59-80.

Kvernbekk, T. (1995). Om erfaringstyranni eller teorityranni: et vitenskapsteoretisk perspektiv på forholdet teori - praksis. Nordisk Pedagogik, 15(2), 88-96.

Markauskaite, L. \& Goodyear, P. (2016). Epistemic fluency and professional education. Dordrecht: Springer.

Nerland, M. \& Prøitz, T. S. (Red.) (2018). Pathways to quality in higher education: Case studies of educational practices in eight courses. NIFU report 2018:3. Oslo: Nordic Institute for Studies in Innovation, Research and Education. Hentet fra http://hdl.handle.net/11250/2478911

Norge Kirke-, utdannings- og forskningsdepartementet. (2001). Gjør din plikt - krev din rett: Kvalitetsreform av høyere utdanning: Tilrådning fra Kirke-, utdanningsog forskningsdepartementet av 9. mars 2001, godkjent i statsråd samme dag (Vol. Nr 27 (2000-2001), St.meld. ... (trykt utg.)). Oslo: Departementet. 
NOU 2015:3 Advokaten i samfunnet - Lov om advokater og andre som yter rettslig bistand.

Rall, M. \& Dieckmann, P. (2005). Safety culture and crisis resource management in airway management: General principles to enhance patient safety in critical airway situations. Best Pract Res Clin Anaesthesiol, 19(4), 539-557.

Reid-Searl, K., Eaton, A. Vieth, L. \& Happell, B. (2011). The educator inside the patient: Students' insights into the use of high fidelity silicone patient simulation. Journal of clinical nursing, 2o(19-20), 2752-276o. https://doi.org/10.1111/j.13652702.2011.03795.X

Roberts, D. \& Green, L. (2011). The theatre of high-fidelity simulation education. Nurse Education Today, 31(7), 694-698.

Rule, A. C. (2006). Editorial: The components of authentic learning. Journal of Authentic Learning, 3(1), 1-10.

Schaffer, D. W. (2012). Models of situated action: Computer games and the problem of transfer. I C. Steinkuehler, K. Squire \& S. Barab (Red.) Games, learning, and society: Learning and meaning in the digital age (s. 403-431). Cambridge: Cambridge University Press.

Shulman, L. (2002). Making differences. A table of learning. Change, 34(6), 36-44.

Skodvin, A. (2016). Engasjement i undervisningen. Uniped, 39(2), 102-117.

Tanner, C. A. (2004). The meaning of curriculum: Content to be covered or stories to be heard? Journal of Nursing Education, 43(1), 383-384.

Tansey, P. J. \& Unwin, D. (1969). Simulation and gaming in education. London: Methuen Educational.

Thomas, H. \& Wilson A. D. (2011). 'Physics envy', cognitive legitimacy or practical relevance: Dilemmas in the evolution of management research in the UK. British Journal of Management, 22(3), 443-456.

Tosterud, R. (2015a). Simulation used as a learning approach in nursing education. Students' experiences and validation of evaluation questionnaires. Doktoravhandling. Karlstad University Studies.

Tosterud, R. (2015b). Simulering - en hensiktsmessig læringsmetode? I T. Ødegården, S. Struksnes \& B. Hofmann (Red.), Pasientsimulering i helsefag: en praktisk innføring, 78-87, Oslo: Gyldendal Akademisk.

Universitets- og høgskolerådet. (2016). Kvalitet i praksisstudiene i helse- og sosialfaglig høyere utdanning: Praksisprosjektet. Oslo. 



\title{
KAPITTEL 7
}

\section{$\AA ̊$ skrive om hendelser fra egen praksis}

\section{Eli Skjeseth}

\section{Høgskolen i Innlandet}

\begin{abstract}
In this chapter, 60 reflection notes written by 20 students of continuing education for advisors in NAV are analysed. The research question is: What do the texts tell about the students' learning within the relationship between theory and practice? The intention of the chapter is to shed light on how the writing activity affects the students' thinking about their practice. The analysis follows two axes: on the one hand, the level of learning found in the texts is examined - how the learning is expressed in changes in behaviour/actions, and in thinking/assessment. The second axis shows the students' capacity for abstraction (theory formation) and for concretization based on theories. When these axes are put together, four categories emerge, which show different nuances in the relationship between theory and practice: 1) Synthesis (think 'up'), 2) Analysis (think 'down'), 3) Concepts promoted for practice, and 4) Testing of new methods.

The analysis shows that the students commute unproblematically between these categories. Practice is both a necessary breeding ground for learning and a benchmark for learning. Practice does not contradict theory. The writing activity helps to clarify theory and develop students' abstraction abilities. The teachers' responsibility is to formulate high quality assignment texts that bind together theory and practice and that would prompt the students to stretch their mental borders. The analysis categories developed in this chapter can help teachers successfully face this task.
\end{abstract}

Keywords: written assignments, reflection, abstraction, learning levels, counselling practices

\section{Introduksjon}

Det er rart at min ivrighet $i$ samtalene trenger en pause. De ble mer tydelig da jeg måtte skrive om min opplevelse av samtalen ... Nå merker jeg at selve samtalen har satt seg mer fast i meg enn vanlig.

Sitering av denne artikkelen: Skjeseth, E. (2020). Å skrive om hendelser fra egen praksis. I Y. T. Nordkvelle, L. Nyhus, A. Røisehagen og R. H. Røthe (Red.), Praksisnæer undervisning - i praksis og teori (Kap. 7, s. 121-140). Oslo: Cappelen Damm Akademisk. https://doi.org/10.23865/noasp.94.ch7.

Lisens: CC BY 4.o. 
Etter at han er gått fra kontoret kjenner jeg meg svoert utmattet og fysisk sliten, mer enn det jeg bruker å vare etter selv en krevende samtale. Det er mange tanker som kjemper om oppmerksomheten. Jeg skriver umiddelbart ned en logg fra samtalen. —Eva, NAV-veileder og student

I dette kapitlet analyseres 60 refleksjonsnotater skrevet av 20 studenter ved en videreutdanning for veiledere i NAV. Problemstillingen er: Hva forteller tekstene om studentenes loering i relasjonen mellom teori og praksis? Intensjonen med kapitlet er å vise studentenes læring med vekt på forholdet mellom deres praksis og deres abstraksjoner knyttet til denne praksisen. Analysen følger to akser. På den ene siden undersøkes læringsnivået som kommer fram i tekstene, hvordan læringen kommer til uttrykk i endringer i atferd/handlinger, og i tenkning/vurdering. Den andre aksen viser studentenes evne til abstraksjon (teoridannelse) og til konkretisering ut fra teorier. Når disse aksene blir satt sammen, kommer det fram fire kategorier som viser ulike nyanser i forholdet mellom teori og praksis:

1) syntese (tenke «opp»), 2) analyse (tenke «ned»), 3) begreper blir førende for praksis, og 4) utprøving av nye metoder.

Analysen viser at studentene pendler uproblematisk mellom disse kategoriene i sine tekster. Praksis er både en nødvendig grobunn for læring og en målestokk for læring. For studentene står ikke praksis i motsetning til teori, eller som noe fundamentalt annet enn teori. Skriveaktiviteten bidrar til å tydeliggjøre teori og utvikler studentenes abstraksjonsevner, samtidig som innholdet i tekstene er praksisnære. Undervisernes oppgave er å formulere oppgavetekster som binder sammen teori og praksis, og som gjør at studentene må strekke seg mentalt. Analysekategoriene som er utviklet i dette kapitlet, kan kanskje hjelpe underviserne i dette arbeidet.

\section{Bakgrunn}

Jeg er høgskolelektor i veiledning i et team bestående av sju kolleger ved Høgskolen i Innlandet. Våre studietilbud er videreutdanninger og masterprogrammer som søkes av voksne, erfarne studenter som i hovedsak jobber i offentlig og halvoffentlig tjenestesektor. De jobber med mennesker, 
og de har en praksis (praktisk erfaring) i forkant av studiene. Dermed har de mange knagger å henge det faglige innholdet i undervisningen på. De fleste tar studiene på deltid og har sitt arbeid pågående parallelt med studiene. De har oppmerksomhet på nåtid og på nær framtid: De kan dra rett tilbake i jobb med det de lærer i studiet og prøve det ut, for deretter å komme tilbake til studiesituasjonen med helt fersk praktisk erfaring. I mitt team er vi ydmykt oppmerksomme på at vi er "privilegerte» som undervisere i UH-sektoren. Praksisnærheten er til stede gjennom studentenes nærvær. Tilførselen av ferske fortellinger fra studentenes utprøvinger, fortellinger om suksess og fiasko (og alle nyansene imellom), er stor og dynamisk. Som undervisere lærer vi svært mye av våre studenter. Det er et godt utgangpunkt for en dialogisk undervisningspraksis hvor lærere og studenter har ekte toveiskommunikasjon gjennom studiet. Det som også har slått mine kolleger og meg, er at innholdet i tekster fra studentene er som en skattkiste av lite utforsket empirisk materiale. Å intervjue studenter gir empiri, men kan også være litt som «å gå over bekken etter vann», i forhold til å studere selve tekstene som studentene har skrevet. Tekstene utgjør empirisk materiale både om praksisfeltet i seg selv og om studentenes læring. Det er det siste jeg har undersøkt i den studien som presenteres her.

I dette kapitlet vil jeg gjøre rede for en analyse av studenters tekster innlevert som såkalte arbeidskrav fra studiet «Veiledning i arbeids- og velferdsforvaltningen». Jeg har avgrenset problemstillingen til: Hva forteller tekstene om studentenes loering $i$ relasjonen mellom teori og praksis? Først vil jeg beskrive kort veiledningsfaget, studentene, studiet og arbeidskravene. Deretter vil jeg presentere det teoretiske grunnlaget, analysekategoriene og hvordan jeg har gjennomført analysen. Videre vil jeg trekke fram og tolke funn i materialet. I det konkluderende avsnittet har jeg inkludert noen ideer og anbefalinger for andre som bruker skriftlige refleksjonsoppgaver i undervisningen.

\section{Hva slags fag er veiledning?}

Veiledning er en aktivitet som de fleste mennesker - leg og lærd - deltar i med liv og lyst. Vi er vekselvis veisøkere og veiledere. Veiledning som fag 
spenner bredt over felter av menneskelig aktivitet, former og innhold. Veiledning i en profesjonell ramme kan derfor være vanskelig å avgrense mot for eksempel instruksjon, rådgiving og terapi. Veiledningslitteraturen byr på et stort mangfold av metoder som kan være både overlappende og motstridende. Det er likevel stor enighet om at god veiledning kjennetegnes av en dialogisk form og en respektfull holdning til veisøker (Eide, Aasland, Grelland \& Kristiansen, 2008; Seikkula \& Arnkil, 2013; Tveiten, 2019).

En utdanning i veiledning er i utgangspunktet tverrfaglig og tverrvitenskapelig, idet en søker å integrere ulike fags begreper og metoder i en felles kjerne (Bhaskar \& Danermark, 2006; Nenseth, Thaulow, Vogt \& Orderud, 2010). Det er verdt å merke seg at veiledning inngår i en felles faglig kjerne av kompetansemål for alle 19 helse- og sosialfaglige høyere utdanninger, ifølge forskrift til Universitets- og høyskoleloven (Kunnskapsdepartementet, 2017).

\section{Studentene og studiet}

Videreutdanning i veiledning i NAV retter seg mot alle ansatte i NAV som har en reell veiledingspraksis overfor brukere eller kolleger. Stillingsbetegnelsen NAV-veileder er relativt ny og erstatter betegnelsen saksbehandler. Intensjonen med endringen var å synliggjøre mennesker framfor saker, samt å løfte fram veiledning som aktivitet og fag (Andreassen \& Aars, 2015).

Studiet gir 30 studiepoeng og er lagt opp med seks todagers samlinger der teoristoff gjennomgås, deltakerne gjennomfører strukturerte øvelser og utveksler erfaringer. De møter også gjesteforelesere som representerer viktige samarbeidsaktører i studentenes praksis. Arbeidsinkludering er et gjennomgående tema.

Studentene har praksisoppgaver (arbeidskrav) mellom samlingene. De leverer tekster der de svarer på en oppgave gitt av fagansvarlig ved studiet. Alle får en individuell, skriftlig tilbakemelding fra sin veileder. Tekstene blir videre delt og drøftet i mindre grupper på samlingene. De danner grunnlaget for caser som brukes for å anskueliggjøre viktige fenomener og kompetanser i veiledning. Dette gjøres både ved å trekke 
ut studentenes egne caser i plenum og knytte dem til den teorien som presenteres, og som utgangspunkt for kollegaveiledningsøkter i mindre grupper. Spørsmålene stilles av studentene selv: Hvordan tenker jeg om denne casen? Er det andre måter å tenke på? Hva gjorde jeg, og hva fungerte (ikke)? Hva kan gjøres annerledes? Hva kommer jeg til å gjøre i oppfølgingen av denne brukeren?

Hovedmålene med studiet er at deltakerne skal

- bli tryggere, tydelige og fleksible i sin veilederrolle

- engasjere seg i dialogpreget kommunikasjon med brukere og deres nettverk

- $ø k e$ ressursorientering (på bekostning av problemorientering) i seg selv og hos bruker

- øke samarbeid og kontakt med arbeidslivet

- arbeide aktivt for å fremme et inkluderende arbeidsliv

Hovedmålene er utdypet og presisert i 12 utbyttebeskrivelser i tråd med kvalifikasjonsrammeverket for høyere utdanning (kunnskaper, ferdigheter og generell kompetanse). I oppstarten av studiet gjennomfører vi en aktivitet som får fram studentenes egne intensjoner med å ta studiet. De blir bedt om å prioritere læringsutbyttebeskrivelsene (slik de er formulert i studieplanen), begrunne sine prioriteringer overfor hverandre, samt omskrive dem med egne ord. Vi registrerer at et stort flertall prioriterer ferdighetsmålene. Dette er ikke overraskende ut fra NAV-veiledernes hverdag og rammevilkår. De står i vedvarende «handlingstvang» overfor et stort antall brukere, og bærer forvaltningen av en ambisiøs velferdsstat på sine skuldre (Andreassen \& Aars, 2015; Hansen, Lundberg \& Syltevik, 2013; Ose, 2016). Studentene tenker på seg selv som praktikere, og de ønsker å dyktiggjøre seg i veilederjobben på en konkret måte. Mange sier at de er uvante med å lese, skrive og snakke om teori. Spørsmål om forholdet mellom teori og praksis er svært relevant for denne studentgruppen. Studentenes praksis er både en slags grobunn for læring og en målestokk for læring. Grobunn er brukt som metafor fordi uten praksisen ville ikke de teoretiske begrepene hatt noe konkret å feste seg til og utvikle seg fra i veilederens tankeverden. 
Framgangsmåte for analysen av tekstene:

For studieåret 2016-17 har jeg innhentet tillatelse fra 20 studenter om å bruke deres skriftlige arbeider til forskning i egen undervisningspraksis. Prosjektet bruker ikke personopplysninger, og tekstene er fullstendig anonymisert. Jeg har valgt tre praksisoppgaver:

1. Skriv en refleksjonslogg på 2-3 sider der du beskriver en veiledningssamtale med bruker.

2. Skriv en refleksjonslogg på 3-4 sider der du forteller om en samtale med en bruker, strukturert etter en mal på 5 punkter, inklusive referanser til litteratur.

3. Skriv en rapport på 6-8 sider fra et avgrenset «miniprosjekt», der oppgaven er: Ta initiativ overfor arbeidsgivere til en aktivitet med en tydelig intensjon om resultater (konkret for en eller flere brukere, eller som nettverksbyggende aktivitet).

Oppgavene skal leveres mellom samlingene, den første cirka en måned etter studiestart og den siste rundt en måned før eksamen. Det er en bevisst faglig progresjon fra oppgave 1 til 3 . Vi starter med en ren praksisfortelling, for deretter å øke kravene til å tydeliggjøre koblinger mellom egen praksis og teori, til å strukturere og fordype teksten, samt at kompleksiteten i selve praksisen øker.

Antakelsen om at skriving styrker læringen, ligger til grunn for valget av arbeidskrav. Skriving som læringsaktivitet blir flittig brukt i høyere utdanning. Generelle læringseffekter av skriveaktiviteter er undersøkt av flere (Dysthe, Hoel \& Hertzberg, 2010; Johansen, 2003; Säljö, 2006) og viser at skriveaktiviteten skjerper og utdyper studentenes tenkning. Det er gjort studier av refleksjonslogger ved andre læresteder, men da med vekt på subjektive vurderinger av studentenes utfordringer med selve det å skrive (Jonsmoen \& Greek, 2012).

Jeg har ikke spurt studentene om hva de lærer spesifikt av selve skriveaktiviteten, heller ikke hvordan de lærer. Tekstene deres er for øvrig skrevet uavhengig av analysen jeg har gjort som grunnlag for dette kapitlet. De er skrevet som svar på en oppgave i studiet, gitt med den intensjon at studentene skal lære mer om egen praksis ved å beskrive den og reflektere over den i lys av teori på fagfeltet. 
I prosessen med å finne svar på problemstillingen: Hva forteller tekstene om studentenes loering i relasjonen mellom teori og praksis? har jeg vekslet mellom gjentatte lesninger av tekstene og det å utvikle en modell av kategorier som gjenspeiler læringen i studiet. Jeg konstruerte etter hvert en modell i form av en tabell som sammenstiller to akser av variabler om ulike aspekter av læring (se tabell 1). Modellen kobler læringsteori med min nysgjerrighet på å forstå hva som skjer i studentene nettopp i dette studiet. Tekstene er lest med oppmerksomhet på hvor og hvordan de ulike kategoriene framkommer. Utdrag fra tekstene ble kodet med den kategorien som jeg fant mest framtredende. Kodingen dannet grunnlaget for å velge utdrag fra tekstene til presentasjon og fortolkning. Prosessen kan karakteriseres som abduktiv, i og med at jeg setter sammen kjente teoretiske elementer på en ny måte og fortolker empirien i et nytt perspektiv (Danermark, Ekstrom, Jacobsen \& Karlsson, 2003).

\section{Teoretisk grunnlag for læring og forandring}

Som pedagoger og undervisere har vi ansvar for rammer der mennesker skal lære, og må derfor ha et reflektert forhold til hva læring er. Jeg slutter meg til Säljö (2006), som understreker at sammenblandingen av undervisning og læring er et stort begrepsmessig problem i den pedagogiske diskurs. Han hevder at læring er et mye bredere begrep enn undervisning, et «uendelig og uavsluttet eventyr» for mennesker. Undervisning, veiledning, livserfaring og arbeidserfaring kan bidra til læring, men er forskjellig fra selve læringen.

Jeg tilhører en yrkespedagogisk tradisjon med et læringssyn som vektlegger læringens situerte karakter (Eikeland, 2015; Elmholdt, 2001; Lave \& Wenger, 2003). Jeg legger til grunn at læring er en form for forandring som foregår i det enkelte menneske, og at læring er situert i sosiale praksiser (Säljö, 2006).

Moxnes (2000) påpeker at mange hverdagslige ord og begreper som brukes om læring, inneholder et element av forandring. Derfor mener han at en tradisjonell definisjon av læring som forandringer av atferd, holdninger, tanker eller følelser fortsatt er gyldig. Nyere nevrovitenskap 
peker imidlertid på at et tradisjonelt skille mellom tanker og følelser som to grunnleggende ulike mentale prosesser ikke stemmer (Damasio, 2002; Siegel, 2012; Wiben Jensen \& Skov, 2007). En mer integrert forståelse av forholdet mellom følelser og kognisjon er at følelsene informerer selvet på en helt fundamental måte og må regnes som en integrert del av kognisjonen. Konsekvensen av en slik forståelse blir etter min oppfatning at undervisningen bør stimulere følelser og øke den lærendes bevissthet på hvordan egne følelser oppstår, endrer seg og påvirker atferd og dømmekraft. Som følge av forskningen til Damasio med flere, referert til over, mener jeg at begrepet tanker inkluderer følelser, slik at også læringsbegrepet som følge av dette kan sammenfattes til endringer av tanker og handlinger.

Bateson (1972) introduserte en forståelse av læring på ulike nivåer, en oppfatning som deles av en rekke pedagogiske teoretikere. Jeg gjorde meg kjent med Batesons læringsnivår og brukte dem som analysegrunnlag i en komparativ studie av arbeidsplassbasert læring på fem arbeidsplasser (Skjeseth, 2004). Nyhus (2011) har sammenlignet Batesons nivår med fem andre velkjente teoretikeres lærings- og/eller refleksjonsbegreper og sammenfattet dem i en metamodell for læring på tre nivåer: I. ordens læring som forandring i atferd/handlinger, II. ordens læring som forandring i intensjoner og III. ordens læring som forandring i presupposisjoner. Presupposisjoner brukes her som samlebetegnelse for verdier, forforståelse, referanserammer, underforståtte antagelser med mer.

Læring som forandring inkluderer små forandringer, som forskyvninger, justeringer og bevisstgjøring. En forskyvning av oppmerksomhet kan resultere i økt sanseskarphet overfor signaler og stemningsskifter i kommunikasjonen mellom veileder og veisøker. Forandring i intensjoner kan handle om hvilke intensjoner som kommer i forgrunnen og blir prioritert av veileder på bekostning av andre. Forandring av presupposisjoner kan handle om justert selvoppfatning, økt trygghet i skjønnsutøvelse, økt bevissthet om det tankegrunnlaget som ligger til grunn for egen praksis. Begrepet presupposisjon sammenfatter dette fint; det er noe som må ligge til grunn (sub) på forhånd (pre) og posisjonerer aktørens tanker. 


\section{Om teori og praksis}

Vi har i denne boken lagt til grunn at praksis er det livet vi lever, og virkeligheten. Grete Halvorsen skriver i kapittel 2 at «praksis beskriver menneskets eksistensielle virkelighet og dets handlinger i denne virkeligheten». Jeg vil i det følgende beskrive hvordan NAV-veilederens eksistensielle virkelighet og handlinger i denne virkeligheten fortoner seg. Arbeidet består i stor grad av kommunikasjon med brukere, kolleger og samarbeidspartnere. En NAV-veileder lever sitt arbeidsliv i kontakt med NAV-brukeren, men på «innsiden av skranken» (metaforisk). På den andre siden av skranken lever og virker brukeren i sin praksis. Brukerens behov for å «nærme seg skranken» og kommunisere over den handler om eksistensielle forhold: økonomi, helse, arbeid, nettverk. NAV skal være et finmasket sosialt sikkerhetsnett i velferdssamfunnet. Veiledere forteller om brukere som er «utskrevet» fra helsevesenet fordi de ikke møter opp til timene, mens NAV-kontakten trenger de for å leve. Vi kan se for oss en skala av marginalisering og utenforskap, fra det midlertidige og relativt udramatiske som permittering, pensjonering, fødsler og sykefravær til brukere som står i fare for å ta sitt eget liv. Veilederne jobber med hvert enkelt individs behov i den situasjonen de står i. Fra dette omdreiningspunktet kreves ofte omfattende nettverksarbeid som støtter opp under arbeidsinkluderings- og tilfriskningsprosesser.

Danermark et al. (2003) hevder at det finnes en utbredt forestilling om at vitenskapelig kunnskap skal utvikles av forskere som i sin tur leverer den «ferdig pakket» til praktikerne. Hvis den viser seg å være vanskelig å ta i bruk, for å være feilaktig, eller ute av kontakt med den praktiske, konkrete virkeligheten. Ofte klandres akademisk kunnskap for å være for abstrakt. I motsetning til dette synspunktet hevder de at

Det teoretiske är inget annat än de begrepp vi har om verkligheten - oavsett om det er forskare eller praktikere som har dem; och det abstrakta utgör et utdrag ur verkligheten, et utdrag bestående av det väsentliga, det essensiella eller kärnan i ett fenomen. (Danermark et al., 2003, s. 318)

Jeg slutter meg til dette synet. Kompetanseutvikling må omfatte både bevisstgjøring av egne abstraksjoner som f.eks. egen yrkesteori (Lauvås \& Handal, 2014) og tilgang til samfunnets oppsamlede, beste kunnskap på 
et felt. Den etterspurte og viktige ferdighetstreningen blir mer bærekraftig når den hviler på teoretiske begrunnelser som i sin tur er gjenstand for læring. Hvis studentene oppøver sin evne til å identifisere og gjenkjenne kjernen i sin veiledning, har vi kommet langt i retning av målet om tryggere, tydeligere og mer fleksible yrkesutøvere.

Fra systemteorien (Watzlawick, 1996) henter jeg betegnelsen logiske nivåer som en felles betegnelse på prosesser som beveger seg mellom konkretisering og abstraksjon. Det går begge veger; å abstrahere gir teoridannelse, å konkretisere gir praksisanvendelse.

\section{Analysekategorier}

I tråd med dette teorigrunnlaget har jeg valgt å analysere studentenes tekster langs to akser:

1. Hvilke forandringer i tanker og atferd/handlinger kommer til syne i tekstene? For enkelthets skyld velger jeg å ikke skille mellom II. ordens og III. ordens læring, men slår sammen intensjoner og presupposisjoner i verbet tenke. Dette utgjør de to kategoriene i den horisontale aksen.

2. Hva forteller tekstene om studentenes bevegelser fra det konkrete til det abstrakte, og omvendt? Studentenes tekster kan gjenspeile to retninger mht. de logiske nivåene: abstraksjon («opp») og konkretisering («ned»), som utgjør de to kategoriene i den vertikale aksen. Bevegelsene kalles også henholdsvis induktiv og deduktiv i vitenskapsteori (Danermark et al., 2003). Bruken av metaforene «opp» og «ned» er hentet fra Lakoff og Johnsens analyse av primærmetaforer i språket. «Opp» og «ned» stemmer overens med våre intuitive, kroppslige assosiasjoner, altså at abstraksjon ligger «over» den «jordnære» praksisen «på golvet» (Lakoff \& Johnson, 1999).

Når disse aksene blir satt sammen, kommer det fram fire kategorier som viser ulike nyanser i forholdet mellom teori og praksis: 1) syntese (tenke «opp»), 2) analyse (tenke «ned»), 3) begreper blir førende for praksis, og 4) utprøving av nye metoder. Disse er visualisert i tabell 1. 
Tabell 1. Analysekategorier sammenstilt.

\begin{tabular}{|l|l|l|}
\hline $\begin{array}{l}\text { Forandring } \\
\text { Logiske nivåer }\end{array}$ & $\begin{array}{l}\text { Tenke - } \\
\text { ii. og iii. ordens læring }\end{array}$ & $\begin{array}{l}\text { Gjøre - } \\
\text { i. ordens læring }\end{array}$ \\
\hline $\begin{array}{l}\text { Abstraksjon } \\
\text { «opp» }\end{array}$ & $\begin{array}{l}\text { 1) Danne, syntetisere og justere } \\
\text { generaliserte begreper (teori). F.eks. } \\
\text { endre/justere egne presupposisjoner } \\
\text { Syntese - tenke «opp» }\end{array}$ & $\begin{array}{l}\text { 3) Begreper (teori) fra studiets } \\
\text { faglige innhold fungerer førende for } \\
\text { praksis (handlinger og aktiviteter), } \\
\text { gjennom bevisst oppmerksomhet. }\end{array}$ \\
\hline $\begin{array}{l}\text { Konkretisering } \\
\text { «ned» }\end{array}$ & $\begin{array}{l}\text { 2) Analysere hendelser og } \\
\text { fenomener i egen praksis og kjenne } \\
\text { igjen teoretiske begreper. «Dette er } \\
\text { et eksempel på teorien om ..... } \\
\text { Analyse - tenke «ned» }\end{array}$ & $\begin{array}{l}\text { 4) Utprøving av nye metoder, } \\
\text { inspirert av tilganger i studiet }\end{array}$ \\
\hline
\end{tabular}

De fire kategoriene er tenkt slik:

1. Syntese - tenke «opp» - innebærer en tankeprosess der den lærende går fra det partikulære til det generelle. På bakgrunn av konkrete hendelser og opplevelser (praksis) der teori ikke nødvendigvis er bevisst, gjør den lærende i ettertid justeringer/endringer i egne presupposisjoner eller i sine intensjoner.

2. Analyse - tenke «ned» - å gjenkjenne fenomener i sin praksis som konkrete eksempler der begreper/teori kommer til uttrykk. Gjenkjennelse trenger ikke å føre til direkte forandringer i tenkningen, men gir trening i å tolke og forstå den konkrete virkeligheten, der begrepene er tankeredskaper for en slik forståelse.

3. Bevegelsen går også her i utgangspunktet fra det konkrete til generelle, gjennom at faglige begreper er løftet, forstått og akseptert av den lærende. I denne kategorien inkluderes ny handling som er styrt av en bevisst oppmerksomhet. Kategorien inkluderer altså tanke og handling, mens det er intensjonal, bevisst handling jeg leter etter i studentenes tekster.

4. Utprøvinger av nye metoder. Bevegelsen er deduktiv, gjennom at oppskrifter for handling blir prøvd ut, uten at det essensielle ved dem nødvendigvis er tydeliggjort for eller forstått av den lærende.

Det kan (med rette) innvendes mot disse resonnementene at læring er helhetlig, at alle kategorier er virksomme i individet samtidig, og at den 
lærende ikke opplever sin prosess som oppstykket i slike delprosesser. Men forskning innebærer analyse. Det betyr å splitte opp en helhet for å undersøke og lære mer om delene, selv om det i ontologisk forstand ikke lar seg dele.

\section{Hva forteller studentens tekster?}

De 60 tekstene inneholder beskrivelser - til dels ganske detaljerte - av forskjellige hendelser fra praksis. Det første som slår en, er alvorligheten i selve innholdet og vanskelighetsgraden av veiledningsoppgavene. Noen skiller ut egne tanker og ettertanker fra observasjonene, mens andre kommenterer fortløpende. Dybden og omfanget av refleksjonene varierer ganske mye. Fordelingen av innhold i de fire kategoriene er skjev, med flest eksempler på bevisst oppmerksomhet, minst på utprøving av nye metoder. Dette er ikke overraskende, og samsvarer med hvordan undervisningen er lagt opp. Vi legger vekt på å utvikle kompetanse som må ligge til grunn for at et bredt spekter av metoder skal fungere, framfor bindinger til spesifikke, navngitte «metodepakker».

I det følgende gir jeg eksempler på temaer fra de fire kategoriene i form av sitater fra tekstene sammen med mine tolkninger av hva det forteller om studentenes læring. Uthevet skrift i sitatene er gjort av meg for å framheve faglige begreper som studentene bruker

\section{Syntese - tenke «opp»:}

Jeg har ikke funnet eksempler på nyskapende teoridannelse i tekstene. Det studentene forteller om i form av synteser, stemmer overens med velkjent teori innen veiledning. Det er imidlertid mange eksempler på at studentene revurderer sine praksisteorier (Lauvås \& Handal, 2014) og endrer sine presupposisjoner. Et tema som går igjen, er vurderinger av makt og påvirkning i relasjoner:

A: Jeg har en jobb der jeg sitter med makt, og NN er i en situasjon der hun vil vere lett å påvirke. Dette er viktig at jeg tenker over i alle mine samtaler.

B: $\quad$ Jeg tror jeg skapte motstand ved å si hva han burde gjøre i forhold til hva han hadde gjort ... at han burde presse seg hardere og gjøre mer øvelser ... 
jeg har tenkt mye på denne samtalen, og jeg har bestemt meg for å be om unnskyldning for det som skjedde, når han kommer til ny avtale om en uke.

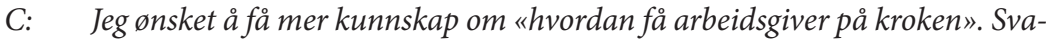
ret jeg sitter med nå, vil jeg sammenfatte med få ord: Jeg må opparbeide meg en god relasjon til og informasjon om arbeidsgiver og aktuell kandidat.

Anvendelsen av begrepet makt i As tekst er en personlig erkjennelse i en konkret samtale, som hun deretter generaliserer til bevissthet $\mathrm{i}$ «alle samtaler». B forteller om en brukers reaksjon på sterkt normativ rådgiving, som igjen gir B selvransakende reaksjoner i ettertid. C er selvransakende i sitt forhold til arbeidsgiverne, der hun utvikler sin tenkning fra å ville få arbeidsgiver "på kroken», til å innse at relasjonsbyggingen må være noe mer enn å bruke salgstricks.

I tekstene finnes det mange eksempler på endringer i presupposisjoner om seg selv, som denne:

D: $\quad$ Avslutningsvis tenker jeg at jeg ikke trenger å vore så redd for ikke å strekke til. Når jeg gjør noe feil, håper jeg å kunne se på det som en mulighet for loering.

Sitatene A-D ovenfor forteller at studentene generaliserer sin erfaring fra de konkrete situasjonene til noe som er gyldig i alle situasjoner, og som dermed har potensial for å endre praksis. Hvis jeg som forsker et øyeblikk tillater meg å spekulere, er det nesten så jeg kan høre studentens indre dialog: «i det kommende møte må jeg må tenke på at jeg har makt», «neste gang jeg gjør noe feil, vil jeg ha oppmerksomhet på læring», «nå må jeg unngå impulsen til gi moraliserende råd». Det er grunn til å tro at den refleksive distansen som selve skrivingen skaper, vil forsterke og befeste læringen (Dysthe et al., 2010). Skrivingen tydeliggjør den mentale bevegelsen fra det konkrete logiske nivået (enkeltsamtalen) til et overordnet logisk nivå (alle samtaler).

\section{Analyse - tenke «ned»:}

I denne kategorien finner jeg eksempler på gjenkjenning av faglige begreper. Her kommer det ikke eksplisitt fram at studenten kommer til å endre noe (tanker, praksis), men gjenkjennelsen er et tegn på at de teoretiske 
begrepene er forstått som noe essensielt, som en kjerne. I det følgende sitatet kommer gjenkjennelsen fram når studentene leser sine egne notater.

E: $\quad$ Når jeg leser mine notater fra samtalen, framstår anerkjennelse som sentralt ... Jeg sitter likevel igjen med en følelse av at det foregikk mer enn jeg kunne sette ord på. Jeg finner en mulig forklaring mot slutten av Grete Halvorsens artikkel: «En anerkjennende holdning inneborer altså en villet oppmerksomhet mot den andres uttrykk og eget inntrykk - som vorende».

E knytter sin case-beskrivelse til litteratur om anerkjennelse, og forsetter sine refleksjoner i en interessant kobling mellom teori og egen praksis. At det foregikk mer enn hun kunne sette ord på når hun skrev notatene, blir faktisk satt ord på i denne teksten.

De neste eksemplene viser variasjoner i følelsestilstander hos deltakerne i samtaler, fra indre uro til åpen konflikt. Veiledning i et uforutsigbart emosjonelt minefelt krever en balansegang mellom det private, det personlige og det profesjonelle (Halvorsen, 2011). Veilederne inngår i systemiske relasjoner med aktørene (Ulleberg \& Jensen, 2017) og blir selvsagt påvirket av følelsestrykket i samtaler og møter. I tekstene får studentene distanse til følelsene. De faglige begrepene som er tematisert i studiet og som studentene bruker i sin tekster, er uthevet i de følgende sitatene:

F: $\quad$ Det er mye frustrasjon som har bygd seg opp fra flere kanter, og det virker mer som at hjelpeapparatet hadde rottet seg sammen om en som skriker om hjelp, men som ikke klarer å ta imot hjelpen. Konflikten mellom brukeren og psykiateren fikk altfor mye tid i samtalen og ødela hele dynamikken. Tryggheten og tilliten forsvant, og brukeren lukket igjen.

G: $\quad$ Det jeg tenkte på da var at jeg var litt mye åpen om meg selv og gav for mye av meg selv. Det gjorde at jeg følte en indre uro, hadde jeg vort for personlig? Samtidig tenkte jeg at når man jobber med mennesker må man gi litt av seg selv uten at man utleverer seg. Hun sa hun hadde fätt mange nye tanker og ble inspirert til å komme seg videre. Det overbeviste meg at den mellommenneskelige relasjonen kan ha betydning for arbeidet jeg er satt til å gjøre i NAV som veileder.

$H: \quad V i$ er mennesker og der det er mennesker kan ting skje som vi ikke forutser til enhver tid. Jeg lot han snakke ut når jeg forstod han trengte «å tømme 
seg». Jeg bestemte meg for å bare la han prate og tømme seg. Jeg var stille lenge. Det som skjedde da, var at han nesten begynte å gråte. Han innrømmet at han har et alkoholproblem, og når han hadde penger til disposisjon var det lett å drikke dem bort. Dette var nye opplysninger for meg.

Veileder og bruker er avhengig av andre aktører i sitt nettverk, både det private og det profesjonelle. Veileder $\mathrm{F}$ er vitne til en skadelig lukking $\mathrm{i}$ en samtale med flere aktører. F beskriver fra sin posisjon at velment hjelp fra en annen profesjon ikke blir tatt imot når den personen som saken gjelder, er redd og mistenksom. Fs analyse er at oppmerksomheten på selve konflikten rett og slett fikk for stor plass i selve møtet. F bruker en sterk metafor for hjelpeapparatet sett fra brukers perspektiv: De rotter seg sammen. Fs tekst er en eksemplifisering av avhengigheter og utfordringer i tverrfaglig samarbeid, og betydningen av å arbeide for å finne et felles faglig grunnlag (Bhaskar \& Danermark, 2006). Videre er det en gjenkjenning av hva som skjer når et av grunnprinsippene i dialogisk praksis (Seikkula \& Arnkil, 2013) ikke blir praktisert; nemlig å ikke snakke om brukeren bak brukerens rygg.

Åpenhet er også tema for veileder G og H. G diskuterer og problematiserer sin egen åpenhet, og konkluderer med at den ikke er farlig, men betydningsfull for sin praksis. $\mathrm{H}$ forteller en sterk historie om effekten av stillhet som virkemiddel i veiledning, der en uventet åpenhet oppstår, som igjen utløste en ny vending i relasjonen mellom veileder og bruker, og trolig mer treffsikker bistand framover.

Sitatene fra E, F, G og H er alle eksempler på studenter som gjenkjenner faglige begreper i sin praksis, både fra et teoretisk og et metodisk veiledingsfaglig perspektiv. Å forstå hva som skjer mens det skjer, kan være vanskelig. Selve skrivingen øker analysekapasiteten til å forstå de essensielle mekanismene, for eksempel åpenhet/lukkethet.

\section{Begreper blir førende for praksis}

I denne kategorien har jeg valgt ut sitater som forteller hvordan begreper fra studiets faglige innhold fungerer førende for praksis, altså for studentenes handlinger og aktiviteter, gjennom bevisst oppmerksomhet. Til forskjell fra forrige kategori, som omhandlet ren gjenkjennelse, har disse sitatene en helt direkte praksisrettet dimensjon. Studentene har 
intensjoner for sin egen atferd som de setter ut i livet med en gang. Selve begrepet intensjoner finner vi igjen som en abstraksjon (altså et teoretisk begrep) i det faglige innholdet i studiet.

I: $\quad$ Min intensjon endres til å forsøke å forstå bruker og hva som er viktig for han. Dette vurderer jeg som en nøkkel til framgang i samtalen. Jeg forsøkte å mobilisere all min kraft for å få dette til. Jeg forsøkte å lytte meg inn i det bruker fortalte, og visuelt fikk jeg i mitt indre opp et bilde av meg selv hvor jeg hadde en åpning inn i kroppen. Det var litt underlig, og det har jeg aldri opplevd før. Jeg opplevde det var svoert viktige og alvorlige ting som berørte meg, faktisk på liv og død.

I løpet av denne samtalen får veileder I en intuisjon av at innholdet i samtalen med bruker var viktigere og alvorligere enn hun hadde trodd. Derfor endrer hun intensjonen med samtalen underveis, og hennes bevisste anstrengelse for å benytte sin lytteferdighet gir henne en eksistensiell, kroppslig opplevelse.

J: $\quad$ Jeg valgte underveis å ikke stille så mye spørsmål til legen som jeg ellers gjør, da legens måte å kommunisere på førte til at hun (bruker) gråt mer.... I dette møtet var jeg bevisst både på atferd, rammer og intensjoner, og klarte derfor å snu fokus slik at min bruker kunne se det positive på arbeidsstedet, og dermed få fortgang i prosessen mot forandring - gjenoppta arbeidet var målet. Dette vil jeg bruke framover som veileder og møteleder - og som kollega.

Veileder J håndterer en følelsesladd samtale med flere parter «på strak arm» ved hjelp av begrepene intensjoner, rammer og atferd. Rammen for møtet er et dialogmøte som ledd i en sykefraværsoppfølging der den sykmeldte, fastlegen, arbeidsgiver og NAV-veileder deltar. Denne flerstemmigheten kan være uforutsigbar (Seikkula \& Arnkil, 2013). Veileder J observerer sammenhengen mellom legens kommunikasjon og brukers følelser. Js intensjon ble å snu oppmerksomheten mot målet, og det må gjøres med fintfølelse. Hun tar ledelse ved å rett og slett å begrense legens «taletid» ved å unnlate å henvende seg til legen med spørsmål. I dialogmøter har NAV-veilederne rollen som koordinator og møteleder, samtidig som de vanligvis har lavere status enn leger og arbeidsgivere. Det gjør 
Js praksisfortelling ekstra interessant, fordi hun med relativt enkle kommunikative virkemidler som hun selv er klar over, leder den sykmeldte og de andre i en konstruktiv retning.

\section{Utprøving av nye metoder}

I denne kategorien har jeg søkt etter eksempler på konkretiseringer av fagstoffet og praksisen i form av metoder, oppskrifter og verktøy.

K. Jeg vet at jeg liker å bruke samtaleverktøyene som åpne spørsmål, stillhet og oppsummering i samtalene mine. Jeg synes det er virkningsfullt og at jeg på denne måten oppnår mye mer innhold $i$ samtalen med bruker. ... Merker at jeg underveis $i$ samtalen kjenner ekstra etter hvilke tanker jeg gjør meg om hans situasjon på en helt annen måte enn jeg gjorde tidligere. Tror dette er første gang underveis $i$ en samtale at jeg virkelig reflekterte over hva jeg følte og hvordan jeg reagerte på svarene hans. Dette er ikke noe jeg har hatt fokus på tidligere.

Studenten har altså tidligere brukt «verktøy» som regnes som grunnleggende ferdigheter i veiledningsarbeid (Tveiten, 2019; Ulleberg \& Jensen, 2017), men oppdager en ny dimensjon gjennom å «kjenne etter hvilke tanker» hun gjør seg om hans situasjon. Dette sitatet forteller at verktøy kan brukes på flere nivåer. Begrepet verktøy gir assosiasjoner til instrumenter og en teknisk, overflatisk bruk. Hos denne studenten blir verktøyene en inngangsport til dypere innsikt og økt tilgang til sin egen indre dialog. I neste omgang kan denne tilgangen lede til økt kontakt og tillit mellom bruker og veileder, og kanskje til mer relevante forslag om hva bruker kan gjøre i sin situasjon.

\section{Konklusjoner og anbefalinger}

Hva forteller tekstene om studentenes loering i relasjonen mellom teori og praksis?

Jeg har i denne studien brukt fire kategorier for å undersøke studentenes skriftlige refleksjoner om sin læring: 1) abstraksjon som endrer tenkningen, 2) abstrakte begreper som blir førende for praksis, 3) analyse av egen praksis og 4) utprøving av nye metoder. 
Analysen viser at praksis er grobunn for læringen i den forstand at studentene starter sin mentale bearbeiding av veiledingsfaget gjennom å beskrive konkrete hendelser der de har vært utøvende veiledere overfor høyst reelle brukere. Studentene har «mengdetrening» i veiledning i NAV, og det som gror opp fra denne praksisen i studiet, er en utvidelse av «tankerommet» $i$ form av bevisstgjøring. Utvidelsen skjer både gjennom konkretisering og abstraksjon. Studentene gir konkrete eksempler på teoretiske begreper som er presentert og diskutert på samlinger og i studiets faglitteratur, og de sammenfatter sin erfaring i begreper som klargjør for dem det essensielle i praksisen.

At praksis også er målestokk for læringen, viser seg gjennom de faktiske endringene i atferd som tekstene forteller om. Det er mange eksempler på at veilederne forandrer sin praksis, gjerne i form av justeringer, og der teori fungerer som ledetråder i forandringen.

Så kan en spørre: Var det noen funn fra analysen som jeg som fagansvarlig for studiet ikke visste fra før? Nei - jeg kjenner praksisfortellingene i NAV og gjenkjenner refleksjonene og det faglige innholdet. Ja - jeg vet mer spesifikt hvordan studentene resonnerer, hvilke faglige begreper de faktisk bruker, og hvordan de forener praksis og teori. Jeg har gjennom denne analysen styrket mine intensjoner om å fremme studentenes evner til både abstraksjon og konkretisering. De nærgående studiene av arbeidskravene støtter rasjonalet bak å bruke skriftlige refleksjon som en aktivitetsramme for læring. Jeg mener at skrivingen stimulerer innsikten i sammenhenger mellom det partikulære og det generelle, altså mellom praksis og teori. Studenter som står midt i krevende praksiser, får anledning til å ta et skritt til siden, og betrakte egne handlinger og atferd fra en mer distansert metaposisjon enn de har til daglig. Halvorsen skriver i kapittel 2 at «vi må på innsiden for å komme i kontakt med erfaringen, men vi må på avstand for å forstå det som skjer med oss og mellom oss og hvordan dette henger sammen». NAV-studentenes tekster beskriver presist hvordan denne forståelsen foregår for dem.

Som undervisere formulerer vi innleveringsoppgaver tilpasset fagets egenart og studentgruppens nivå. De innleverte tekstene gir grunnlag for individuell feedback til studentene. De gir samtidig oss som undervisere et unikt innblikk i studentenes praksis, deres virkelighet og handlinger. 
I tillegg anbefaler jeg sterkt å lese slike tekster på nytt og i sammenheng, og da med oppmerksomhet på kontinuerlig forbedring av undervisningen.

Selv om det ikke er den praksisnære undervisningen og dens effekt på studentenes læring som er analysert her, er det likevel grunn til å tro at undervisningens kvaliteter har betydning. For meg som fagansvarlig har det vært viktig å undervise slik at studentene får tilgang til gode tankeredskap som hjelper dem i å binde teori og praksis sammen, og at de får muligheten til å strekke seg mentalt. Redskapene, her anvendt som analysekategorier, abstrakt - konkret og I., II. og III. ordens læring/forandring, er eksempler på redskaper som jeg mener kan bidra til en mental strekking særlig ved at begrepene eksplisitt peker både mot handling og tanke. Analysekategoriene kan gi, som vist i analysene i dette kapitlet, en pekepinn på samsvaret mellom teori og praksis og mellom deduktive og induktive prosesser i studentenes læring. Med denne innstillingen blir innleveringsoppgaver et ledd i en dialogisk undervisning, og en spennende reise for både studenter og undervisere.

\section{Litteratur}

Andreassen, T. A. \& Aars, J. (2015). Den store reformen: Da NAV ble til. Oslo: Universitetsforlaget.

Bateson, G. (1972). Steps to an ecology of mind. New York: Ballantine Books.

Bhaskar, R. \& Danermark, B. (2006). Metatheory, interdisciplinarity and disability research: A critical realist perspective. Scandinavian Journal of Disability Research, 8(4), 278-297. https://doi.org/10.1080/15017410600914329

Damasio, A. R. (2002). Følelsen av hva som skjer: kroppens og emosjonenes betydning for bevisstheten. Oslo: Pax.

Danermark, B., Ekstrom, M., Jacobsen, L. \& Karlsson, J. C. (2003). Att förklara samhället (2. utg.). Lund: Studentlitteratur.

Dysthe, O., Hoel, T. L. \& Hertzberg, F. (2010). Skrive for å loere: skriving i høyere utdanning (2. utg.). Oslo: Abstrakt forlag.

Eide, S. B., Aasland, D. G., Grelland, H. H. \& Kristiansen, A. (2008). Til den andres beste: en bok om veiledningens etikk. Oslo: Gyldendal akademisk.

Eikeland, O. (2015). Om det allmenne ved yrkespedagogikken. I O. Eikeland, H. Hiim, \& E. Schwenke (Red.), Yrkespedagogiske perspektiver (s. 13-32). Oslo: Gyldendal akademisk.

Elmholdt, C. W. (2001). Loring som social praksis på arbejdspladsen: et feltstudie af loering mellem person, informationsteknologi og organisation. $\mathrm{PhD}$, Aarhus Universitet, Risskov. 
Halvorsen, G. S. (2011). Relasjonen mellom hjelper og hjelpesøkende: en studie i forståelsens og anerkjennelsens betingelser og utviklingsmuligheter. nr. 3-2011, Universitetet i Nordland, Bodø.

Hansen, H.-T., Lundberg, K. G. \& Syltevik, L. J. (2013). Nav - med brukeren $i$ sentrum? Oslo: Universitetsforlaget.

Johansen, A. (2003). Samtalens tynne tråd: skriveerfaringer. Oslo: Spartacus.

Jonsmoen, K. M. \& Greek, M. (2012). «Hodet blir tungt - og tomt» - om det å skrive seg til profesjonsutøvelse. Norsk pedagogisk tidsskrift, 96(1), 15-26.

Kunnskapsdepartementet. (2017). Forskrift om felles rammeplan for helse- og sosialfagutdanninger. Oslo: Lovdata. Hentet fra https://lovdata.no/dokument/SF/ forskrift/2017-09-06-1353

Lakoff, G. \& Johnson, M. (1999). Philosophy in the flesh: The embodied mind and its challenge to Western thought. New York: Basic Books.

Lauvås, P. \& Handal, G. (2014). Veiledning og praktisk yrkesteori (3. utg.). Oslo: Cappelen Damm akademisk.

Lave, J. \& Wenger, E. (2003). Situeret loering - og andre tekster. København: Reitzel.

Moxnes, P. (2000). Loring og ressursutvikling $i$ arbeidsmiljøet (ny utg.). Oslo: Forlaget Paul Moxnes.

Nenseth, V., Thaulow, H., Vogt, R. D. \& Orderud, G. (2010). Tverrfaglig miljøforskning - en kunnskapsstatus. Oslo: Oslo Centre for Interdisciplinary Environmental and Social Research.

Nyhus, L. (2011). Refleksjon, læring og endring på ulike nivå - et metaperspektiv. I G. Haugsbakk, Ø. Haaland \& S. Dobson (Red.), Pedagogikk for en ny tid. Vallset: Oplandske Bokforlag.

Ose, S. O. (2016). Sykefraver, HMS og inkludering. Oslo: Gyldendal akademisk.

Seikkula, J. \& Arnkil, T. E. (2013). Åpen dialog i relasjonell praksis: respekt for annerledeshet i øyeblikket. Oslo: Gyldendal akademisk.

Siegel, D. J. (2012). The developing mind: How relationships and the brain interact to shape who we are (2. utg.). New York: Guilford Publications.

Skjeseth, E. (2004). Læring på arbeidsplassen - en selvfølge? Hovedfagsoppgave i yrkespedagogikk, Høgskolen i Akershus, Kjeller.

Säljö, R. (2006). Loring og kulturelle redskaper: om loereprosesser og den kollektive hukommelsen. Oslo: Cappelen Akademisk Forlag.

Tveiten, S. (2019). Veiledning: mer enn ord (5. utg.). Bergen: Fagbokforlaget.

Ulleberg, I. \& Jensen, P. (2017). Systemisk veiledning i profesjonell praksis. Bergen: Fagbokforlaget.

Watzlawick, P. (1996). Forandring: prinsipper for hvordan problemer oppstår og hvordan de løses. Oslo: Gyldendal.

Wiben Jensen, T. \& Skov, M. (2007). Følelser og kognition. København: Museum Tusculanums Forlag. 


\title{
KAPITTEL 8
}

\section{$\AA ̊$ lære om seg selv gjennom å observere andre}

\author{
Inger Marie Bakke, Håkon Glommen Eriksen og Lene Nyhus \\ Høgskolen i Innlandet
}

\begin{abstract}
The master's level course in social science and pedagogy, 'Communication in professional contexts' at Inland Norway University of Applied Sciences, is the basis for this chapter. In the course, the students carry out observations of real-life interaction situations in different occupational contexts, and reflect on these through written work and in group counselling. The chapter presents these practice-oriented working methods as well as explains students' experiences. The most important learning objective of the programme is that the students will become more aware of their own preconceptions and values in the professional meetings. The purpose of the chapter is to shed light on what may be the value of the chosen working methods in particular, in order for the students to experience this awareness - in themselves and as valuable for their own professional practice.
\end{abstract}

Keywords: communication, relationship competence, awareness raising, observation, group counselling

\section{Introduksjon}

Vi har alle medfødte forutsetninger for å kommunisere, og vi vet intuitivt hva som er god kommunikasjon når vi opplever det (Schibbye, 2009). Å kommunisere på gode og hensiktsmessige måter kan særlig være utfordrende når vi arbeider profesjonelt med mennesker. Selv om både den som søker og den som yter hjelp bidrar inn i samhandlingssituasjonen, plasseres hovedansvaret hos fagpersonen; hvem lar du den andre være i møte med deg? Legger du føringer som begrenser den andre, eller lar du han eller hun framstå med seg selv og som seg selv?

Sitering av denne artikkelen: Bakke, I. M., Eriksen, H. G. \& Nyhus, L. (2020). Å lære om seg selv gjennom å observere andre. I Y. T. Nordkvelle, L. Nyhus, A. Røisehagen og R. H. Røthe (Red.), Praksisnœr undervisning - i praksis og teori (Kap. 8, s. 141-160). Oslo: Cappelen Damm Akademisk. https://doi.org/10.23865/ noasp.94.ch8.

Lisens: CC BY 4.o. 
Bidrar du til at ressurser frigjøres og settes i spill hos den andre? Forstår du hvordan handlingen påvirkes av konteksten handlingen foregår innenfor, og evner du å legge til rette for god samhandling? Kvaliteten på kommunikasjonen vil spille inn på det som kommer ut av samhandlingen og er selve omdreiningspunktet, slik både Aubert og Bakke (2018), Røkenes og Hanssen (2012) og Skau (2017) er inne på. Nyansering, tilpasning, videreutvikling og verdiforankring av den profesjonelle sin evne til å kommunisere i slike situasjoner krever derfor ekstra oppmerksomhet og er en livslang utfordring (Aubert \& Bakke, 2018). Vår interesse i dette kapitlet er å utforske en bestemt form for praksisnær undervisning som har som intensjon å legge til rette for utvikling og styrking av studentenes kommunikasjonskompetanse. Vi spør hvordan observasjon av andres samspill og kommunikasjon, med tilhørende refleksjons- og veiledningsprosesser, kan være et bidrag i en praksisnær undervisning med dette formålet.

Vi er en gruppe lærere som i flere år har lagt til rette for at studenter på masteremnet «Kommunikasjon i profesjonelle kontekster» ved Høgskolen i Innlandet kan bringe inn i undervisningen observasjoner fra praksisarenaer som de utdanner seg til å arbeide innenfor, som de allerede arbeider innenfor eller som de i forbindelse med studiet gjør observasjoner i. Selve undervisningsopplegget består av observasjon av kommunikasjons-/samhandlingssituasjoner som studenten selv velger, veiledning med utgangspunkt i disse observasjonene og refleksjonslogg på bakgrunn av disse observasjonene og veiledningene. Det innsamlede materialet deles, diskuteres med medstudenter, reflekteres over og brukes som innspill i utvikling av egen kommunikasjonskompetanse. Egne forutsetninger i form av blant annet forforståelser og væremåter som vi bringer med oss til møtet med den andre, og hvordan det kan prege møtet, blir satt på dagsordenen.

Praksisnær undervisning blir i vår sammenheng forstått som å ta utgangspunkt i det som er praksisnært for studenten, og som Grete Halvorsen i kapittel to i denne boka omtaler som «menneskets eksistensielle virkelighet og dets handlinger i denne virkeligheten». Halvorsen identifiserer det praksisnære elementet i undervisningen til å handle om det eksistensielle - livet og virkeligheten. På vårt studium handler dette om 
at studentene inviteres til å bringe inn egne erfaringer fra levd liv, inkludert yrkespraksis, samt erfaringer som gjøres gjennom observasjon av andre og gjennom refleksjoner over disse erfaringene, alene og i samspill med medstudenter og lærere.

Kapitlet bygger på lærergruppas erfaringer og fagutvikling over flere år, hvor det også inngår kontinuerlige samtaler med studenter, lesing av deres skriftlige arbeider og lytting til deres tilbakemeldinger. I ett av studentkullene har vi gjennomført noe mer systematiske undersøkelser, men ikke slik at vi vil presentere dette som en kvalitativ studie, men som erfaringsbasert fagutvikling.

Videre i dette kapitlet vil vi først gjøre rede for undervisningsopplegget ved å presentere viktige læringsmål ved studiet, for deretter å gå dypere inn i begrepet kommunikasjon og sentrale faglige tema og utfordringer i studiet. Vi tar for oss hvordan vi som lærere vurderer, blant annet ved hjelp av studenters erfaringer, hvordan dette praksisnære undervisningsopplegget er en vei for studentene inn til deres egen forforståelse. Avslutningsvis vil vi oppsummere og reflektere over sider ved det praksisnære elementet i undervisningsopplegget.

\section{Viktige læringsmål i studiet}

Emnet «Kommunikasjon i profesjonelle kontekster» er en videreutdanning for yrkesutøvere og studenter som arbeider med mennesker. Studiet kan tas som valgemne innen masterutdanninger i sosialfag og pedagogikk ved Høgskolen i Innlandet. Studentene er i hovedsak voksne yrkesutøvere som gjerne har flere års yrkeserfaring, mens noen er yngre og i starten av sin yrkeskarriere. Hensikten med emnet er «å bidra til at yrkesutøveren legger til rette for samhandling slik at den (de) andre møtes som deltaker(-e) og opplever seg sett, hørt og forståt, samtidig om hensikten med kommunikasjonen ivaretas» (HINN, 2019).

Læringsmålene som søkes nådd er mange, og det brukes flere arbeidsmåter i undervisningen for å nå målene. Et av læringsmålene er at studenten skal oppnå inngående forståelse for hvordan egne forutsetninger kan virke inn på samhandlingssituasjoner med den (de) andre. I forlengelsen av dette er blant annet egne forforståelser og egen bakgrunn 
og erfaringer sentrale. Å stille seg kritisk til forhold som kan ha innvirkning på profesjonelle samhandlingssituasjoner, er blant ferdighetene som blir vektlagt.

De læringsmålene som særlig søkes oppnådd gjennom det undervisningsopplegget vi har fokus på her, dreier seg umiddelbart om å bli kjent med egne forutsetninger i form av blant annet forforståelse, bakgrunn og væremåter og hvordan det kan virke inn på kommunikasjonen. I studiets emneplan (HINN, 2019) står det at det legges til rette for «prosesser der den enkelte blir bedre kjent med seg selv og sine forutsetninger for å samhandle». Når egne forutsetninger studeres, innebærer det også at studentenes forståelse av, bevissthet om og holdning til makt, strukturer og regelverk belyses.

Premisset som ligger til grunn for læringsmålene, er at egne forutsetninger påvirker kommunikasjon på godt og vondt, bevisst og ubevisst. Dette er forhold som vi i mange tilfeller ville endre hvis vi ble bevisst hvordan det påvirker oss og samspillet. Samtidig er det slik at endring i sosiale samspill også avhenger av hvilken makt og innflytelse vi har på strukturene eller rammene som kommunikasjonen inngår i.

Det er en etisk forpliktelse å være bevisst oss selv og våre forutsetninger i møte med den (de) andre, for at våre væremåter og forforståelser skal kunne påvirke kommunikasjonen på måter vi mener er gode. Dette underbygges blant annet i Fellesorganisasjonens etiske grunnlagsdokument for barnevernspedagoger, sosionomer, vernepleiere og velferdsvitere (Fellesorganisasjonen, 2015). Den samme forpliktelsen gjelder med hensyn til å være bevisst de sosiale strukturene som danner rammene eller konteksten for kommunikasjonen, og hvordan disse håndteres og utfordres. Regelverk og rammer legger premisser, men den enkelte yrkesutøver kan ikke dekke seg bak regelverket eller systemet i møtet med den andre.

\section{Å kommunisere i profesjonelle kontekster - hva står på spill?}

Kommunikasjon utgjør en tverrfaglig og flerfaglig fordring: å møte mennesker på gode måter og bidra til vekst, læring og utvikling. Ingen 
enkeltfag eier denne fordringen, og vi henter teorier og perspektiver fra ulike fag og disipliner. Selve tilnærmingsmåten i det didaktiske opplegget bygger imidlertid historisk på utviklingspsykologi, noe vi kommer mer tilbake til. I tillegg bygger vi på kunnskap fra både systemiske paradigmer, humanistisk filosofi og kritisk realistisk vitenskapsfilosofi. I det følgende redegjør vi først for hva vi legger i begrepet kommunikasjon i profesjonelle kontekster. Deretter går vi nærmere inn på hva som kan påvirke denne kommunikasjonen.

\section{Kommunikasjon}

Kommunikasjon blir i dette emnet forstått i svært vid betydning, som det vi grovt sett kan betegne som relasjonell ontologi, og inkluderer relasjoner på flere nivå av virkeligheten. Med støtte i vitenskapsteori og Bhaskars «four-planar social being» (Bhaskar \& Danermark, 2006) inkluderes menneskets relasjon med seg selv i tillegg til sosiale relasjoner mellom mennesker, relasjoner til sosiale strukturer som for eksempel økonomiske, kulturelle og organisatoriske strukturer, og våre materielle og kroppslige transaksjoner med naturen. Denne forståelsen av kommunikasjon kan i videste forstand innebære at «alt kommuniserer», og at alt er kommunikasjon og relasjon.

Et annet viktig poeng i kommunikasjon er distinksjonen mellom form - måten det kommuniseres på, og innhold - hva kommunikasjonen handler om.

Fokus i dette studiet er at kommunikasjonen er både verbal og nonverbal, og foregår enten i rent fysiske møter, eller i sosiale medier. Kommunikasjon gjennom sosiale medier blir mer og mer vanlig, også innenfor hjelpende yrker. At stadig mer av samhandlingen mellom for eksempel NAV-ansatte og -brukere foregår digitalt, er et eksempel på denne utviklingen og et uttrykk for at kommunikasjon i profesjonelle kontekster har mange dimensjoner.

Kommunikasjon kan dreie seg om formidling av informasjon, slik tilfellet kan være i en digital NAV-relasjon, eller om realisering av gitte mål, som for eksempel innenfor pedagogisk virksomhet eller behandling. Her kan møtene være både fysiske og digitale. I tillegg kan kommunikasjon i 
profesjonelle relasjoner handle om å bli kjent med, eller støtte, den andres selvutvikling, slik tilfellet kan være i en mer terapeutisk preget samtale, som for eksempel innenfor barnevernet, eller i en mer veiledningspreget samtale, som for eksempel hos skolerådgiveren.

I situasjoner hvor den profesjonelle er hjelper og samtalen i utgangspunktet kan ha terapeutisk eller veiledende karakter, vil det også oppstå situasjoner hvor kommunikasjonen dreier seg om allmennmenneskelige temaer som, litt høytidelig formulert, kan handle om det gode liv for den enkelte og i fellesskap, altså etikk og politikk. I slike kommunikasjonssituasjoner er det tematisk sett en større likhet mellom den profesjonelle og samtalepartneren, og kommunikasjonen og målsettingene for samhandlingen vil i mindre grad bli preget av for eksempel terapeutiske mål og mer av en åpen utforskende samtale. Gjennom den undersøkende samtalen kan for eksempel ulike måter å leve livet på anerkjennes og følgelig bli et bidrag inn i en anerkjennelseskamp som gir grunnlag for en mer rettferdig fordeling av ressurser i samfunnet (Honneth \& Holm-Hansen, 2008; Høilund \& Juul, 2005, Skjervheim, 1996).

Profesjonell kommunikasjon innebærer også grunnleggende sett en danningsprosess, for begge parter. Her legger vi til grunn et sosialpedagogisk danningsbegrep (Mathiesen, 2018) som tydeliggjør danningens deskriptive og normative side. Den deskriptive dimensjonen ved danningsbegrepet innebærer at danning skjer uansett om vi er klar over det eller ei, samtidig kan vi ha en ønsket retning for danningsprosessen, som utgjør den normative dimensjonen. Danningsorienteringen ligger så å si implisitt i den profesjonelles væremåte i møte med for eksempel en elev. Den profesjonelle vil kunne framstå som et forbilde som den andre kan strekke seg etter (Torjussen, 2011). En lærer kan gjennom undervisning og gjennom å være et forbilde, hjelpe en elev til mer og mer å bli en jevnbyrdig samtalepartner.

\section{Kontekst - profesjonell kontekst og kontekst for det enkelte møtet}

Som allerede nevnt forstås en profesjonell kontekst i dette studiet som en hvilken som helst kontekst i arbeidslivet, offentlig og privat, hvor en 
eller flere yrkesutøvere bidrar til andre menneskers læring og livskvalitet. Typiske profesjonelle kontekster som studentene arbeider innenfor, er helsetjenester, barnehager, skole, barnevern og rusomsorg. Konteksten består av strukturer som for eksempel økonomi, organisasjon, kunnskap, lovverk og teorier, og den vil alltid legge premisser for det som kan skapes og framtre i det profesjonelle møtet. Det er en viktig målsetting i studiet å skape bevissthet rundt hvordan disse ulike profesjonelle kontekster virker inn på (for)forståelse og handlemåter. Problematisering av dette går som en rød tråd gjennom studiet.

Det er også nødvendig å rette blikket mot den mer konkrete konteksten for det enkelte møtet. Det er kjent fra faglitteratur, på tvers av fag og disipliner, at måten den andre blir møtt på, har stor betydning for hvordan samspillet utvikler seg, og for hva som får mulighet til å tre fram i samspillet (Aubert \& Bakke, 2018). Relatert til at samspill kan være mangfoldige, men også flyktige og sårbare, er det den profesjonelles ansvar å skape rammer som gir rom for å handle adekvat og til den andres beste, for eksempel ved å skape et klima for møtet som inviterer den andre til deltakelse.

Ifølge Batesons kontekstbegrep, referert hos Jensen og Ulleberg (2011, s. 99), er det viktig å være oppmerksom på den psykologiske forståelsesrammen eller den mentale rammen vi forstår et fenomen eller en observasjon innenfor. Dette har å gjøre med forforståelser, som vi vil komme mer inn på. Det har også å gjøre med hva som faktisk møter oss i samhandlingen, for eksempel i form av det Bateson betegner som kontekstmarkører (Jensen \& Ulleberg, 2011, s. 103). Kontekstmarkører handler om digitale eller analoge tegn eller signaler, gjennom språk, atferd og omgivelser, som for eksempel fysiske omgivelser i form av valgt møtested for en samhandlingssituasjon. Et kontor signaliserer noe annet enn et klasserom eller en kafé. Det vil være kontekstforståelsen, eller rammeforståelsen som vi gjerne kaller det på studiet, som avgjør hva som framtrer som informasjon for partene som inngår i samhandlingen, hva som oppfattes og hvilken mening det tillegges. Konteksten, eller rammen, er ifølge Bateson en meningsbærende helhet, og meningen med denne helheten framstår for oss blant annet gjennom disse markørene. Framstår helheten utydelig eller forvirrende, blir det vanskelig å opprettholde en brukbar 
kommunikasjon (Jensen \& Ulleberg, 2011, s. 103). Det er den profesjonelles ansvar å aktivt skape en ramme, gjennom språk, atferd og tilrettelegging av for eksempel fysiske omgivelser, tidsbruk osv., som markerer, fra den profesjonelles ståsted, hva som er viktig i møtet. Samtidig vil den profesjonelle ikke uten videre kunne forstå den andres forståelsesramme, men må forholde seg undrende og spørrende til den.

\section{Egne forutsetninger}

Egne forutsetninger i form av forforståelser, væremåter, bakgrunn, opplevelser, evner og karaktertrekk spiller også inn på tolkning av rammene og på samhandlingen. Dette skjer direkte, for eksempel i hva vi ser eller ikke ser, hva vi hører eller ikke hører. Egne forutsetninger spiller også inn på hvordan vi tolker situasjonen, hva vi vurderer som godt eller dårlig, hvilke oppmerksomheter og oppgaver vi trekkes mot, eller viker bort fra. Påvirkningen skjer enten vi er oss det bevisst eller ikke. Potensialet i å utnytte en bevisst innsikt i disse omstendighetene ligger i å kunne revurdere for eksempel egne forforståelser med hensyn på om de er sanne, gode eller produktive. Det kan bidra til å unngå at forforståelser påvirker oss på usaklige eller på negative måter.

Undersøkelsen av forforståelser kan virke frigjørende, vi kan oppdage og stille oss kritiske til forforståelse eller det vi påvirkes av. Ifølge filosofen Charles Taylor har vi ansvar for å bli bevisst og frigjøre oss fra forforståelser som vi mener er usaklige, usanne eller dårlig begrunnet. Han omtaler det som radikal selvrefleksjon som innebærer refleksjon over egne verdier. Dette er en etisk oppfordring om å forbedre egne forutsetninger for å forholde seg godt til andre (Rogers, 2003; Taylor, 1985). Undersøkelser av egne forutsetninger i form av forforståelser handler både om å fri seg fra uhensiktsmessig påvirkning og om frihet til å velge hvilke holdninger og verdier som skal prege egen yrkesutøvelse. Her mener vi det ligger en danningsmulighet for den profesjonelle i det å ta på alvor den etiske utfordringen forbundet med å granske egne verdier og foreta bevisste valg fundert på etisk refleksjon.

For at fenomen som forforståelser for eksempel i form av virkelighetsoppfatninger, forventninger og verdier og erfaringer fra livsopplevelser 
skal kunne hentes fram, må noe settes i bevegelse (Aubert \& Bakke, 2018). Spørsmålet vi går nærmere inn på nedenfor, er hva som kan sette følelser, tanker og kroppslige responser i sving. Vi er bevisste på å trekke en distinksjon mellom pedagogiske og terapeutiske rammer og understreker at vi er innenfor en pedagogisk ramme i dette emnet. Arbeid med egne forutsetninger handler også om å få tilgang til egne ressurser gjennom å bli mer bevisst på og i stand til å forholde seg til erfaringene. For noen kan dette virke truende. Utfordringen forbundet med å granske egne forutsetninger blir tatt opp med studentene allerede ved starten av studiet, og den enkelte blir oppfordret til å tenke over og være tydelig på egne grenser. Bevisstgjøring på hvor egne og andres grenser går, samt respekt for grenser og taushetsplikt, er et kjerneelement i denne undervisningen. Vi skal se nærmere på det pedagogiske opplegget, hva vi gjør, hva vi vil med det vi gjør, og hvilke forforståelser undervisningen bygger på.

\section{Praksisnær undervisning - en vei inn til forståelse av egne forutsetninger}

Opplegget for den praksisnære undervisningen har utgangspunkt i et undervisningsopplegg utviklet ved Tavistock-klinikken i London på 1950-tallet. Hensikten den gang var å legge til rette for utvikling av klinisk kompetanse hos fagpersoner innenfor barne- og ungdomspsykiatrien. I Norge er dette videreutviklet og tilpasset universitets- og høgskolekonteksten (Abrahamsen, 2004; Aubert \& Bakke, 2018).

I vårt undervisningsopplegg inviteres studentene til å bringe inn erfaringer fra praksis, det vil si fra eget liv samt erfaringer som gjøres gjennom observasjon av samspill mellom deltakere i en profesjonell samhandlingssituasjon. I tillegg blir studentene også invitert til å reflektere over disse erfaringene, alene og i samspill med medstudenter og lærere.

Praksis har ifølge Halvorsen (kap. 2) både en værens- og en handlingsdimensjon. Væren knyttes til det sansbare. Handlingsdimensjonen viser til hvordan forholde seg til det en sanser. Gjennom refleksjon vil en få hjelp til å sette ord på og begripe det som sanses. I vår praksisnære tilnærming går også veien fra sansning til forståelse. Intensjonen er at studentene gjennom de forskjellige prosessene som observasjon, skriving, refleksjon 
og veiledning i grupper skal få muligheter for eksponering som setter i gang følelser, tanker og kroppslige responser, som videre gir impulser til refleksjon, bearbeiding, nye tanker og nye kroppslige responser.

Observasjon og refleksjoner rundt det observerte vil noen ganger utløse konkrete opplevelse som rister og beveger oss, og viser oss at måten vi har forstått på har vært alvorlig feil. Slike opplevelser vil for de fleste bidra til endring, noen ganger en varig endring. Andre ganger kan det opplevde bare være svakt sanset, og ikke så lett å sette ord på eller begripe, slik Halvorsen i kapittel 2 er inne på. Men ved å bli utfordret til å beskrive og fortolke, og gjennom å reflektere over fortolkingene som studenten selv har gjort av det som ble observert, kan man komme på sporet av og tydeliggjøre hva en forsto på grunnlag av. Og gjennom møtet med andre medstudenters fortolkninger bevisstgjøres også spennvidden i hva som kan være mulige fortolkninger. Ved å utvide fortolkningsmulighetene gis studentene et valg som i neste omgang kan føre til at de erfarer at det er flere mulige måter å forstå både seg selv og det observerte på. I slike prosesser er det imidlertid viktig at det utøves forsiktighet og ydmykhet i stedet for skråsikkerhet, når det gjelder hvordan hendelser kan fortolkes og forstås.

Når fenomenet er identifisert, vil arbeid med teoristoff og begreper hjelpe den enkelte til å gjøre koblinger mellom sin egen opplevelse og erfaring, og abstrakte begrep. Intensjonen er at erfarings- og teorilæring finner sammen. Egne erfaringer blir løftet opp og forstått i forhold til nye, teoretiske begrep, og teoretiske begrep bidrar til å sette ord på og ramme inn tidligere erfaringer. Som vi kommer tilbake til, er våre erfaringer at studentene greier å få erfaring og teorilæring til å finne sammen, og denne bevisstgjøringen om egne forutsetninger for kommunikasjon er noe av den viktigste læringen som skjer i dette studiet.

\section{Erfaringer med undervisningsopplegget}

Praksisnær undervisning innebærer, som vi har vært inne på, tilrettelegging av prosesser slik at studentene får en opplevelse av «å være i verden», samtidig som de utfordres til å reflektere over seg selv i relasjon til denne verden. Halvorsen (kap. 2) skriver med referanse til Heidegger og 
Skjervheim at vi må våge å stå i et direkte forhold til oss selv for å få tak i hvor vi befinner oss. I dette undervisningsopplegget er disse aspektene integrerte deler av hele læringsprosessen. For å vise hvordan dette konkret er utformet, går vi gjennom de ulike leddene i undervisningsopplegget. Stikkord er: observasjon av samspill, skriving av observasjonsnotat, veiledning i grupper, refleksjonslogg, deretter gjentakelse av de samme leddene, samt skriving av eksamensessay avslutningsvis.

\section{Observasjon av samspill}

I første ledd av opplegget, observasjon av samspill, skal studentene først og fremst være til stede, bruke alle sansene sine og ta inn inntrykk mest mulig uten filter. De skal derfor inneha en rolle som «beskjeden gjest» hos en annen yrkesutøver. Som beskjeden gjest skal studenten holde seg i bakgrunnen og ikke involvere seg direkte i det som skjer. Fokus for observasjonen skal være samhandlingen mellom partene, og målet er å ha et bredest mulig fokus og absorbere mest mulig av det som skjer, både på det nonverbale og det verbale planet. I tillegg skal studentene være oppmerksomme på hva som skjer på deres egen «indre bane», så som indre dialog og kroppslige responser.

Mange studenter opplever at det er særlig krevende å observere det som skjer mellom partene, og sier at de i starten har behov for veiledning slik at de vet hva de skal se etter. Det å «sitte på hendene sine», slik studentene blir instruert til å gjøre, er også utfordrende. Observasjon av samspill, uten å kunne intervenere, kan oppleves smertefullt. Å reflektere over denne smerten vil i neste omgang kunne bidra til økt innsikt i hvorfor denne smerten oppstår, og hvordan den preger eget handlingsmønster. I tillegg til økt bevisstgjøring er dette også trening på å utholde ubehaget forbundet med å vente med å intervenere til du har oversikt over helheten i situasjonen. Røkenes og Hanssen (2012) kaller dette for «være-i-kompetanse» og viser til viktigheten av å romme den andres følelser og opplevelser samt bearbeide og speile tilbake på en slik måte at det oppleves hjelpsomt av den som søker hjelpen din.

En siste dimensjon ved observasjonsarbeidet som vi skal nevne her, er at studentene erfarer at observasjonen blir mer nyansert og detaljrik når 
de er avskåret fra å delta i samhandlingen. Blikket blir skarpere, og betydningen av at observasjonene er realistiske og foregår i konkrete, praktiske situasjoner, trekkes fram. Studenter erfarer at det oppleves veldig ekte å observere virkelige situasjoner og de må bruke alle sansene sine. De gjør oppdagelser i observasjonene av blant annet hvor viktig kroppsspråk er, og hvor viktig plasseringen i rommet er. De får et større bilde, de ser detaljer og viktigheten av de små tingene. Flere sier de opplever det som utbytterikt å observere en kollega, og at de får nytt perspektiv både på den de observerer og på arbeidsplassen. Til sammen gir dette muligheter for opplevelser som igjen kan sette følelser, tanker og kroppslige responser i spill. Emosjonell læring blir et viktig stikkord her.

\section{Skriving av observasjonsnotat}

Det andre leddet i det praksisnære undervisningsopplegget innebærer at studenten skriver et observasjonsnotat i etterkant av observasjonen. Dette gir en mulighet til å koble egne ord til det som er sanset eller opplevd, og studentene vi har snakket med bekrefter at vekslingen mellom observasjon og skriving om observasjonen er viktig og nyttig. Utfordringen er imidlertid å skille mellom beskrivelse, egen fortolkning og egne refleksjoner. Å beskrive uten å tolke kan være utfordrende. På den andre siden er dette en ferdighet fagpersonen må øve seg på, da en beskrivelse av situasjonen vil være mer åpen, mindre verdiladet og gi et bedre grunnlag for samtaler og diskusjoner med kolleger. Å skille mellom beskrivelse og egne fortolkninger gir også et utgangspunkt for å reflektere over, og stille spørsmål ved, hva en forstår på grunnlag av. Beskrivelsen åpner for flere mulige tolkninger, og tolkninger er en vei inn til egen forforståelse. Refleksjonene som følger i etterkant, bidrar ytterligere til å sette ord på og tydeliggjøre denne forforståelsen.

\section{Veiledning i grupper}

Observasjonsnotatet omtalt ovenfor utgjør i neste omgang veiledningsgrunnlaget og brukes aktivt i den gruppeveiledningen som studentene deltar i. Dette er det tredje leddet i arbeidsprosessen. Det at veiledningen 
gir tilgang til andres tanker og refleksjoner, gir slik studenter erfarer det mulighet til flere perspektiv på det de selv har opplevd og erfart. Refleksjonselementet i læringsprosessen blir med andre ord ytterligere forsterket. Studentene rapporterer at de synes det er lærerikt å høre om medstudentenes observasjoner og refleksjoner over disse. Viktige dimensjoner av forutsetninger for kommunikasjon som vi lærere har erfart blir lagt under lupen i veiledningsprosessene, er studentenes egne erfaringer og forforståelser, egne evner og væremåter, karaktertrekk, egne tolkningsmønstre av situasjoner og oppmerksomhet på skillet mellom hva som faktisk skjer og hvordan observatør (studenten) fortolker det som skjer. Studentens egen forforståelse får imidlertid ekstra stor oppmerksomhet og kan mellom annet innebære en bevisstgjøring av hvilke typer kommunikasjonssituasjoner som oppleves behagelige eller ubehagelige, og som man ubevisst søker inn i eller ut av uten å være klar over det. En tilsiktet effekt av veiledningen er derfor å gjøre studenten bedre i stand til å forholde seg til og ta ansvar for måten egen forforståelse kan påvirke ham eller henne på.

I våre samtaler med studenter har vi erfart at de opplever at veiledningen er virkningsfull og gir anledning til diskusjoner og erfaringsdeling. De uttrykker at de blir mer bevisst egne forutsetninger som for eksempel egen forforståelse og reflekterer mer over hvordan den virker inn på samhandlingssituasjoner. De opplever også at de blir bedre kjent med seg selv og mer opptatt av hvordan de kan møte den andre best mulig. De fokuserer mer på egne kommunikasjonsferdigheter, og legger vekt på at de ønsker å lytte til den andre. Oppmerksomheten rettes også mot hvilke ord som brukes, og studentene tilstreber å reflektere kritisk, både over innholdet $\mathrm{i}$ og rammene for kommunikasjonen. Noen sier at de har utfordret seg selv i løpet av denne perioden, og at de nå tør mer.

Studentene er også tydelige på at veiledning bidrar til at teoretiske begrep kobles til innholdet i det som blir observert og diskutert i gruppene, at det er svært betydningsfullt og bidrar til økt refleksjon og utvikling av ny innsikt, særlig når det gjelder å forstå hvordan egne forutsetninger spiller inn på samhandlingssituasjoner. Dette åpner igjen for reflekterte valg i forhold til hvordan en selv ønsker å framstå som fagperson. Noen studenter sier også at denne vekselvirkningen mellom teori 
og praksis som de opplever gjennomsyrer dette undervisningsopplegget, gjør at de ønsker å utnytte arbeidskravet til å lære mest mulig om seg selv. Slik vi erfarer det, gir studentenes dypdykk i egne forutsetninger impulser til nye oppdagelser.

Gjennom møtene i veiledningsgruppa foregår treningen så å si på to nivåer. Vi har ett nivå med det planlagte og organiserte og for studentene lett synlige undervisningsopplegget som består av de seks leddene vi beskriver her. Men treningen og bevisstgjøringen foregår også på et annet og kanskje mindre synlig plan for studentene, nemlig gjennom å delta i selve prosessen i veiledningsgruppene. Da er det ikke bare slik at studentene legger fram, og reflekterer over, egne observasjoner og fortolkninger slik de er gjort i fortid og som forberedelse til møtet. Det å delta i gruppemøtet som den som legger fram eller som den som bidrar med refleksjoner, utfordrer deltakerne om lag på samme måte som ved observasjonen. Forskjellen er at det nå ikke bare er observasjon som berører, men også det å være deltaker i veiledningsgruppa. Da er utfordringen å bevisstgjøre seg hvordan man opplever å lytte til den andre med et åpent sinn, tåle andres fortolkninger, og være den som eksponerer seg gjennom å legge fram eller å kommentere.

\section{Refleksjonslogg}

Det fjerde leddet i undervisningsopplegget handler om at studentene skriver en fri refleksjonslogg der de igjen skal sette ord på opplevelser og erfaringer, samt en refleksjon over hva som ble særlig viktig for dem selv i veiledningsøkta. Her kan studentene gjerne komme inn på refleksjoner over hvorfor de reagerer som de gjør, og gjennom dette møte sine egne grenser for hva som kan oppleves for intimt til å dele. Uansett hvor kort eller langt den enkelte ønsker å gå i refleksjoner over seg selv, sine responser, oppdagelser osv., gjelder det et ubetinget krav om respekt og konfidensialitet for den som deler.

Som lærere og veiledere har vi solid erfaring med at læring foregår både på et ytre plan i samspillet mellom studentene og lærer, og på et indre plan, i studentens egne indre prosesser. Noen studenter evner, og 
ikke minst ønsker, å eksponere seg. Andre er stille og kan virke tilbaketrukne. Refleksjonsloggene som skrives i etterkant, viser imidlertid at refleksjonene kan være vel så dype, og læringsutbyttet vel så stort for de «stille» studentene. Som veileder må en derfor tilstrebe den vanskelige balansegangen mellom å utfordre og samtidig respektere den enkelte sine grenser. Dette gjør vi særlig gjennom metakommunikasjon, i gruppa, hvor vi samtaler om hvordan vi samtaler i gruppa og hvordan dette fungerer for studentene. Vi legger stor vekt på å skape rammer og et klima i veiledningsgruppene som skal gir om for åpenhet og deling.

\section{Gjentakelse av de fire første leddene}

Når de fire første leddene er gjennomført, gjentas prosessen på nytt, det vil si med ny observasjon, logg, veiledning i gruppe og refleksjonslogg. Poenget med å observere den samme relasjonen på nytt er at studentene får mulighet til å erfare at enhver relasjon kan sees som ny, og må møtes med et friskt blikk. Viktigheten av å stille seg åpen for nye dimensjoner i et samspill som virker kjent og kanskje forutsigbart, er en viktig erfaring å ta med seg.

Flere studenter trekker fram viktigheten av at arbeidet de gjør på studiet går igjennom flere ledd og strekkes ut i tid, det vil si over flere uker. Dette gir rom for refleksjon mellom de ulike leddene, og det skjer fordypning underveis. Det trekkes fram at denne type arbeidskrav over tid er annerledes enn hva mange er vant til fra andre studieemner, og at det her er mulig å internalisere begrep på annen måte. Dette handler for eksempel om at studenten kan prøve seg fram med et begrep i refleksjonsloggen eller i gruppeveiledningen, og få respons fra andre, og over tid gjøre begrepet til sitt eget. Studenter trekker for øvrig også fram at vekslingen mellom de ulike leddene i prosessen åpner opp for egen refleksjon og bevisstgjøring i større grad enn å bare lese i en bok.

Generelt, for alle leddene i opplegget under ett, erfarer studenter at arbeidsmåtene er veldig praktiske, det er noe «de gjør», og de må bruke alle sider av seg selv. Arbeidsmåtene er også relatert til egen jobb. Studenter trekker i tillegg fram at de har blitt mye mer bevisste på egen 
kommunikasjon og generelt blitt mer kritiske. De har begynt å reflektere mer i selve handlingene, men også etterpå. Enkelte peker på at det er både godt og vondt å bli mer bevisst egne forutsetninger, fordi det er mye å tenke over og mange spørsmål som melder seg, både i egen kommunikasjon og i observasjon av kollegers kommunikasjon på jobben. Enkelte sier de spør kolleger mer nå om hvorfor de gjør som de gjør, og at de har blitt mer nysgjerrige. Det påpekes at det samtidig er viktig ikke å overtenke hele tiden ut fra faren for å miste den «naturlige kommunikasjonen», den kommunikasjonen som er umiddelbar.

\section{Eksamensessay}

Undervisningsopplegget avsluttes med eksamensessay. Dette er det sjette og siste leddet i læringsprosessen. Her får studenten anledning til å beskrive, reflektere over og drøfte egen læreprosess opp mot relevant teori valgt ut på studiet eller som de selv trekker inn. Andre arbeidsmåter som også har vært brukt i løpet av semesteret, men som vi ikke går inn på her, vil også spille inn. Tanken er at alle tilnærmingene i sum skal bidra til å stimulere utviklingen av egen kommunikasjons- og relasjonskompetanse. Tilbakemeldinger fra studenter fra arbeidet med eksamensessayet, er at det er nødvendig å tvinge seg selv til å sette ord på og bli bevisst egen utvikling, og at dette avsluttende eksamensarbeidet er særlig utbytterikt.

Som lærere på studiet har vi erfart at studentene vektlegger at refleksjonen i tilknytning til de ulike delene av opplegget har vært betydningsfulle for dem i deres bevisstgjøring om egne forutsetninger for kommunikasjon. Når det gjelder betydning av det praksisnære i disse prosessene, ser vi at det gir mulighet til å bli bevisst og trene på ulike ferdigheter som inngår i fagpersonens kommunikasjonskompetanse.

\section{Om det praksisnære i undervisningen - avsluttende refleksjoner}

Som lærere har vi erfart, gjennom flere år, at det «skjer noe» med studentene på masteremnet vi skriver om i dette kapitlet, «Kommunikasjon i profesjonelle kontekster». Vi har vist i gjennomgangen av undervisningen, 
ledd for ledd, hvordan vi erfarer at studenter opplever det, og hvordan de formulerer seg om sine erfaringer. Vi vil oppsummere våre erfaringer og knytte dem til noen dimensjoner i det følgende.

For det første mener vi undervisningen, gjennom alle ledd, bidrar til at studentene får impulser til og blir oppmerksomme på det som skjer i det «ytre» (omgivelsene) og det som skjer i det «indre» (egen kropp), og samspillet mellom det ytre og det indre. Studentene erfarer at de blir mer oppmerksomme og bevisste på andres og egen praksis enn de har vært tidligere. Da tenker vi her på praksis i vid forstand av begrepet, slik det er skrevet om i kapitlene 1 og 2 i denne boka.

For det andre øker studentene sin oppmerksomhet mot skillet mellom observasjoner og tolkninger og beskrivelser av disse. Dette er ikke et skarpt skille, da all beskrivelse av observasjon har implisitte tolkninger. Det er like fullt et viktig analytisk skille som har store praktiske og etiske konsekvenser når det gjelder kommunikasjon. Det praksisnære i dette handler særlig om økt oppmerksomhet mot praksis, det vil si, mot hva som konkret eller virkelig skjer, i omgivelsene og hos meg i det indre. Det handler også om oppmerksomheten mot å kunne skille mellom selve fenomenet og abstraksjonen, begrepet for fenomenet. Eksempelvis erfarer vi i veiledningsgruppene at det kan benyttes ulike ord og begrep om samme fenomen, eller motsatt, at vi bruker samme begrep og tror vi snakker om samme fenomen, men oppdager at vi ikke gjør det. Heri ligger også praksis-teori-dimensjonen som vi kommer tilbake til under.

For det tredje ser vi at studentene øker sin oppmerksomhet mot hva de selv gjør og sier i egne profesjonelle møter, og hvorfor, og at de oppøver tydelighet i å skille mellom det som er deres eget, for eksempel tolkninger, og det som tilhører «den andre». Dette er noe vi mener er en kjernekompetanse for den profesjonelle: å kunne skille mellom hva som tilhører en selv og hva som tilhører den andre, for eksempel av følelser, oppfatninger, vurderinger og virkelighetsbeskrivelser. Der det skjer krenkelser i det profesjonelle møtet, er det gjerne overskridelse av denne type grenser mellom den profesjonelle og den andre, på individ- eller institusjonelt nivå.

For det fjerde mener vi at studentene får erfaring med og oppøver oppmerksomt nærvær her og nå. Dette handler om økt oppmerksomhet 
mot hvordan enhver situasjon også befinner seg i et spenn mellom fortid, nåtid og framtid. Dette kan handle om hvordan den profesjonelle kan ta med seg sine forforståelser fra fortid, for eksempel fra tidligere møter inn i nåsituasjonen, på godt og vondt, eller hvordan deres forventninger om hva som er mulig i framtid, også preger nåsituasjonen.

En femte dimensjon er at vi mener studentene oppøver en rikere forståelse av hvor sammensatte og komplekse samspillsituasjoner er. Studentene utvikler sin evne til å se og lytte, og de utvikler sitt språk når det gjelder å beskrive hva de ser, hører og legger merke til. Samtidig utvikler de ikke minst sin interesse for og sitt engasjement i å forstå hva som ligger bak det observerbare, for eksempel bevisste og ubevisste intensjoner og forforståelser eller strukturelle forhold. Denne dimensjonen har sammenheng med det vi ovenfor har trukket fram om observasjon og tolkning, men det handler også særlig om økt forståelse av dybden i enhver kommunikasjonssituasjon.

Som det sjette punktet vil vi trekke fram hvordan vi mener denne undervisningen, med ganske enkle midler, kan bidra til studentenes muligheter for å koble praksis og teori, eller sagt mer presist, koble virkelige fenomen med abstraksjoner, begreper, om fenomenene. I skrivearbeidet på emnet, og i alle samtaler i gruppeveiledningen, får studentene prøve seg fram med egne begrep og de får møte medstudenters begreper og lærernes begreper om samme fenomen. Begrepene blir hele tiden knyttet til observasjonene, tolkningene og beskrivelsene, og vi mener det blir tydeligere for studentene at fenomen og begrep kan kobles. I tillegg til at det blir tydelig at det dreier seg om to ulike størrelser. I dette inngår det også en bevisstgjøring, i tråd med ontologisk realisme, at virkeligheten er noe mer enn de begrepene vi har om den.

Avslutningsvis kan man spørre om praksisnærhet er nødvendig for å få til disse bevisstgjøringsprosessene som er oppsummert her. På dette masteremnet legger vi til grunn at berørthet er viktig, og da mener vi at det kreves et møte med noe utenfor oss som berører. Dette utenfor som berører, kan i pedagogisk sammenheng være en film, en tekst eller for eksempel et rollespill. Men det engasjementet og den innsikten som kommer av at noe virkelig står på spill, vil sannsynligvis være sterkere og tydeligere i en virkelig situasjon enn for eksempel ved å se en film. 
Ville det i så fall ikke ha vært enda mer effektivt for læring og utvikling hvis studentene deltok i praksis og ikke bare observerte? Kanskje ville man ved å la studentene delta i praksis ha vunnet noe når det gjelder opplevelsen av alvor og hvordan det spiller inn på berørthet og erkjennelse, men man ville sannsynligvis tapt noe av refleksjonen, åpenheten og ettertanken i en situasjon hvor studenten selv var opptatt i praksis.

\section{Referanser}

Abrahamsen, G. (2004). Et levende blikk: samspillsobservasjon som metode for loering. Oslo: Universitetsforlaget.

Aubert, A.-M. \& Bakke, I. M. (2018). Utvikling av relasjonskompetanse: nøkler til forståelse og rom for loering (2. utg.). Oslo: Gyldendal.

Bhaskar, R. \& Danermark, B. (2006). Metatheory, interdisciplinarity and disability research: A critical realist perspective. Scandinavian Journal of Disability Research, 8(4), 278-297.

Fellesorganisasjonen. (2015). https://www.fo.no/getfile.php/1311735-1548957631/ Dokumenter/Din\%2oprofesjon/Brosjyrer/Yrkesetisk\%2ogrunnlagsdokument.pdf

HINN. (2019). Emnebeskrivelse. Høgskolen i Innlandet. Hentet 28.10.19 fra https:// www.inn.no/content/view/full/153681/language/nor-NO

Honneth, A. \& Holm-Hansen, L. (2008). Kamp om anerkjennelse: om de sosiale konfliktenes moralske grammatikk. Oslo: Pax.

Høilund, P. \& Juul, S. (2005). Anerkendelse og dømmekraft i socialt arbejde. København: Reitzel.

Jensen, P. \& Ulleberg, I. (2011). Mellom ordene: kommunikasjon i profesjonell praksis. Oslo: Gyldendal akademisk.

Mathiesen, R. (2018). Dannelsesfilosofi: et sosialpedagogisk perspektiv. Tomter: InfolitenBok.

Rogers, C. R. (2003). Client-centered therapy. London: Brown Book Group.

Røkenes, O. H., Hanssen, P.-H. (2012). Bare eller briste: kommunikasjon og relasjon $i$ arbeid med mennesker (3. utg.). Bergen: Fagbokforlaget.

Schibbye, A.-L. L. (2009). Relasjoner: et dialektisk perspektiv på eksistensiell og psykodynamisk psykoterapi (2. utg.). Oslo: Universitetsforlaget.

Skau, G. M. (2017). Gode fagfolk vokser. Personlig kompetanse i arbeid med mennesker. Oslo: Cappelen Damm Akademisk.

Skjervheim, H. (1996). Deltakar og tilskodar. I H. Skjervheim (Red.), Deltakar og tilskodar og andre essays. Oslo: Aschehoug.

Stern, D. N. (2003). Spedbarnets interpersonlige verden. Oslo: Gyldendal Akademisk. 
Taylor, C. (1985). What is human agency. I C. Taylor (Red.), Philosophical papers. 1 Human agency and language (Vol. 1.) Cambridge: Cambridge University Press. Torjussen, L. P. S. (2011). Danning, dialektikk, dialog - Skjervheims og Hellesnes` pedagogiske danningsfilosofi. I S. Dobson \& K. Steinsholt (Red.), Dannelse: introduksjon til et ullent pedagogisk landskap. Trondheim: Tapir akademisk forlag. 


\title{
KAPITTEL 9
}

\section{Feltarbeid - forskande tilnærming til praksis}

\author{
Njål Vidar Traavik, Egil Eide og Gisle Heimly \\ Høgskulen på Vestlandet
}

\begin{abstract}
Using field work and undergoing field practice in junior high school in teacher education for vocational subjects is a new methodological approach to focus, content and to how student practice is organized and carried out. Our research study posed two main questions:
\end{abstract}

1. Did vocational student teachers find their field-study relevant and meaningful while in junior high school practice and in view of their future vocational teacher practice?

2. Can micro-ethnographic study as a method be used in teaching in vocational subjects for first, second and third year of senior high school?

In light of their experiences in senior high, we wanted to challenge the students to rethink and perhaps alter their approach to teaching within the framework of the junior level of high school. We also wanted the students to design and carry out a project they found challenging as well as novel for them. The selection consisted of 60 students who study to become vocational teachers. The project, including the evaluation of it, was completed in the autumn of 2016. The practice period in junior high school had a duration of two weeks.

Findings: All students considered their practice as relevant, meaningful and useful in the context of their future career as teachers. A large majority considered micro-ethnographic study as relevant for their own practice as teachers in vocational subjects in first, second and third year of senior high school. In particular, they found the subject called 'prosjekt til fordjuping' ('project for deeper learning') as very useful. Periods of placement in factories and other work situations were also found to be very useful.

Keywords: micro-ethnographic study, fieldwork, vocational teacher practice

Sitering av denne artikkelen: Traavik, N. V., Eide, E. \& Heimly, G. (2020). Feltarbeid - forskande tilnærming til praksis. I Y. T. Nordkvelle, L. Nyhus, A. Røisehagen og R. H. Røthe (Red.), Praksisnør undervisning - i praksis og teori (Kap. 9, s. 161-177). Oslo: Cappelen Damm Akademisk. https://doi.org/10.23865/ noasp.94.ch9.

Lisens: CC BY 4.0. 


\section{Introduksjon}

Den praktisk-pedagogiske utdanninga er lærarutdanning for trinn 8-13. Hausten 2013 vart det innført ny rammeplan for praktisk-pedagogisk utdanning for yrkesfag (PPU-Y) i Noreg. I rammeplanen er det eit nytt krav at minst ti dagar i praksis skal vera i ungdomsskulen.

Dette er ein ny praksisarena og samarbeidspart både for lærarutdanningsinstitusjonane, for våre yrkesfaglege lærarstudentar og for praksisskulane i ungdomstrinnet. Intensjonen med å forplikte lærarutdanningsinstitusjonar til å ha praksis i ungdomsskulen, er ifølgje rettleiinga til rammeplanen å gje studentane innsikt i overgangen mellom ungdomsskule og vidaregåande skule, og i tillegg kjennskap til arbeidslivsfaget og relevante valfag i ungdomstrinnet.

Denne artikkelen handlar om studentar ved praktisk-pedagogisk utdanning for yrkesfag (PPU-Y) sine erfaringar frå feltpraksis, og deira erfaringar knytte til bruk av feltarbeid som metode i ungdomsskulepraksisen. I studien inngår 60 yrkesfaglærarstudentar (PPU-Y) med yrkesfagleg utdanning og mangeårig yrkeserfaring frå utdanningsprogramma restaurant- og matfag, bygg- og anleggsteknikk, elektrofag, helse- og oppvekstfag, service og samferdsel, design og handverk, teknikk- og industriell produksjon og naturbruk. Studentane som deltok i denne studien, var andre kull som gjennomførte minimum 10 dagar pedagogisk praksis i ungdomstrinnet.

Alle lærarstudentar møter praksis i skular når dei skal gjennomføre praksisopplæringa. Å forske i praksis handlar om at ein forskar i eigen kultur. Cato Wadel (1991) meiner at det er å studere ein del av sin eigen røyndom. Eit grunnleggjande poeng med feltarbeidet er at PPU-studentane får høve til å erfare og tileigne seg faglege førstehandserfaringar som dei truleg ikkje får i vanleg lærarpraksis. Feltarbeid vil vera aktuelt for å kunne knytte både teori og andrehandserfaringar frå aktiv samhandling med ungdomsskuleelevane opp mot konkret røyndom. Feltarbeid gjennomført i ungdomsskulen kan bidra til at framtidige lærarar i vidaregåande skule har betre grunngjevingar for sine didaktiske val, i val av arbeidsmåtar, innhald, mål for læring og vurdering med meir.

Måtar å organisere og vidareutvikle praksisopplæringa i lærarutdanninga på har felles problemstillingar, og dei erfaringar me gjer med studentar 
som gjennomfører feltarbeid og feltpraksis i ungdomsskulen vil truleg også vera relevant, og kunne ha overføringsverdi til andre utdanningar.

Forholdet mellom teori og praksis i pedagogikkfaget og i lærarutdanningar er eit tema som ofte blir diskutert. Jensen og Traavik (2010) skriv at det er «grunn til anta at lærerstudenter opplever en praksisopplæring som ikke er i overensstemmelse med teoriundervisningen som skjer i pedagogikkfaget». Avstanden mellom teori og praksis kan også sjåast på som eit «mulighetsrom»(Kvernbekk, 2011), eit rom der det kan skje refleksjon og studentane kan utvikle handlingskompetanse.

Yrkesfaglærarstudenten i ungdomsskulepraksis som feltforskar vil oppleve å vera i eit grenseland mellom innafor og utafor, eller som Hammersley og Atkinson (1987) uttrykker det: «Feltforskeren må balansere intellektuelt mellom innforlivelse og fremmedgjorthet, mens han eller hun sosialt svever mellom venn og fremmed» (Hammersley \& Atkinson, 1987, sitert i Fuglestad, 1993, s. 19). Fuglestad (1993) diskuterer omgrepet «innforlivelse» som problematisk for feltforskaren, ut frå om han/ho identifiserer seg med eller blir identifisert som lærar eller elev. Faren for å identifisere seg med elevgruppa eller lærargruppa i sitt feltarbeid i ungdomsskulen kan då vera at ein tar bestemte grupper sitt perspektiv og dermed tolkar eller opplever desse som uproblematiske. Yrkesfaglærarstudenten som sjølv er under utdanning til å bli lærar, kan lett identifisere seg med ungdomsskulelæraren. Hammersley og Atkinson (1987) hevdar at det sentrale som feltforskar er å halde seg tilbake ved å skape sosial og intellektuell distanse til gruppene i det studerte feltet. For, seier Hammersley og Atkinson (1987, s. 109), det er i det «rommet» som denne distansen skaper, at feltforskaren sitt analytiske arbeid går føre seg. Siktemålet for feltforskaren er å ta ein marginell posisjon i feltet som kan generere kreativ innsikt (Hammersley \& Atkinson, 1987, s. 107). For å kome tett innpå ungdomsskulen som praksisarena var det mest naturleg å velje feltmetodisk tilnærming. Då oppsøkjer me det aktuelle pedagogiske feltet - ein skule, ein klasse, eit lokalsamfunn, ei spesiell gruppe - og gjer oss til deltakarar i det som der skjer. Me observerer, fører samtaler med aktørar i feltet, intervjuar og samlar inn andre typar relevant materiale (Fuglestad, 2007). Praksissituasjonar er samhandlingssituasjonar, og den metoden som eignar seg godt til å få fram data om samhandling, er deltakande observasjon (Fuglestad, 1997). 
Deltakande observasjon som metode i studiet av sosiale og kulturelle fenomen er først og fremst utvikla gjennom etnografiske studiar, og innafor antropologien som fag. Feltarbeid som deltakande observasjon byr ofte på spesielle praktiske problem. For det første kan det vera vanskeleg å få tilgang til å drive deltakande observasjon. I og med at deltakande observasjon handlar om at ein må bli med på kva personar (elevar, lærarar, rektorar, assistentar) gjer, krev dette at ein tar andre roller enn forskarrolla. Feltarbeidaren vil også bli tildelt andre roller enn forskarrolla av sine informantar (Wadel, 1991). I dei aller fleste feltarbeid er det ofte vanskeleg å planlegge i detalj kva ein skal gjera kvar dag, veke eller månad (Wadel, 1991). Gjennom bruk av feltarbeid, og feltpraksis spesielt, og kanskje på grunn av si rolle som nærast allment godkjent kjelde til meir effektiv læring, blir metoden i liten grad grunngjeve i teorien, sjølv om det er like nødvendig her som ved alle andre metodeval.

Hunnes (2007) viser til parallellar mellom opplevingsaspektet ved feltarbeid og John Dewey sin aktivitetspedagogikk. Dewey såg på læring som noko aktivt, som opplevingar, der persepsjon, kjensler og erfaringar bidrar (Vaage, 2001).

Ifølge Dewey (1929) bør hovuddelen av forskinga skje gjennom læraren si utforsking og forbetring av læringsarbeid. Det komplekse ved skulekvardagen og dei praksiserfaringar studentane møter, kan vera overveldande, og dei får difor ofte liten tid til å kunne gjera seg refleksjonar rundt alle inntrykk og erfaringar. Difor la me vekt på at studentane må vera godt førebudde og ha tid til å tenke, skrive og analysere inntrykka etterpå. Kent, Gilbertson og Hunt (1997) meiner av den grunn at forarbeid er kritisk for effektivt feltarbeid, noko som gjeld for både den praktiske gjennomføringa, og for at studentane skal oppleve effektiv læring.

I rapporten til Ludvigsenutvalet, «Fremtidens skole - Fornyelse av fag og kompetanser» (NOU 2015: 8), blir det vist til at vitskaplege metodar og tenkemåtar er ein spesielt viktig del av fagområda i framtidas skule. Den metodologiske tilnærminga til studentane sitt feltarbeid set arbeidet med feltnotat og refleksjon inn i ein aksjonsretta kontekst, der studentane saman med praksisrettleiar i ungdomsskulen prøver ut ulike aksjonar i forhold til det aktuelle fokusområdet. Intensjonen var å ha eit kritisk 
blikk på det som kom fram gjennom refleksjonar, slik at nye idear og andre måtar å gjera ting på kunne prøvast ut.

Prosjektet hadde to målsetjingar:

1. Å møte kravet om god kvalitet og relevans i yrkesfaglærarutdanninga (PPU-Y)

PPU-Y skal vera "profesjonsrettet, forsknings- og erfaringsbasert og av høy faglig kvalitet» (jamfør forskrift om rammeplan for praktiskpedagogisk utdanning for yrkesfag for trinn 8-13).

2. At me innafor ramma av PPU-Y sitt krav om ungdomsskulepraksis vil prøve ut og utvikle ein ny modell knytt til praksisopplæringa.

\section{Teoretisk ramme og metode}

Feltarbeidet eller feltpraksisen me presenterer her, kan definerast som eit mikroetnografisk studium. Postholm definerer mikroetnografi som «et nærstudium av en liten sosial enhet eller en identifiserbar aktivitet innenfor den sosiale enheten» (Postholm, 2005). Mikroetnografiske studiar er av mindre omfang og kortare tidsperioden enn makroetnografiske. Ei analyseeining i mikroetnografiske undersøkingar kan omhandle ei gruppe elevar, ein lærer, lærarteam, skuleklasse eller bedrift. Analyseeininga må vera så stor at me kan forstå korleis heilskapen og analyseeininga fungerer saman (Postholm, 2005). Dersom forskaren studerer korleis læraren utøver sin praksis i klasserommet, kan handlingane til læraren, og hans tankar og refleksjonar, berre forståast i samanheng med konteksten dei blir utført i (Postholm, 2005).

Det at studentane skulle skrive refleksjonsnotat frå refleksiv praksis, utgjer den største delen av data i dette forskingsprosjektet. Schön sitt (1983) omgrep «reflection on action» er knytt til den grunnleggjande tanken i lærarutdanninga. Tankegangen er at den som arbeider i praksisfeltet skal reflektere over sine handlingar etter at dei er gjennomført. Ved å gjera det vil studentane få eit stadig betre grunnlag for å kunne handle i praksisfeltet. I tradisjonelt feltarbeid inneber det at forskaren deltar i folk sitt daglegliv. Han «observerer det som skjer, hører på hva som blir sagt, 
stiller spørsmål - han samler med andre ord inn de data som er tilgjengelige, og som vil belyse de problemene forskningen tar opp» (Hammersley \& Atkinson, 1987). Det at forskaren er deltakande observatør kan gjera det vanskeleg for PPU-studenten å avgrensa feltforskinga som metode.

Feltarbeidet inneber eit samspel mellom personar som samtidig er både observatør for seg sjølv og objekt for den andre. Dette kompliserte møtet bør ikkje undertrykkast eller styrast av stivbeinte omgrep og metodar, dette fordi det avbryt forskaren sin dialog med sitt umedvite, og fører til forvrengingar i oppfatninga og attgjeving av «røyndommen» (Moltu, 2004).

Skrivaren si stemme i teksten skal kome fram. Etnografisk feltarbeid er meir enn metodiske teknikkar. Kultur er ikkje eit vitskapleg objekt der det gjeld å ha dei rette avdekkings- og oppteikningsteknikkane. Kulturen kan seiast å vera skapt gjennom aktiv konstruksjon av ein slags tekst (Maanen, 1988). Etnografi er dermed ikkje berre eit spørsmål om å få tilgang til feltet, men handlar også om nærleik til informantane, om å ha skarpe øyre og auge, og om ein har gode vanar når det gjeld lydbandopptak og notatteknikk og så bortetter.

Studentane skulle skrive feltnotat som ei øving i å reflektere over eiga rolle. I kritisk refleksjon refererer studentane i feltnotatet til utfordringar ved å skapa ein diskurs der dei stiller spørsmål ved praksis og prøver å sjå situasjonar på nye måtar. Fuglestad (1997) framhevar at skriving er ein viktig del av den problemløysande og skapande forskingsprosessen. Å drive samfunnsforsking er å skrive. Moltu (2004) skildrar skriveprosessen til ein etnografisk forskar å vera i ein slags indre og ytre dialog mellom felterfaring og tidlegare erfaringar. Ho ser på møtet med det framande, at det kan vera problematisk, men gjennom denne indre-ytredialogen blir det skapt kunnskap og erkjenning.

Moltu (2004) viser til Maanen (1988) sine tre ulike sjangrar som tradisjonelle for etnografisk skriving. Den mest nytta sjangeren er the realist tales. Denne stilen er ei relativt direkte, «sakleg» framstilling av den kulturen som er studert, utan noko særskilt omsyn til korleis feltarbeidaren produserer ei slik framstilling. Den andre type forteljing er confessional tales, i kontrast til den tradisjonelt realistiske og «verkelege» historia. Denne historia fokuserer meir på feltarbeidaren enn på kulturen som er studert. Forteljinga har ofte preg av at forskaren kjem med sine 
vedkjenningar om korleis arbeidet med feltet har kome til. Andre variantar er at forskaren fortel korleis ho har kome fram til dei teoretiske posisjonane, eller ein kombinasjon av desse to. Det tredje alternativet er the impressionist tales. Det er ei personleg forteljing av ulike flytande, ikkje-kronologiske moment frå feltarbeidet sett opp i ei dramatisk form, og har dermed i seg element av både realisme og skriftemål (Van Maanen, 1988, referert i Moltu 2004:9). I vår forsking har vi lagt vekt på at studentane i feltforskinga skal nytta sjangeren the realist tales.

Metodisk følgde me Cato Wadel (1991) sin modell ved eit fokusert feltarbeid (kortvarig mikroetnografisk studium):

1. Ein vektlegg eit perspektiv (teoretisk) som kan observerast i handling (sosial-samhandling)

2. Fokusert feltarbeid (mikroetnografisk studie) krev teoretisk ståstad, forståing - innsyn i tematikken - for at observasjonen ein gjer i feltet kan forståast og setjast i kategoriar for seinare analyser.

3. Metoden som eignar seg best i fokuserte feltarbeidstudiar, er deltakande observasjon.

Feltarbeidet skulle gjennomførast individuelt i løpet av seks veker (november-desember 2017):

1. Først to veker introduksjon til etnografisk metode, finne og definere teoretisk ståstad for feltarbeidet sitt fokus, og planlegge omfang av feltarbeidet

2. Deretter to veker intensiv feltpraksis

3. Etterarbeid med vurdering - skrive feltrapport

4. Vurdering av feltarbeid som metodisk tilnærming til gjennomføring, organisering, innhald og fokus i praksis

Studentane vurderte eigen feltpraksis ut frå følgjande spørsmål:

1. Har ei forskande tilnærming med bruk av feltarbeid som metode vore relevant og meiningsfullt for deg i din ungdomsskulepraksis, og som førebuing til framtidig yrkeslærargjerning? 
2. Kan feltarbeid som metode brukast i undervising i yrkesfagutdanninga på vg. 1, vg. 2 eller vg. 3 ?

Studentane skulle samle inn datamateriale både i løpet av undervisinga og i etterkant av gjennomført undervising, ved å studere dei handlingane som vart gjort. Det var viktig for studentane å finne ut kva reiskapar dei skal ta i bruk slik at materialet best mogleg kan skildre opplysningar om læringsarbeidet. Observasjon, samtalar, loggskriving og spørjeskjema var døme på slike reiskapar eller datainnsamlingsstrategiar som studentane brukte i sin feltpraksis. Målet med PPU-studentane si vurdering av feltpraksis var å gje dei ei aktiv rolle og stemme i arbeidet med utdanningskvalitet, ny kunnskap og innsikt i ei praksisnær lærarutdanning for yrkesfaglærarar.

\section{Resultat}

Me sit att med eit mangfald av data. 6o feltrapportar og 52 studentvurderingar av feltarbeid som metode i ungdomsskulepraksis, og eit breitt bilde på ungdomskulen og ungdomskulturen i dag. Feltrapportane er generelt bygde opp som kasusstudie. Kasusstudie definerer me her som ein indre studie. Når me studerer eit forskingsfelt som ein indre studie, er det det unike som skjer på dette feltet som det blir halde auge med. Ein kasusstudie tar for seg eit fenomen og fokuserer på dette. Ofte vert fleire kasus brukt for å få fram både felles mønster og variasjonar (Gudmundsdottir, 1992).

Gjennom å bruka feltarbeidsmetoden må studentane tenkje og gjera sjølv, noko som igjen har fått dei til å reflektere over lærarrolla. Studentane fekk høve til å forske i eige utdanningsfelt. Dei opplevde å kunne søke seg mot eit interessefelt, noko dei ville utforske og finne svar på. Fenomen som me innleiingsvis vil trekke fram i vår studie, viser stor breidde av kva fokus PPU-yrkesfaglærarstudenten hadde i sitt feltarbeid.

Ein gjennomgang av feltrapportane viser fokus og ulike «fenomen» som blir studerte. Døme på dette var: tilpassa opplæring i ungdomskulen, klasseleiing, reglar, inkludering, fleirkulturelle og minoritetsspråklege elevar, vurderingsordning, prøver, karakterar, nasjonale prøver, spesialundervising, arbeidslivsfaget, ulike arbeidsmåtar, IKT, iPad, PC og 
mobil i undervisings- og læringsarbeid, læremiddel, overgang ungdomsskule-vidaregåande, yrkesretting i fag og undervising, lærarsamarbeid og tverrfagleg undervising. I tillegg forska nokre studentar på ungdomskultur, forventningar til livet og/eller framtidig yrke, val av skulegang etter ungdomsskule med meir. Analyse av innhald og fokus i feltrapportane vil ikkje bli presentert her.

Me vil her presentere og diskutere PPU-studentane sine vurderingar og læringsutbyte av feltarbeidsmetoden i feltpraksis i ungdomsskulen.

Resultata er strukturert slik:

1. Har ei forskande tilnærming med bruk av feltarbeid som metode vore relevant og meiningsfullt for deg i din ungdomsskulepraksis, og som førebuing til framtidig yrkeslærargjerning?

2. Kan feltarbeid som metode brukast i undervising i yrkesfagutdanninga på vg. 1, vg. 2 eller vg. 3 ?

\section{Har ei forskande tilnærming med bruk av feltarbeid som metode vore relevant og meiningsfullt for deg i din ungdomsskulepraksis, og som førebuing til framtidige yrkeslærargjerning?}

Av dei 52 studentane som responderte om feltarbeid som metode i ungdomsskulepraksis svarte alle (100 \%) at dei opplevde feltarbeidsforma som relevant og meiningsfull. Det var eit overveldande resultat i seg sjølv. Nokre utsegner frå studentane syner oss at både relevans og det meiningsfulle er knytt til det å lære her og no, og til den framtidige yrkesrolla.

Fleire studentar kommenterte verdien av feltarbeidet som ein praktisk og meir erfaringsbasert inngangsvinkel:

"Jeg synes det har voert veldig loererikt å få arbeide med observasjon mot et forhåndsbestemt tema i skolen. Mye av det jeg har erfart i feltarbeidet kunne jeg ikke lest meg til, og samtidig tror jeg ikke jeg ville lagt merke til alt jeg observerte om jeg ikke hadde åpnet feltet gjennom teori».

Denne innsikta tyder på at studentane ser at vekselvirkninga mellom teori og praksis gror fram som gjensidige befrukta dimensjonar. Å få kjennskap gjennom nærvær og deltaking er: 
«Praksis gir bedre innsikt i teorien da man kan relatere den til ulike emner innen de tema/områder som vi berører innen PPU-utdanningen».

«Metoden feltarbeid har absolutt vort meningsfull for praksisen. Ved bruk av observasjon og samtale har jeg fått innsikt i hverdagen til elevene og loererne, fått samlet relevant data og knytte dette opp imot teori og mine/våre egne erfaringer. Fleksibiliteten med metoden har også vart hjelpsom med tanke på at du får undersøke mye på en gang, men kan plukke ut det som er relevant for din problemstilling».

Schön (1983) sitt omgrep reflection on action er knytt til grunntanken i all lærarutdanning. Den som deltar i praksisfeltet, skal reflektere over sine handlingar, i tillegg skal refleksjonar knytast opp mot aktuelle teoretiske perspektiv og forsking.

Student:

«Når ein i forkant kan bestemme seg for kva ein ønskjer å undersøke og finne ut $a v$, så kan ein vidare sjå funna opp mot forsking og teori på det aktuelle temaet. Dette at ein kan få avkrefta eller bekrefta det som ein erfarer og observerer opp mot teori og forsking, gjer at ein må reflektere og ikkje berre synse».

Studenten ovanfor viser til den analytiske tankegangen som skal sikre at han tar val som kan grunngjevast og forsvarast ut frå ein profesjonstankegang.

Fleire studentar viser til at det å ha praksis i ungdomskule har vore nyttig og relevant. Dei uttrykker at det er lenge sidan at dei sjølve var elevar i ungdomsskulen, og at det har gjort at dei har fått utfordra sine tankar rundt både elev- og lærarrolla:

"I aller høyeste grad, det er svort lenge siden jeg hadde befatning med ungdomsskolen, og praksisen har både gjort meg mer kjent med fag, elever og hvordan loererne jobber.»

«Ja. Jeg har opplevd praksisinnholdet som nyttig. Jeg har ikke vart på en ungdomsskole siden jeg selv gikk der og har både fått stadfestet og utfordret noen fordommer.»

Lærarutdanning handlar i stor grad om å trena studentane til å vera lærarar. Verdien av å observere er ein svært viktig dugleik for lærarar, og studenten uttrykker det slik: 
«Feltarbeid som metode har jeg opplevd veldig loererikt og nyttig. Det har vort en positiv erfaring av å vere observatør. Tidligere $i$ studiet har vi orientert oss om planlegging og gjennomføring av undervisning. Feltforskning i ungdomsskolen har gitt meg mer innsikt $i$ hvordan ungdomsskolen fungere, og hva som rører seg på en ungdomsskole.

Studenten trekkjer også fram at denne praksisperioden har eit nytt fokus. Fleire studentar synest at «den nye studentpraksisrolla» var både nyttig og krevjande på same tid. Det kan sjåast i samanheng med tidlegare praksisperiodar dei har gjennomført. I dei praksisperiodane har dei i stor grad hatt meir tradisjonell undervising. Det vil difor vera viktig at studentane mot slutten av studiet får møte andre erfaringar, der dei undersøkjer, reflekterer over, og får bruka andre arbeidsmåtar.

Det å også sjå elevar frå andre perspektiv som kanskje berre sosiallærarar eller sosialpedagogar får høve til i kvardagen, og anerkjenne kor viktig arbeidet med relasjonar er i skulen, var viktig for denne studenten:

«Praksisen var svoert loererik. Jeg har fätt et innblikk $i$ hvordan det er å vere loerer på en ungdomsskole og hvilke egenskaper en god loerer bør ha for å takle barn som er i overgang til ungdom, og som er full av hormoner.»

Dei brukar mange uttrykk og metaforer for å framstille denne erfaringa. Ein student skriv at fokuset på relasjonsarbeid gav ei kjensle av å få «meir kjøt på beinet». Erfaring med at fleire var i feltpraksis skapte tankar om ulike måtar å løyse oppgåva på, dei fekk nye tankar og opplevde å gå djupare i materien.

\section{Kan feltarbeid som metode brukast i undervising i yrkesfagutdan- ninga på vg. 1, vg. 2 eller vg. 3 ?}

Når det gjeld spørsmålet knytt til om feltarbeid har overføringsverdi til vidaregåande skule på vg. 1, 2 eller 3-nivå, så svarar mange studentar at dei meiner det er relevant å knytte metoden opp mot elevrolla.

Ein student uttrykker det slik:

«Ja, jeg tror denne metoden kan vare nyttig å bruke $i$ videregående. Elevene får da vare utforskende og nysgjerrige. De får også mulighet til å reflektere og tolke, noe som jeg ser på som viktig i utviklingsprosessen de er i». 
Og ein annan student ser at arbeidsmåten også kan vera aktuell å bruka meir tverrfagleg:

«Feltarbeidet og feltpraksis for studentane i PPU-utdanninga er på mange måtar eksemplarisk, då dei fleste fagområde innafor yrkesfag kan ha feltarbeid som arbeidsmåte for sine elevar i vidaregåande skule, spesielt med tanke på yrkesfagleg fordjuing. Det kan hjelpe elevane med å utforske/ forske strukturert på tema dei interesserer seg for. Men ikkje på eit sånt nivå, det må forenklast».

Nokre studentar skriv at feltarbeidsmetoden gjev elevane større rom for medverknad i eiga læring, og at arbeidsmåten kan motivere elevane i større grad:

"Jeg tror at feltarbeidsmetoden er velegnet for elever $i$ den videregående skole. Noen fordeler med denne metoden er at eleven fär medbestemmelse i egen loering ved at man velger fokusområde. Mulighetene for å velge ut fra interesser kan øke motivasjon for loeringsarbeidet. Metoden krever høy elevaktivitet, eleven fär trening $i$ å jobbe målrettet og løsningsfokusert. Samtidig gir metoden skrivetrening. Dette er nyttig både for de elevene som skal ta høyere utdanning og for de som skal videre i loerlingarbeid.»

«Det kan tenkes at elevene ville hatt et utbytte av denne metodikken i form av eierskap til oppgaven. Feltarbeidet og rapporten er på en måte elevenes egen. Ved å gå målrettet og systematisk til verks på en oppgave så blir man mer interessert og opplyst i temaet som er valgt.»

Fleire studentar viser også til at metoden vil vera aktuell i forhold til eiga framtidig lærarrolle i den vidaregåande skulen:

«Feltarbeidsmetodikken kan brukes alle steder, jeg tenker det hadde vort en stor fordel at loererne av og til har anledning til å forske på sin egen praksis. Ved å gjøre det blir den måten å observere og tenke på en del av ens egen identitet som loerer. Ogdu blir en loerar som stadig er i endring og utvikling. Det blir du ved å ha øynene åpne og observere det som skjer rundt deg. Og noterer underveis og i etterkant.»

Når me forskar i eigne erfaringar, vil truleg det tause i større grad bli uttalt. Polanyi (2000) hevdar at me veit meir enn me kan gje uttrykk for, og at kunnskap innafor dei fleste kunnskapsområde kviler på ein taus dimensjon. Det kan tyde på at studentane helst burde ha erfaring med 
den tause kunnskapsdimensjonen før dei startar å arbeide med den meir eksplisitte kunnskapen.

Studentane synest den «nye studentpraksisrolla» var både interessant og krevjande:

"Jeg har hatt ingen erfaring med feltarbeid tidligere så eg opplever dette som spennende og skjerpende. Det var arbeidskrevende, men har loert av denne praksisen»

Den forskingsdrivne arbeidsmåten har også lært studentane å skrive, dokumentere og reflektere, og det er kompetanse som er ein viktig del av lærararbeidet.

Dei opplever også at praksisperioden var annleis enn dei andre praksisperiodane dei hadde tidlegare i studiet. Studentane er tydelege på at erfaringar dei no har gjort, er av stor verdi for deira framtidige lærargjerning:

«I arbeid med feltarbeidsmetodikken har jeg lort mye. Først og fremst var jeg skeptisk til hvordan dette feltarbeidet ifeltpraksis $i$ ungdomsskolen skulle foregå og hva jeg som fremtidig yrkesfagloerer ville sitte igjen med av loeringsutbytte. Denne skepsisen er motbevist. Feltarbeidsmetodikken som summer ut $i$ et feltnotat er virkelig en god metode, først og fremst fordi en får mye refleksjon og nye perspektiv på det du undersøker, og at hypotesene du danner deg fremfor et slikt arbeid nødvendigvis ikke alltid stemmer overens. Feltmetodikken belyser virkelig at det finnes flere sider av samme sak».

\section{Diskusjon/avslutning}

Formålet med studien var å utforska studentane sine erfaringar og opplevingar med feltarbeid som arbeidsmåte, og aktivt trekke inn studentane i FoU-arbeid slik som både Forskingsmeldinga (Kunnskapsdepartementet, 2017), Ludvigsenutvalet (NOU: 2015), Nasjonale retningslinjer for praktisk-pedagogisk utdanning for yrkesfag trinn 8-13 (2018) og Rammeplanen for praktisk-pedagogisk utdanning for yrkesfag (2013) viser til.

Sentralt i drøftinga av yrkesrelevant kunnskap i lærerutdanninga står forholdet mellom teori og praksis. Nygren definerer den yrkesrelevante kunnskapen slik: «Yrkesrelevante kunnskaper er alle de kunnskapene 
som i konkret profesjonell praksis viser seg å være en ressurs i profesjonsutøverens oppgaveløsning innenfor de profesjonelle virksomheter som samfunnet til enhver tid erklærer som legitime for den aktuelle profesjonsutøverens yrkespraksis» (Nygren, 2004, s. 183).

I det kunnskapsregime som tradisjonelt eksisterer innafor lærerutdanning, er kunnskapen organisert med utgangspunkt i teori- og praksisopplæring. I veiledningsmodellen til Handal og Lauvås (2000) som har dominert lærerutdanning frå 1990-talet og fram til i dag, er ein av intensjonane å integrere handlingar som blir gjort i praksisfeltet med breiare teoretisk forståing. Me var usikre på i kor stor grad det skjer. Dette ville me undersøkje nærare i den empiriske delen av vårt prosjekt.

Yrkesfaga har tradisjonelt vore «handlingsfag», og ved å ta i bruk forskande arbeidsmåte som feltarbeid så har studentane fått eit nytt og sterkare verktøy for å kunne arbeide i skulen. Dei fleste studentane var einige om at feltarbeid, feltpraksis og arbeidskrava (feltnotatet) hadde utfordra forskaren i dei. Dei meinte at feltarbeidet var meiningsfullt og relevant for eiga læring. I refleksjonsnotatet gav studentane til kjenne at feltarbeidet hadde gjeve dei djupare innsikt i den framtidige rolla som forskande lærar og undervisar generelt, og mange svara at metoden hadde overføringsverdi, og ville vera relevant i forhold til deira arbeid som lærar i vidaregåande skule.

Studentane hadde eit tidsavgrensa møtepunkt med praksisfeltet i dette FoU-arbeidet, og i oppfølginga ynskjer me å breie forskinga utover med fleire metodar og fange fleire sider ved deira erfaringar. Dei funna som er gjort, er baserte på skriftleg evaluering av opplegget, og i tillegg studentane sine refleksjonsnotat. Likevel skildrar studentane at det er skapt eit «rom» der praksiserfaringar og «teori» frå PPU-undervisinga har støtta, men også utfordra, kvarandre.

Ved utdanningsinstitusjonar er teori i fokus, og er i stor grad organisert som forelesingar eller klasseromsundervising. Praksisopplæringa er knytt til skulen med eigne praksisrettleiarar, som har ansvar for å leggje til rette for studentane sine praksiserfaringar. I denne forskinga har søkelyset vore på praksis, på praktisk kunnskap, gjennom praktisk aktivitet i ungdomsskulepraksisen for yrkesfaglærarstudentar.

Som yrkesfaglærarutdannar fekk me med denne studien meir innsikt i og kunnskap om korleis yrkesfaglærarstudentane sine erfaringar og 
kompetanse vart brukt i ungdomstrinnet, samt at me utvikla kunnskap om korleis PPU-Y-utdanninga kan legge til rette studentane sin pedagogiske praksis gjennom samarbeid med skular på ungdomstrinnet. I tillegg fekk me utvikle kunnskap om korleis yrkesfagleg kompetanse kan gje meir praksisretta, relevant og meiningsfullt innhald i ulike fag på ungdomstrinnet.

Ved at studentane brukte metoden mikroetnografisk feltarbeid i sin praksisperiode, så viser studien at praksis var med på å utvikla yrkesfaglærarstudentane sin yrkesfaglege- og yrkesdidaktiske kompetanse. Ved å bruke feltarbeid/feltpraksis og bruke ein ny læringsarena, opplevde studentane at dei får meir progresjon i praksis, og at dei får møte andre praksiserfaringar enn i sine tidlegare praksisperiodar.

Som lærarutdannar er det heilt sentralt å utvikle ny kunnskap om det pedagogiske praksisfeltet i ungdomsskulen, noko som kan vera med på å få betre heilskap og samanheng mellom studentane sine ulike læringsarenaer i studiet, og gje dei relevante reiskapar som dei kan bruke når dei skal ut i læraryrket. Me meiner at ved å ta i bruk feltarbeid og feltpraksis så kan me i noko grad bidra til å minske spennet mellom teori og praksis i utdanninga, der me går frå lærarutdanninga si teoriundervising til praksisfeltet sitt kvardagsliv, og tilbake. Me undrar oss om feltarbeidsmetoden òg kan vera viktig tilskot $\mathrm{i}$ andre profesjonsstudiar eller disiplinstudiar.

Studentane var samde om at arbeidsmåten feltarbeid var nyttig og relevant $\mathrm{i}$ forhold til deira framtidige lærargjerning. Det vil truleg bidra til å endra deira lærarpraksisar, og til å våge å utfordra seg sjølve. Studien har også vore med på å danne grunnlag for samarbeidsprosjekt (FoUprosjekt) mellom vidaregåande skular og skular på ungdomstrinnet. Som yrkesfaglærarutdannar har me med denne studien hatt som mål å presentere feltarbeid som eit verktøy i ei forskande tilnærming til praksis i praktisk-pedagogisk utdanning for yrkesfaglærarar.

\section{Litteratur}

Beverley, A. \& Worsley, A. (2007). Learning \& teaching in social work practice.

London: Palgrave Macmillian. 
Dewey, J. (1929). Source of a science education. Cleveland, OH: Kappa delta Pi Society.

Fuglestad, O. L. (1993). Samspel og motspel. Oslo. Det Norske Samlaget.

Fuglestad, O. L. (1997). Skriveprosessen i kvalitativ forsking. I E. Fossåskaret,

O. L. Fuglestad \& T. H. Aase (Red.), Metodisk feltarbeid: produksjon og tolkning av kvalitative data (s. 237-256). Oslo: Universitetsforlaget.

Fuglestad, O. L. (2007). Tett på praksis. Innføring i pedagogisk feltforsking. Bergen: Fagbokforlaget.

Forskrift om Rammeplan for praktisk-pedagogisk utdanning for yrkesfag for trinn 8.-13. Godkjent av Kunnskapsdepartementet 18. mars 2013.

Gudmundsdottir, S. (1992). Hvordan gir teorien noering til praksis, og omvendt. Trondheim: Tapir Press.

Hammersley, M. \& Atkinson, P. (1987). Feltmetodikk. Grunnlaget for feltarbeid og feltforskning. Oslo: Ad Notam Gyldendal.

Handal, G. \& Lauvås, P. (2000). På egne vilkår. En strategi for veiledning med loerere. Oslo: Cappelen Akademisk Forlag.

Hunnes, O. R. (2007). Læringsperspektiv på ekskursjon som arbeidsmåte. Norsk Geografisk Tidsskrift - Norwegian Journal of Geography, 61(1), 38-42.

Jensen, P. I. \& Traavik, N. V. (2010). Forholdet mellom teori og praksis i pedagogikkfaget. Bedre skole, 4, 32-36.

Kent, M., Gilbertson, D. D. \& Hunt, C. O. (1997). Fieldwork in geography teaching: A critical review of the literature and approaches. Journal of Geography in Higher Education, 21(3), 313-322.

Kunnskapsdepartementet. (2017). Kultur for kvalitet i høyere utdanning (Meld. St. 16 $(2016-17))$.

Kvernbekk, T. (2011). Filosofisk om teori og praksis. Bedre skole 2, 20-25.

Lonergan, N. \& Andresen, L. W. (1988). Field-based education: Some theoretical considerations. Higher Education Research and Development, 7(1), 63-77.

Maanen, V. J. (1988). Tales of the field: On writing ethnography. Chicago: University of Chicago Press.

Moltu, B. (2004). Etnografi og kunnskapsproduksjon. Om å skrive seg ut av feltarbeidet. Norsk Antropologisk Tidsskrift, 15(4), 241-256.

Nasjonale retningslinjer for praktisk-pedagogisk utdanning for yrkesfag trinn 8-13. Vedtatt av UHR- Lærarutdanning 22. mars 2018.

NOU 2015: 8. (2015) Fremtidens skole - Fornyelse av fag og kompetanser.

Nygren, P. (2004). Handlingskompetanse. - Om profesjonelle personer. Gyldendal Norsk Forlag AS, Oslo.

Polanyi, M. (200o). Den tause dimensjonen - en innføring i taus kunnskap. Oslo: Spartacus.

Postholm, M. B. (2005). Kvalitativ metode. En innføring med fokus på fenomenologi, etnografi og kasusstudier. Oslo: Universitetsforlaget. 
Schön, D. A. (1983). The reflective practitioner. New York: Basic Books.

Schön, D. A. (2001). Den reflekterende praktiker. Hvordan profesjonelle toenker når de arbeider. Randers: Forlaget Klim.

Vaage, S. (2001). Perspektivtaking, rekonstruksjon av erfaring og kreative læreprosesser: George Herbert Mead og John Dewey om læring. I Dysthe, O. (Red), Dialog, samspel og loering (s. 129-150). Oslo: Abstrakt forlag.

Wadel, C. (1991). Feltarbeid i egen kultur - en innføring i kvalitativt orientert samfunnsforskning. Flekkefjord: SEEK A/S. 



\title{
En dags praksis: Hvordan bidra til at studentene finner sammenhengen mellom teori og den virkelige verden?
}

\author{
Randi Hojem Røthe \\ Høgskolen i Innlandet
}

\begin{abstract}
This chapter revolves a one-day practice for 200 pedagogy students at three primary schools in the municipality. The practice is completed in March when the students have studied the vocation for eight months. Lectures and seminars build up to this takeover in advance. The week before the day of practice, the students are out in the practice schools and observe the class they are going to take over and talk to the teachers at the school.

Practice reports, reflection notes and logbook notes show that no matter what we do to link theory to practice at class, it is the one day in the role of teachers at a school that seems to make the big difference. When students become responsible for a class, they behave in a completely different way than when they are responsible for teaching fellow students. At the practice school, they show up well in advance and take the responsibility they have received. The students' behaviour after the school takeover may indicate that the experiences from the real world, with associated responsibility, have given increased understanding of the vocation, which in turn contributes to increased motivation for the study programme.
\end{abstract}

Keywords: theory, practice, motivation and school takeover

\section{Introduksjon}

Her er to Ord; Det ene hedder Theori og det andet Praxis, og det er godt at have dem begge to, og det ene er ikke noget uden det andet, men det siste er dog det

Sitering av denne artikkelen: Røthe, R. H. (2020). En dags praksis: Hvordan bidra til at studentene finner sammenhengen mellom teori og den virkelige verden? I Y. T. Nordkvelle, L. Nyhus, A. Røisehagen og R. H. Røthe (Red.), Praksisncer undervisning - i praksis og teori (Kap. 10, s. 179-195). Oslo: Cappelen Damm Akademisk. https://doi.org/10.23865/noasp.94.ch1o.

Lisens: CC BY 4.o. 
beste. Og det første Ord betyder at vide Aarsagen og Grunden i et Arbeijde, men det andre betyder at gjøre Arbejdet. Ligesom nu med en Myr. For der er mange, som ved hvorledes de skal gjøre med en Myr, men gjør det galt alligevel, for de kan det ikke. Men mange kan det og ved det ikke, og saaledes kan det ogsaa blive galt, for der er mange slags Myr.

-Bjørnson, 1872, s. 56

Dette kapitlet handler om gjennomføring av en éndagspraksis på en barneskole, og om hvordan studenter og faglærere opplevde dette. Skolepraksisen er et årlig opplegg for førsteårsstudenter i pedagogikk ved høgskolen i Innlandet på Lillehammer. Pedagogikkstudiet som ble etablert tidlig på 1970-tallet, har lang erfaring med at studenter har skoleovertakelse. Ettersom antall studenter økte, ble skoleovertakelsen en frivillig aktivitet som ikke involverte hele studentkullet. Dette bestemte vi oss for å gjøre noe med.

Det er ikke lett å finne 200 praksisplasser for en dag, men via skolesjefen i kommunen fikk vi kontakt med tre skoler som ønsket et slikt samarbeid med oss. Dette var på høsten 2014, og vi gjennomførte éndagspraksis i tre år på rad på denne måten. I dette kapitlet gjennomgår jeg hva vi konkret gjorde, og hvilke erfaringer vi fikk med dagspraksisen. Det interessante for oss som et forskende lærerteam har vært å se hvor mye studentene mener de har lært av denne praksisen, og hvilke forutsetninger som må være til stede for at en slik praksis skal ha verdi.

I den didaktiske modellen vi har på førsteårsstudiet i pedagogikk er det flere komponenter som til sammen forbereder studentene på skoleovertakelsen. Studentene danner arbeidsgrupper som de arbeider i gjennom hele året når de skal levere arbeidskrav, og samspillet mellom individ og gruppe er en basisorganisering på studiet.

Vi legger også opp til at vi berører samme tema flere ganger i løpet av studieåret. Det kan ses på som et spiralprinsipp der studentene lærer stadig mer om de samme temaene. På studiet berører vi innledningsvis mange tema og begreper på overflaten for så å fordype oss mer etter hvert. Ut fra dette blir skoleovertagelsen et dypdykk i noen av begrepene og teoriene studentene har lest om. Den didaktiske relasjonsmodellen som de tidligere har brukt når de har laget kurs for sine medstudenter, får de nå et enda mer konkret forhold til. 
For å ta imot og følge opp 200 studenter deler vi dem ved studiestart i fem klasser med 40 studenter i hver klasse. En faglærer har ansvar for å følge opp en slik klasse med seminarer, veiledning og tilbakemeldinger både på gruppearbeid og individuelt arbeid gjennom hele året. På denne måten håper vi å kunne bygge gode relasjoner og å få fulgt opp den enkelte på en god måte.

Disiplinstudiet i pedagogikk er ingen profesjonsutdanning og kan være en utdanning for mange ulike jobber. Vi presiserer derfor at målet med dagspraksisen på en skole ikke er å bli lærer. Målet er å se sammenhengen mellom teori og praksis og mellom tanke og handling. Sammenhengen, eller manglende sammenheng, mellom teori og praksis i profesjonsstudier som lærerutdanning og førskolelærerutdanning er mye berørt i faglitteraturen (Unneland, 2009; Solstad, 2010; Briseid, 2011; Halmrast mfl., 2013). Samme tematikk synes imidlertid ikke å være særlig omtalt i faglitteraturen når det gjelder utdanning i disiplinfaget pedagogikk.

\section{Metodiske betraktninger}

Selve prosjektet dette kapitlet omhandler, dreier seg om implementering av en éndags praksis der studenter og faglærere er aktive deltagere. I arbeidet har jeg vært opptatt av det Tom Tiller (1999) setter som forutsetninger for aksjonsforskning: aktiv deltagelse, involvering, kritisk refleksjon og en forpliktelse til å lære av erfaringene.

For å evaluere prosessen har jeg benyttet studentenes praksisrapporter og refleksjonsnotater fra en klasse samt egne observasjoner nedtegnet i loggbok. Mine inntrykk vil i tillegg være påvirket av faglærernes teammøter der vi har delt erfaringer, reflektert og drøftet eventuelle endringer i opplegget. Vi har også hvert år hatt møte med barneskolenes rektorer for å evaluere opplegget. Som deltager i prosessen og arkitekt bak prosjektet vil jeg i utgangspunktet stille med en forforståelse preget av et ønske om å lykkes. Dette har jeg forsøkt å være bevisst på.

Det skriftlige materialet fra studentene er behandlet på følgende måte. Jeg leste først alle de 38 praksisrapportene for å skaffe meg et helhetsinntrykk. Deretter valgt jeg fire sitater som jeg synes dekker helhetsinntrykket. Etter å ha lest alle refleksjonsnotatene skrevet noen måneder senere 
fant jeg at 28 hadde reflektert over praksisen. Blant disse tekstene fant jeg to hovedkategorier. Det var Studentenes forhold til pedagogikkfaget samt Hvilke pedagogiske teorier de kjente igjen fra egen lesing og fra undervisningen ved høgskolen.

Mine observasjoner ble straks nedskrevet i loggbok. Ifølge Vedeler (2000) krever observasjon som vitenskapelig tilnærming at det er klart hva som skal observeres, hvordan det skal registreres og hvordan jeg som observatør forholder meg til det som skjer. Jeg var i denne sammenhengen bevisst på at jeg skulle observere studentenes atferd og at dette skulle registreres i loggboka. For å forstyrre så lite som mulig, var jeg ikke til stede under undervisningen. Jeg satt på lærerværelset slik at alle visste hvor de kunne finne meg.

\section{Hva er teori og hva er praksis?}

I lov om universiteter og høyskoler (Universites- og høgskoleloven, 2005) \$1-3 under institusjonenes virksomhet står det at universiteter og høyskoler skal arbeide for å fremme lovens formål ved å

a. Tilby høyere utdanning som er basert på det fremste innen forskning, faglig og kunstnerisk utviklingsarbeid og erfaringskunnskap

Her ser vi at utdanningen skal bygge på forskning, utviklingsarbeid og erfaring. Men det står ikke noe om at læringen skal skje via forskning, utviklingsarbeid og erfaringer eller praksis. Men allerede i Meld. St. 20 (2000-2001) Gjør din plikt - Krev din rett: Kvalitetsreform for høyere utdanning, (Kirke-, utdannings- og forskningsdepartementet, 2001) etterlyses aktive studenter som er en del av forskningsmiljøet ved universiteter og høyskoler og som er i kontakt med lokale aktører. I Meld. St. 16 (2016-2017) Kultur for kvalitet $i$ høyere utdanning (Kunnskapsdepartementet, 2017) skrives det i tillegg om innovasjon og entreprenørskap. Her ligger et ønske om en utdanning som er praksisnær, fremtidsrettet og nyttig for samfunnet.

Begrepet teori kan fort bli litt negativt ladet ved at det tolkes som at teorien i seg selv ikke er nyttig så lenge den ikke kan anvendes. Det er 
selvfølgelig for de fleste at et profesjonsstudium som sykepleier- eller lærerutdanning trenger praktisk opplæring og praksis for at studentene skal lære å utøve et yrke. Det er ikke like selvfølgelig for alle at et disiplinstudium trenger en type praksisinnretting for å forstå hva teorien handler om, samt trening i å bruke den teorien de lærer.

Praksis og practice beskrives ofte som en aktiv handling og som en motsats til teori (Unneland, 2009). Går vi tilbake til Aristoteles, opprettholder han todelingen mellom teori og praksis, men han fjerner motsetningsforholdet mellom dem ved å dele dem i flere begreper. Han beskriver de ulike kunnskapsformene som episteme, den teoretiske fornuft, techne, den produktive fornuft, og fronesis, den meningsgivende fornuft, der fronesis utvikles ved å handle i praxis. Aristoteles delte videre praksisbegrepet i to, poiesis og praxis, der poiesis beskrives som det å produsere noe, mens praxis står for hvordan vi lever livet. Praxis handler også om hvordan vi gjør ting og hva vi velger å gjøre (Ramirez, 1995).

Jon Frode Blichfeldt definerer praksis som måten man dyktiggjør seg på, hvordan man blir den man blir, eller det å gjøre og være virksom (Blichfeldt, 2005). Med disse ord har vi kommet til vår tid med tilhørende virkelighetsoppfatninger. Hva kan vi så lære av Aristoteles og Bjørnson? Jeg opplever at Blichfeldts forståelse av praksis som måten man dyktiggjør seg på og hvordan man blir den man blir, passer inn i Aristoteles sine begrep fronesis og praxis. Når Blichfeldt kommer til det å gjøre og vore virksom, tenker jeg at han berører Aristoteles sine begreper techne og poiesis.

Bjørnson beskriver i sitatet innledningsvis (Bjørnson, 1872) en tydelig avhengighet mellom de to begrepene theori og praxis, der Theori er Aarsagen og Grunden i et Arbeijde, eller sagt med Aristoteles sine begreper, episteme og theoria. Han beskriver praxis som å gjøre arbeidet. Dette kan i Aristoteles sitt vokabular være både techne og poiesis og fronesis og praxis så lenge vi ikke vet hva som er lagt inn av verdier i aktiviteten.

Når Blichfeldt definerer praksis som måten man dyktiggjør seg på, tenker jeg at det passer godt med den undervisning vi driver. Vi søker å dyktiggjøre studentene ved å lære dem teori og veilede dem til å ta den i bruk - de sysselsettes med studieaktiviteter og trekkes med i aktiviteter som krever fysisk og mental deltakelse. Som et disiplinstudium med mål 
om å oppøve kritisk tenkning rundt pedagogikkens rolle og plass i dagens samfunn, er vi mest opptatt av episteme og theoria. Vi som undervisere kommer ikke utenom det mer verdibaserte fronesis og praxis. Da nærmer vi oss en profesjonstankegang der det ikke bare er viktig å lære ulike aktiviteter, men der verdiene også er viktige for å kunne velge de rette aktiviteter til rett tid.

Begrepet teori vil videre i teksten bli brukt på en vid og kanskje romslig måte, ikke bare om definerte teorier, men også om andre pensumtekster som ikke nødvendigvis er teorier. Det kan for eksempel være alt fra historisk stoff til det studentene har lest om andres erfaringer. Studentene tolker også noen ganger teoribegrepet ganske langt i retning av at teorien skal gi direkte anvisning for praksis, og at de skal finne igjen teorien i praksisen. Dette trenger ikke være hverken rett eller galt, men viser studentenes måte å tenke om teoribegrepet på.

\section{Skoleovertagelse - beskrivelse av en éndags praksis}

Studieåret er delt inn i seks perioder med ulike problemstillinger. Den femte perioden går fra uke 8 til uke 12. Selve skoleovertagelsen skjer i uke 11. Uke 10 er alle studentene på besøk på sine respektive skoler for å observere den klassen de skal overta, og for å snakke med lærerne om hva som skal skje på overtagelsesdagen. Dagen før de skal ut å observere, kommer en av rektorene til høgskolen og foreleser om sine forventninger til studentene.

Etter observasjonsbesøket, i samme uke, har studentene et halvdags seminar der de planlegger sine timer, og der opplegget blir kvalitetssikret av faglærerne på høgskolen. Da har vi fra uke 8 repetert den didaktiske relasjonsmodellen og forelest om aktuelle juridiske tema, tilpasset opplæring, differensiering, vurdering, lærerrollen, kultur for læring, lærevansker og tverrfaglig samarbeid.

Uke 11 overtar vi skolene en dag. Rektor og lærere på de respektive skolene er da et annet sted og kan bruke dagen til planlegging og samarbeid. Studentene fordeles på klasser slik at de er fire til seks studenter i hver klasse. De organiserer seg slik at en student har hovedansvaret 
for hver time og disponerer de andre studentene etter behov. Hovedansvaret går på omgang. Det er opp til gruppen å la alle få prøve seg eller å la noen slippe å ha hovedansvaret. De som ikke har aktive roller, er observatører.

Etter skoleovertagelsen skriver studentene en praksisrapport i samarbeid med de studentene de har arbeidet sammen med både under planlegging og gjennomføring. Rapporten skal inneholde planlegging av opplegget ut fra den didaktiske relasjonsmodellen, gjennomføringen sett med gjennomførernes øyne, gjennomføringen sett med observatørenes øyne og evaluering av gjennomføringen. Evalueringen skal gi svar på hva som gikk bra og hvorfor det gikk bra, samt hva som kunne vært gjort annerledes og hvorfor. De skal også evaluere egen gruppe i forhold til hvordan samarbeidet har fungert. Rapporten skal hele veien vise til hvilke teorier fra pensum som er brukt, og hvorfor.

\section{Evaluering av skoleovertakelsen}

Denne type praksis ble gjennomført på samme måte i tre år hvor vi også samlet inn kvalitative data. I 2014 samlet vi data og analyserte dem systematisk. Det er 1) praksisrapporter, 2) refleksjonsnotater og 3) egne notater fra loggbok.

1. Studentenes praksisrapporter: Her er hovedfokus å knytte teori til praksis. Praksisrapporten er styrende i form og innhold, og ettersom den er skrevet rett etter skoleovertagelsen, er inntrykkene ferske, og refleksjonene om hva de har lært kan være preget av det. I tillegg er dette gruppebesvarelser der mange nyanser kan bli borte underveis. Jeg tar likevel med noen av dem her.

2. Studentenes refleksjonsnotater derimot, som de leverer som en del av sin eksamensmappe ved slutten av studieåret, opplever jeg som mer interessante i forhold til denne evalueringen. Her står de helt fritt til å velge hva de vil skrive om. Det betyr at vi her også kvantitativt kan se hvor mange som nevner skoleovertakelsen. Som faglærer med ambisjon om å ha en relasjon til studentene kan jeg ha påvirket studentenes utlegninger i positiv retning. 
3. I tillegg til studentenes refleksjonsnotater har jeg mine loggbøker. Der noterer jeg observasjoner og opplevelser etter hvert.

Praksisrapportene er levert inn med gruppenavn. For å anonymisere så mye som mulig er de her erstattet med nummer.

1. Elevene var vant til å se kortfilm om morgenen på samlingen i stillhet. I behaviorismen er de opptatt av straff og belønning for å kunne forme individet. I denne sammenhengen blir kortfilmen en form for belønning til elevene som klarer å komme seg raskt inn og komme til ro. Kortfilmen er en kjent metode for elevene, og gir dem trygge rammer, sånn at de skal oppleve dagen som normal. Dette gjorde vi for også å skape trygghet for elevene. Dette kan knyttes sammen med Maslows behovspyramide der trygghetsbehovet er på det andre stadiet etter de fysiologiske behovene.

Her ser vi en gruppe som har vært opptatt av trygghet og å gjøre det de visste at elevene var vant til å gjøre. De forteller også at de har knyttet denne praksisen til Maslows ${ }^{1}$ behovspyramide.

2. Basert på praksisdagen erfarte vi hvordan det var å praktisere forskjellige læringsteorier. Det gjorde det lettere for oss å knytte teorien opp til praksis, siden vi fikk innblikk i hvordan det fungerte.

Denne gruppen har oppdaget at læringsbegrepet kommer i spill i vekselvirkingen - ikke bare ved å gå fra teori til praksis, men også ved å gå fra praksis til teori.

3. Vi har lært at det er stor forskjell på å være pedagog i praksis i forhold til det vi lærer i teorien. Med tanke på at det finnes ulike barn opplevde vi at tilpasset opplæring er noe som burde bli satt mer i fokus fra tidlig alder.

Denne gruppen ser ut til å ha erfart at det var stor forskjell på det de opplevde i praksis i forhold til det de hadde lest i forkant. Dette knytter de til tilpasset opplæring der det virker som om de har erfart behovet for tilpasset opplæring slik det ytrer seg i konteksten.

1 Maslow, Piaget, Dewey og Vygotsky er navn og begreper som fort får en hverdagslig posisjon i studentenes ordbruk. Jeg sparer leseren for referanser på disse. 
4. Teori fra skolebenken er bra å ha som grunnmur, men det er i praksis med elever man virkelig lærer. Gjennom arbeidet på skolen fikk vi se ulike situasjoner som vi kunne koble opp til ulike læringsteorier. Den læringsteorien vi følte vi så mest igjen var den sosiokulturelle læringsteorien. Vi så at elevene samarbeidet, gav hverandre tips og backet opp hverandre.

Dette siste sitatet fra praksisrapportene uttrykker at de har lært noe i praksis. De beskriver teorien som grunnmuren. Selve huset eller læringen kommer ifølge denne gruppen ikke uten praksis. I tillegg har de beskrevet at den læringsteorien de observerte mest på praksisdagen, var den sosiokulturelle læringsteorien.

Refleksjonsnotatene viser at skoleovertakelsen er noe studentene setter pris på. 28 av 38 refleksjoner som jeg leste det siste året, inneholdt positive tilbakemeldinger om skoleovertakelsen. Studentene beskriver her den læringsprosessen de gikk gjennom ved å reflektere over teori og praksis.

5. Noe jeg vil trekke fram som et høydepunkt gjennom studieåret er skoleovertagelsen i vårsemesteret. Den var nok også på mange måter et vendepunkt i holdningen min til pedagogikkfaget. Denne dagen og de erfaringene jeg gjorde meg her føler jeg gjorde at jeg fikk større innsikt i faget, da sammenhengen mellom teori og praksis ble tydelig på en helt annen måte enn bare gjennom arbeid på egenhånd.

Dette sitatet forteller om en student som opplever et vendepunkt når det gjelder pedagogikken. Han eller hun opplever i tillegg å få ny innsikt.

6. For mitt vedkommende var det imidlertid særdeles lærerikt å være i praksis på en skole. Dette gjorde at vi hadde muligheten til å prøve ut teorien i praksis, samtidig som vi også kunne bruke opplevelser fra praksis og knytte dette opp mot teori i etterkant.

Denne studenten peker på at det ikke bare var fint å kunne knytte den teorien de allerede hadde lært før til praksisen, men at det også i etterkant var fint å knytte ny teori til den praksis de hadde erfart. Her ser vi hvordan denne studenten beskriver hvordan teorien kan påvirke praksis og omvendt. 
7. I vinter hadde vi en praksisdag på en barneskole. Dagen var til for at studentene skulle erfare sammenheng mellom teori og praksis. Jeg opplevde praksisdagen som svært nyttig. Dette var mye på grunnlag av at vi underviste klassen etter forskjellige læringsteorier. Det var i hovedsak sosiokulturell og behavioristisk læringsteori. Det var interessant å se hvordan teoriene fungerte i praksis, og jeg opplever at mye av det vi lærer i studiet, stemmer med den praksis som foregår i skolen. Min erfaring er at et slikt opplegg er gull verdt for studentene.

Vi ser i sitat nummer sju at vedkommende uttrykker forbauselse over at det de har lært i teorien, ser ut til å stemme i praksis. Hun eller han går så langt som å skrive at en slik praksis er gull verdt for studentene.

8. Jeg har også fått en større kunnskap om tilpasset opplæring, vært på skoleovertakelse og sett hvor viktig det er å tilpasse opplæringen til hver enkelt elev. Det er ikke alle som lærer likt. Jeg føler jeg har lært mye om ulike teorier som jeg aldri hadde hørt noe om. Etter skoleovertakelsen har jeg sett hvor viktige disse teoriene er i dagens skole. Mye viktigere enn jeg trodde før skoleovertakelsen.

Her møter vi en student som tydeligvis har lest teorien uten å ha noen tro på at den kunne brukes til noe. Hun eller han uttrykker en overraskelse over pedagogikkens rolle og betydning i dagens samfunn.

9. En annen viktig erfaring var skoleovertagelsen. Her fikk vi oppleve pedagogikk i praksis og her fikk vi virkelig bruk for de ulike teoriene til Vygotsky, Dewey, Piaget og Locke. Jeg fikk virkelig oppleve at barneskolen brukte Vygotsky sin teori om den sosiokulturelle teori. Her hadde de veldig stort fokus på at barna skulle lære seg å jobbe sammen i grupper og der de skulle bruke språk som verktøy for å diskutere seg fram til et svar. Man kunne også se at teorien til Dewey om learning by doing og teorien om den mer kompetente andre kom godt fram når elevene arbeidet i grupper. Jeg må si jeg ble positivt overrasket på skoleovertakelsesdagen når jeg fikk se hvor stor rolle pedagogikken har i dagens skole og samfunn.

I dette sitatet møter vi enda en student som er overrasket over pedagogikkens rolle og at den er så viktig både i skolen og i samfunnet. 
Disse fem første sitatene opplever jeg i tillegg til å si noe om selve pedagogikkfaget, også sier noe om studentene selv og deres forhold til faget. De neste sitatene vil i større grad si noe om hvilke teorier innenfor pedagogikkfaget de har fått testet ut.

10. Noe av det viktigste for min læring under dette året har vært skoleovertagelsen vi hadde i mars. Besøket på skolen ga meg mulighet til å kunne knytte sammen den teorien jeg har lært med praksis. Dette opplevde jeg som nyttig i forhold til å kunne skille mellom ulike læringsteorier, og å kunne se hvordan disse fungerte i praksis. Jeg fikk se hvordan de vi underviste responderte ulikt på bruk av konstruktivistisk og sosiokulturell læringsteori. Jeg lærte at noen elever jobber best med oppgaver alene hvor de kan jobbe på sin måte og kan konstruere sin egen kunnskap. Andre elever opplevde jeg hadde best nytte av å jobbe med oppgaver i samarbeid med andre.

Dette sitatet viser en student som har oppdaget at ulike elever lærer på ulike måter, samtidig som hun eller han viser til ulike læringsteorier.

11. Etter skoleovertakelsen og generelt etter å ha tilnærmet meg pensum, har jeg fått forståelse for at tilpasset opplæring handler om mer enn bare elevens evner. Det er viktig å se på flere faktorer som kulturell bakgrunn, følelser og utvikling når undervisningen skal tilpasses de ulike elevene. Jeg har også lært at tilpasset opplæring ikke bare gjelder for de svakere elevene, men også for de sterke elevene.

I dette sitatet ser vi en student som i utgangspunktet har erfaring med at det kun er de elevene som sliter faglig, som trenger tilpasset opplæring. Nå har han eller hun oppdaget at det kan være andre årsaker til behov for tilpasning, og at flinke elever også trenger tilpasning.

12. Denne dagen ble brukt på en veldig god måte til å få satt teori i praksis. Det var lærerikt å se de individuelle forskjellene hos 6 . klassingene, siden dette stemte bra med Piagets teori om utviklingsstadiene (Imsen, 2014).

Dette sitatet viser en student som har fått utvidet forståelse av Piagets utviklingsstadier. Studentene viser i flere andre sitater hvordan Maslow og Skinner sine teorier kommer til syne. 
13. Skoleovertagelsen er helt klart det programområdet jeg sitter igjen med mest læring. Det å få teste ut det vi har lært gjennom året i praksis, var veldig lærerikt. Det å sette seg inn i rollen som lærer var litt uvant i starten. Det fikk meg til å tenke at det er ganske lett å være elev. (...) Ut fra dette kan man også se at konstruktivisten John Dewey har rett i sin teori: Learning by doing - and reflection. Man lærer av å prøve, og man lærer av å feile, og reflekterer man over det etterpå, vil læringsutbyttet bli stort.

En oppsummering fra disse sitatene er at studentene er positive til skoleovertagelsen. De beskriver den som det som har gitt dem mest læring, vært høydepunktet i semesteret og gull verdt for studentene. Når de i tillegg nevner teori de har fått prøvd ut, bekrefter de at det har vært lærerikt. Det at noen av studentene er overrasket over at pedagogikken er viktig i skolen og samfunnet, og at teorien stemmer med praksis, forteller meg at en slik praksis er viktig for å knytte teorien til praksis og praksis til teorien. Mine refleksjoner går videre til Dewey og hans kjente uttrykk learning by doing and reflection. Det som kanskje ikke er like kjent for alle, er at han i tillegg sa at det vi skal lære må ha en betydning for oss. Når studentene uttrykker overraskelse over å erfare at det de har lært av pedagogikk er nyttig, tenker jeg at de nå har lært fordi pedagogikken har fått en betydning for dem.

I tillegg til studentenes refleksjoner har jeg mine notater fra loggboka:

15.03.17 Det er skoleovertagelse. Studentene har overtatt skolen for en dag. Jeg sitter på lærerværelset. Jeg ser noen studenter med gule vester som fyker ut for å ha inspeksjon. Noen kommer på lærerværelset for å spise. Andre forbereder undervisning, mens noen er i gang.

Min refleksjon i ettertid er at det er flott å se hvordan de tar ansvar når de får det. Jeg spør meg selv om de får for lite ansvar i det daglige som student.

16.03.17 Alle mine 7 grupper har veiledning på praksisrapporten sin. Det er rene oppturen for meg. De kommer og er veldig nysgjerrige på hvilke læringsteorier de har brukt. Jeg opplever at de er i ulikevekts-modellen til Piaget og fulle av indre motivasjon. 
Jeg er ikke vant til at alle stiller opp på veiledning slik de gjorde denne dagen. Jeg opplevde dem mer motivert enn tidligere. Det hører med til historien at gruppene oppsøkte meg for å diskutere rapporten flere ganger.

29.03.17 2 grupper har sendt inn nesten ferdige A-6 til veiledning. Det er mye å lese, men det er positivt at de er så ivrige. Tre grupper har bedt om og avtalt tid for veiledning før de får tilbudet i morgen.

Det faktum at jeg noterer dette, viser tydelig at jeg er overrasket. Jeg opplever at motivasjonen fra skoleovertakelsen nå føres videre til det neste arbeidskravet. Hva har det med sammenhengen mellom teori og praksis å gjøre? Jeg tenker at den økte forstålsen for faget, som det ser ut til at studentene får gjennom skoleovertakelsen, gir dem en indre motivasjon til å arbeide videre. Studentene forteller altså om at en dags praksis er et viktig vendepunkt i deres opplevelse av faget - én dag med autentiske situasjoner med virkelige barn i den virkelige skolen, og vi stopper opp og tenker: Kunne vi gjort dette hele tiden?

\section{Hvordan bidra til at studentene finner sammenhengen mellom teori og praksis?}

Praksisrapporter, refleksjonsnotater og loggboknotater viser at til tross for at vi som forelesere, seminarledere og veiledere i den daglige undervisningen på høgskolen hele tiden forsøker å knytte teori til praksis og praksis til teori, så er det den ene dagen ute i det virkelige liv, som lærer på en skole, som ser ut til å gjøre den store forskjellen. Slik Saugstad (2015) beskriver Aristoteles sin lære, kaster den lys over denne erfaringen. Aristoteles deler kunnskapen opp i en teoretisk tilskuerkunnskap og en praktisk deltagerkunnskap. Han mener at den praktiske kunnskap læres i det praktiske liv i autentiske situasjoner, og at dette er et læringsrom som skolen ikke kan tilby. Studentenes refleksjonsnotater er tydelige på at skoleovertagelsen er viktig for deres læring. Som en student skriver, så er den gull verdt. Det kan handle om mer enn hva de har lært. Det kan også handle om motivasjon slik vi ser i mine loggførte notater.

Et kritisk spørsmål å stille kan være hvor dyp og reell den kompetansen studentene tilegner seg er. Jeg tolker studentenes refleksjoner som at 
de ut fra sine forutsetninger og opplevelser er klare på at de har lært mye. Når jeg leser studentenes neste arbeidskrav - som ikke bød på tilsvarende møte med livet utenfor høgskolen, opplever jeg ikke at kompetansehevingen har gjort noe kvantesprang. Det jeg imidlertid registrerer som en tydelig endring, er den økte motivasjonen for faget, og det kan i sin tur gi økt kompetanse. Spørsmålet er om ytterligere praksisnære opplevelser ville løftet flere studenter høyere i sin forstålse av og innlevelse i faget.

Når jeg skal svare på hvordan vi kan bidra til at studentene skal finne sammenhengen mellom teori og praksis, tenker jeg at alt vi gjør gjennom hele studieåret er med på å bidra til at skoleovertakelsen oppleves som positiv for studentene - noe det er skapt forventninger om og motivasjon for. Det kan for eksempel handle om at en planlagt læringsprosess i forkant av skoleovertagelsen er med på å gjøre at studentene lykkes. Dette kan igjen knyttes til mestringsmotivasjon slik jeg har antydet i min logg. Det kan også handle om at våre krav om en rapport der alt skal dokumenteres med observasjoner, erfaringer og teori, bidrar til innsikt i hvordan teori og praksis henger i hop, for mange av studentene. De skriver seg gjennom stoffet til læring, slik en av pensumbøkene også foreslår (Dysthe, Hoel \& Hertzberg, 2010). Dette kan også gi en følelse av å lykkes. Noen av studentene beskriver forbauselsen over å oppdage at det de leser om pedagogikk i pensum ikke bare stemmer med virkeligheten, det er også viktig.

Men vi kommer ikke utenom at det å komme ut i det virkelige liv og det å få ansvar gjør noe med studentene og deres motivasjon. De har planlagt undervisning og gjennomført opplegg for medstudenter på høgskolen der jeg hadde ansvaret og satt som observatør. Det blir tydeligvis tolket som at de er på skolen, og at det er jeg som har ansvaret. Det jeg ser når studentene er ute på en barneskole i kommunen og får ansvaret for en klasse, da går de til verket på en helt annen måte. De møter opp i god tid før god tid og tar det ansvaret de har fătt. Jeg ser at noen er rød i toppen av spenning. Andre kommer til lærerværelset og er helt utslitt etter å ha hatt én time. Da har alle sanser vært brukt, muskler, pusteapparat og oppmerksomhet har vært i helspenn i tre kvarter, på en helt annen måte enn de får oppleve på høgskolen. De vokser øyensynlig med oppgaven når de får ansvar og blir en man må stole på. 
Går vi tilbake til de innledende betraktningene rundt teori og praksis, ser vi at Aristoteles beskriver at theoria handler om innsikt og analyse, poiesis handler om produksjon, og praxis handler om sosialetisk samhandling (Saugstad, 2007). Gjennomføring av denne hurtig-praksisen bygger på forelesninger med theoria fra studiestart. Eller som en av gruppene skrev i sin praksisrapport: «Teori fra skolebenken er bra å ha som grunnmur, men det er i praksis med elever man virkelig lærer.» Puslespillet man bygger opp med relativt løse mentale skjema, blir med andre ord et meningsfylt bilde når elementene fra en praksisopplevelse gir dem en rikere kontekst.

Bjørnstjerne Bjørnson, via Øyvind, uttrykker at det er godt å ha både teori og praksis, for det ene er ikke noe uten det andre. Han starter med å likestille de to begrepene, men sier videre at praksis er best, for det hjelper ikke å kunne teori hvis man ikke kan bruke den i praksis. Det jeg tolker ut fra noen av sitatene fra refleksjonsnotatene, er at studentene ikke har hatt noe forhold til teorien. De har lært seg noe som de trodde ikke hadde noe med virkeligheten å gjøre. En student skriver «... jeg opplever at mye av det vi lærer i studiet, stemmer med den praksis som foregår i skolen.» En annen student skriver: «Jeg må si jeg ble positivt overrasket på skoleovertakelsesdagen når jeg fikk se hvor stor rolle pedagogikken har i dagens skole og samfunn.»

Jeg viste til Blichfeldt, som definerte praksis som måten man dyktiggjør seg på, og hvordan man blir den man blir. Min refleksjon i forhold til denne definisjonen er at den kommer fra en mann som i et langt liv har drevet med praksisnær forskning i tillegg til å ta sine teoretiske grader. Han har via praksis dyktiggjort seg. Våre studenter, som går på et disiplinstudium, uttrykker i sine refleksjonsnotater at de trenger praksis for å dyktiggjøre seg. Så hvordan kan vi hjelpe studenter til å finne dyp mening når høgskolen er innrettet som den er?

Mitt svar på spørsmålet om hvordan vi kan bidra til å knytte teori til praksis, er at det er viktig for oss som undervisere å tenke sammenheng mellom teori og praksis hele tiden. Selv om vi strever for å fortelle, demonstrere, vise, diskutere, observere og engasjere, kommer vi til kort. En trist konklusjon kan være at uansett hva vi gjør i høgskolens lokaler, så ser det ikke ut til å være tilstrekkelig nær den praksis vi 
kan oppleve utenfor. En mer positiv fortolkning er at det teoritilfang vi presenterer, gir mange studenter den satsplanke de trenger for å lære disse komplekse sammenhengene. Min erfaring er at én dag ute i den virkelige verden kan være et godt bidrag i prosessen med å dyktiggjøre seg, under forutsetning av at vi krever dokumentasjon der de må vise til sammenhengen mellom praxis og theoria. Eller som Aristoteles skrev $\operatorname{det}($ fritt oversatt):

Lærebøker i medisin eller jus har ingen verdi før den som skal lære har fått erfaring med å kunne tolke en gitt praktisk situasjon. Først med en slik erfaring blir den som skal lære i stand til å vurdere hvilken generell teori fra læreboka som passer best i den konkrete situasjonen. (Aristotle 1994 s. 641)

\section{Litteraturliste}

Aristotle. (1994). Nicomachean ethics (Loeb Classical Library edition). Cambridge, MA: Harvard University Press.

Bjørnson, B. (1872). Forteellinger. København: Den Gyldendalske Boghandel.

Blichfeldt, J. F. (2005). Praksisberetning fra en «kunnskapsarbeider»: Tanker om tro og tvil. I K. Fossestøl \& O. Eikeland (Red.), Nytt arbeidsliv - nye former for kunnskapsproduksjon (s. 233-259). (Vol. 12, Arbeidsforskningsinstituttets skriftserie (trykt utg.)). Oslo: Arbeidsforskningsinstituttet.

Briseid, L. (2011). Fra teori til praksis - med levende historie; erfaringer fra et tverrfaglig prosjekt som kobler sammen fag og praktisk-estetiske virkemidler i lærerstudenters øvingspraksis. Norsk pedagogisk tidsskrift, 95(3), 198-215.

Dysthe, O., Hoel, T. \& Hertzberg, F. (2010). Skrive for å loere: Skriving i høyere utdanning (2. utg.). Oslo: Abstrakt.

Halmrast, G. S., Taarud, R. \& Østerås, B. (2013). Bruk av praksisfortellinger for å skape sammenheng mellom praksis og teori i førskolelærerutdanningen. Norsk pedagogisk tidsskrift $97(1), 70-80$.

Kirke-, utdannings- og forskningsdepartementet. (2001). Gjør din plikt - krev din rett: Kvalitetsreform av høyere utdanning: Tilråding fra Kirke-, utdannings- og forskningsdepartementet av 9. mars 2001, godkjent i statsråd samme dag (Vol. Nr 27 (2000-2001), trykt utg.)). Oslo: Departementet.

Kunnskapsdepartementet. (2017). Kultur for kvalitet i høyere utdanning (Vol. 16 (2016-2017), trykt utg.)). Oslo: Departementenes sikkerhets- og serviceorganisasjon. 
Imsen, G. (2014). Elevens verden. Innføring i pedagogisk psykologi. 5. utgave. Oslo: Universitetsforlaget.

Ramirez, J. (1995). Skapande mening. En begreppsgenealogisk undersökning av rationalitet, vetenskap og planering. Nordiska Instituttet för samhällsplanering. Avhandling 13:2. Stockholm: Nordplan.

Saugstad, T. (2007). Om viden og kunnen - pædagogisk sett. I P. Ø. Andersen, L. J. Muschinsky, T. Ellegaard \& S. J. Hansen (Red.), Klassisk og moderne pæedagogisk teori. København: Hans Reitzels forlag.

Saugstad, T. (2015). Pædagogikken mellem det bureaukratiske og det postmoderne praksisfelt. Nordic Studies in Education, 35(2), 87-101.

Solstad, A. G. (2010). Praksisnær teori og teorinær praksis - den nødvendige relasjonen. Norsk pedagogisk tidsskrift, 94(3), 203-218.

Tiller, T. (1999). Aksjonsloering: Forskende partnerskap i skolen. Kristiansand: Høyskoleforlaget.

Universitets- og høyskoleloven (2005). Lov om universiteter og høyskoler LOV2005-04-01-15. Hentet fra https://lovdata.no/dokument/NL/lov/2005-04-01-15

Unneland, A. K. R. (2009). Mind the gap! - Om den praktiske og teoretiske kunnskap i lærerutdanningen. Norsk pedagogisk tidsskrift, 93(5), 316-327.

Vedeler, L. (2000). Observasjonsforskning i pedagogiske fag. En innføring i bruk av metoder. Oslo: Gyldendal Akademisk. 



\title{
KAPITTEL 11
}

\section{Praksisnær undervisning - en forutsetning for innovasjon og entreprenørskap!}

\author{
Ingrid Tvete \\ Høgskolen i Innlandet
}

\begin{abstract}
In this chapter I examine the importance of the concepts of entrepreneurship and innovation in an educational context. The aim of the chapter is to show that entrepreneurship and innovation are not only political superlatives, but also useful approaches to a more practice-oriented teaching in higher education. Practice-oriented teaching is teaching with a clear applied orientation, and I examine how entrepreneurial perspectives and forms of teaching can contribute to this applied orientation through examples, among other things, from the innovation methods we find in 'Liberating Structures'. The intention of the examples is to demonstrate that entrepreneurship and innovation are useful and simple tools when it comes to facilitating teaching situations where the students must connect theory and practice.

Boyer and Knorr-Cetina's thoughts on knowledge are briefly referenced to support the notion that the students need expertise in how social structures and knowledge development influence each other reciprocally. This is seen in the context of political governance documents and especially Nordic literature on entrepreneurship. Entrepreneurial teaching methods and practice-oriented teaching are then linked to a situational and contextual learning perspective, and I argue that entrepreneurship and innovation are inextricably linked to practice-oriented teaching. I conclude that through entrepreneurship and innovation in higher education we can facilitate a practice-oriented learning where the student learns situationally, without necessarily being in a practical situation.
\end{abstract}

Keywords: entrepreneurship, innovation, entrepreneurship education, practice oriented learning, public policy, situated learning, higher education, teaching

\footnotetext{
Sitering av denne artikkelen: Tvete, I. (2020). Praksisnær undervisning - en forutsetning for innovasjon og entreprenørskap! I Y. T. Nordkvelle, L. Nyhus, A. Røisehagen og R. H. Røthe (Red.), Praksisnoer undervisning - i praksis og teori (Kap. 11, s. 197-217). Oslo: Cappelen Damm Akademisk. https://doi.org/10.23865/ noasp.94.ch11.

Lisens: CC BY 4.0.
} 


\section{Introduksjon}

Politiske styringsdokument spår at framtidens samfunn vil kreve at vi legger til rette for læreprosesser hvor det handles kreativt, innovativt og skapende. Satsing på entreprenørskap i hele utdanningssystemet trekkes fram som svaret på hvordan vi kan få til slike læreprosesser. Entreprenørskapsutdanning skal fremme kompetanse og refleksjon om hva entreprenørskap og entreprenøriell læring er, demonstrere og utvikle innovative og entreprenørielle arbeidsformer og bidra til systematisk erfaringsdeling av undervisningsformer som fremmer anvendt kompetanse om innovasjon og nyskapning (Kunnskapsdepartementet, 2009; Kunnskapsdepartementet, 2004; Kvangarsnes, Håvold \& Helgesen, 2016; Kunnskapsdepartementet, 2017; Åmo, 2012).

Entreprenørskapsutdanning kan være utdanning både for, om og gjennom entreprenørskap. Det ligger derfor tilsynelatende et stort tolkningsrom i de forventningene som universitets- og høgskolesektoren møter, og det er kanskje heller ikke klare forhold rundt hva som skal leveres. Grunnlaget for tilnærmingen i artikkelen er en bred forståelse av entreprenørskapsbegrepet med fokus på hvordan vi i høgere utdanning kan legge til rette for gode læringsprosesser som fremmer entreprenørskap og innovasjon. Jeg ønsker å se på om forståelsen og dermed også operasjonaliseringen av begrepene «innovasjon» og «entreprenørskap» kan være en inngangsport til å realisere målet om mer praksisnær undervisning i høgere utdanning. I artikkelen vil jeg argumentere for at entreprenørskap og innovasjon er uløselig knyttet til praksisnær undervisning nettopp fordi entreprenørskap og innovasjon må dannes og utvikles i situasjoner som utfordrer den tradisjonelle klasseromspraksisen.

Utgangspunktet for entreprenørskapssatsingen er en antagelse om at økt fokus på entreprenørskap og innovasjon i høgere utdanning gir en merverdi for både studentenes læreprosess og arbeids- og samfunnsliv for øvrig - lik den tenkningen vi finner i Boyers scholarshipstenkning, jf. kapitlet fra Nordkvelle. Denne tenkningen har praksisnærhet som premiss, og jeg ønsker også å se på hva slags praksisnær undervisning innovasjons- og entreprenørskapstenkningen forutsetter. Det er derfor nødvendig å gå inn på hva entreprenørskaps- og innovasjonsarbeid i 
utdanningssystemet er, og hvilken tilnærming lærere, utdanningsledere og andre utdanningsaktører knyttet til høgere utdanning bør ha for å nå disse målene.

Stoltenberg-regjeringens (2005-2013) mål om entreprenørskapsutdanning handlet om å styrke kvaliteten på og omfanget av entreprenørskapsutdanning på alle nivåer og i alle disipliner i utdanning, jf. «Regjeringens handlingsplan; Entreprenørskap i utdanning - fra grunnskole til høyere utdanning fra 2009 til 2014» (Kunnskapsdepartementet, Nærings- og handelsdepartementet og Kommunal- og regionaldepartementet 2009). Solberg-regjeringen fulgte opp satsingen, blant annet gjennom Meld. St. 16 (2016-2017) «Kultur for kvalitet i høgere utdanning», hvor innovasjon og mer praksisnær undervisning trekkes fram. Dagens landskap for universitets- og høgskolesektoren viser at det stadig satses på innovasjon og entreprenørskap, men oppdraget tolkes imidlertid forskjellig mellom institusjoner og mellom fagområder.

Universitets- og høgskolektorens eget råd fremhever at «... norske universiteter og høyskoler har et viktig ansvar for å bidra til innovasjon i norske virksomheter og i offentlig sektor. Innovasjon er en av universitets- og høgskolesektorens fire kjerneoppgaver, ved siden av forskning, utdanning og formidling» (Universitets- og høgskolerådet u.å). Denne tenkningen er i stor grad sammenfallende med Boyers inndeling i fire scolarships, jf. innledningskapitlet til Nordkvelle, samtidig som Boyer ikke framhever innovasjon som en egen form for scolarship. Boyer argumenterte for at tradisjonell forskning må utvides og gjøres mer fleksibel for å inkludere nye sosiale og miljømessige utfordringer utover universiteter og også virkeligheten i dagens liv. Vi kan spesielt skjele til «application», eller applikasjon, hvor vi ser at Boyer argumenterer for at høgere utdanning må stimulere til et samfunnsengasjement utenfor universitet og høgskoler gjennom innovasjon og kunnskapsutvikling for framtida.

Det ligger i utdanningssystemets natur at det til enhver tid må drive kvalitetsutvikling. For eksempel peker Kommunenes Sentralforbund, KS, på at framtidas samfunns- og arbeidsliv vil ha andre behov enn gårsdagen (Kommunenes sentralforbund u.å.). Dette synes åpenbart og nærmest unødvendig å påpeke, men alle endringer krever tilpasninger, 
og utdanningssystemet handler i stor grad om en tilpasning til samfunnet. Dette fordrer at de som arbeider i utdanningsløpet har forståelse for, og kompetanse i, prosesser rundt innovasjonsarbeid. Samtidig er UH-sektorens tilpasninger til samfunnet også noe som diskuteres. For eksempel viser Bjørn Willy Åmo ved Nord universitetet, Bodø, til et skifte i tolkningen av hva som er formålet med høyere utdanning (2012). Tradisjonelt har universitetene utviklet ny kunnskap gjennom forskning, og så delt kunnskapen gjennom undervisningen; en klassisk tilnærming til forskningsbasert undervisning. Skiftet inntrer når det kommer forventninger om at universitet og høgskoler skal inngå «... som en vital komponent i samfunnets innovasjonssystem» (Åmo, 2012, s. 13). I denne komponenten ligger det forventninger til en mer aktiv involvering av hvordan kunnskap kan bidra til å utvikle lokalt og nasjonalt næringsliv og samfunnsliv. Dette er i tråd med såkalt Mode 2-tenkning om kunnskapsutvikling, hvor man framhever at kunnskap skapes i samvirke med andre. Dette vil nødvendigvis kreve en annen tilnærming til både hvordan kunnskap genereres, og til hvordan kunnskap og forskning deles, for eksempel i undervisningssituasjoner, og hvordan det formidles. Skiftet innebærer et nærmere samarbeid med lokalsamfunnets og arbeidslivets aktører. I noen fagområder er dette kjent terreng; profesjonsstudier som sykepleie, lærerutdanning, sosialt arbeid og vernepleie er eksempler på studietilbud hvor fagansatte i stor grad rekrutteres fra praksisfeltet, og hvor samarbeidet med arbeidslivet er tett og nokså kontinuerlig. Andre fagområder er mer distanserte fra praksis, og i denne artikkelen vil jeg benytte eksempler fra en disiplinutdanning i pedagogikk.

For å bedre kunne forstå hva som er målet med satsingen på entreprenørskap og innovasjon i høgere utdanning, vil jeg fortsette artikkelen med å se nærmere på både innholdet og forholdet mellom disse begrepene. Deretter vil jeg trekke fram noen perspektiv på hva slags implikasjoner innovasjons- og entreprenørskapstenkningen har for undervisning og læring i høgere utdanning. Her vil jeg særlig vise til praksisnær undervisning som en nødvendig tilnærming, og jeg diskuterer hvordan læringssynet i praksisnær undervisning er sammenfallende med læringssynet i entreprenørskapssatsingen. 


\section{Forholdet mellom entreprenørskap og innovasjon - Hvordan oppstår innovasjoner og entreprenørskap?}

Hver høst innleder jeg en forelesningsrekke om entreprenørskap med å nettopp spørre studentene om hva entreprenørskap er. Vi begynner med en øvelse hvor jeg skriver «entreprenørskap» på tavla. Studentene blir bedt om å notere ned hva de assosierer med begrepet - først individuelt, så i par. Vi samler så assosiasjonene på tavla eller på veggaviser i en plenumsøkt. Erfaringene mine fra denne oppgaven viser at studentenes assosiasjoner oftest peker mot selve entreprenøren, og det er individet bak entreprenørskapet som nevnes. Siden 2010 har det vært få endringer: Bill Gates, Steve Jobs, Petter Stordalen og Olav Thon. Noen husker Røkke, og RIMI-Hagen blir stadig vekk assosiert med en butikkjede som ikke eksisterer lenger. Fellestrekk i forklaringene jeg henter, er at entreprenørskap i større grad forbindes med menn enn med kvinner, det er videre fokus på gründerskap og gründere og det fokuseres på oppfinnelser og nyskaping.

Individperspektivet, slik studentene ser ut til å assosiere med entreprenørskap, finner vi også igjen i forståelser av innovasjon. Osborne og Brown (2011) viser til at den tradisjonelle modellen eller oppfattelsen av innovasjon i offentlig sektor er forankret i bildet av en individuell aktør som kilden til innovasjonen. Her kommer begrepet «hero innovator» inn, en entreprenør som innoverer. En slik forståelse er støttet av Drucker (1985) og Roberts og King (1996). Oppfattelsen er dermed sammenfallende med hvordan mine studenter betrakter entreprenøren. Roberts og King utviklet bildet av den offentlige entreprenøren som målrettet, arbeidssom, risikovillig, selvsikker og dreven i politisk lobbyvirksomhet (Osborne \& Brown, 2011). Hvis vi ser på den norske strategien og handlingsplanen om entreprenørskap i utdanningen (Kunnskapsdepartementet, 2009), finner vi lignende begrep eller begrep som innebærer noe av de samme individuelle egenskapene og holdningene, men som er pakket inn i mer allmenn språkdrakt. Her er nøkkelord samarbeidsevner, selvtillit, motivasjon og risikovillighet.

Jeg legger her følgende forståelse til grunn for individet i entreprenørskapet: «... entreprenören är en person som skapar ny verksamhet $\mathrm{i}$ konkret handling och tar eget initiativ och ansvar för sina handlingar» 
(Lundquist \& Hallberg, 2006, s. 8). Entreprenørskapsbegrepet kan ha ulike betydninger ut fra hvilken kontekst det presenteres i. I strategiplanene for entreprenørskap er det imidlertid også et fokus på prosess som jeg mener er viktig å få fram: «Entreprenørskap er en dynamisk og sosial prosess der individ, alene eller i samarbeid, identifiserer økonomiske muligheter og gjør noe med dem ved å omforme ideer til praktisk og målrettet aktivitet, det være seg i sosial, kulturell eller økonomisk sammenheng» (Kunnskapsdepartementet, Nærings- og handelsdepartementet og Kommunal- og regionaldepartementet, 2004, s. 1). Entreprenørskap blir også gjerne knyttet til nøkkelord som utforskning, utvikling, ledelse og initiativ (Bridge et al., 2009 i Åmo, 2012, s. 19). Ut fra disse definisjonene tolker jeg entreprenørskap som en grunnleggende holdning. Holdninger kobles ofte til individnivået, men vi kan også argumentere for at entreprenørskap, som en grunnleggende holdning, forutsetter et samspill mellom individ og omgivelser. Entreprenørskap kan også forstås som et organisatorisk grep som handler om kultur i lærende organisasjoner.

Det er enighet om at begrepene entreprenørskap og innovasjon henger sammen (Spilling, 2006; Åmo 2012). Et normativt utgangspunkt kan være at den entreprenørielle prosessen forutsetter en form for innovasjon (Shane, 2003 i Åmo, 2012, s. 21). Innovasjon kobles ofte til selve produktet eller handlingen, og omtales ofte som «nyvinning» eller «nyskapning», mens entreprenørskap kobles til den som står bak handlingen eller produktutviklingen/prosessutviklingen, det vil si selve «gründeren», «entreprenøren» eller «nyskaperen» (Kvangarsnes, Håvold \& Helgesen, 2016, s. 14).

Universitets- og høgskolerådet (u.å) legger til grunn for en bred forståelse av innovasjon gjennom følgende definisjon:

- Innovasjon er nye eller vesentlig forbedrede produkter, tjenester eller prosesser som tas i bruk og som gir økt verdiskaping og/eller samfunnsnytte.

- I UH-sektoren er FoU, utdanning og formidling fundamentet for innovasjon og samtidig midler for å fremme innovasjon.

- Innovasjoner er forskningsbaserte når kompetanse, kunnskap og ideer som springer ut av forskningsaktiviteten benyttes i utviklingen av forbedrede produkter, tjenester eller prosesser. 
- Innovasjoner omfatter både bidrag til å sikre økonomisk og bærekraftig vekst og konkurranseevne, og bidrag til økt samfunnsnytte i form av bedre offentlige tjenester eller et mer velfungerende samfunnssystem.

Innovasjon handler dermed om å utvikle eller forbedre noe. Dette «noe» kan være et produkt eller en prosess, men det skal gi en merverdi i form av økt verdiskapning eller oppfattet samfunnsnytte. Utdanning, undervisning og annen formidlingsaktivitet regnes både som en utskytingsrampe og en katalysator for innovasjoner. Vi kan tenke oss at undervisningen gir kunnskap om innovasjonsprosesser, men den kan også bidra tilå realisere innovasjoner.

I høgere utdanning, men også i utdanningssystemet for øvrig, ser vi at innovasjon ofte kobles til undervisningsteknologi. Innovasjonen blir her et redskap (produkt) som gjør tilrettelegging av undervisningen enklere, eller som demonstrerer nye undervisningsmåter. Det er naturlig at vi tenker på innovasjoner som oppfinnelser, men ved å begrense tenkningen om innovasjoner til teknisk innovasjon utelukker vi kanskje de mest spennende innovasjonsformene. Innovasjon i høgere utdanning kan ikke utelukkende relateres til produktperspektivet. Høgere utdanning skal bidra til læreprosesser, og dette er et felt som trenger prosessperspektivet. Tenkningen til den østerrikske sosiologen Karin Knorr-Cetina kan kaste lys over prosessperspektivet på innovasjon i universitets- og høgskolesektoren. Hun mener at vi kan gjenkjenne bestemte mønstre eller prosesser som kjennetegner nyskapende eller kreativ kunnskapsutvikling (Knorr-Cetina, 1981). Knorr-Cetina betrakter ikke kunnskap eller innovasjon som et produkt, men som et prosessuelt system hvor vi betrakter kunnskap gjennom tre dimensjoner; de relasjonelle, kulturelle og aktive sidene ved kunnskapen (ibid.). Målsettingen hennes er å vise at kunnskapsutvikling er komplekst og at kunnskap ikke kun har en innholdskomponent, men at den verken kan løsrive seg fra hvordan mennesker forvalter kunnskapen seg imellom eller strukturene som gjør at vi velger bort noe kunnskap og framhever annen kunnskap.

For å sammenfatte så langt handler entreprenørskap om å etablere ny virksomhet og utvikle denne virksomheten. Evnen til å gjøre dette er avhengig av en individuell kompetanse - en form for grunnleggende holdning. 
Selv om kompetansen er individuell, krever entreprenørskap samspill med omgivelsene. Innovasjonen er forbedringen - en nyskapning. Denne nyskapningen kan være et produkt, en tjeneste eller en prosess, men det er måten samfunnet tar innover seg merverdien av produktet, tjenesten eller prosessen på, som fører til kunnskapsutvikling eller innovasjon. Skal vi utdanne gjennom entreprenørskap og innovasjon, må vi derfor også legge til rette for at studentene oppøver og utvikler kompetanse i hvor komplekst kunnskapsutvikling er, samt synliggjøre hvordan samfunnsstrukturer og kunnskapsutvikling øver gjensidig påvirkning på hverandre.

\section{Praksisnær undervisning i lys av entreprenørskap og innovasjon}

Utgangspunktet for artikkelen er en antagelse om at satsingen på entreprenørskap og innovasjon i høgere utdanning gir en merverdi for både studentenes læreprosess og arbeids- og samfunnsliv for øvrig. Jeg er videre nysgjerrig på hvordan denne tenkningen kan kobles til praksisnær undervisning. Kan innovasjons- og entreprenørskapstenkning bidra til en mer praksisnær undervisning og/eller er det slik at en innovasjonsog entreprenørskapssatsing i UH-sektoren like gjerne har praksisnær undervisning som premiss? Dette er kanskje en høna-og-egget-problematikk, hvor begge satsinger kan bidra til hverandre?

Foranledningen til denne boka er at mange etterlyser mer praksisnær undervisning (Løvstakken, 2018), men at det ikke ser ut til være en entydig forståelse av hva praksisnærhet er, slik det er drøftet i andre kapitler. I seg selv viser begrepet praksisnær undervisning til noe som ikke nødvendigvis er praksis, men som likevel er noert praksis. I sitatet under benyttes det to begrep som jeg mener er nyttig i videre diskusjon, nemlig begrepene «læringslogikk» og «praktikkens driftslogikk»:

Praksisnær undervisning foregår på skolen. Det er ikke praksis. Det er netop undervisning nær på praksis. På skolen er der ikke tale om den samme læringslogik som i erhvervenes praksis. I praktikkens praksis lærer lærlinge og elever gennem arbejdet i praktikkens logik, præget af drift, økonomi, logistik, tempo, omgangstone, sådan som den nu er i de meget forskellige former for praktik - fra skurvogn over butik til plejehjemmet. Den praksisnære 
undervisning foregår på skolen og derfor i en anden logik - til forskel fra praktikkens driftslogik finder den sted i en læringslogik. Lærerens undervisning og elevens arbejde kan afbrydes, der kan stilles spørgsmål, gentages, gøres om. Aktiviteter og opgaver er planlagt med den hensigt at eleven skal lære af dem. Så det er vigtigt at holde fast $\mathrm{i}$, at praksisnær undervisning er noget andet end praksis. (Størner \& Sørensen 2015, s. 3)

Størner og Sørensen trekker fram at praksisnær undervisning ikke alene handler om å skape eller kopiere praksisnære driftssituasjoner, men man må også koble den praksisnære undervisningen til en læringslogikk. I denne læringslogikken forutsettes det at undervisningen forbereder til praktisk yrkesutøvelse, men man er likevel tydelig på at dette først og fremt er undervisning, og ikke praksis. Dette er et viktig skille fordi det forteller oss noe om hvem som er aktørene i praksisnær undervisning, og hvilken rolle disse aktørene skal ha. Undervisning - også den praksisnære - må høre didaktikken og pedagogene til. Den praksisnære undervisningen må forholde seg til didaktisk planlegging og - i all hovedsak - er det klasserommet, seminarets eller auditoriets rammer som gjør seg gjeldende i høgere utdanning. Undervisningen skal være målrettet, innholdet skal være egnet til å utfordre og engasjere, læreren skal være både formidler og veileder og, ikke minst, undervisningen må legge opp til en læreprosess der læringen er praksisnær og dermed også situert. Tenkningen om situert læring fokuserer på forholdet mellom læring og den sosiale situasjonen hvor læringen finner sted (Lave \& Wenger, 1991a). Den sosiale situasjonen trenger ikke være en praksissituasjon hvor vi møter «driftslogikken, men den kan være en læringssituasjon hvor erfaringer diskuteres med andre i en gitt undervisningsramme. Erfaringer kan være erfaringer fra praksisfeltet eller erfaringer fra kunnskaper vi har tilegnet oss gjennom bøker og undervisning. Vi befinner oss da i en læringslogikk.

Praksisnær undervisning er undervisning med en tydelig anvendelsesorientering og kan identifiseres som både et pedagogisk og et didaktisk prosjekt. Praksisnær undervisning handler om å skape gode forutsetninger for å gjøre undervisning til læring. For å trekke en parallell, i definisjonen av praksisnær forskning er forståelse av sammenheng en nøkkel til læring. Dette gjelder selvsagt også praksisnær undervisning. Entreprenørskapssatsingen har nettopp denne anvendelsesorienteringen. I entreprenøriell læring er læreprosesser i fokus. Læring skjer kontinuerlig, 
og prosessene er alltid koblet til den sosiale og kulturelle konteksten der den lærende (studenten) befinner seg. Det er dermed sterke bånd mellom entreprenøriell læring og sosiokulturell læringsteori, som for eksempel kontekstuell læring eller situert læring (Lundqvist \& Hallberg, 2006). I det å loere entreprenørielt lærer vi nettopp situert eller kontekstuelt. Samtidig er en situert eller kontekstuell læringstilnærming et premiss for å få til entreprenørskap og innovasjon i høgere utdanning.

Praksisnærhet i undervisningen kan forstås både som en illustrasjon/ eksemplifisering av praksis og oppløsning/dekonstruksjon av praksis. Illustrasjon av praksis kan skje ved at undervisningen etterligner den praksis som studenten skal utfolde sine kompetanser i. Oppløsning av praksis kan bety at kompliserte arbeidsprosesser i en praksisutøvelse deles opp og analyseres (Jacobsen, Jensen \& Størner, 2010). Både i forhold til illustrasjon og oppløsning/dekonstruksjon må utdanningen fokusere på å integrere teorier og kunnskaper i disse undervisningsformene. Her vil det eksemplariske prinsipp eller «best practice» kunne gi oss nyttige innfallsvinkler.

En utfordring, slik vårt utdanningssystem er organisert, er at undervisning, praksis og studentenes oppfattelse av sammenhengen mellom teori og praksis utgjør sekvensielle forløp:

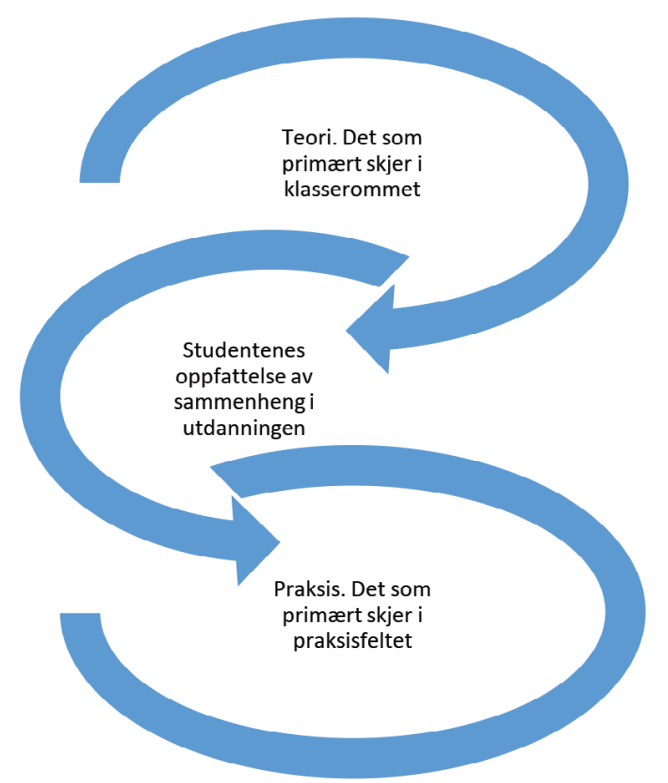

(Jacobsen, Jensen \& Størner, 2010). 
En praksisnær undervisning må derfor arbeide med å synliggjøre denne sammenhengen, for eksempel gjennom aktiviteter hvor studentene selv kan komme fram til erkjennelser gjennom refleksjon. Den praksisnære underviseren må derfor arbeide med å få frem disse erkjennelsene. Et utgangspunkt kan være å gjøre det fremmede kjent og det kjente fremmed. Det å gjøre det fremmede kjent krever at man leder studentene gjennom en prosess hvor de arbeider med å sette ord på hvilke erfaringer de faktisk har, og så søker å belyse dette med kunnskap (teori). Når vi skal gjøre det kjente fremmed, kan vi arbeide med å begrunne standpunkt, valg og handlinger overfor andre. Vi forsøker å se både handlinger, tanker og verdier utenfra. Gjennom et slikt metaperspektiv kan vi få fram både taus kunnskap og nye refleksjoner. Et mål med både entreprenørskap og innovasjon er å fremme nytenkning og risikovilje. En undervisningstilnærming hvor vi både nærmer oss og fjerner oss fra det vi mener at vi vet, vil gi oss mulighet til å utvikle nye ideer og nye tankesett. Dette gjelder også underviseren. Blir vi for trygge og vante i egen undervisningspraksis, står vi i fare for å ikke reflektere godt nok både i og over egen praksis. Vi må forsøke å vurdere egen undervisning utenfra - både i form og innhold. Slik sett kan vi argumentere for at entreprenørskap og innovasjon er nødvendige tilnærminger for å få til en praksisnær undervisning hvor vi erkjenner at både praksis og utdanning stadig er i endring.

\section{Kontekstuell læring - en tilnærming til læreprosessen i praksisnær undervisning}

En viktig oppave for undervisning i høgere utdanning er å skape sammenheng og helhet mellom teori og praksis. Praksisnær undervisning handler om å få studenter til å reflektere over kunnskaper/viten og implikasjoner det kan ha i praksisfeltet. Dette innebærer både en kognitiv-konstruktivistisk og en sosial-konstruktivistisk tilnærming. Den kognitive konstruktivismen fokuserer på hva som skjer i menneskets mentale strukturer når det lærer. Den kognitive konstruktivisten Piaget mente at kunnskap ikke var overførbar, men at den konstrueres gjennom egenaktivitet. Læring handler da om fortolkning - en intellektuell prosess der vi tenker og resonnerer over det vi iakttar eller sanser på andre måter. 
Dette innebærer at hver enkelt student vil tolke en case eller et eksempel på «best practice» ulikt, men de prosessene hver enkelt gjør i form av tanker og ressonementer, vil likevel innebære en vurdering eller en refleksjon som kan skape læring. Slik sett kan vi også argumentere for at praksis kan skje utenfor selve praksisfeltet. Studentene kan altså bruke sine tidligere kunnskaper, ferdigheter og erfaringer til å vurdere praksissituasjoner. Det som er utfordrende med denne tilnærmingen, er at det er vanskelig å måle hvordan den praksisnære undervisningen vil påvirke den enkelte studentens kompetanse i selve praksisfeltet.

Undersøkingar innan kognitiv psykologi viser at evna til å hente fram att kunnskap når vi har bruk for den er avhengig av i kva grad den er integrert med det vi har lært tidlegare, og kor godt den gjennom bruk og repetisjonar er organisert i minnet. Lærer vi i tilsvarande situasjonar som vi skal bruke kunnskapen i seinare, lagrar vi samtidig stikkord, «knaggar» eller bilde som oppstår. Dette stimulerer framhenting av den kunnskapen vi treng. (Bjørke, 1996, s. 31)

Kontekstuell læring, forstått som en tilnærming i praksisnær undervisning, viser til en kognitiv læringsprosess der premisset er at vi må nærme oss virkeligheten gjennom utdanning/opplæring for å utvikle knagger som gjør det lettere for oss å kunne hente fram igjen kunnskapen på et senere tidspunkt. Vi husker mer av abstrakt kunnskap når vi henter den fram igjen i situasjoner som tilsvarer den vi lærte dem i (Godøy, 2009). Teori og kunnskap må settes i sammenheng med handling, slik at man danner seg en situasjonsforståelse (Bjørke, 1996). Entreprenørielle undervisningsformer er egnet til å skape handling/aktivitet slik at det dannes et rom i undervisningen for å koble sammen det abstrakte med det håndfaste. Eksempler på dette kan være kafémetodikk, framtidsfortellinger, studentbedrift og ulike former for problembasert læring. De entreprenørielle undervisningsformene blir gjerne koblet til et situert læringsperspektiv (Lave \& Wenger, 1991a), og undervisning i høgere utdanning bør derfor bestrebe seg på å legge til rette for at den enkelte student opplever situasjoner hvor det utvikles slike knagger. I den neste delen av artikkelen skal vi nettopp se på hvordan vi praktisk kan innrette undervisningen slik at den danner slike rom hvor praksis og teori kobles. 


\section{Entreprenøriell undervisning og praksisnær undervisning - to sider av samme sak?}

Et eksempel på hvordan vi kan kombinere tenkningen rundt praksisnær undervisning med tenkningen om entreprenørskap, hentes fra et emne i pedagogikkutdanningen ved Høgskolen i Innlandet. Emnet «Pedagogisk utviklingsarbeid» tar for seg hvordan vi på ulike systemnivå (individ, gruppe, organisasjon) kan arbeide for å gjennomføre og vurdere pedagogisk utviklingsarbeid. I emnet ser vi på teorier, forskning og praktiske erfaringer med pedagogisk utviklingsarbeid i ulike virksomheter. Felles for virksomhetene som trekkes fram, er at det er fokus på samhandling, veiledning og endringsarbeid for å fremme og forbedre pedagogisk praksis. Et viktig læringsmål i emnet er at studentene skal ha kjennskap til de mest aktuelle strategiene for å planlegge, gjennomføre og evaluere pedagogisk utviklingsarbeid.

Studentene får et arbeidskrav hvor gruppa skal jobbe med en praktisk case, det vil si at gruppa skal beskrive og vurdere et reelt utviklingsarbeid i en pedagogiske virksomhet. Etter nærmere avtale mellom studentgruppa, studiet og en virksomhet skal studentene gjøre seg kjent med et pedagogisk utviklingsarbeid i en praksis hvor pedagogisk arbeid inngår på en eller annen måte. Eksempler på praksiser kan være et skoleutviklingsprosjekt for en hel skole, utvikling av et område innenfor en skole som for eksempel lese- og skriveopplæring, utviklingsarbeid i en barnehage, hvordan Røde Kors setter i gang leksehjelp, hvordan Frivillighetssentralen organiserer pensjonister, utvikling av et fritidstilbud for barn og unge etc. Gruppa skal møte, samtale med, intervjue og observere folk i praksis og skrive notater fra dette samt studere relevante dokumenter knyttet til arbeidet. Studentene skal også knytte arbeidet til teoristoff fra pensum der dette er relevant. Arbeidet skal dokumenteres gjennom innlevering av rapport på beskrivelse og vurderinger fra arbeidet. Dette er et arbeidskrav som settes i gang hver høst. De pedagogiske virksomhetene i lokalmiljøet er positive til å ta imot studentene og bruker tid på å møte dem og dele av sine erfaringer. Studentene får på sin side erfare at fagstoff om pedagogisk utviklingsarbeid ikke nødvendigvis er slik pedagogisk utviklingsarbeid praktiseres. Og det er nettopp at de får erfare - og ikke bare loere 
om - som er sentralt. Når studentene får samle egen kunnskap gjennom intervju, observasjoner og rapporter, må de se denne kunnskapsbeholdningen i lys av - eller kanskje også i motsetning til - den kunnskapsoverføringen vi har som mål å få til i auditorier og seminarrom.

En hensikt med at studentene har et arbeidskrav som krever at de gjør intervju og observasjoner ute i pedagogiske virksomheter, er at det legger til rette for at de hører ulike aktører sin stemme. Dette skjer utenfor auditoriets rammer. Henri Lipmanowicz og Keith McCandless tenkning rundt Liberating Structures kan gi en nyttig innramming for den didaktiske tenkningen i emnet og kan også kaste lys over de intenderte læreprosessene ved selve arbeidskravet. Liberating Structures lar seg oversette som noe sånt som «frigjørende strukturer» og består av flere modeller for å få fram erfaringsdeling og bevisstgjøring i arbeidslivet med hensikt å bedre praksis (Lipmanowicz \& McCandless, 2013). Tanken er at vi ofte ikke evner å være innovative eller kreative fordi det nettopp er strukturene rundt oss, for eksempel rolleforventninger eller organisasjonskultur, som lager rammer rundt oss i det daglige. Disse rammene er ofte nødvendige for at vi skal arbeide sammen i (praksis)fellesskap, men de kan også begrense mulighetene vi har til å løse problemer eller til å utvikle praksisen vår. Utgangspunktet er at man ved å tydeligere definere problem og utfordringer i en arbeidssituasjon også kan oppdage og konkretisere nye løsninger på det som ikke fungerer optimalt. Liberating Structures viser til flere modeller eller tilnærminger for å sette i gang en prosess hvor vi prøver å løsrive oss fra hvordan vi både ser på vår egen praksis og den organisasjonen vi arbeider i (ibid.). Hvis vi har som premiss at innovasjon handler om å utvikle noe, og at entreprenørskap innebærer egenskaper som samarbeidsevner, selvtillit, motivasjon og risikovillighet, vil det være nødvendig at undervisning i høgere utdanning legger til rette for at studentene evner å frigjøre seg fra strukturene rundt dem. Studentene er omgitt av strukturer hvor undervisningens innhold er bestemt av andre, samtidig som at fagstoffet de lærer, ikke nødvendigvis kan overføres direkte til praksissituasjoner. Arbeidslivet endres stadig, og vi snakker om kunnskap som ferskvare. Slik sett er Liberating Structures tilnærminger som bygger på å utvikle kreative og innovative løsninger, og som kan være egnet til å gi praksisnær undervisning. 
Arbeidskravet er i seg selv verken særlig banebrytende eller særegent. Poenget er mer at vi ved å bevisstgjøre oss egen undervisningspraksis nokså enkelt kan gjøre grep hvor vi skaper kontekster der studenter kan erfare, øve holdninger og tilegne seg nye kunnskaper og ferdigheter. Jeg vil argumentere for at arbeidskravet er både entreprenørielt og praksisnært - og at det dermed har utgangspunkt i en situert og kontekstuell læringstilnærming. Etienne Wenger og Jean Lave presenterte begrepet «situert læring» på begynnelsen av 1990-tallet (Lave \& Wenger, 1991b). Teorien om situert læring tar utgangspunkt i at læring må ses i sammenheng med den konteksten den anvendes i, og det er slikt sett en sosial læringsteori. Det kan likevel være verdt å merke seg at Wenger og Lave selv ikke omtaler situert læring som en læringsteori, men heller et analyseverktøy for å forstå læring (Lave \& Wenger, 1991b; Rundberg, 2009). Å nærme seg situert læring som nettopp et analyseverktøy framfor en teori vil kunne være nyttig for å omsette entreprenørskap og innovasjon til en konkret lærings- og danningsprosess. Situert læring foregår knyttet til en situasjon eller kontekst. Konteksten er historisk, samfunnsmessig og kulturelt bestemt. I eksemplet er konteksten en praksisvirkelighet hvor pedagogikkstudentene får innblikk og deltakelse i hva utviklingsarbeid består av i pedagogiske virksomheter. Studentene får også erfare at utviklingsarbeid ikke alltid er etter boka. Utviklingsarbeidene er kanskje ikke forankret i alle deler av en organisasjon eller de oppfattes mer som et pålegg fra skoleeier enn et reelt behov for endring.

Lave og Wenger viser til legitim perifer deltakelse for å forklare hvordan vi kan forstå hva som skjer i praksissituasjoner hvor læring finner sted (Hansen, 2000). I oppstarten er det naturlig at man befinner seg $\mathrm{i}$ randsonen av praksissituasjonen, man er altså en perifer deltaker. Etter hvert vil man gradvis nærme seg praksisens kjerne og bli en etablert del av et praksisfellesskap. Men en slik forståelse av situert læring og praksisfellesskap innebærer en praksisnær læreprosess som ikke uten videre kan kobles til undervisning i seminarrom og auditorier i høgere utdanning. Hansen (2000) argumenterer likevel for at situert læring også er et utgangspunkt for den læring som foregår i klasserommet. I vårt eksempel blir ikke studentene en etablert del av et praksisfellesskap ute i de 
pedagogiske virksomhetene de oppsøker, men de er legitime perifere deltakere som pedagogikkstudenter. Erfaringene studentene gjør seg, setter dem i stand til å nærme seg en kjerne - ikke kjernen på arbeidsplassen, men kjernen i studiet. Jeg vil derfor argumentere for at begrepet legitim deltakelse og prosessen fra perifer til fullverdig deltakelse også kan brukes som et analyseverktøy for klasseromspraksis (Hansen, 200o, s. 222). Her kan vi betrakte en studentgruppe eller en klasse som et praksisfellesskap. Gjennom å være en aktiv deltaker i gruppa eller klassen beveger man seg inn mot kjernen i praksisfellesskapet. I klasserommet kan denne kjernen være å dele kunnskap som er tilgjengelig om et fag med hverandre, og man deler også en oppfattelse av hvordan dette faget skal forstås eller operasjonaliseres, for eksempel hvordan man løser en ligning eller hvordan man setter i gang et prosjektarbeid. Bevegelsen fra å være en perifer deltaker til en sentral deltaker er ikke alltid like tydelig.

Kontekstene hvor læring foregår, kalte Wenger «Communities of Practice» eller "praksisfellesskap» (Wenger, 1998). Praksisfellesskapene er en slags ramme hvor kollegaer tar hverandres kompetanse i bruk, og hvor man motiverer hverandre til videre vekst. For å få til disse praksisfellesskapene kreves det en læringskultur hvor man anerkjenner nødvendighet av sosialt fellesskap og nødvendigheten av å tenke læring i et helhetlig livslangt perspektiv. Praksisfellesskapene må forholde seg til en ramme hvor problemområder er bestemt og kunnskap definert, men praksisfellesskapene har frihet til å definere egen rolle og styringsform (Rundberg, 2009, s. 56). De skal være selvgående og autonome, men de kan støttes og veiledes. Gruppene må også oppleve at de er en del av en organisasjon og at de er viktige for dens videre utvikling. Å være en del av en organisasjon er en naturlig ramme når vi tenker situert læring som et verktøy for læring og kompetanseutvikling på arbeidsplassen. I vår kontekst kan organisasjonen både være høgskolen, studiet eller faget. Vi kan tenke oss praksisfellesskap bestående av studenter som arbeider med temaer for å utvikle ny kunnskap. De kommer med individuelle identiteter, erfaringer og kunnskapsfortolkninger og må øve disse sammen i et fellesskap med formål om å heve kompetansen eller utvikle ny kunnskap. Denne øvelsen er ikke ny i 
utdanningssammenheng, hvor troen på samarbeidslæring og gruppelæring har blitt fremmet i flere læreplaner, og hvor gruppeaktivitet tilsynelatende er en etablert praksis på de fleste universitets- og høgskolestudier. Er det så noe som skiller gruppelæring og situert læring gjennom praksisfellesskapene? For det første handler praksisfellesskapene om en bevisstgjøring av at læring er en kontinuerlig og dynamisk prosess. Fokuset kan ikke være et endelig mål. Dette fordrer at praksisfellesskapet/studentgruppene ikke arbeider ensidig mot å nå en beskrivelse av et læringsutbytte, men at selve interaksjonen og erfaringsdelingen i en gruppe knyttet til en kontekst, for eksempel et tema $i$ et fag eller en praksisanvendelse av faget, representerer en verdifull læreprosess. Denne læringen både fordrer og tilrettelegger for selvstendiggjøring og refleksivitet av et faglig innhold, samtidig som den forutsetter bevisstgjøring om dens egen vesen. En slik læreprosess representer dannelsen av det entreprenørskapsutdanning handler om: holdninger og egenskaper som nytenkning, kreativitet, selvtillit, selvstendighet og risikovilje (Kunnskapsdepartementet, 2009).

\section{Avslutning}

Norsk policy for innovasjon i UH-sektoren legger føringer på at både fagansatte og studenter skal ha kjennskap til hva entreprenørskap og innovasjon i utdanning innebærer for respektive fagfelt. Hva man legger i begrepene «innovasjon» og «entreprenørskap», vil selvsagt variere ut fra faglig ståsted, og vil nødvendigvis også legge føringer på tilnærmingen til en undervisning som skal fremme slik kompetanse. Nettopp dette mangfoldet $\mathrm{i}$ både bakgrunn og tilnærming vil kunne gi grobunn for diskusjoner om hvordan entreprenørskap og innovasjon skal utvikles og forankres i både forskning og undervisning i høgere utdanning og slik sett prege utdanningsløpene. Både forståelsen av innovasjon og entreprenørskap - og tenkningen rundt - krever en handlingsrettet, praksisnær tilnærming. Slik sett er entreprenørskaps- og innovasjonssatsingen også en satsing på praksisnær undervisning. Høgere utdanning kan ikke utelukkende foregå i det praksisfeltet det skal utdanne til, men gjennom å legge til rette for undervisningsformer som stimulerer 
både kontekstuelle og situerte læreprosesser, kan vi bidra til å utvikle kompetanser som gir kreativitet, innovasjon og nyskapning. Utdanningssektoren har en utfordring i å vise bredden i hva entreprenørskap og innovasjon er, og kan bety, for forbedring av særlig offentlige tjenester i samfunnet. Entreprenørskap kan ikke være gründeren, og innovasjon kan ikke være oppfinnelsen, om vi skal lykkes med å få til en forståelse og en forankring av entreprenørskap og innovasjon i høgere utdanning. Vi må ha et bredere perspektiv hvor vi fokuserer på entreprenørskap som holdning og innovasjon som prosess. Artikkelens utgangspunktet for å forstå entreprenøren har vært følgende «(...) entreprenören är en person som skapar ny verksamhet i konkret handling och tar eget initiativ och ansvar för sina handlingar» (Lundquist \& Hallberg, 2006, s. 8). Hvis vi tenker oss studenten som en slik entreprenør, kan vi møte denne utfordringen. Universitets- og høgskolesektoren kan nærme seg regjeringsstrategiene for entreprenørskapsutdanningen gjennom å tilrettelegge for at studentene har kompetanse som entreprenører slik Lundquist og Hallberg forstår det. En slik tilrettelegging vil nødvendigvis kreve at undervisningen er både innovativ og praksisnær.

Utdanningssystemets særegenhet og utfordring er at den ofte skal kvalifisere til en praksis som ikke er dens egen. Undervisningen i klasserommet skal dermed kvalifisere til noe som ligger utenfor selve skolen, men som begrunnes i krav fra arbeids- og samfunnsliv. Fagene i seg selv utvikles ikke utelukkende i skolen eller i klasserommet, men påvirkes for eksempel av vitenskapsfag og politiske føringer. Det samme resonnement kan anvendes på studier. Her er studiet kanskje tettere på den vitenskapelige utviklingen, men man skal like fullt kvalifisere til et praksisfelt som ikke er ens eget. Disse utfordringene kan lett føre til en for instrumentalistisk tilnærming til læring og undervisning. Ved å se på skolens eller studienes kjerner kan man skape kontekster for å fremme situert læring. Her vil praksisfellesskapene kunne være grupper med studenter, lærere og veiledere som sammen arbeider med å utvikle ny forståelse. På den måten kan vi kanskje si at kunnskapsutvikling gjennom entreprenørskap og innovasjoner ikke skjer utenfor faget eller studiet, men midt i det? 


\section{Litteratur}

Bjørke, G. (1996). Problembasert loering - ein praksisnor studiemodell. Oslo: Tano Aschehoug.

Bremnes, H., Bergem, B. G. \& Nesset, E. (2016). Is there coherence between policy formulation and public funding of innovation projects? I M. Kvangarsnes, J. I. Håvold \& Ø. Helgesen (Red.), Innovasjon og entreprenørskap. Oslo: Universitetsforlaget.

Brown, L. \& Osborne, S. P. (2013). Risk and innovation. Public Management Review, 15(2), 186-208. https://doi.org/10.1080/14719037.2012.707681

Drucker, P. F. (1985) Innovation and entrereneurship. Practices and principles. New York: Harper \& Row.

Duckworth, E. (1964). Piaget rediscovered. Journal of Research in Science Teaching, 2(3), 172-175.

Elter, F. \& Myhre, D. (2014). Forskning som grunnlag for tjenesteinnovasjon - en ny tilnærming. Magma, 14(8), 72-81.

Foster, M. \& Kaplan, S. (2001). Creative destruction. Cambridge, MA: Perseus.

Godøy, J. (2009). Forberedelse til å takle hverdagen? Kontekstuell loring og studentaktive arbeidsformer som bidrag til utvikling av loereres relasjonelle og sosiale kompetanse (Mastergradsavhandling). Oslo: Universitet i Oslo. Hentet 6. januar 2019 fra https://www.duo.uio.no/handle/10852/31156

Gornitzka, Å. \& Olsen, J. P. (2006). Europeiske endringsprosesser og høgere utdanningsinstitusjoner. Tidsskrift for samfunnsforskning, 47(2), 259-274.

Hansen, G. K. (2000). Situert læring i klasserommet. I K. Illeris (Red.), Tekster om loering. Fredriksberg: Roskilde Universitetsforlag.

Jacobsen, K., Jensen, L. B. \& Størner, T. (2010). Den praksisnoere undervisning og den fagstolte elev $i$ de merkantile, social- og sundheds- og landbrugs-uddannelserne. UC Metropol, NCE.

Kallerud, E. (2006). Norden som forsknings- og innovasjonspolitisk foregangsregion med fokus på Danmark og Norge. Arbeidsnotat 50/2006, Oslo: NIFU STEP.

Knorr-Cetina, K. D. (1981). The manufacture of knowledge - an essay on the constructivist and contextual nature of science. New York: Pergamon Press.

Kommunenes Sentralforbund. (u. å.). Innovasjon og utdanning. Hentet 6. januar $2019 \mathrm{fra} \mathrm{http://www.ks.no/fagomrader/utvikling/innovasjon/fremtidens-skole/}$

Kunnskapsdepartementet. (2017.) Kultur for kvalitet i høgere utdanning, (Meld St nr. 16 (2016-2017)) Hentet 6. januar 2019 fra https://www.regjeringen.no/no/ dokumenter/meld.-st.-16-20162017/id2536007/sec

Kunnskapsdepartementet, Nærings- og handelsdepartementet og Kommunal- og regionaldepartementet. (2009). Handlingsplan - Entreprenørskap i utdanningen fra grunnskole til høgere utdanning 2009-2014. Hentet 19. september 2018 fra 
http://www.regjeringen.no/upload/KD/Vedlegg/Grunnskole/Strategiplaner/ handlingsplanen\%2oendelig\%2oversjon\%2oentreprenørskap.pdf

Kunnskapsdepartementet. (2006).... og ingen sto igjen. Tidlig innsats for livslang loering. (St.meld nr. 16 (2006-2007). Hentet 6. september 2018 fra www.regjeringen.no: https://www.regjeringen.no/no/dokumenter/stmeldnr-16-2006-2007-/id441395/

Kunnskapsdepartementet, Nærings- og handelsepartementet og Kommunalog regionaldepartementet. (2004). Strategiplan - Se mulighetene og gjør noe med dem! Strategi for entreprenørskap i utdanningen 2004-2008. Hentet 28. oktober 2018 fra http://www.regjeringen.no/upload/KD/Vedlegg/Grunnskole/ Strategiplaner/75561_entrepenorskap_strategi.pdf

Kvangarsnes, M., Håvold, J. I. \& Helgesen Ø. (2016). Innovasjon og entreprenørskap mellom fjord og fjell. I M. Kvangarsnes, J. I. Håvold og Ø. Helgesen (Red.), Innovasjon og entreprenørskap. Oslo: Universitetsforlaget.

Lave, J. \& Wenger, E. (1991a). Situated learning: Legitimate peripheral participation. Cambridge: Cambridge University Press.

Lave, J. \& Wenger, E. (1991b). Legitim perifer deltakelse. I K. Illeris (Red.), Tekster om loering. Fredriksberg: Roskilde Universitetsforlag.

Lipmanowicz, H. \& McCandless, K. (2013). The surprising power of liberating structures: Simple rules to unleash a culture of innovation. Liberating Structures Press. Creative Commons.

Lundquist, Å. F. \& Hallberg, P.-G. (2006). Företagsamt lärande i teori og praktikk: Handbok og idématerial för lärare og elever. Umeå: Länsstyrelsen Västerbotten.

Løvstakken, T. (2018). Vil ha mer praksisnær undervisning. Khrono. Hentet 2o. april 2018 fra https://khrono.no/tekna-utdanning-lovstakken/vil-ha-mer-praksisnaerundervisning/220023

Nærings- og handelsdepartementet. (2008). Et nyskapende og borekraftig Norge, (St meld nr. 7 (2008-2009)) Hentet 6. september 2018 fra https://www. regjeringen.no/contentassets/f69oda32d4da4ao782c49b16e12eo552/no/pdfs/ stm20082009000700odddpdfs.pdf

Osborne, S. P. \& Brown, L. (2011). Innovation, public policy and public services delivery in the UK. The word that would be king? Public Administration, 89(4), 1335-1350. https://doi.org/10.1111/j.1467-9299.2011.01932.x

Pedersen, A. S. (2006). Den skabende institusjon og innovation i professionsuddannelsen. I K. Skogen, \& J. Sjøvoll (Red.), Pedagogisk entreprenørskap - Innovasjon og kreativitet $i$ skoler i Norden, Trondheim: Tapir Akademisk Forlag.

Roberts, N. C. \& King, P. J. (1996). Transforming public policy: Dynamics of policy entrepreneurship and innovation. San Francisco, CA: Jossey-Bass Publishers.

Rundberg, M. (2009). Wengers praksisfellesskap. Bedre skole, 3, 54-59. 
Skogen, K. \& Homberg, J. B. (2005). Elevtilpasset opplaring - en innovasjonstilnorming. Oslo: Universitetsforlaget.

Spilling, O. R. (2006). Entreprenørskap på norsk (2 utgave). Bergen: Fagbokforlaget.

Størner, T. \& Sørensen, K. H. (2015). Praksisnær undervisning i erhvervsuddannelserne. Inspark 5. Danmark: EPUC - Erhvervspædagogisk udviklingscenter. Hentet 29. oktober 2018 fra http://epuc.dk/wp-content/ uploads/2015/11/Praksisn\%C3\%A6rhed-indspark-5.pdf

Säljø, R. (2009). The entrepreneurial side of learning and knowing: Networked societies and the emergence of new epistemic practices. I K. Skogen \& J. Sjøvoll (Red.). Pedagogisk entreprenørskap - innovasjon og kreativitet i skoler i Norden. Trondheim: Tapir Akademisk Forlag.

Thong, J. Y. L. (1999). An integrated model of information systems adopting in small businesses. Journal of Management Information Systems, 15(4), 187-215.

Universitets- og høgskolerådet. (2013). Eureka! Om innovasjon i UH-sektorens kunnskapskretsløp. Hentet 28. oktober 2018 fra http://www.uhr.no/ressurser/ temasider/innovasjon/innovasjon_-_uhrs_inspirasjonsnotat

Universitets- og høgskolerådet, u.å. Om innovasjon. Hentet 28. oktober 2018 fra http://www.uhr.no/aktuelt_fra_uhr/eureka_om_innovasjon_i_uh-sektorens_ kunnskapskretslop

Wenger, E. (1998). En social teori om læring. I K. Illeris (Red.) (200o), Tekster om loering. Fredriksberg: Roskilde Universitetsforlag AS.

Åmo, B. W. (2012). Entreprenørskapsutdanning i endring. Oslo: Cappelen Damm Akademisk. 



\section{Om forfatterne}

Inger Marie Bakke er førsteamanuensis i pedagogikk ved Seksjon for veiledning, Institutt for sosialvitenskap og veiledning, Høgskolen i Innlandet. Hun underviser i tematikk knyttet til kommunikasjon i profesjonelle kontekster og til veiledning/karriereveiledning. Hun forsker på utvikling av egen relasjonskompetanse: Aubert, A.-M. \& Bakke, I. M. (2018). Utvikling av relasjonskompetanse. Nøkler til forståelse og rom for loering. 2. utg. (ISBN 978-82-05-50075-4) og karriereveiledning: Bakke, I. M., Barham, L. \& Plant, P. (2020). As Time Goes By: Geronto Guidance. I E. H. Haug, T. Hooley, J. Kettunen \& R. Thomsen (Red.), Career Guidance in the Nordic Countries (in press).

Håkon Glommen Eriksen er filosof og jurist og førstelektor ved Institutt for sosialvitenskap og veiledning, Høgskolen i Innlandet. Han underviser bl.a. i temaer som etikk, relasjonskompetanse og dannelse. Hans forskningsinteresse ligger innenfor selvfortolking og verdier: Eriksen, H. G. (2015). Hvem er mennesket og hva er veiledning? Noen innspill fra psykologen Carl Rogers og filosofen Charles Taylor. I Veivalg. Årbok for veiledernettverket i Innlandet.

Egil Eide er tilsett som dosent i pedagogikk og dosent i helsefag ved praktisk-pedagogisk utdanning - yrkesfag, Høgskulen på Vestlandet, campus Bergen, Fakultet for lærarutdanning, kultur og idrett, og Institutt for Pedagogikk, religion og samfunnsfag. Egil Eide er leder av forskargruppen SKILLSinVET (Identifying Skills for Relevant and Meaningful Teaching for Learning in Vocational Teacher Education and Training. Curricula and Practice in Dynamic Interplay) og har de siste årene særlig forsket på 21 st. century skills i yrkesfagene, relevant og meningsfull undervisning for læring i yrkesfag og studentaktive læringsformer. Han har mange års erfaring som leder, forsker og underviser i høyere utdanning i sykepleievitenskap, pedagogikk og yrkespedagogikk. 
Trine Fossland er professor på Ressurssenter for undervisning, læring og teknologi, RESULT, UiT Norges arktiske universitet. Fossland har vært medlem av flere nasjonale ekspertgrupper om kvalitet i høyere utdanning og vært nestleder i det nasjonale nettverket for universitet- og høyskolepedagogikk i flere perioder. Hovedinteressene forskningsmessig er primært rettet mot høyere utdanning og feltene bruk av digital teknologi, pedagogisk innovasjon, utdanningsledelse og forskningsveiledning. Hun har skrevet en rekke artikler, bøker og bokkapitler innen disse områdene som for eksempel: Fossland, T., Mathiassen, H. M. \& Solberg, M. (2015), Academic Bildung in net based higher education: moving beyond Learning (London: Routledge) og Digitale loringsformer i høyere utdanning (2015, Universitetsforlaget).

Grete Salicath Halvorsen er førsteamanuensis ved Høgskolen Innlandet, Institutt for sosialvitenskap og veiledning. Hun er utdannet sosionom og har praksis fra blant annet kriminalomsorg og voksenpsykiatri. Hun avla sin doktorgrad i 2011 ved Universitetet i Nordland, Senter for praktisk kunnskap. Avhandling PhD: Relasjonen mellom hjelper og hjelpesøkende. En studie i forståelsens og anerkjennelsens betingelser og muligheter. Artikler: Relasjonen mellom hjelper og hjelpesøkende: Hva gjør den virksom? (Nordisk tidsskrift for helseforskning, nr. 1, 2008), Anerkjennelsens betydning for en hjelpende relasjon: Om selvforståelse og andreforståelse (Klinisk sygepleje nr. 4, 2009) Forståelsens konstitusjonelle betingelser (Refleksion i praksis. Skriftserie Aarhus Universitet Nr. 6).

Gisle Heimly er tilsatt som høgskulelektor ved praktisk-pedagogisk utdanning på Høgskulen på Vestlandet, campus Bergen, Fakultet for lærarutdanning, kultur og idrett og institutt for Pedagogikk, religion og samfunnsfag. Han er utdannet cand.polit. med hovedfag i pedagogikk/ skoleforskning. Han har arbeid som lærer og rektor i grunnskulen og har nærmere 20 års erfaring som lærerutdanner. Forskingsinteressen hans er utdanningskvalitet og pedagogisk filosofi. Medlem i forskargruppa SKILLSinVET (Identifying Skills for Relevant and Meaningful Teaching for Learning in Vocational Teacher Education and Training. Curricula and Practice in Dynamic Interplay). 
Thomas de Lange er førsteamanuensis ved Institutt for pedagogikk på Universitetet i Oslo. Hans forskningsfelt er primært rettet mot høyere utdanning med særlig fokus på undervisning, veiledning og teknologibruk i læring. Han har i en årrekke undervist innen ulike universitetspedagogiske temaområder med vekt på undervisning og veiledning $\mathrm{i}$ profesjonsutdanninger, og har vært aktivt involvert $\mathrm{i}$ arbeid med utvikling av studiekvalitet innen odontologi- og medisinerutdanning. de Lange har tidligere vært koordinator for faglig enhet for universitetspedagogikk ved $\mathrm{UiO}$ og er for tiden nestleder i nasjonalt nettverk for universitets og høyskolepedagogikk.

Monika Nerland er professor ved Institutt for pedagogikk, Universitetet i Oslo. Hun er leder for forskergruppen HEDWORK som studerer kunnskapsutvikling, ledelse og læring i høyere utdanning og arbeidsliv. Hennes publikasjoner inkluderer bøkene Reconfiguring knowledge in higher education (Springer, 2018, samredigert med Peter Maassen og Lyn Yates) og Reconceptualising professional learning. Sociomaterial knowledges, practices and responsibilities (Routledge, 2014, samredigert med Tara Fenwick).

Yngve Nordkvelle er professor i pedagogikk ved Høgskolen i Innlandet og leder seksjonen for universitets-og høgskolepedagogikk. Han har vært redaktør av tidsskriftene Uniped og Seminar.net, og har i de seneste årene skrevet om simulering i sykepleieutdanning, om film og tv-fagenes studiefagsdidaktikk, om lærebøker og om målstyringsfenomenet i norsk utdanningspolitikk. Siste bok: Digital Storytelling in Higher Education, med Grete Jamissen, Pip Hardy og Heather Pleasants (Red.) (2017) Palgrave Macmillan.

Lene Nyhus er førsteamanuensis i pedagogikk ved Institutt for pedagogikk, Høgskolen i Innlandet. Hun underviser i pedagogikk og i kommunikasjon og er særlig opptatt av pedagogiske grunnlagsproblem, teori og metateori, koblet mot praksis, skole- og barnehageutvikling. Nyhus skrev doktoravhandlingen (Nyhus, 2012), Det kommunikative grunnlaget $i$ skoleutvikling. Et metaprosjekt. (ISBN: 978828440882). 
Anne Røisehagen er høgskolelektor ved Institutt for pedagogikk, Høgskolen i Innlandet. Hun underviser i pedagogikk, og har spesielt vært opptatt av å utvikle studentaktive undervisningsformer og av relasjonens betydning i undervisning og i møte med studenter. Hun har i de senere år forsket på seminar som læringsarena i høgere utdanning. Anne Røisehagen har master i pedagogikk med fokus på «Kvalitet i feedback som formativ vurdering i høgere utdanning», en teoretisk og empirisk analyse og forståelse av kommunikasjonen og relasjonens betydning i feedback som formativ vurdering med sentrale implikasjoner for studenters læringsutbytte.

Randi Hojem Røthe har undervist i pedagogikk og vært studieleder ved Institutt for pedagogikk, Høgskolen i Innlandet. Hun har spesielt vært opptatt av utvikling av godt læringsmiljø og hvordan vi tar imot nye studenter. Røthe har master i pedagogikk med fokus på skoleledelse og hvordan Rektorskolen brukte ny kunnskap om ledelse, læring og motivasjon. Hun har forsket på skoleledelse: Delrapport 2 fra evaluering av den nasjonale rektorutdanningen (ISBN 978-82-7218-871-8) og Læringsmiljø: Hvem er studenten? (ISBN 978-82-7184-410-3) og Utvikling av læringsmiljø med fokus på relasjonsbygging (ISBN 978-82-7184-382-3).

Eli Skjeseth er høgskolelektor i veiledning ved Høgskolen i Innlandet, Institutt for sosialvitenskap og veiledning. Hun underviser i videreutdanninger i veiledning i Arbeids- og velferdsforvaltingene (NAV), tverrfaglig veiledning og karriereveiledning. Skjeseth har hovedfag i yrkespedagogikk med læring på arbeidsplassen og ledelse av læreprosesser som spesialfelt. Hun forsker på kommunikasjon, tverrfaglig samarbeid og tverrsektoriell ledelse: Skjeseth, E. (2019). Tverrsektoriell ledelse i forsøk med NAV-veiledere i videregående skole 2013-2018. Skriftserien: Vol. 7: Høgskolen i Innlandet.

Odd Rune Stalheim er utdannet allmennlærer og har master i pedagogikk fra Høgskolen i Lillehammer. For tiden er han engasjert som ph.d. kandidat ved ph.d. program innen offentlig og privat tjenesteinnovasjon (INTOP), Høgskolen i Lillehammer. Hans forskning fokuserer på kvalitet og innovasjon i høyere utdanning, og ser nærmere på hvordan studentene 
opplever forholdet mellom teori og praksis. Prosjektet tar også sikte på å identifisere og undersøke faktorer som påvirker utviklingen av profesjonell kompetanse i norsk høyere utdanning. Stalheim var tilknyttet det nasjonale prosjektet «Quality in Norwegian Higher Eduaction». Han har publisert både artikler og bokkapitel både nasjonalt og internasjonalt, for eksempel: Stalheim, O. R., \& Nordkvelle, Y. (2018). I Saved the Patient: Simulation and Self-Efficacy in Health Education. In Self-Efficacy in Instructional Technology Contexts (s. 75-88). Springer, Cham og Stalheim, O. R. Hurtigpraksis-ein entreprenøriell respons på opplevd yrkesdistanse. Uniped, 41(01), 29-41.

Njål Vidar Traavik er tilsett som høgskulelektor ved praktisk-pedagogisk utdanning for yrkesfag på Høgskulen på Vestlandet, campus Bergen, ved Fakultet for lærarutdanning, kultur og idrett og Institutt for Pedagogikk, religion og samfunnsfag. Han er utdanna cand.polit. med hovudfag i pedagogikk. Traavik har arbeid som lektor og inspektør i vidaregåande skule. Dei siste 15 åra har han arbeid med undervising og veiledning av lærarstudentar (PPU- yrkesfag og allmennfag, allmennlærarutdanninga, lektorutdanninga og praktisk-estetisk faglærarutdanning) og er fagansvarleg innafor etter- og vidareutdanningar, samt eksterne kurs. Hans forskingsinteresse er utdanningskvalitet, med tema som studentaktive læringsformer, praksis i utdanningane og undervisingskultur. Han har bl. a.publisert artiklar med tittel; Uteskole, en arena for GLSM-faget og Forholdet mellom teori og praksis i pedagogikkfaget. Han er medlem i forskargruppa SKILLSinVET (Identifying Skills for Relevant and Meaningful Teaching for Learning in Vocational Teacher Education and Training. Curricula and Practice in Dynamic Interplay).

Ingrid Tvete er høgskolelektor ved Institutt for pedagogikk ved Høgskolen i Innlandet hvor hun underviser pedagogikkstudenter i veiledning og pedagogisk utviklingsarbeid. Tvete forsker på området entreprenørskap i utdanning. Hun har bidratt til rapporten UHRs inspirasjonsnotat: «Eureka! Om innovasjon i UH-sektorens kunnskapskretsløp» (http:// www.uhr.no/ressurser/temasider/innovasjon/innovasjon_-_uhrs_inspirasjonsnotat). Tvete har tidligere forsket på holdninger i norske lærebøker 
knyttet til nord/sør-spørsmål, menneskerettigheter og mangfold: Nordkvelle, Y. \& Tvete, I., «Verdensborgerskap, læreplanutvikling og lærebøker» i Nordkvelle, Haugsbakk \& Nyhus (2012), Pedagogisk utvikling - veier og omveier til en god skole (s. 206-225), Cappelen Damm Akademisk. ISBN 978-82-02-39864-4.

Anne Line Wittek er professor ved Universitetet i Oslo, Institutt for pedagogikk. Hun forsker på læring og undervisning i høyere utdanning og har publisert en rekke arbeider om forholdet mellom pedagogiske verktøy og studenters læring, kvalitet i undervisning og profesjonell utvikling. Hun arbeider innenfor en sosio-kulturell dialogisk forståelse av hvordan mening skapes, og fokuserer på betydningen av kultur og historisk utviklede verktøy som medier i læring. Hennes seneste publikasjoner inkluderer: de Lange, Thomas \& Wittek, Anne Line (2018). Creating shared spaces: developing teaching through peer supervision. Mind, Culture, and Activity. https://doi.org/10.1080/10749039.2018.1544645, Prøitz, Tine Sophie \& Wittek, Anne Line (2019). New Directions in Doctoral Programmes: Bridging Tensions between Theory and Practice? Teaching in Higher Education. https://doi.org/10.1080/13562517.2019.1577813, Wittek, A. L. (2016). Processes of Writing as Mediational Tool in Higher Education. Scandinavian Journal of Educational Research. https://doi.org/10.1080/oo 313831.2016.1258664.

Anne-Lise With er førstelektor ved AMEK - fakultet for Audiovisuelle medier og kreativ teknologi, faggruppen Film- og fjernsynsvitenskap, Høgskolen i Innlandet. Hun underviser i filmvitenskap og kultursosiologi. With har hovedfag i filmvitenskap fra NTNU med temaet kvalitetsfilm og kinopolitikk, samt Karriereveiledning (30 stp) fra HiL. De siste årene har hun vært spesielt opptatt av veiledning som tilbud i overgangen fra videregående skole til studier, og har forsket på ForVei - forberedende veiledning for første års studenter: With, A. L. (2019). Studentforberedende veiledning - et spørsmål om motivasjon, mestring og studiekvalitet. Skriftserien 1 - 2019: Hinn. 